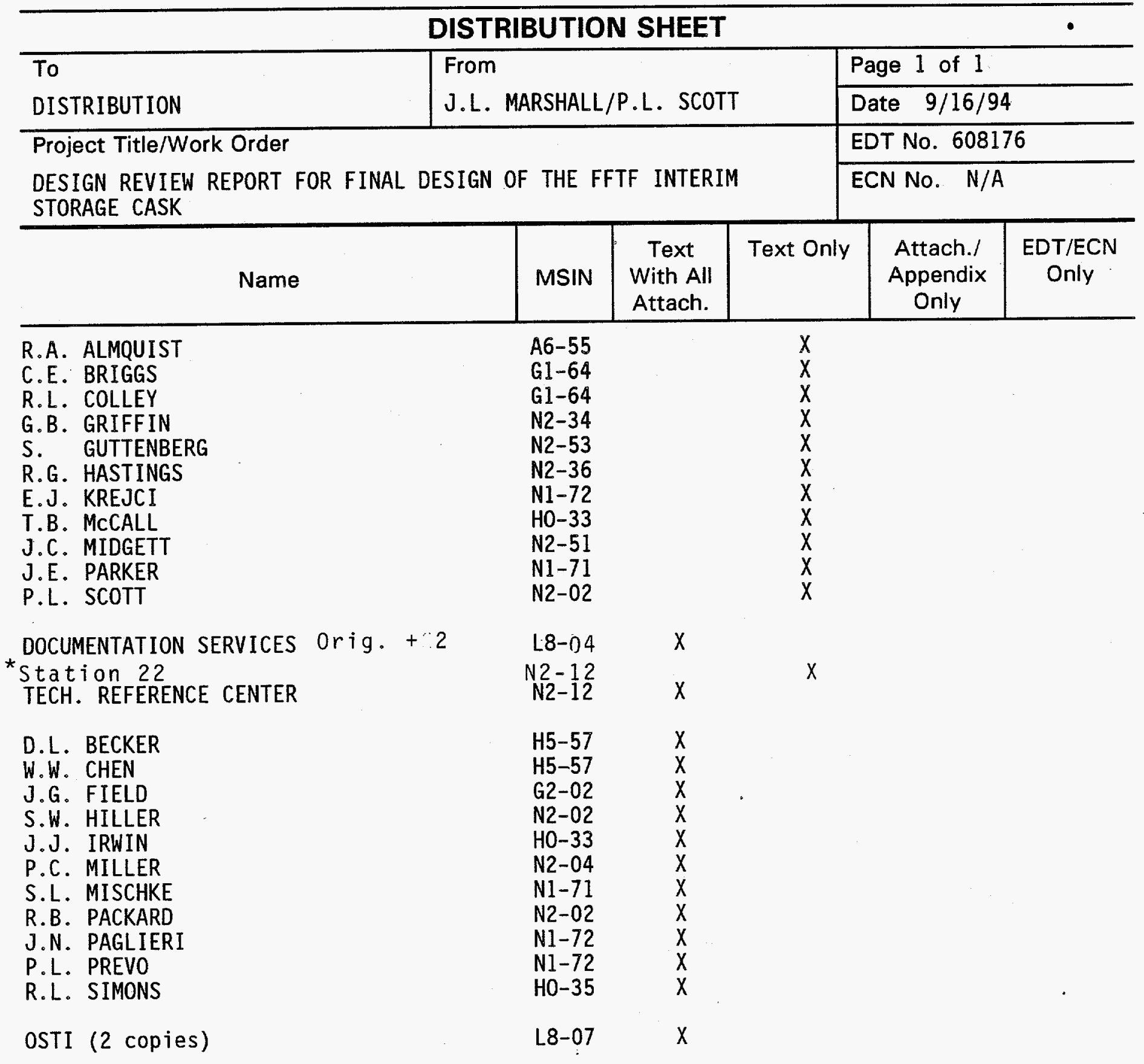

*Advanced Dist. Made 


\section{DISCLAIMER}

Portions of this document may be illegible in electronic image products. Images are produced from the best available original document. 


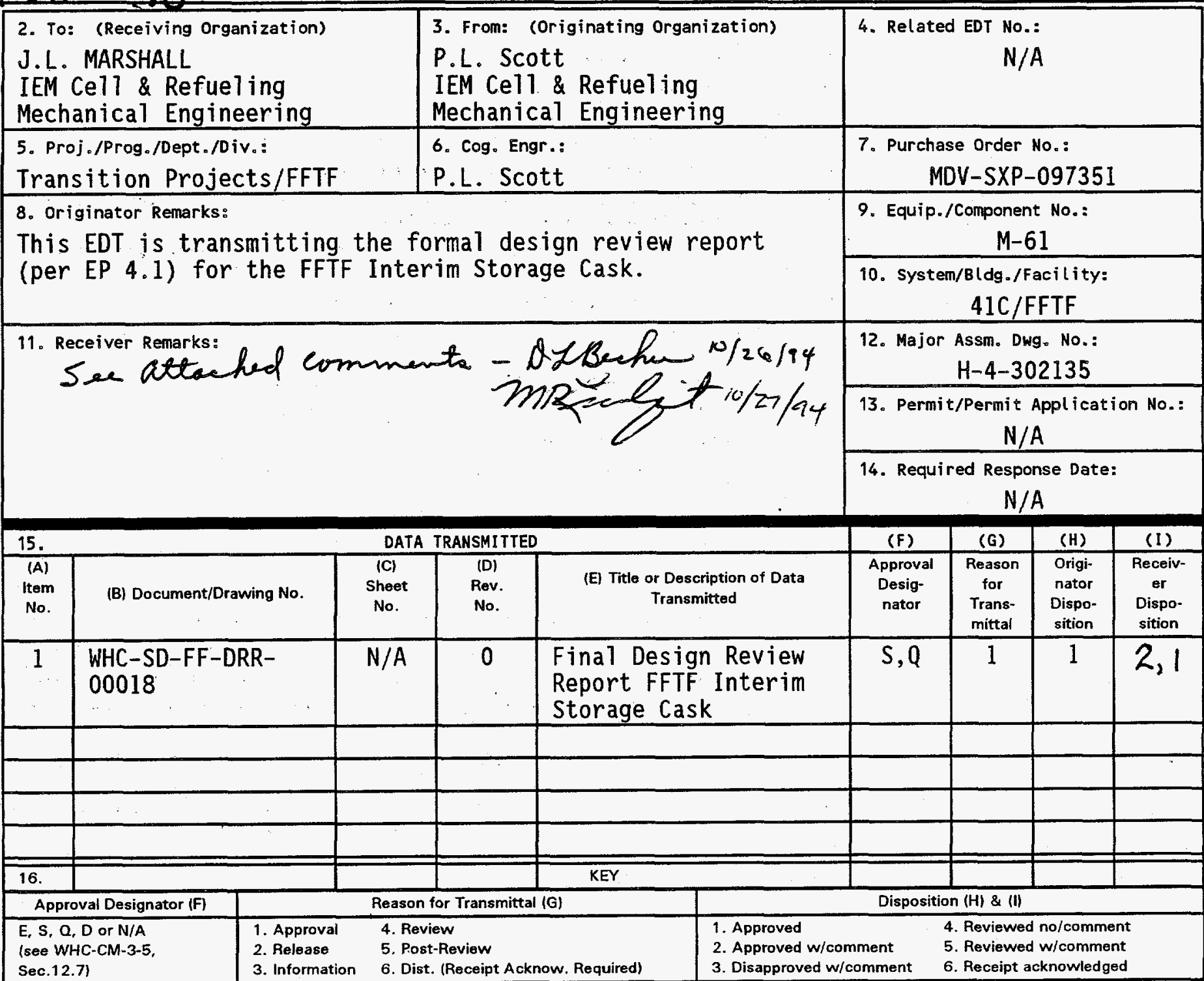

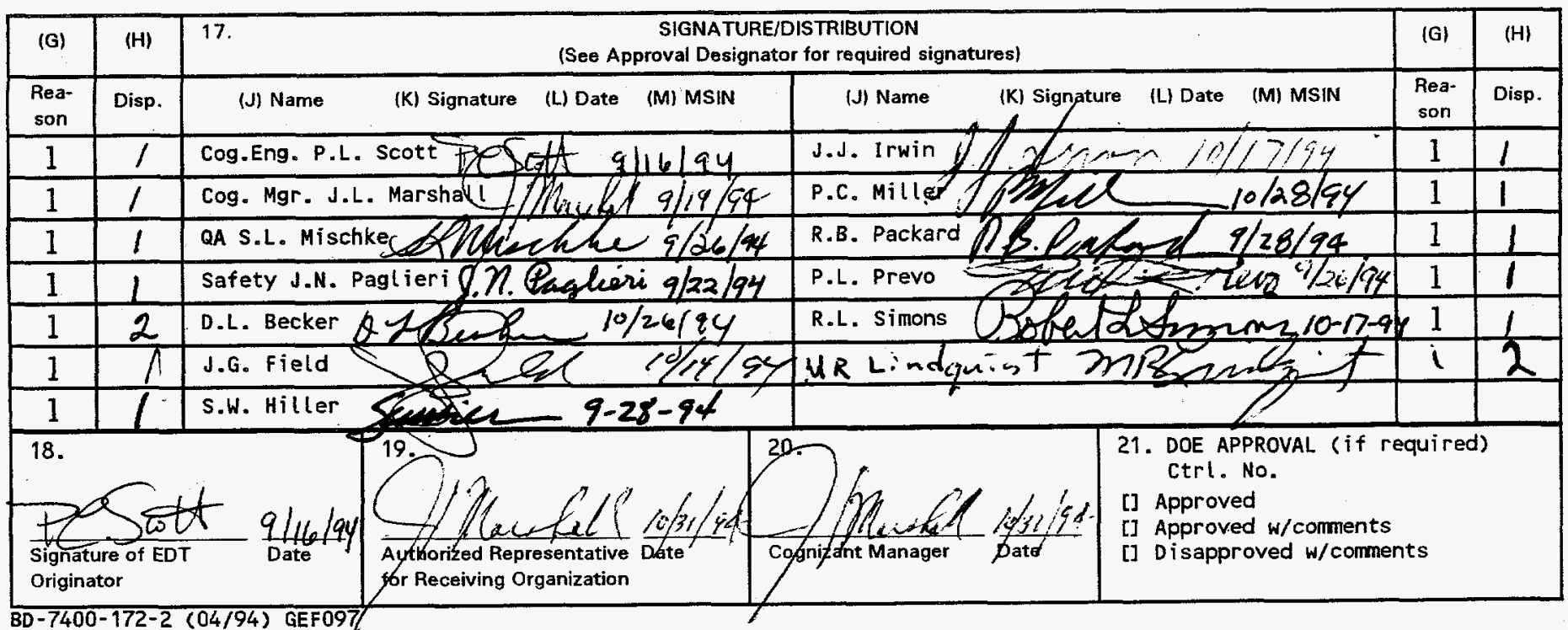




\section{EDT $60817 \%$ page 2 of 2}

\section{ATTACHMENT TO EDT 608176}

Approval of EDT 608176 is given with the following comments on WHC-SD-FF-DRR-00018, Design Review Report FFTF Interim Storage Cask.

Comment 1:

Subsequent to the above identified Design Review activity, General Atomics has requested a change in the materials designated for fabrication of the Interim Storage Cask (ISC) confinement boundary cylinder, flange and closure bottom plates. At the time of the subject design review. (August 25, 1994) the materials of construction for these components was designated to be A 203 and A 516. Subsequent to the design review, General Atomics has recommended that these materials be fabricated from $304 \mathrm{~L}$ stainless steel. Since the ISC design analysis and design review report do not reflect the effects of the recommended material substitutions, Facility Stress Analysis reserves.final concurrence of the ISC design until the impact of the recommended material changes have been assessed and reported on in the final design analysis report.

\section{Comment 2:}

Concerns expressed by Facility Stress Analysis regarding verification/ validation of the ILMOD computer code have not been fully or adequately addressed by General Atomics. The ILMOD Code is a proprietary code that General Atomics uses to calculate cask drop deformations. Facility Stress Analysis is conducting additional drop analyses of the ICS using alternative computer codes to assess the structural adequacy of the ISC design concept and for comparison to the ILMOD results. Facility Stress Analys is is not performing analyses to substantiate General Atomics' verification/validation of ILMOD. It is anticipated that concurrence by Facility Stress Analysis for adequacy of the ISC design to resist the affected drop conditions can be provided upon completion of these additional analyses. However, based on the analyses performed to date and engineering judgement, Facility Stress Analysis has given concurrence to proceed with purchase of sufficient material for fabrication of the first 10 ISC units.

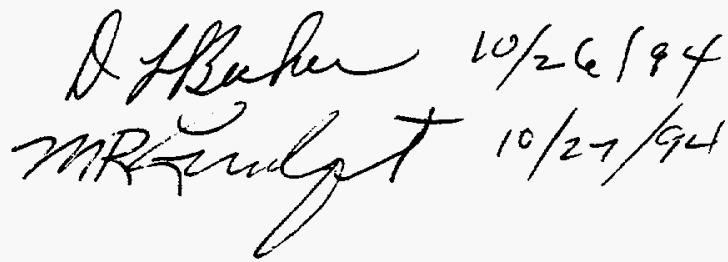




\section{RELEASE AUTHORIZATION}

Document Number: WHC-SD-FF-DDR-00018

Document Title: Design Review Report FFTF Interim Storage Cask

Release Date: $\quad$ December 6, 1994

This document was reviewed following the procedures described in WHC.CM-3-4 and is:

APPROVED FOR PUBLIC RELEASE

WHC Information Release Administration Specialist:

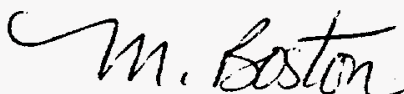

M.N. Boston

TRADEMARK DISCLAIMER. Reference herein to any specific commercial product, process, or service by trade name, trademerk, manufacturer, or otherwise, does not necessarily constitute or imply its endorsement, recommendation, or favoring by the United states Government or any agency thereof or its contractors or subcontractors.

This report has been reproduced from the best available copy. Available in paper copy and microfiche.

Printed in the United States of America. Available to the U.S. Department of Energy and its contractors from:

U.S. Department of Energy

office of Scientific and Technical Information (OSTI)

P.0. Box 62

Oak Ridge, TH 37831

Telephone: (615) 576-8401

Available to the public from:

U.S. Department of Commerce

National Technical Information Service (NTIS)

5285 Port Royal Road

Springfield, VA 22161

Telephone: (703) 487-4650 
2. Title

Design Review Report

FFTF Interim Storage Cask

5. Key Words

FFTF Interim Storage Cask ISC

3. Number

WHC-SD-FF-DRR-00018
4. Rev No.

0
6. Author

Name: P.L. Scott

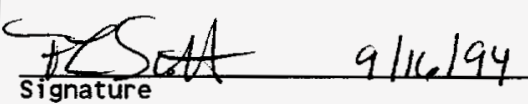

IEM Cell \& Refueling Mechanical

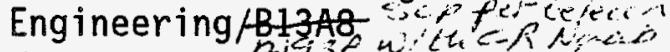
organization/Charge Códe $1 / 3 / 5$

\section{Abstract}

Final Design Review Report for the FFTF Interim Storage Cask. The Interim Storage Cask (ISC) will be used for long term above ground dry storage of FFTF irradiated fuel in Core Component Containers (CCC)s. The CCC has been designed and will house assemblies that have been sodium washed in the IEM Cell. The Solid Waste Cask (SWC) will transfer a full CCC from the IEM Cell to the RSB Cask Loading Station where the ISC will be located to receive it. Once the loaded ISC has been sealed at the RSB Cask Loading Station, it will be transferred by facility crane to the DSWC Transporter. After the ISC has been transferred to the Interim Storage Area (ISA), which is yet to be designed, a mobile crane will be used to place the ISC in its final storage location.

8. PURPOSE ANG USL OF DOCUMEAT within his dogament wats prepdred $f$ t use

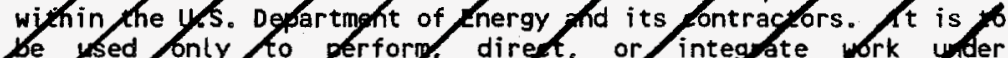

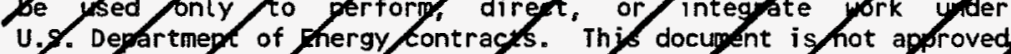
for pulic pelease unt iy/reviewed.

Eatent STATug - tors docynent coby, sirte it is transmitted in advance of pateny/clearapte, is prade aydilably in confidence soley fod use in performance of work unde contacts with the y.s. Dgpartmght of Entrgy. This dgeument/s not/o be pabl ishod nor its gontents otherfise digseminafed or pased for purpgses otper than spgtifier above before batent approvf for such rolease of use hat been setured, fon regaest, ffom the Pateny Counget. U.S Departyent of Energy $\mathrm{Fj}$ ld Offite, RjChland/WA.

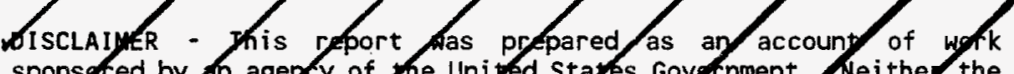
sponsfred by ah agepcy of the Unifed Stakes Govinment. Neithe the

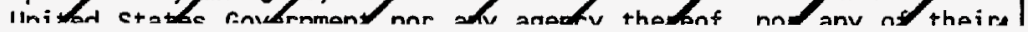

\section{DISCLAIMER}

10. RELEASE STAMP

OFEICIA! RELEASE By Aitis DATE DANO31395 stall

This report was prepared as an account of work sponsored by an agency of the United States Government. Neither the United States Government nor any agency thereof, nor any of their employees, makes any warranty, express or implied, or assumes any legal liability or responsibility for the accuracy, completeness, or usefulness of any information, apparatus, product, or process disclosed, or represents that its use would not infringe privately owned rights. Reference herein to any specific commercial product, process, or service by trade name, trademark, manufacturer, or otherwise does not necessarily constitute or imply its endorsement, recommendation, or favoring by the United States Government or any agency thereof. The views and opinions of authors expressed herein do not necessarily state or reflect those of the United States Government or any agency thereof.

\section{APPROVED FOR PUBLIC RELEASE \\ Information Release Authorization

$$
\begin{aligned}
& \text { bestar } \\
& 12 / 6194
\end{aligned}
$$


WHC-SD-FF-DRR-00018

Rev. 0

Page 1 of 9

\title{
FINAL DESIGN REVIEW REPORT
}

\author{
INTERIM STORAGE CASK
}

\section{DESIGN REVIEW OBJECTIVES AND FINDINGS}

A formal Design Review meeting was held with General Atomics (GA) on August 25, 1994 to review the final design for the Interim Storage Cask (ISC). The ISC will be used to provide secondary confinement for long-term, above ground, dry storage of Fast Flux Test Facility (FFTF) spent fuel. Primary confinement is provided by an unshielded Core Component Container (CCC) which will effectively "can" the fuel assemblies. The object of the meeting was to approve the Design Analysis Report and the detailed steel design of the ISC. The final design review was preceded by a preliminary design review which was held January 31, 1994.

The meeting notice and agenda for the design review are provided in Attachments 1 and 2. Attendees at the meeting, including the design review board members and their areas of responsibility, are identified in Attachment 3. A completed design review checklist, with appropriate actions, is provided as Attachment 4 . Copies of the Preliminary Design Review comments, and the dispositions of these comments, are provided as attachment 5. Copies of Review Comment Record (RCR) forms generated by the reviewers prior to the meeting, including the dispositions of each comment, are provided as Attachment 6. A copy of the Thermal Analysis evaluation and the verification analysis that was done is provided as Attachment 7. Additionally, General Atomic's responses to all the design review comments are provided as Attachment 8 since some of the comment dispositions refer to this document. Finally, any additional comments generated in discussion during the design review are presented below and the action required to resolve the issues are identified.

The meeting was conducted in accordance with EP-4.1 of WHC-CM-6-01, Design Verification Requirements, and per the attached agenda. It was the consensus of the review board that, with the exception of validation effort of the structural impact analysis which will proceed in parallel with the steel fabrication, that the design will be acceptable following incorporation or resolution of open items.

\section{COMMENTS/ACTIONS FROM DESIGN REVIEW DISCUSSION}

\subsection{Discussion: Scope of Project}

A brief history of the ISC project, the present status of the FFTF Shutdown, and the role the ISC plays in the overall plans were discussed. The meeting was then turned over to General Atomic's to present the ISC design.

Conclusion:

The ISC fabrication schedule is critical to the FFTF Spent Fuel offload schedule.

Action: None 
WHC-SD-FF-DRR-00018

Rev. 0

Page 2 of 9

\subsection{Discussion: Design Requirements}

The ISC is designed to the requirements of WHC-S-4110 Specification for FFTF Interim Storage Cask and 10CFR72 Licensing Requirements for the Independent Storage of Spent Nuclear Fuel and High-Level Radioactive Waste without licensing. The ISC provides secondary confinement and shielding for the Core Component Container (CCC). It is loaded in the Reactor Service Building Cask Loading Station (RSB-CLS) and is placed on the 400 Area storage site concrete pad which is designated as the Interim Storage Area (ISA). The ISC uses existing handling and transport equipment, and is designed for a 50 year life with minimal maintenance.

\section{Conclusion:}

The ISC was designed to the requirements.

\section{Action: None}

\subsection{Discussion: Design Description}

The ISC envelope meets WHC-S-4110 requirements. The envelope dimensions are as follows:

- $\phi 21.0 " X 146.5 "$ Long Cavity

- $\phi 84.64 " \times 180.41 "$ Long Cask

- $\quad$ 28.25" X 12.0" Thick Closure

- 114,190 1bs. Maximum Weight with 5,000 1b. CCC payload weight

The ISC Design is ventilated and is similar to Sierra Nuclear's NRC Ticensed VSC $^{\text {Tm }}$ Ventilated Storage Cask. The ISC is a steel vessel with integral concrete shielding. It has a top mounted closure with 16 bolts, redundant metal seals and a port for cask inerting and future cavity sampling, if required. The port has a quick-disconnect for sampling cask contents. The ISC closure design was modified from the proposal to provide redundant metallic seals. This meets 10CFR72 general licensing criteria and also facilitates leak testing of the closure both on initial assembly and while located on the storage pad. The ISC also has an internal impact limiter to limit the g level of the fuel should a CCC drop occur while loading at the RSB-CLS. Figure 1 shows the ISC design.

\section{Conclusion:}

The ISC was designed to meet the WHC requirements.

Action: None 
WHC-SD-FF-DRR-00018

\section{ISC DESIGN IS SIMILAR TO NRC LICENSED VSC}

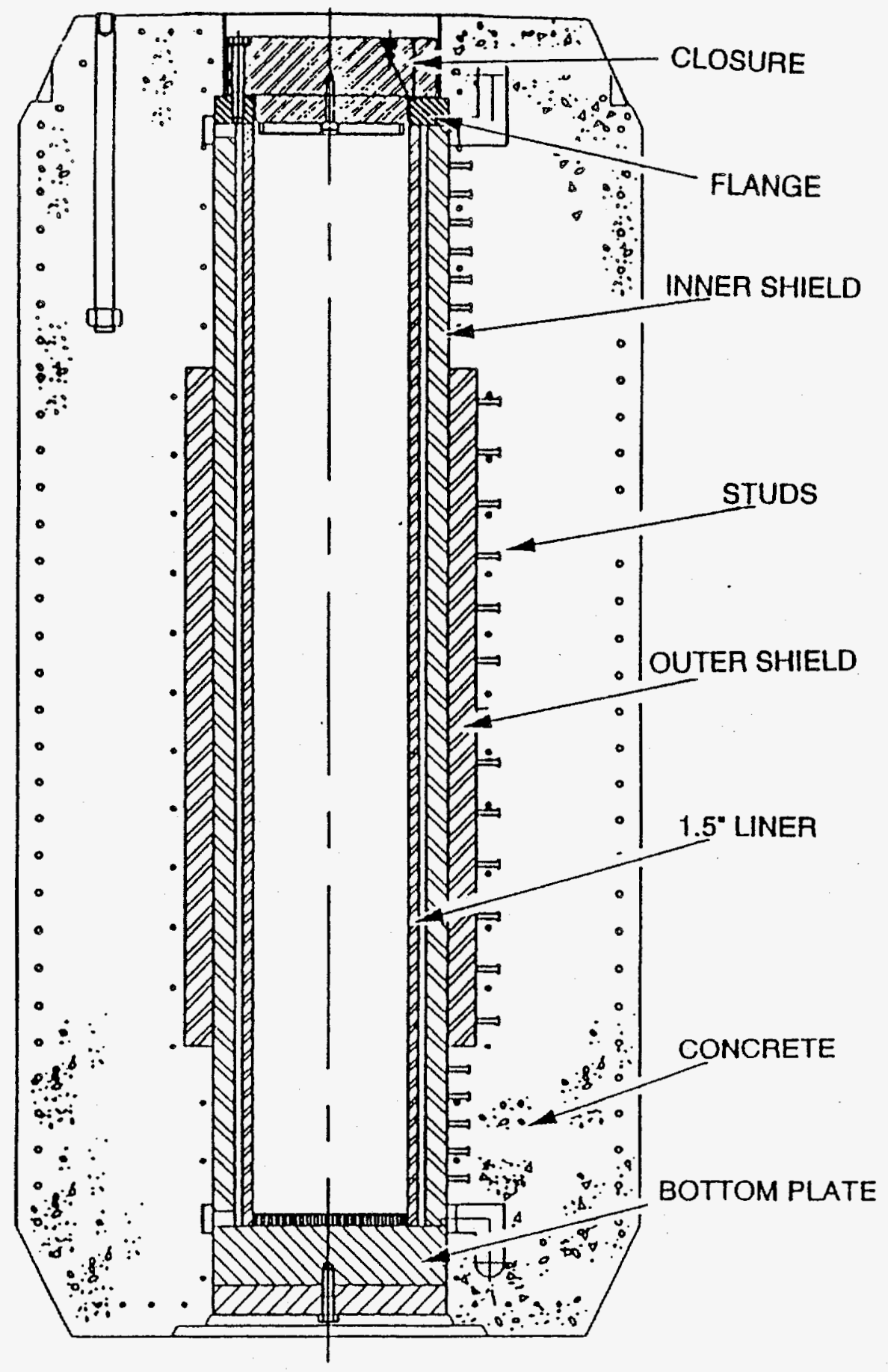

Figure 1: ISC Design 
WHC-SD-FF-DRR-00018

Rev. 0

Page 4 of 9

\section{Section 4.0 Discussion: Thermal Analysis}

The ISC thermal design requirements and evaluation results were presented by Rob Grenier of General Atomics. The following conditions were evaluated and their corresponding boundary conditions were discussed:

- Long-term Normal Hot

- Off-Normal Severe Hot

- Severe Cold

- Ash/Plugged Duct Accident

- Fire Accident per 10CFR71

The following conditions were used based on WHC input during the Preliminary Design Review:

- Added the Off-normal Severe condition

- No wind (Natural Convection)

- Hourly Temperature Variation

- Time and directional variation of solar

- Non-uniform Heat Flux

- Considered no solar to maximize gradients

- Considered transient heat-up with ash/plugged ducts

- Refined CCC Thermal properties

- Considered radiative heat loss from cask to environment

The results were discussed and it was highlighted that the FFTF ISC temperatures are considerably lower than casks licensed for use by the commercial industry, and even the ISC accident condition temperatures are less than what is typically allowed for normal conditions.

The WHC comments and resolutions were then discussed. Greg Field indicated that the temperatures in the closure seal area were not addressed for the fire accident. Marlin Lindquist and Dave Becker commented that the volumes of concrete used to define a "localized" area were not identified on the isotherm plots in an easily readable form. A comment concerning the thermal response of the cask while being held at a vacuum was discussed and stated to have no effect on ISC temperatures. John Irwin, however, indicated that it will have an effect on CCC/fuel temperatures and the vacuum condition would need to be evaluated. John Massey stated that, after draining the water from the cask, the commercial industry typically holds a vacuum for 30 minutes for 2 cycles to dry the fuel and inert the cask with Helium. Another comment concerning the spacing requirements of the ISC on the storage pad and the thermal limitations was discussed. GA analyzed for the closest cask spacing arrangement that was determined by WHC Industrial Safety to be acceptable and reported an overall increase in temperatures of five to ten ${ }^{\circ} \mathrm{F}$. This information will be included 
WHC-SD-FF-DRR-00018

Rev. 0

Page 5 of 9

in the DAR to allow evaluation of closer ISC spacing if additional casks are required to be stored in the ISA, which is yet to be designed.

Conclusion: The thermal analys is is acceptable pending resolution of action items.

Action: 1) The ISC Thermal Analysis will be expanded to cover the temperature response of the seal area during the fire accident.

2) The Isotherm plots will identify the volume extent of "localized" areas of concrete above the $150^{\circ} \mathrm{F}$.

3) GA will add discussion regarding the thermal effects of cask spacing that is closer than 5.5 feet.

4) WHC will evaluate the effect of vacuum on the CCC/fuel temperatures.

\section{Section 5.0 Discussion: Shielding Analysis}

The shielding analysis section of the DAR was presented by Jack Boshoven of General Atomics. The ISC was designed to meet the following shielding requirements as defined in WHC-S-4110:

- Source defined as 150,000 MWd/MTIHM burnup at approximately 4 years decay time

- Normal Condition dose rate requirements

Design $<2.0 \mathrm{mRem} / \mathrm{hr}$ at cask surface

Maximum acceptable $<5.0 \mathrm{mRem} / \mathrm{hr}$ localized area

- Following a handling accident, the dose rate must be $<1000 \mathrm{mRem} / \mathrm{hr}$ at one meter from the ISC surface.

The specification provided radiation source information such as:

- Material densities, volumes, and volume fractions used for development of spacial model.

- Neutron and gamma source definition

1.21 Peaking factor taken into account

$(n, \gamma)$ and subcritical neutron multiplication accounted for in neutron calculation

- Axially varying Co-60 activation source model

The total dose rate includes all contributing components such as; primary neutron source, subcritical neutron multiplication source, primary gamma source, secondary gamma source from $(n, \gamma)$ reactions and the scattering source from air both through the annulus and air ducts.

The ISC Shielding design meets ALARA for the normal conditions as the total design dose rate is $<2 \mathrm{mRem} / \mathrm{hr}$. Jim Paglieri asked about the assumptions used in the accident dose rate calculation. Jack Boshoven indicated that the Hypothetical accident calculation assumed that oniy 2 inches of concrete was left remaining on 
WHC-SD-FF-DRR-00018

Rev. 0

Page 6 of 9

the cask and the dose rate for this condition is a factor of 2 less than allowable per the specification after an accident. The 2 inches of concrete is extremely conservative since the structural analysis predicted 10 inches of concrete thickness would remain on the cask after a local penetration and 21 inches of concrete would be left after the free drop accident. These were the worst case accident conditions. Jack also indicated that even if all the concrete fell off the cask that the dose would be comparable to the accident dose rate allowable of 1000 $\mathrm{mRem} / \mathrm{hr}$ at a distance of one meter.

The specification requires that each ISC will be gamma scanned to verify there are no voids in the concrete shielding. The steel in the bottom and top closure of the ISC will have UT performed to verify no flaws in the shielding. This is more stringent than what is typically done in the commercial industry. GA indicated that this method does not verify shielding design for the vents and stated that the only meaningful verification for the vents would be to actually load fuel into the ISC. Therefore, final acceptance of the ISC shielding will be contingent on the Hot ATP results. GA questioned WHC's ability to define the source as this has been a problem with the older LWR fuel because impurities were not well controlled in the early steel specifications. Bob Simons responded that WHC has a high level of confidence in the DFA source due to very tight steel specification $(<0.05 \% \mathrm{Co})$ and also stated that the source had al so been measured. John Massey and Jack Boshoven stated that they had a high level of confidence in the vent calculations and indicated that for the VSC testing at the Idaho TAN facility that all doses at the vents were less than allowable.

Next the use of the PATH correction factor was discussed. GA stated that since the commercial fuel spectrum was very similar to FFTF fuel that this was justified.

Dave Becker indicated concern about preventing honeycombing of concrete during fabrication. GA stated that an experienced pre-cast fabricator is being utilized and tests and procedures were being developed to minimize this possibility. GA also stated that, if honeycombing was observable, the cask would be repaired. If honeycombing was not observable then the gamma scan would verify that there were no voids. John Massey indicated that the gamma scanning is not typically done on commercial casks and al so stated that the ACI-349 design methods account for the limitations in controlling concrete properties during the fabrication process.

Conclusion: The shielding design is acceptable pending resolution of open items.

Action: 1) WHC will include the vent dose rate verification in the Hot ATP.

2) WHC will review the concrete fabrication procedures with consideration for minimizing honeycombing.

3) GA will add $\mathrm{Pu}$ and $\mathrm{O}_{2}$ to shielding table for FFTF fuel description.

\section{Section 6.0 Discussion: Structural Analysis}

The Structural Analysis section of the DAR was presented by Maria Koploy of General Atomics. The ISC was evaluated for all required loads per the specification as follows: 
WHC-SD-FF-DRR-00018

Rev. 0

Page 7 of 9

Normal loads - Dead Load, Thermal, 1-ft free drop, lifting and tie-down, and vibration

Accident loads - 20-ft CCC drop, 4-ft free drop in RSB, 8-ft free drop on ISA pad, 40-in puncture, 20-ft RSB-CLS drop, and slapdown

Environmental conditions - Earthquake $0.12 \mathrm{~g}$, Wind $80 \mathrm{mph}$

The structural criteria was that the containment boundary allowables must conform to ASME Section III, subsection NC-3200. Guidance for the containment liner design analysis was taken from Reg. Guide 7.6 Design Criteria for the Structural Analysis of Shipping Cask Containment Vessels. The concrete design conforms to ACI-349 Code Requirements for Nuclear Safety Related Concrete Structures.

Standard concrete design methods are used consisting of; beam analysis, column analysis, shear-friction theory used for anchor stud shear load transfer between shields and concrete, lifting anchor design methods of ACI-349, and differential thermal expansion included.

The 1-ft and 4-ft drop analyses are the controlling conditions.

These analyses follow ACI-349 and NUREG/CR-3966 and show the ISC can withstand the following drops:

- 1-FT, 4-FT, and Slapdown drop onto unyielding surface Worst 1-ft drop stresses in end drop (160g) Worst 4-ft drop stresses in side drop (112.3g) All stresses below allowables

- 8-FT drop onto 1-FT thick concrete slab Used EPRI-NP-4830 Methodology

Pad and soil absorb energy

All stresses below allowables

Marl in Lindquist commented that concrete stresses were not well below allowables for an end drop and that the dynamic factor usage was not understandable for impact analysis. GA stated that the analys is is consistent with what is normally done in cask analysis and is conservative. GA also stated that the NAC cask was approved by the NRC without the use of any dynamic load factors in the analysis and this was based on cask tests. Marlin asked what the consequences would be if the damping was not considered in the analysis. GA stated that the concrete would be overstressed on an end drop but this would not be a safety concern as the design has plenty of margin on shielding and the containment boundary. Marlin stated that this argument should be made in the report. Dave Becker also commented that there was no explanation in the report of why there is no cask bounce during the drops and stated that justification for choosing the values used for dynamic strength increase factors also needed to be clarified. Overall, WHC still was unclear on the justifications of using earthquake motion damping to decrease the dynamic effects of impact loading. In addition, ILMOD results were not verified to actual concrete cask drops. WHC agreed to provide the SARP on Shippingport Reactors for further discussion on development of a bench-mark case to verify conservative ILMOD results. Resolution of this issue was deferred.

Greg Field made the comment that the analysis needed to be expanded in regard to seal area response during drop accidents and requested that data be provided on what decompression the metal seal could take and still maintain a seal or provide a discussion on the time response of the seal area. 
WHC-SD-FF-DRR-00018

Rev. 0

Page 8 of 9

Conclusion: There are open issues in the structural analysis. Specifically, GA has not provided the data that would demonstrate that the analysis method conservatively predicts the cask repose during impact loading. Subsequent to the Final Design meeting, WHC developed the project position that fabrication of the steel 1 iner and shielding can proceed in parallel with WHC development of a benchmark case to substantiate $\mathrm{GA}^{\prime} \mathrm{s}$ Structural analysis. Therefore, it is the conclusion that the ISC design will be considered acceptable and ready to proceed pending resolution of the items listed below and completion of the validation effort.

Action: 1) GA will expand the analysis of the closure area to show the leaktight requirement has been met.

2) GA will provide the NRC records that address the acceptability of not using dynamic load factors for cask analysis.

3) GA will add an explanation to the DAR on why there is no cask bounce after a drop.

4) GA will clarify the use of dynamic strength increase factors.

5) GA will address the thermal response of the closure seal area for the fire condition.

6) WHC will validate the results against actual concrete test data.

\section{Section 7.0 Discussion: Operations and Interface}

The ISC interfaces with the RSB-CLS, DSWC Transporter and DSWC Plug Handling fixture were presented by John Kissinger of General Atomics. The sequences required to load the cask, install the closure, and sample the cavity were also discussed. For the remote installation of the closure, WHC stated concern with possible binding of the closure alignment pins. WHC also stated concern about the cask concentricity required to support remote loading of the CCC. GA stated the method of tolerance achievement was still under development but the inner bore diameter to the outer cask diameter would be held to the true position indicated on the assembly drawings. The cask alignment feature to allow positioning of the ISC in the RSB-CLS was then described. This feature will consist of a 6 inch pipe centered in the lower shield plate of the cask. This pipe inner diameter will be held within 0.18 inches of the inner bore of the cask. This RSB-CLS will then be provided with a centering post that interfaces with the added cask feature. The bottom of the cask will have a higher dose rate due to the hole in the plate that allows the installation of the centering feature. This dose rate will be less than $200 \mathrm{mRem} / \mathrm{hour}$ and this is acceptable since it will be in an unaccessible area. Also discussed were the flatness requirements of the upper seal plate that interfaces with the RSB-CLS seal surfaces. Dick Packard stated that a $5 \mathrm{mil}$ flatness is required for this interface.

The closure seal design was discussed next. WHC indicated a high level of concern with a design that locates the seals in the cask. This is a concern because if final leaktight seal certification can not be achieved, then the fuel would have to be unloaded from the cask to replace the seals. In contrast, if the seals were in the closure, seal change-out and retest could be accomplished with minimal impact to worker ALARA and the fuel offload schedule. 
WHC-SD-FF-DRR-00018

Rev. 0

Page 9 of 9

The ISC Tiedown system was presented by Jim Baskin of Sierra Nuclear. The design wiTl use the existing DSWC trailer, struts, and ratchet binders. WHC commented on the positioning required of the ISC on the transporter to avoid interference of the tie-down equipment with the ventilation ducts and requested that match-marks be provided on the bottom of the cask to the transporter. WHC also requested that the dimension of the length of the tie-down equipment when lifted by slings be provided so that WHC could determine sling requirement. WHC also commented that a mag. particles inspection on the welds for the tie-down equipment would be preferable. The structural analysis was not determined to be in final form and WHC requested: that results tables be provided. WHC has an open item to evaluate how the tie-down equipment will measure up against new FHA requirements and if a specification change will be required at this time.

Conclusion: The ISC will be acceptable once the design is modified to reposition the seals to the closure versus the cask, provide an alignment feature, and provide a seal plate flatness of 5 mil to interface with the RSB-CLS.

Action: 1) Modify ISC design to move seals to closure.

2) Modify ISC design to provide an alignment feature for the bottom of the cask in the RSB-CLS. WHC will modify the specification to allow an exception to the $2 \mathrm{mRem} /$ hour dose rate in only this unaccessible area, specifically the bottom of the ISC.

3) Modify design to provide an upper seal plate flatness of 5 mils.

4) SNC will finalize Tie-down Analysis

5) Change Tie-down equipment weld inspection to Mag. Particle.

6) SNC will provide ISC to DSWC Transporter match mark.

7) WHC will evaluate tie-down equipment to new FHA requirements. 
From: IEM Ce11 \& Refueling Mechanical Engineering

Phone: $\quad 6-4128$ N2-02

Date: $\quad$ August 17, 1994

Subject: Formal Design Review for the FFTF Interim Storage Cask

\begin{tabular}{|c|c|c|c|c|}
\hline To: & $\begin{array}{l}\text { D. L. Becker } \\
\text { W. W. Chen } \\
\text { J. G. Field } \\
\text { S. W. Hiller } \\
\text { J. J. Irwin } \\
\text { P. C. Miller }\end{array}$ & $\begin{array}{l}H 5-57 \\
H 5-57 \\
G 2-02 \\
N 2-02 \\
H 0-33 \\
N 2-04\end{array}$ & $\begin{array}{l}\text { S. L. Mischke* } \\
\text { R. B. Packard } \\
\text { J. N. Paglieri } \\
\text { P. L. Prevo } \\
\text { P. L. Scott } \\
\text { R. L. Simons }\end{array}$ & $\begin{array}{l}\mathrm{N} 1-71 \\
\mathrm{~N} 2-02 \\
\mathrm{~N} 1-72 \\
\mathrm{~N} 1-72 \\
\mathrm{~N} 2-02 \\
\mathrm{H} 0-35\end{array}$ \\
\hline & $\begin{array}{l}\text { Cc: R. A. Almquist } \\
\text { C. E. Briggs } \\
\text { R. L. Colley } \\
\text { J. O. Greenborg } \\
\text { G. B. Griffin } \\
\text { S.. Guttenberg } \\
\text { E. J. Krejci }\end{array}$ & $\begin{array}{l}N 1-39 \\
G 1-64 \\
G 1-64 \\
H 0-35 \\
N 2-34 \\
N 2-53 \\
N 1-72\end{array}$ & $\begin{array}{l}\text { M. R. Lindquist } \\
\text { J. L. Marshall } \\
\text { T. B. McCall } \\
\text { J. C. Midgett } \\
\text { J. E. Parker } \\
\text { J. B. Waldo } \\
\text { JLM/FILE/LB }\end{array}$ & $\begin{array}{l}\mathrm{H} 5-57 \\
\mathrm{~N} 2-02 \\
\mathrm{H} 0-33 \\
\mathrm{~N} 2-51 \\
\mathrm{~N} 1-71 \\
\mathrm{~N} 2-57\end{array}$ \\
\hline
\end{tabular}

NOTE: Review Board Members are identified by asterisk $(*)$.

The Formal Design Review of the Interim Storage Cask (ISC) start time has been changed and will be held Thursday, August 25, 1994, 8:30 am $-3: 00 \mathrm{pm}, 1163$ (Procurement) Building, Room 272.

To assist in your preparation for the Formal Design Review Meeting there are small size prints of the ISC and a complete package of General Atomics's (GA) responses to the Final Design Review comments that were generated by WHC.

Please review GA's responses to your individual comments for close out. Also, please bring this package to the Design Review Meeting to facilitate discussions after each section presentation by GA and during the open items identification required at the completion of the Design Review Meeting.

Again, designated board members who are unable to attend the Design Review Meeting are requested to send a representative from within their organization.

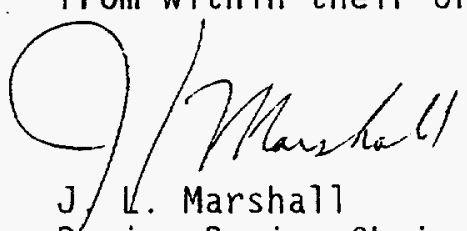

Design Review Chairman

pls

Attachments (2) 
INTRODUCTION

DESIGN REVIEW AGENDA

INTERIM STORAGE CASK

AUGUST 25

8:00 AM - 3:00 PM

1163 (PROCUREMENT) BUILDING, ROOM 272

SCOPE OF PROJECT

DESIGN REQUIREMENTS

DESIGN DESCRIPTION

DESIGN ANALYSIS REPORT

THERMAL ANALYSIS

SHIELDING ANALYSIS

STRUCTURAL ANALYSIS

OPERATIONS AND INTERFACE

CLOSURE INSTALLATION AND LEAK TESTING

CAVITY SAMPLING

CASK HANDLING

GENERAL DISCUSSION

DESIGN REVIEW DOCUMENTATION

OPEN ITEMS

CHECKLIST

ADJOURN 


\begin{tabular}{|c|c|}
\hline \multicolumn{2}{|c|}{ ISC FINAL DESIGN REVIEW ATTENDEES } \\
\hline NAME & REVIEW AREA \\
\hline \multicolumn{2}{|l|}{ GENERAL ATOMICS } \\
\hline Jack Boshoven & Shielding \\
\hline Maria Koploy & Structural/Project Engineer \\
\hline John Kissinger & Design Engineer \\
\hline Rob Grenier & Thermal/Project Manager \\
\hline Larry Boysen & Contracts \\
\hline \multicolumn{2}{|c|}{ SIERRA NUCLEAR CORPORATION } \\
\hline John Massey & ISC Design Consultant \\
\hline Jim Baskin & Tie-down Equipment Analyst \\
\hline \multicolumn{2}{|c|}{ WESTINGHOUSE HANFORD COMPANY } \\
\hline${ }^{*} J$. G. Field & Transportation and Packaging \\
\hline *J. N. Paglieri & Nuclear Safety \\
\hline *S. W. Hiller & $\begin{array}{l}\text { IEM Ce } 11 \text { \& Refueling Mechanical } \\
\text { Engineering }\end{array}$ \\
\hline "R. B. Packard & $\begin{array}{l}\text { IEM Cell \& Refueling Mechanical } \\
\text { Engineering }\end{array}$ \\
\hline${ }^{*}$ P. L. $S \operatorname{cott}(2)$ & ISC Project Engineer \\
\hline${ }^{*}$ P. R. Prevo & Radiological Safety \\
\hline j. L. Marshall (1) & Design Review Chairman \\
\hline *John J. Irwin & Thermal Analysis \\
\hline${ }^{*} \mathrm{Phil}$ Miller & Operations \\
\hline *Jim Duda & Quality Assurance \\
\hline *Robert Simons & Shielding Analysis \\
\hline M. R. Lindquist & Structural Analysis \\
\hline${ }^{*} \mathrm{D}$. L. Becker & Structural Analysis \\
\hline \multicolumn{2}{|l|}{ DOE-RL } \\
\hline R. G. Hastings & Oversight \\
\hline
\end{tabular}

* Design Review Committee Member

(1) Design Review Chairman

(2) Design Review Secretary 


\section{DESIGN REVIEW CHECKLIST}

ISC Final Design Review for General Atomic's Contract MDV-SXP-097351

\section{Submittals:}

ISC Design Analysis Report (GA \# 910683/0)

$\mathrm{H}-4-302134$ ISC Outline/Interface

$\mathrm{H}-4-302135$ ISC Assembly Drawing

H-4-302136 ISC Tiedown System

\begin{tabular}{|c|c|c|c|c|c|}
\hline \multicolumn{2}{|r|}{$\begin{array}{c}\text { System/Component } \\
\text { Interim Storage Cask }\end{array}$} & \multicolumn{3}{|c|}{$\begin{array}{c}\text { Design Phase } \\
\text { Final }\end{array}$} & $\begin{array}{c}\text { General Atomics } \\
\text { Contract MDV-SXP-097351 }\end{array}$ \\
\hline Item & Review Consideration & Yes & No & NA & Remarks \\
\hline 1 & $\begin{array}{l}\text { Have assumptions necessary to } \\
\text { perform the design task been } \\
\text { identified and adequately } \\
\text { described and are they } \\
\text { reasonable? }\end{array}$ & 8 & & & \\
\hline 2 & $\begin{array}{l}\text { Does the design meet the } \\
\text { established requirements or } \\
\text { design criteria? }\end{array}$ & $\checkmark$ & & & $\begin{array}{l}\text { Except as noted in open } \\
\text { items }\end{array}$ \\
\hline 3 & $\begin{array}{l}\text { Does the design meet the } \\
\text { functional limits? } \\
\text { a. Stresses are within } \\
\text { design limits? } \\
\text { b. Steady-state and } \\
\text { transient conditions? } \\
\text { c. Accident conditions? }\end{array}$ & $\begin{array}{c}d \\
d \\
d\end{array}$ & & & $\begin{array}{l}\text { Except as noted in open } \\
\text { items: } \\
\text { Final Tie-down Stress } \\
\text { report corrections. } \\
\text { ILMOD modeling } \\
\text { acceptance. }\end{array}$ \\
\hline 4 & $\begin{array}{l}\text { Will the design meet the } \\
\text { following environmental } \\
\text { conditions? } \\
\text { a. Temperature (steady- } \\
\text { state and transient) } \\
\text { b. } \quad \begin{array}{l}\text { Pressure (steady-state } \\
\text { and transient) }\end{array} \\
\text { c. Seismic/natural } \\
\text { phenomena } \\
\text { d. Nuclear radiation }\end{array}$ & $\begin{array}{l}\checkmark \\
\checkmark \\
\checkmark\end{array}$ & & & $\cdot$ \\
\hline 5 & $\begin{array}{l}\text { Does the design meet all } \\
\text { established safety } \\
\text { requirements? }\end{array}$ & $\checkmark$ & & & \\
\hline
\end{tabular}


$W H C-S D-F F-D R R-00018$

Rev。 0

\begin{tabular}{|c|c|c|c|c|c|}
\hline \multicolumn{2}{|r|}{$\begin{array}{l}\text { System/Component } \\
\text { Interim Storage Cask }\end{array}$} & \multicolumn{3}{|c|}{$\begin{array}{l}\text { Design Phase } \\
\text { Final }\end{array}$} & \multirow{2}{*}{$\begin{array}{c}\begin{array}{c}\text { General Atomics } \\
\text { Contract MDV-SXP-097351 }\end{array} \\
\text { Remarks }\end{array}$} \\
\hline Item & Review Consideration & Yes & No & NA & \\
\hline 6 & $\begin{array}{l}\text { Have the appropriate Quality } \\
\text { Assurance requirements been } \\
\text { specified? }\end{array}$ & $\checkmark$ & & & \\
\hline 7 & $\begin{array}{l}\text { Have all credible non-standard } \\
\text { conditions been properly } \\
\text { considered? }\end{array}$ & 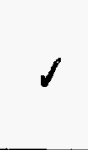 & & & \\
\hline 8 & $\begin{array}{l}\text { Is the design in compliance } \\
\text { with applicable regulatory } \\
\text { requirements? }\end{array}$ & 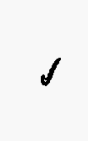 & & & \\
\hline 9 & $\begin{array}{l}\text { Are the applicable codes, } \\
\text { standards and requirements, } \\
\text { including revisions, properly } \\
\text { identified and are their design } \\
\text { requirements provided for? }\end{array}$ & $d$ & & & \\
\hline 10 & $\begin{array}{l}\text { Are there any interface } \\
\text { problems? }\end{array}$ & 8 & & & $\begin{array}{l}\text { Except as noted in open } \\
\text { items. }\end{array}$ \\
\hline 11 & $\begin{array}{l}\text { Are the specified material } \\
\text { compatible with each other and } \\
\text { the environmental conditions to } \\
\text { with the material will be } \\
\text { exposed? }\end{array}$ & $\checkmark$ & & & \\
\hline 12 & $\begin{array}{l}\text { Does the design avoid any } \\
\text { materials unproven for use in } \\
\text { the anticipated environments? }\end{array}$ & $\checkmark$ & & & \\
\hline 13 & $\begin{array}{l}\text { Have non-corrosive materials } \\
\text { been used where required? }\end{array}$ & $\checkmark$ & & & \\
\hline 14 & $\begin{array}{l}\text { Can the assembly be stored for } \\
\text { extended periods of time } \\
\text { without degrading effects? }\end{array}$ & $\sqrt{ }$ & & & \\
\hline 15 & $\begin{array}{l}\text { Are coatings compatible with } \\
\text { the expected environment? With } \\
\text { expected usage? }\end{array}$ & $\checkmark$ & & & \\
\hline 16 & $\begin{array}{l}\text { Do manufacturing, processing, } \\
\text { and fabrication procedures } \\
\text { minimize stress corrosion and } \\
\text { fatigue? }\end{array}$ & $\checkmark$ & & & \\
\hline
\end{tabular}


WHC-SD-FF-DRR-00018

Rev. 0

\begin{tabular}{|c|c|c|c|c|c|}
\hline \multicolumn{2}{|r|}{$\begin{array}{l}\text { System/Component } \\
\text { Interim Storage Cask }\end{array}$} & \multicolumn{3}{|c|}{$\begin{array}{l}\text { Design Phase } \\
\text { Final }\end{array}$} & \multirow{2}{*}{$\begin{array}{c}\text { General Atomics } \\
\text { Contract MDV-SXP-097351 } \\
\text { Remarks }\end{array}$} \\
\hline Item & Review Consideration & Yes & No & NA & \\
\hline 17 & $\begin{array}{l}\text { Have welding, bolting, joining } \\
\text { methods been adequately } \\
\text { specified? }\end{array}$ & $\checkmark$ & & & $\begin{array}{l}\text { Except for open item to } \\
\text { add mag. particle } \\
\text { inspections for tie- } \\
\text { down equipment. } \\
\text { Welding final approval } \\
\text { will be acceptance of } \\
\text { fabrication procedures. }\end{array}$ \\
\hline 18 & $\begin{array}{l}\text { Is the design producible by } \\
\text { conventional means? }\end{array}$ & $\checkmark$ & & & \\
\hline 19 & $\begin{array}{l}\text { Can the equipment be readily } \\
\text { assembled/disassembled as } \\
\text { designed? Using conventional } \\
\text { means? }\end{array}$ & $\checkmark$ & & & \\
\hline 20 & $\begin{array}{l}\text { Are assembly clearances } \\
\text { adequate? }\end{array}$ & $\sqrt{ }$ & & & \\
\hline 21 & $\begin{array}{l}\text { Has appropriate consideration } \\
\text { been given to uses of } \\
\text { standardized parts, materials, } \\
\text { and processes, and have } \\
\text { engineering standards and } \\
\text { criteria been specified } \\
\text { properly in the design? }\end{array}$ & $\checkmark$ & & & $\cdot$ \\
\hline 22 & $\begin{array}{l}\text { Are required tolerances, } \\
\text { fabrication techniques, } \\
\text { processes, etc., consistent } \\
\text { with standard practices? }\end{array}$ & $\checkmark$ & & & $\begin{array}{l}\text { Except for open item to } \\
\text { provide alignment } \\
\text { feature and } 5 \text { mil } \\
\text { flatness seal interface } \\
\text { plate }\end{array}$ \\
\hline 23 & $\begin{array}{l}\text { Can the design and its parts be } \\
\text { easily inspected for } \\
\text { conformance to engineering } \\
\text { specifications? }\end{array}$ & $\checkmark$ & & & \\
\hline 24 & $\begin{array}{l}\text { Has the design appropriately } \\
\text { considered maintenance, } \\
\text { reliability, including } \\
\text { maintenance procedures and } \\
\text { techniques, unique maintenance } \\
\text { requirements? }\end{array}$ & $d$ & & & \\
\hline 25 & $\begin{array}{l}\text { Is the equipment design } \\
\text { adequate to implement the } \\
\text { proposed maintenance } \\
\text { philosophy? }\end{array}$ & $\checkmark$ & & & \\
\hline
\end{tabular}


WHC-SD-FF-DRR-00018

Rev. 0

\begin{tabular}{|c|c|c|c|c|c|}
\hline \multicolumn{2}{|r|}{$\begin{array}{l}\text { System/Component } \\
\text { Interim Storage Cask }\end{array}$} & \multicolumn{3}{|c|}{$\begin{array}{l}\text { Design Phase } \\
\text { Final }\end{array}$} & \multirow{2}{*}{$\begin{array}{c}\begin{array}{c}\text { General Atomics } \\
\text { Contract MDV-SXP-097351 }\end{array} \\
\text { Remarks }\end{array}$} \\
\hline Item & Review Consideration & Yes & No & NA & \\
\hline 26 & $\begin{array}{l}\text { Has adequate accessibility been } \\
\text { provided for in-service } \\
\text { inspection? }\end{array}$ & $\checkmark$ & & & \\
\hline 27 & $\begin{array}{l}\text { Have adequate acceptance } \\
\text { criteria been specified and are } \\
\text { the verification methods stated } \\
\text { appropriately? }\end{array}$ & $d$ & & & \\
\hline 28 & $\begin{array}{l}\text { Have NDE methods been applied } \\
\text { correctly? }\end{array}$ & $\downarrow$ & & & $\begin{array}{l}\text { Except for open item to } \\
\text { add mag. particle } \\
\text { inspections for tie- } \\
\text { down equipment. } \\
\text { Welding final approval } \\
\text { will be acceptance of } \\
\text { fabrication procedures. }\end{array}$ \\
\hline 29 & $\begin{array}{l}\text { Have necessary features been } \\
\text { provided to maintain personnel } \\
\text { radiation exposure as low as } \\
\text { reasonably achievable (ALARA)? }\end{array}$ & $d$ & & & \\
\hline 30 & $\begin{array}{l}\text { Have allowable leakages been } \\
\text { specified? }\end{array}$ & $d$ & & & \\
\hline
\end{tabular}


WHC-SD-FF-DRR-00018

Rev。 0

ATTACHMENT 5

PRELIMINARY DESIGN REVIEW COMMENT RECORD 


\section{THERMAL}

1) The thermal analysis for normal storage conditions was based upon a two dimensional steady state analysis that assumed an average ambient temperature of $94^{\circ} \mathrm{F}$ and an averaged solar insolation for the peak summer month of JuTy (per the ISC specification). The averaged solar insolation was derived by summing the transient solar insolation for the side of the cask and dividing by 24 hours. A similar process was done for the top of the cask. also the average temperature is based upon averaging over a 24 hour period the transient temperatures from the ISC specification. While this will produce a nominal average temperature distribution through the cask, it does not provide a true peak temperature distribution. Note; the General Atomics thermal analysis methodology has not been acceptable in the past to the NRC (and DOE) for the licensing of shipping casks. A technique that has been acceptable to the NRC/DOE; is to average the solar insolation over a 12 hour period and then perform a 20 steady state analysis, ie., GA's thermal energy input from solar insolation is $1 / 2$ of what has been acceptable to the NRC.

2) To assess long term concrete, steel, and fuel assembly effects the peak temperatures, time averaged over 50 years, may be important. This would require a three dimensional transient analysis (10 to 15 day simulated transient). Also peak surface temperatures for personnel protection should be determined for peak solar and peak ambient conditions.

3) The thermal analysis appears to have been based upon constant thermal material properties. The thermal properties should be a function of temperature.

4) The thermal material properties for the aluminum honeycomb impact limiter and volcanic ash should be tabulated in the report.

5) The thermal material property for concrete was determined for a general concrete and not the specific reinforced concrete to be used in the cask. Data for the specific concrete shou?d be used, experimental data would be the best.

6) The fire analysis did not include the effect of paint combustion. See attachment 3 . 
7) The flow analysis for air flow through the ventilation ducts was in principal proper. The analysis could not be verified as definitive dimensions of the flow path were not presented in the analysis. Figures depicting the flow geometry should be presented. Also the convection correlation used for the annular region of the cask was based upon enclosed vertical plates. A correlation for cylindrical annular surfaces with open channel flow would provide a more realistic analysis. A proper correlation can be found in Guyer, E. C., 1989, Handbook of Applied Thermal Design, McGraw-Hi1l Book Co., New York, New York.

8) The effects of adjacent casks needs to be addressed in the final analysis. The siting array should be specified, from this, convection patterns, heat loss by thermal radiation and ground effects would be addressed.

9). The thermal and physical properties for the Core Component container with six DFAs should be determined by FFTF personnel (with input from the WHC Thermal Analysis support group) and supplied to GA. GA's report contains some of these calculations, they appear to be in error.

10) The thermal contact resistance between the ISC and the concrete pad it will rest upon is presented as $500 \mathrm{Btu} / \mathrm{hr}-\mathrm{sq}$. ft- ${ }^{\circ} \mathrm{F}$. This appears to be excessively high. GA should document how this number was determined, this value is usually based upon tabulated experimental data (from handbooks).

11) The thermal analysis report should contain figures that depict the cask thermal model. Figures depicting cask dimensions, materials and thermal boundary conditions would be helpful. A figure depicting the thermal model node network would also be helpful. Unnecessary computer printouts should be removed.

12) Some of the thermal equations listed in the report could not be found in the specified references, eg., those equations referenced from the Handbook of Heat Transfer. The author should verify this and provide a copy of the applicable pages from the referenced handbook.

13) The validation report for GA thermal analysis computer program should be supplied to WHC for review. 
14) Section 2.3, page 1, and Thermal Evaluation Section 4.0, page 4-6: the calculations are based on time-averaged temperature of the outside environment of $94 \mathrm{~F}$. The 10CFR72, subpart F, $72.122(i)$, requires that "Host severe of the natural phenomena reported for the site and the surrounding area" be considered. In this case, WHC-S-4110, page 21 , Table 1, gives most severe environment temperature of $115 \mathrm{~F}$.

15) All heat dissipation is based on Natural Convection and passive cooling. I cannot justify forced convection modelling with constant wall temperature as has been assumed on Page 4-6, of Thermal Evaluation section. It may also be pointed out that daily average wind of 8 mph, does not justify forced convection modelling either.

16) The adequacy of cooling and temperatures if the ISC is on its side should be discussed (e.g. ISC on its side due to a drop accident or transfer tip over).

17) Will ash prevent convective cooling?

18) State whether any spacing between cask for thermal or shielding consideration is needed. 


\section{SHIELDING COMMENTS}

1) The equation 7.10-8 in Schaeffer's text (reference 5.5) was developed for neutron scattering through a multi-legged duct. It also will probably work for gamma rays with appropriately chosen parameters; however, this should be demonstrated by comparing it to measured gamma ray data for multi-legged ducts. Schaeffer's text may have the necessary data for this comparison.

2) The geometry of the duct allows a direct streaming path to the duct exit as is shown in the attached figure 1 . Very 1 ittle concrete is available for shielding. If a driver fuel assembly is placed adjacent to the duct, rough calculations indicate a dose rate at the screen (part 24) location may be as high as $40 \mathrm{rem} / \mathrm{hr}$. The duct dimensions (diameter or length of legs) may be changed to reduce the dose rate. This comment is applicable to both the top and bottom ducts.

3) Each driver fuel assembly should be modeled individually to assure the dose rates at the side of the ISC is conservative.

4). Is there quality documentation for the verification and validation of the two radiation shielding codes TWODANT AND PATH?

5) The loss of water in the concrete over the 50-year storage period should be considered in the shielding analysis.

6) State what weight ISC was used for the shielding calculations. 


\section{STRUCTURAL}

1) Computer codes ILMOD, GACAP, and SAC: GA states that GACAP is verified against the DYNA3D and SCANS computer codes. SCANS is useful for circular steel containers with dumb-bell type impact limiters. Is the application of GACAP suited to concrete containers? Please provide the technical basis for the use of all computer codes and provide evidence that these codes have been verified and/or benchmarked by tests or analyses of evaluation of concrete containers. Are the codes that are being used to make design decisions recognized by industry and are they intended for use as design tools?

2) Drop Analysis: Paragraphs 3.2.2.8.2(3) and (4) of WHC-5-4110 require drops on a horizontal concrete surface. Please provide technical justification to show that the l-ft-thick concrete slab used in the design calculations provides sufficient rigidity and mass to meet the specifications intent. Also, the final design analysis should address the effects of variations in concrete properties on the dynamic response of the ISC and target.

3) Seismic Analysis: Per paragraph 3.2.2.8.4 of WHC-5-4110, an Importance Factor of 2.0 should be used in seismic analyses. The preliminary design does not account for the importance factor. Please address this issue.

4) Effects of Temperature On Concrete: Please provide a detailed discussion of the maximum thermal stresses and maximum and minimum temperatures of the various ISC structural components (steel and concrete) and the associated reduction in mechanical properties at the extreme temperature limits. This discussion should be concerned with showing conformance with the stipulated codes requirements and provisions. Also, since the ISC design will most likely be finalized before the concrete mix design is selected, please address how the variations in concrete properties will be accounted for and controlled in the design mix selection and verification process.

5) Freeze/Thaw cycles: Please address the concrete properties at cold temperatures and how these may affect long-term performance of the ISC? (See comment 5. above). Also, please discuss how the design can accommodate repeated cycles of freezing and thawing. 
WHC-SD-FF-DRR-00018

Rev. 0

6) Vents: Please identify what provisions have been made to prevent water, dirt, and debris from blocking the vents? What increase in temperature would result if blockage of the vents occurred? Please address the possibility and consequences of corrosion in the vented annulus region between the containment and shielding (particularly for low heat load conditions). What maintenance activities can be performed to cope with degradation of the paint on the annulus surfaces.

7) Welds: All structural fillet welds should be full penetration welds.

8) Load Paths: Please provide a discussion of the load paths for the various storage cask loading conditions. Explain the load path through the structural welds and shear studs, and address what load is distributed among these components. Also, please discuss the interface loads of the payload support structure with the ISC containment.

9) ASME Criteria: The ISC Design Specification stipulates that the containment vessel is to be designed in accordance with ASME Section III, Class 2 requirements. It appears that Class 1 ( $S_{m}$ values) are being used in the design analysis. Paragraph NCA-2134 (Optional Use of Code Classes) of the ASME Code does state that Class 2 items may be constructed as class 1 items. It is implied, however, that one must accept all of the requirements of Class 1 (e.g. material pedigree, design equations, quality assurance, inspection, fabrication procedures) if the item is analyzed as a class 1 item. Therefore, please provide further justification for the use of class 1 material allowables ( $S_{\text {in }}$ values) rather than Class 2 allowables (s values).

10) Section 2.7, Structural Design, is based on Non-reactor Safety Class 2, design criteria. It uses ASME B \& $P V$ code Section III, Subsection NC. However, in Tables 3.4-2 and 3.4-5, the document makes reference to subsection NB. I think this is conservative detailed calculation methodology adopted in this document, because $N B$ is more severe and stringent than Subsection NC. Please clarify if different.

11) Pages 12 and 19, somewhere in the middle of the page, refer to UCRLij910 Table 4-4 "Recommended Damping Values". The Table 4-4, should be Table 4-6. Please check. 
12) The Weight of the Cask has been used 112,000 1b, 120,000 1b, and 118,000 1b. Fortunately it has been used conservatively in the calculations.

13) Material Properties, Section 3.3.1, does not present the material properties of ASTM A $325, A-82$ or A-185, A-615 which have been used in the structure of Cask.

14) An accidental drop of the portable crane boom at the ISA onto the ISC should be analyzed. (WHC can supply data)

15) Were circumfrential deformations and stresses that result from differential thermal expansion considered?

16) The analysis should consider whether repeated cycles of thermal loadings, together with other loadings, will cause fatigue failure or extensive accumulations of deformation.

17) Should the stresses that occur during the fire be evaluated to show that the cask maintains its integrity?

18) Add a caution statement that accidental drop of the CCC into the ISC assumes a fully loaded $C C C$. The number of $\mathrm{g}^{\prime} \mathrm{s}$ that is experienced by the fuel would be greater for a partially loaded CCC.

19) Explicitly state whether there is an impact limiter for the ISC.

20) Stress Analyses: Please provide a discussion of the stresses resulting from the various loading conditions, particularly the stresses

(longitudinal and circumferential) in the steel and concrete resulting from thermal expansion and temperature gradients. 
21) Analyses Data: The final stress analysis documentation package should contain hard copies of all input data, post processing commands, and any data extracted from the computer output that is used in the analys is (e.g, tables, graphs, plots, etc.)

22) Bolting Allowables: Please provide justification for the use of $2 \mathrm{~S}_{\mathrm{m}}$ and $3 S_{m}$ as the allowable stresses for bolts.

23) Design Bases: During the preliminary design review meeting of January 31, 1994, the General Atomics representatives frequently made reference to a previous cask design as the bases and/or justification for the ISC design. It should be emphasized that where a previous design is referenced as a basis for the ISC design, then the final design report should include all necessary information to correlate the previous design to the ISC design and to substantiate that the previous design constitutes a valid design basis. 
1) The ability/method to be used to leak check and monitor the ISC cover seal using the single metallic o-ring is unclear. A review of the design of bolted closures on other NRC licensed storage casks indicates that double seals are always used and in some cases two and even three sets of double o-rings are required. The design of the ISC closure does not appear to be consistent with other NRC Ticensed designs.

2) Leak Testing, Section 1.2.3, page 4. The Cask is known to have or develop an internal pressure of 50 psig. The document indicates that the integrity of the seals and the cask is to be tested only to 5 psig. I cannot find explanation anywhere why? please clarify.

2) There is not enough information on containment criteria and leakage rate testing to completely evaluate these features.

3) A temporary seal or method to torque the plug bolts to maintain a seal and contain the cask inert prior to breaking the boundary is required. The method to do this is unclear on the proposed design. e.g, the plug must be sealed prior to removing the DSWC FV.

4). The 15" chamfer on the upper end of the cask is not compatible with the MASF CLS upper restraints as shown on drawing H-4-66809.

NOTES: 1) The chamfer on the proposal was $5.1 / 2$ " which was compatible.

2) The adapter for the bottom of the cask in the RSB CLS is presently in the design phase therefore the $15^{\prime \prime}$ chamfer on the bottom of the cask can be accommodated.

3) The dimensions on these interfacing chamfers must be controlled in the manufacturing process.

5) An alignment feature for plug insertion must be provided to assure the. bolts align with the mating holes in the cask body.

6) We assume the cask lift lugs are removable as this is required at the RSB CLS for installation of the CLS cover/seal plate. 
7) Is the inner diameter of the cask sufficient to allow retrieval of the CCC after the specified 50 year storage period? The specification requires the seller to use good engineering judgement in providing this dimension. Note that due to the tight dimensions of the sealing surface the lower dimension of the CCC was reduced to avoid damage to the sealing surface during cask loading. Does the reduction of the diameter of the CCC base plate affect the interface with the cask impact limiter?

8) The cask drawing shows the upper seal plate to be 1/4" thick. Is this sufficient to allow for machining to provide the required $0-r i n g$ surface finish and structural rigidity?

9) Interface drawings need to identify controlled dimensions. Affirm date that dimensions will be considered controlled.

10) Need to define top to bottom parallelity. Tolerances for cask straightness. Information needed for final design of cask loading station. 
WHC-SD-FF-DRR-00018

Rev. 0

\section{OTHER}

1) The DAR needs to demonstrate that the design of the ISC complies with 10CFR72 (Specification section 3.3.). Specifically state in report how the features for the ISC agree with NRC acceptable designs or analyses.

2) The Design Criteria section constantly refers to the Spec. It would help if they were clearly specified.

3) WHC requests that the computer output be put in Appendices at the back of the report to improve the ability to find items. If this impacts GA methods on this report. WHC requests a more formatted final report to improve ability to find items. 
WHC-SD-FF-DRR-00018

Rev. 0

\section{ATTACHMENT}

\section{Response and Resolution of WHC Comments}

For comments refer to WHC Treliminary Design Review Comunents $(2 / 14 / 94)$.

\section{THERMAL}

1. As stated in the report, for the final analysis we will perform a transicnt run in which the hourly variations of worst-case ambient conditions (temperature and solar radiation) given in WHC-S-4110 are included. The transient will be run for a suffidently long time to achieve quasi-steady-state. This will provide surface temperature variations. The large thermal mass of the cask assures that the liner and interior cuncrete temperatures are driven by average ambient conditions and will not be influenced by these fluctuations.

The Topical Safety Analysis Report for the Ventilated Slorage Cask (VSC) designed by Pacific Sicrsa Nuclcar Corporation and licensed by the NRC utilized 24-hr average ambient conditions to prodict internal temperatures. For surface temperature variations, a separate 12 -hr transicnt analysis of the concrete shell was performed. GA's analysis will go beyond this by performing a full trangient analysis on the entire cask.

2. To account for directionally-dependent solar radiation, $\mathrm{GA}$ will either perform an $\mathrm{r}-\theta$ analysis at the ISC mid plane or conservatively use the direction of maximum solar input in the r-i model.

3. The variation of thermal conductivily wilh lemperature lias already been accounted for in the air and argon properties. The carbon stet and cuncrete conductivities have very small variations over the range of lemperatures in qucstion and may bc taken constant. This will be explained in the final report.

4. These properties will be given in the final roport.

5. The concrete is a standard mix and the conductivity used is the same or less than values given in Fig. 1-12, "Iemperature and Concrete", ACI publication 25, 1968. This will be documented in the final report.

6. The paint combustion, If It does occur, will contribute a negligible amount of heat compared tu that of the fire. This will be stated in the final report. Data from WHC will be used to confirm this.

7. The flow lengths, areas, hydraulic diameters, loss coefficients, and friction facturs for the flow analysis were all presented in a table on $p$. 4-48. We will provide a flow diagram for the final report. Since the radius ratio of the flow channel is $12 / 12.5=0.96$, the error introduced by assuming parallel plates vs. cylindrical 
annulus is negligible (see Handbook of Heat Transfer, 1973, Chapter 7, Tables 17 and 18$)$.

8. We have used a cask spacing of approximately $5.5 \mathrm{ft}$ based on the number of casks and the pad area given in WHC-S-4110. We will give the minimum required spacing in the final report.

9. The CCC axial heat load profile given. Howcver, intcgration of this curve gives a total heat generation of $1750 \mathrm{~W}$. Thus, we will scale the curve by the ratio of $1500 / 1750$ which is 0.857 .

Regarding the instructions not to include mass or conduction effects, WHC-S-4110 (Sec. 3.2.2.3) requires the calculation of an internal pressure. We cannot perform this calculation without a knowledge of the internal temperature. which requires the CCC thermal conductance. Since WHC did not provide the thernal and physical properties for the CCC as discussed in the neting, we will use the new core component container (CCC) Drawing I -4-72005 Rev. 0 (unreleased) to calculate or model the conductance.

10. The contact coefficient was an estimated value. A reduction from $\mathbf{5 0 0}$ to 50 produced no effect on maximum cask temperatures. The coefficient used for the final report will be documented.

11. The thermal model is shown in Fig. 4-4 and will be augmented with boundary conditions. We will show the nodal subdivision (gridlines) on a separate figure and will delete the computer listings of the input flles if these are not desired.

12. Nute that two different editions of the Handbook of Heab Transfer were referenced. Copies of applicable pages are provided as Attachment 1.

13. The validation report was provided to WHC together with the other codes used.

14. As mandated in Subpart $F$ of 10 CFR 72.122(b)(2)(i), we will cvaluate the cask for the most scvere normal conditions presented in WHC-S-1110. (See response to comment no. 1.) We have also performed a fire analysis per $72.122(\mathrm{c})$ which will be combined with worst-case initial conditions for the final report.

15. The flow rate through the annulus is calculated on the basis of natural convection, i.e., a density difference, and is therefore a passive phenomenon. This "chimney effect" induces a velocity in the annulus sufficlent to cause the square of the Reynolds number to exceed the Grashof number. By the criterion given in Holman, Heat Transfer, p. 295, the local heat transfer thus appears as forced convection.

For preliminary design, GA used the average wind spced of 8 MPH given in WHC-S-4110 to calculate the external heat transfer coefficient. This implies forced convection since the Reynolds number $\approx 300,000$. We are evaluating the effect of no wind in the calculations. 
WHC-SD-FF-DRR-00018

Rev. 0

16. This will be discussed in the final design report.

17. The ash prevents convective cooling in the sense that the ventilation ducts are assumed plugged, and the top surface is assumed covered with gufficient ash to eliminate any heat transfer. Howcver, convective cooling from the external surfaces still occurs. As stated in the report, the effective heat transfer coefficient from the concrete to the air is reduced by $10 \%$ to simulate an ash layer of 0.1 in. adhering to the side. For the final report, we will determine the transient heat-up time to steady-state conditions with ash accumulation.

18. The thermal evaluation assumes a minimum cask spacing of $5.5 \mathrm{ft}$. There are no additional requirements fur shielding consideration. This is also the minimum spacing desired for operations and maintenance.

\section{SIIIILDING COMMENTS}

1. The cquation is developed based on albedo theory for both reutrons and gammas. The equations used to derive equation 7.10-8 are independent of particle (neutral particles) type. The particle type (and energy) is taken into account by the albcdo $\left(\mathrm{A}_{2}\right)$. Shaeffer's text is primarily concerned with neutrons as it is a reactor shielding text. The text however also includes a discussion on gamma scattering through ducts which refers back to the neutron equations but uses the gamma albedo. The albedo used in our analysis was specifically for $1.25 \mathrm{MeV}$ gammas which is what we have in the fuel end fittings. Shaeffer's text also presents experimental results for both neutron and gamma albedo scattering to validate albedo theory.

2. During final design, we will model the ducl and delemine the dose rates on the surface of the cask from direct radiation. If the current design provides inadequate shielding, the last leg of the duct will be rotated $20^{\circ}$ so no direct shine is possible.

3. As stated in Section 5.4.1 we will model cach driver assembly individually in final design.

4. Yes, we have submitted the validation reports for WHC. information.

5. Loss of water is not expected to be significant on a massive concrete structure as the 1SC.. Any loss will occur in the outer layer of the concrete and will fluctuate with the weather. In order to take into account the loss of water over the 50-year storage period, we will need time-dependent neutron and gamma source terms for the fueler region. It should also be noted that the neutron contribution to the total duse rate is minimal. Even a doubling of the neutron dose rate will not result in a significant increase in the total dose rate at the surface of the cask. $C \Lambda$ will add justification to DAR. 
WHC-SD-FF-DRR-00018

Rev. 0

6. The cask used in the shielding calculations is the 117,010 lb cask. The total weight of the shielding model however is much less than this, since we used minimum expected material conditions in our analysis.

\section{STRUCTURAL}

1. GACAP was used only for the oblique drops, in which the load is applied only at one end. GACAP was not used for the side drop since the application of the load at each end would not be appropriate. The analysis of the side drop and slapdown impacts was done separately using strength of material calculations.

As explained in the meeting, the computer codes have not been verified and/or benchmarked by tests, analyses or evaluations of concrete containers.

ILMOD is a purely geometrical code. It calculates the area of the footprint at different angles and crush depths and multiplies the area by the concrete compressive crush strength. ILMOD is used instead of calculating the area by hand.

SAC is used only to calculate the flange/cylinder stresses. It has been validated for this type of calculation.

As explained earlier, ' 'AC'Al' is used to calculate the cask response during oblique drops. Only the dynamic behavior and forces developed are used. The adequacy of the concrete section to withstand loads is evaluated separately per ACI methods.

The verification documents have been forwarded to WHC.

2. Both 3.2.2.8.2(3) and (4) of WHC-S-4110 require evaluation of drops on a horizontal concrete surface. Per WHC instructions, the analysis for (3) was conservatively done for an unyiclding surfacc. The 1-ft-thick concrete slab design used for (4) was also provided by WHC. It should be a conservative model of the concrete storage pad. GA can neither justify WHC's data nor determine the intent of WHC's specification.

The final design will address the effects of variations in the ISC: concrete properties. The target parameters were provided by WHC.

3. An importance factor of 2 will be used in the final design.

4. An appendix showing NRC, ,eviously accepled concrele temperature data will be included in the final design report. This information was previously provided to WFIC in the discussion of a proposed design without ducts. No reduction in concrete material propertics is required at the operating temperatures. 
WHC-SD-FF-DRR-00018

Rev. 0

The maximum steel temperature is used to set the steel containment allowables. The ASME temperature properties are used for this purpose. WHC will review the concrete spedfication prior to fabrication.

5. The effect of freeze/ lhaw cycles will be discussed in the final design report.

6. Screens and a slight incline are provided for the ducts to minimize the likelihood of water, dirt or debris blocking the vents as is shown on the drawings. The case of the blocked vents was analyzed as an accident or off-normal condition.

Corrosion has been discussed in the preliminary design. The expected corrosion is minimal, and it does not take into account the presence of paint. for the safety related steel components, degradation of the paint will also be minimal because no damaging sun light wlll impinge on 1 t. There is no need to perform any maintenance activities to cupe with paint degradation on the annulus surfaces.

7. All structural welds are full penelration. See discussion of welded port cover.

8. An expanded discussion of the load path will be provided in the final design report, as well as the interface loads with the CCC.

9. The altemative design rules in NC-3217 allow the use of $S_{m}$ rather than $S$ (design by rule allowables) in NC 3131 . Reg. Guide 7.6 also uses $S_{m}$ rather than $S$.

10. Subsection NB was used to be conservative, but to be consistent Subsection NC will be referenced.

11. GA will update references to 1990 edition of [JC.RT. -1.5911 .

12. Agree.

13. The material properties will be added.

14. WHC is going to provide GA with the necessary information to analyze or delemine if an already analyzed event bounds accidental drop of a portable crane onto the ISC.

15. During preliminary dcsign, GA evaluated the cask for the effect of differential thermal expansion in the vertical direction only since the effect is most severe in that direction. During final design GA will perform the thermal stress analysis in the circumferential direction. In that direction, the thermal loading on the studs is small and the stresses in the concrete will be similar in magnitude to the stresses in the longitudinal direction.

16. GA will add a statement in the final design report discussing the expected lack of significant damage on the concrete structure due to thermal cycling, thawing and freezlng. Thermal cycling due to daily temperature variations will only affect the outer few inches of the concrete and will not cause any fatigue failure. The temperature variations from winter to summer will only result in a change in the 
differental temperature between the outside and inside surfaces by approximately $7^{\wedge} \mathrm{F}$ (I Jelta $I^{\prime}=47^{\wedge}$ in summer and $\Delta \mathrm{T}^{\prime}=40^{\mathrm{H}} \mathrm{F}$ in winter). This change in differential temperature will only change the thermal stresses through the cask wall a small amount. Since there are only one cycle each year, fatigue is not a concern. There will not be any accumulation of deformation due to the cycling. The only long lerm effect is creep which over time will continuously reduce thermal stresses and result in a small amount of axial deformation. Sorne cracking of the concrete may occur without affecting the structural integrity of the cask. Pcriodic inspection and maintenance of the cask will be done to monitor cask surface conditions.

17. The fire results in a high thermal gradient at the outer surface and will not drastically affect the thermal stresses through the wall since there is no nther significant loading on the cask during a flre except dead load. There may be some spalling of the outer surface concrete. GA will include this in the DAR.

18. Agree. GA is evaluating the effect of the newly provided $C C C$ information regarding weight range, not included in WI IC-S-4110. A new impact limiter design will be required. See response to the Action Items.

19. There are no external impact limitcrs for the ISC.

20. Agree.

21. All hard copies are provided in the appendices.

22. The nomal condition bolting allowables are widely accepted and conservattvely based on ASME B and PV Code Section III, Subsection NB. These allowables will prevent any leakage froin the cask.

23. The basis for the ISC design are the calculations presented in the preliminary design report. WIIC requested that we discuss previous designs that have been accepted by the NRC and, therefore, we provided the information on what has been done in other designs. Both the contents and the design requirements of the ISC arc uniquc. Therefore, previously licensed designs can be discussed for information but, the ISC design must stand on its own merits, and not as a subset of a previous design.

\section{QPERATIONS AND INTERFAC'ES}

1. $C_{3} A$ will use double metal seals between the closure and the flange with a tapped hole between the two seals to allow for easier leak checking and cap'stility fur monitoring. In addition, GA will use a double welded cover for the gas sample quick conntect. These welded covers meel the requirement in WIIC-S-4110 Section 3.2.5.4. See the attached discussion of the welded port cover for further information. 
WHC-SD-FF-DRR-00018

Rev. 0

2. The cask is required to be leak tight per WHC-S-4110. ANSI N14.5-1987 defines leak tight as a leakage $S 1 \times 10^{-7} \mathrm{std} \mathrm{cm}^{3} / \mathrm{sec}$ (air) with an upstream pressure of $1 \mathrm{~atm}$ and a downstream pressure of 0.01 atm or less. Filling the cask to 5 psig (1.34 atm) meets the upstream condition and the mass spectrometer leak detector pulls a vacuum on the other side. Each cask will also undergo a pressure test at 1.5 times the design pressure which is 75 psig.

2.a. The containment criterion is leak tight as mandated by WHC-S-1110

Section 3.2.5.1. ANSI N14.5-1987 defines leak tight as a leakage of less than $1 \times 10^{-7} \mathrm{std} \mathrm{cm}^{3} / \mathrm{sec}$ (air) with an upstream pressure of $1 \mathrm{~atm}$ and a downstream pressure of 0.01 atm or less.

3. Maintaining an inert atmnsphere inside the ISC. before torquing bolts is not a requirement of the specification and presents a difficult design challenge. GA agreed to perform calculations estimating the amount of leakage that will occur around the metal seals when the closure is resting on the cask, but prior to torquing of the bolts.

4. GA will modify the design to be compatible with the MASF CLS upper restraint. Tolcrances on the interfacing chamfers will be cstablished during final design.

5. We will provide an alignment feature to guide the closure into correct position for bolt alignment.

6. Yes, the lift lugs are removable.

7. The cask interinr is inert, and accordingly there will be no change in interinr dimensions over the $\mathbf{5 0}$ year design llfe. There will be no difficulty in removing the CCC at the end of the cask's design life.

GA is evaluating the CCC/internal inpact limiter interface based on the new CCC design provided. Preliminary calculations of the intemal impact limiter indicate that the reduced CCC footprint requires a thicker plate above the honeycomb than in the previous design. This will require changing the cavity length and consequently the overall cask length, requiring rerunning of analyses already completed. C $\Lambda$ considers this to be a specification change which will have a minor effect on cost and schedule.

8. Tolerances and flatness requirements will be evaluated during final design. The carbon steel plate will be provided with a 32 finish and a surface coating to protect. against corrosion as was agreed at the PDR meeting. The back of the plate will have studs anchored in the concrete, which will assure adequate stiffness and rigldity for sealing.

9. GA needs to resolve WHC's new PDR comments and modify the deslgn based on the revised CCC information. Once the interface information is finalized, the design can be frozen and the interface dimensions controlled. 
WHC-SD-FF-DRR-00018

Rev. 0

10. This will be done during final design, after consultation with fabricators.

\section{OTHER}

1. $\mathrm{C} \Lambda$ will add rcferences to 10CFR72 throughout the final design analysis report (DAR), as appropriate. CA rclics on the WHC-S-4110 specification to define the environmental, suberiticality and handling conditions that apply to the cask operations. GA will cover the requirements on which we have information and those which are applicable. Statements that report how the features for the ISC agree with previous designs or analyses that have been accepted by NKC are not appropriate for the DAR since the contents, operational environment and design requirements of the ISC are unique. Simllarity with previously licensed designs can be discussed in meetings with WHC as desired.

2. We will expand descriptions.

3. CA will follow the outline specified in the proposal, but will number the appendices in each section so that information is easier to find.

\section{WELDED PORT COVER DISCUSSION}

As agreed in the January 31,1994 , Preliminary Design Review meeting, $G A$ is providing a welded cover over the monitoring port. Attached is a sketch of the design. This design closely parallels the design in the NRC-licensed VSC casks. GA would like to make you aware that the welds are fillet welds and not full penelration welds.

GA believes that this is the best design because it minimizes worker exposure, while meeting the regulations. The NRC has exempted seal welds in closures and port covers from mecting $\Lambda$ SME Code requirements becausc: (1) there are two welds in scrics for any lcak path and this redundancy minimizes any risk to the public and (2) the load on the welds is minimal (pressure is small).

Per the specification, the cask is being designed for a puncture on the top of the cask. The size of the port cover is such that only part of the punch can impact the cover. Most of the punch will he hearing on the rest of the closure. There is always the possibility that, during an angled punch, the punch would hit in such a way as to damage part of the outer cover. Again, the redundancy argument is valid. The primary weld for the inner cover will not be damaged. This hypothetical accident condition comes from a 10CFR71 requirement and is not required per 10CFR72. Double welds are not required in 10CFR71. Therefore, it is GA's opinion that the design does not represent a danger to the public or workers and meets the regulatory requirements and your specification.

Please discuss the welded cover design with your technical staff and provide us with any comments you may have. 
WHC-SD-FF-DRR-00018

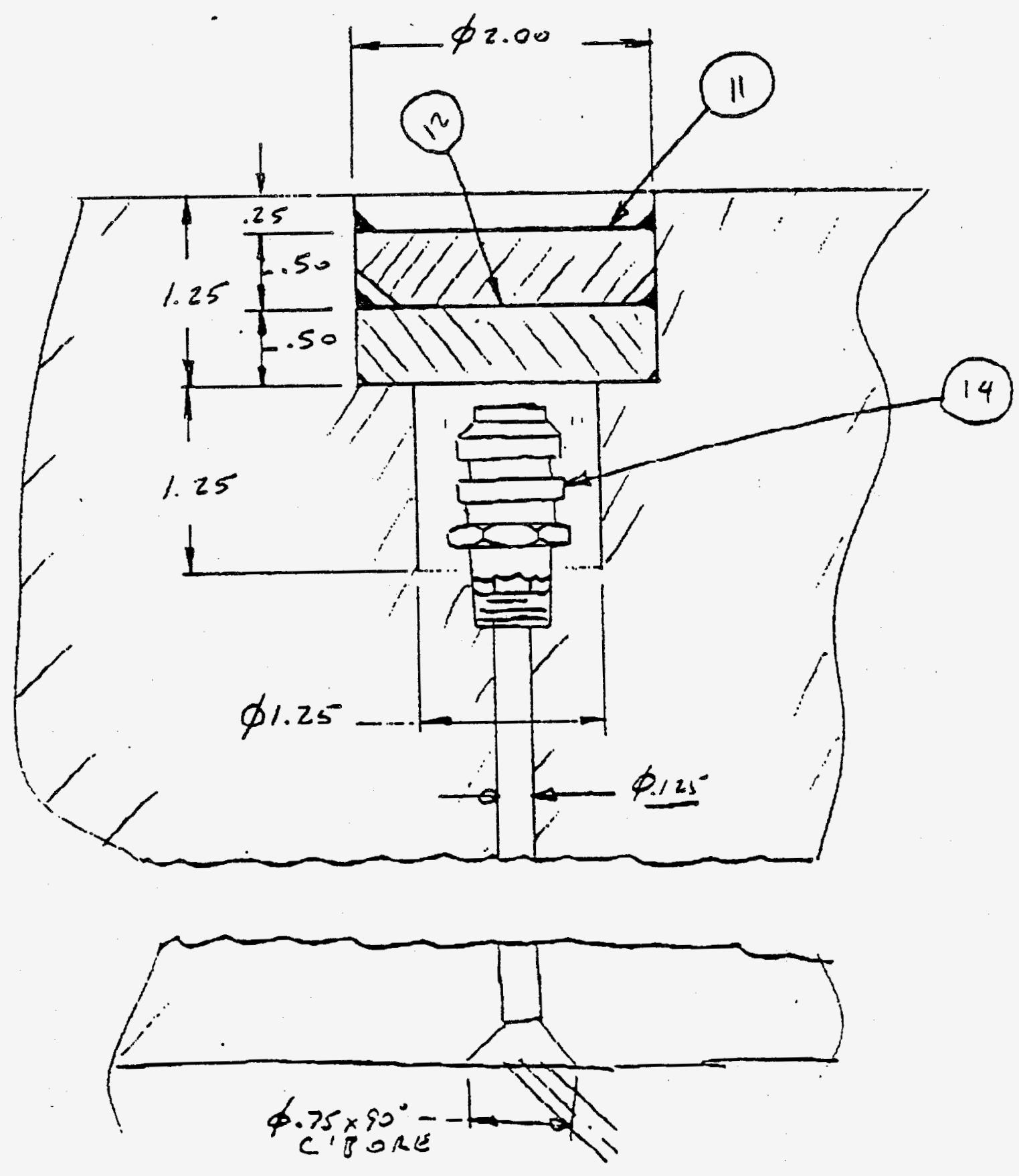

WELDED PORT COVER 
WHC-SD-FF-DRR-00018

Rev. 0

\begin{tabular}{|l|l|l|l|}
\hline \multirow{2}{*}{ REVIEW COMMENT RECORD (RCR) } & $\begin{array}{l}\text { 1. Date } \\
2 / 10 / 94\end{array}$ & $\begin{array}{l}\text { Review No. } \\
\text { Prel iminary }\end{array}$ \\
\cline { 2 - 3 } & 3. Project No. \\
FFTF & $4 . \quad$ Page \\
\hline
\end{tabular}

5. Document Number(s)/title(s)
FFTF SPENT FUEL INTERIM STORAGE CASK
PRELIMINARY DESIGN ANALYSIS REPORT
PRELIMINARY DESIGN ANALYSIS REPORT
6. Program/Project/ Building Number FFTF

7. Reviewer

17. Comment Submittal Approval:

Organization Manager (Optional)
10. Agreement with indicated comment disposition(s)

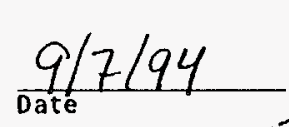

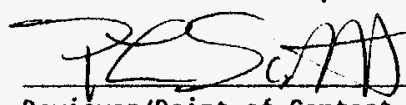

Reviewer/Point of Contact

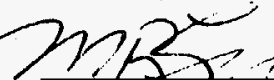

8. Organization/Group

Engineering

Analysis/Facility Stress Analysis
9. Locat ion/Phone

ETC $-2 / H 5-57 /$

$2-1744$

\begin{tabular}{|c|c|c|c|c|}
\hline \multicolumn{5}{|c|}{ Author/originator $\angle E U$} \\
\hline $\begin{array}{l}12 . \\
\text { I tem }\end{array}$ & $\begin{array}{l}\text { 13. Comment(s)/Discrepancy(s) (Provide technical justification for the } \\
\text { comment and detailed recommendation of the action required to correct/ } \\
\text { resolve the discrepancy/problem indicated.) }\end{array}$ & $\begin{array}{l}14 . \\
\text { Hoid } \\
\text { Point }\end{array}$ & 15. Disposition (Provide justification if MOT accepted.) & $\begin{array}{l}16 . \\
\text { status }\end{array}$ \\
\hline & $\begin{array}{l}\text { The review is based on the requirements specified by } \\
\text { WHC-S- } 4110 \text {, Rev. 3, Specification for FFTF Interim } \\
\text { Storage Cask. }\end{array}$ & & & \\
\hline
\end{tabular}


Rev 0

\begin{tabular}{|c|c|c|c|}
\hline & \multirow{2}{*}{ REVIEW COMMENT RECORD (RCR) } & $\begin{array}{l}\text { 1. Date } \\
2 / 10 / 94 \\
\end{array}$ & $\begin{array}{l}\text { 2. Review No. } \\
\text { Prel iminary }\end{array}$ \\
\hline 1 & & $\begin{array}{l}\text { 3. Project No. } \\
\text { FFTF }\end{array}$ & 2 of 7 \\
\hline
\end{tabular}

12. 13. Comment(s)/Discrepancy(s) (Provide technical justification for the Item comment and detailed recommendation of the action required to correct/ resolve the discrepancy/problem indicated.)

1. Computer codes ILMOD, GACAP, and SAC: The vendor states that GACAP is verified against the DYNA3D and SCANS computer codes. SCANS is useful for circular steel containers with dumb-bell type impact

limiters. Is the application of GACAP suited to concrete containers? Please provide the technical basis for the use of all computer codes and provide evidence that these codes have been verified and/or benchmarked by tests or analyses of evaluation of concrete containers. Are the codes that are being used to make design decisions recognized by industry and are they intended for use as design tools?

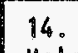

14. \begin{tabular}{l} 
Hold \\
Point \\
\hline
\end{tabular}

15. Disposition (Provide justification if NOT accepted.)

GACAP was used only for the oblique drops, in which the load is applied only at one end. GACAP was not used for the side drop since the application of the load at each end would not be appropriate. The analysis of the side drop and slapdown impacts was done separately using strength of material calculations.

As explained in the meeting, the computer codes have not been verified and/or benchmarked by tests, analyses or evaluations of concrete containers.

ILMOD is a purely geometrical code. It calculates the area of the footprint at different angles and crush depths and multiplies the area by the concrete compressive crush strength. ILMOD is used instead of calculating the area by hand.

SAC is used only to calculate the flange/cylinder stresses. It has been validated for this type of calculation.

As explained earlier, GACAP is used to calculate the cask response during oblique drops. Only the dynamic behavior and forces developed are used. The adequacy of the concrete section to withstand loads is evaluated separately per ICI methods.
16. 
WHC-SD-FF-DRR-00018

Rev. 0

\begin{tabular}{|l|l|l|}
\hline \multirow{2}{*}{ REVIEW COMMENT RECORD (RCR) } & $\begin{array}{l}\text { Date } \\
2 / 10 / 94\end{array}$ & $\begin{array}{l}2 . \text { Review No. } \\
\text { Preliminary }\end{array}$ \\
\cline { 2 - 4 } & 3. Project No. \\
FFTF & 4. Page \\
\hline
\end{tabular}

12. 13. Comment( $s$ )/D iscrepancy(s) (Provide technical justification for the

Item comment and detailed recommendation of the action required to correct/ resolve the discrepancy/problem indicated.)

2. Load Paths: Please provide a discussion of the load paths for the various storage cask loading conditions. Explain the load path through the structural welds and shear studs, and address what load is distributed among these components. Also, please discuss the interface loads of the payload support structure with the ISC containment.

3. Effects of Temperature on Concrete: Please provide a detailed discussion of the maximum thermal stresses and maximum and minimum temperatures of the various ISC structural components (steel and concrete) and the associated reduction in mechanical properties at the extreme temperature limits. This discussion should be concerned with showing conformance with the stipulated codes requirements and provisions. Also, since the ISC design will most likely be finalized before the concrete mix design is selected, please address how the variations in concrete properties will be accounted for and controlled in the design mix selection and verification process.

4. Stress Analyses: Please provide a discussion of the stresses resulting from the various loading conditions, particularly the stresses (longitudinal and circumferential) in the steel and concrete resulting from thermal expansion and temperature gradients.

\begin{tabular}{|c|c|c|}
\hline $\begin{array}{l}14 \\
\text { Hoid } \\
\text { Point } \\
\end{array}$ & 15. Disposition (Provide justification if NOT accepted.) & $\begin{array}{l}16 . \\
\text { Status }\end{array}$ \\
\hline & $\begin{array}{l}\text { An expanded discussion of the load path will } \\
\text { be provided in the final design report, as } \\
\text { well as the interface loads with the CCC. }\end{array}$ & \\
\hline & $\begin{array}{l}\text { An appendix showing NRC previously accepted } \\
\text { concrete temperature data will be included } \\
\text { in the final design report. The information } \\
\text { was previously provided to WHC in the } \\
\text { discussion of a proposed design without } \\
\text { ducts. No reduction in concrete material } \\
\text { properties is required at the operating } \\
\text { temperatures. } \\
\text { The maximum steel temperature is used to set } \\
\text { the steel containment allowables. The ASME } \\
\text { temperature properties are used for this } \\
\text { purpose. WHC will review the concrete } \\
\text { specification prior to fabrication. }\end{array}$ & \\
\hline & Agree & \\
\hline
\end{tabular}


WHC-SD-FF-DRR-00018

Rev。 0

\begin{tabular}{|c|l|l|l|}
\hline \multirow{2}{*}{ REVIEW COMMENT RECORD (RCR) } & $\begin{array}{l}\text { 1. Date } \\
2 / 10 / 94\end{array}$ & $\begin{array}{c}\text { Review No. Prel iminary } \\
\text { 3. Project No. } \\
\text { FFTF }\end{array}$ & $\begin{array}{l}4 . \text { Page } \\
4\end{array}$ \\
\hline
\end{tabular}

\begin{tabular}{|c|c|c|c|c|}
\hline $\begin{array}{l}12 . \\
\text { Item }\end{array}$ & $\begin{array}{l}\text { 13. Comment(s)/Discrepancy(s) (Provide technical justification for the } \\
\text { corment and detailed recommendat ion of the action required to correct/ } \\
\text { resolve the discrepancy/problem indicated.) }\end{array}$ & $\begin{array}{l}14 . \text { id } \\
\text { Hoid } \\
\text { Point }\end{array}$ & 15. Disposition (Provide justification if NOT accepted.) & $\begin{array}{l}16 . \\
\text { status }\end{array}$ \\
\hline 5 & $\begin{array}{l}\text { Analyses Data: The final stress analysis } \\
\text { documentation package should contain hard copies of } \\
\text { all input data, post processing commands, and any } \\
\text { data extracted from the computer output that is used } \\
\text { in the analysis (e.g, tables, graphs, plots, etc.) }\end{array}$ & & $\begin{array}{l}\text { All hard copies are provided in the } \\
\text { appendices. }\end{array}$ & \\
\hline 6. & $\begin{array}{l}\text { Vents: Please identify what provisions have been } \\
\text { made to prevent water, dirt, and debris from } \\
\text { blocking the yents? What increase in temperature } \\
\text { would result if blockage of the vents occurred? } \\
\text { Please address the possibility and consequences of } \\
\text { corrosion in the vented annulus region between the } \\
\text { containment and shielding (particularly for low heat } \\
\text { load conditions). What maintenance activities can } \\
\text { be performed to cope with degradation of the paint } \\
\text { on the annulus surfaces. }\end{array}$ & & $\begin{array}{l}\text { Screen and a slight incline are provided for } \\
\text { the ducts to minimize the likelihood of } \\
\text { water, dirt or debris blocking the vents as } \\
\text { is shown on the drawings. The case of the } \\
\text { blocked vents was analyzed as an accident or } \\
\text { off-normal condition. Corrosion has been } \\
\text { discussed in the preliminary design. The } \\
\text { unexpected corrosion is minimal, and it does } \\
\text { not take into account the presence of paint. } \\
\text { For the safety related steel components, } \\
\text { degradation of the paint will also be } \\
\text { minimal because no damaging sun light will } \\
\text { impinge on it. There is no need to perform } \\
\text { any maintenance activities to cope with } \\
\text { paint degradation on the annulus surfaces. }\end{array}$ & \\
\hline 7. & $\begin{array}{l}\text { Welds: All structural fillet welds should be full } \\
\text { penetration welds. }\end{array}$ & & $\begin{array}{l}\text { All structural welds are full penetration. } \\
\text { See discussion of welded port cover. }\end{array}$ & \\
\hline
\end{tabular}


WHC-SD-FF-DRR-00018

Rev. 0

\begin{tabular}{|c|c|c|}
\hline EYICIA COMMALMT DE & \begin{tabular}{|l} 
1. Date \\
\\
\end{tabular} & $\begin{array}{l}\text { 2. Review No. } \\
\text { Preliminary }\end{array}$ \\
\hline 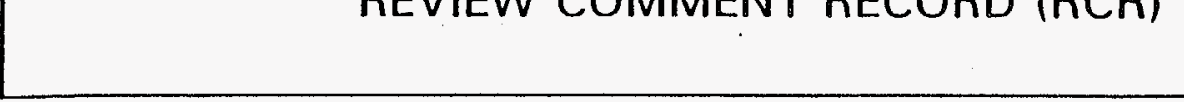 & $\begin{array}{l}\text { 3. Project No. } \\
\text { FFTF }\end{array}$ & $\begin{array}{l}\text { 4. Page } \\
\end{array}$ \\
\hline
\end{tabular}

\begin{tabular}{|c|c|c|c|c|}
\hline $\begin{array}{l}12 . \\
\text { Item }\end{array}$ & $\begin{array}{l}\text { 13. Comment(s)/Discrepancy(s) (Provide technical justification for the } \\
\text { corment and detailed recormendation of the action required to correct/ } \\
\text { resolve the discrepancy/problem indicated.) }\end{array}$ & $\begin{array}{l}14 \\
\text { Hoid } \\
\text { Point }\end{array}$ & 15. Disposition (Provide justification if NOr accepted.) & $\begin{array}{l}16 . \\
\text { Status }\end{array}$ \\
\hline 8. & $\begin{array}{l}\text { ASME Criteria: The ISC Design Specification } \\
\text { stipulates that the containment vessel is to be } \\
\text { designed in accordance with ASME Section III, Class } \\
2 \text { requirements. It appears that Class } 1 \text { ( } \mathrm{S}_{\mathrm{m}} \text { values) } \\
\text { are being used in the design analysis. Paragraph } \\
\text { NCA-2134 (Optional Use of Code Classes) of the ASME } \\
\text { Code does state that Class } 2 \text { items may be } \\
\text { constructed as Class } 1 \text { items. It is implied, } \\
\text { however, that one must accept all of the } \\
\text { requirements of Class } 1 \text { (e.g. material pedigree, } \\
\text { design equations, quality assurance, inspection, } \\
\text { fabrication procedures) if the item is analyzed as a } \\
\text { Class } 1 \text { item. Therefore, please provide further } \\
\text { justification for the use of Class } 1 \text { material } \\
\text { allowables (S values) rather than Class } 2 \text { allowables } \\
\text { (S values). }\end{array}$ & & $\begin{array}{l}\text { The alternative design rules in } N C-3217 \\
\text { allow the use of } S_{m} \text { rather than S(design by } \\
\text { rule allowables) in } N C-3131 \text {. Reg. Guide } 7.6 \\
\text { also uses } S_{m} \text { rather than } S \text {. }\end{array}$ & \\
\hline
\end{tabular}


WHC-SD-FF-DRR-00018

Rev. 0

\section{REVIEW COMMENT RECORD (RCR)}

1. Date
$2 / 10 / 94$

3. Project No.

2. Review No. Preliminary

4. Page

FFTF

6 of 7

12. 13. Comment(s)/D iscrepancy(s) (Provide technical justification for the comment and detailed recomendation of the action required to correct/ resolve the discrepancy/problem indicated.)

9. Drop Analysis: Paragraphs 3.2.2.8.2(3) and (4) of WHC $-5-4110$ require drops on a horizontal concrete surface.- Please provide technical justification to show that the 1-ft-thick concrete slab used in the design calculations provides sufficient rigidity and mass to meet the specifications intent. Also, the final design analysis should address the effects of variations in concrete properties on the lynamic response of the ISC and target.

\begin{tabular}{|c|c|c|}
\hline $\begin{array}{l}14 . \\
\text { Hold } \\
\text { Point }\end{array}$ & 15. Disposition (Provide justification if NOT accepted.) & $\begin{array}{l}16 . \\
\text { status }\end{array}$ \\
\hline & $\begin{array}{l}\text { Both } 3.2 .2 .8 .2(3) \text { and (4) of WHC-S-4110 } \\
\text { require evaluation of drops on a horizontal } \\
\text { concrete surface. Per WHC instructions the } \\
\text { analysis for (3) was conservatively done for } \\
\text { an unyielding surface. The } 1-f t \text { thick } \\
\text { concrete slab design used for (4) was also } \\
\text { provided by WHC. It should be a } \\
\text { conservative model of the concrete storage } \\
\text { pad. ( } 8 \text { inch thick concrete slab at storage } \\
\text { pad, WHC provided I foot thickness } 4000 \text { psi } \\
\text { concrete slab with the approval of } \\
\text { Transportation and Packaging since they } \\
\text { requested this drop condition) GA can } \\
\text { neither justify WHC's data nor determine the } \\
\text { intent of WHC's specification. } \\
\text { The final design will address the effects of } \\
\text { variations in the ISC concrete properties. } \\
\text { The target parameters were provided by WHC. }\end{array}$ & \\
\hline & $\begin{array}{l}\text { An importance factor of } 2 \text { will be used on } \\
\text { the final design }\end{array}$ & \\
\hline & $\begin{array}{l}\text { The effects of freeze/thaw cycles will be } \\
\text { discussed in the final design report. }\end{array}$ & \\
\hline
\end{tabular}

Seismic Analysis: Per paragraph 3.2.2.8.4 of WHC-S-4110, an Importance Factor of 2.0 should be used in seismic analyses. The preliminary design does not account for the importance factor. Please address this: ssue.

11. Freeze/Thaw Cycles: Please address the concrete properties at cold temperatures and how these may affect long-term performance of the ISC? (See comment 4 . above). Also, please discuss how the design can accommodate repeated cycles of freezing and thawing. 
WHC-SD-FF-DRR-00018

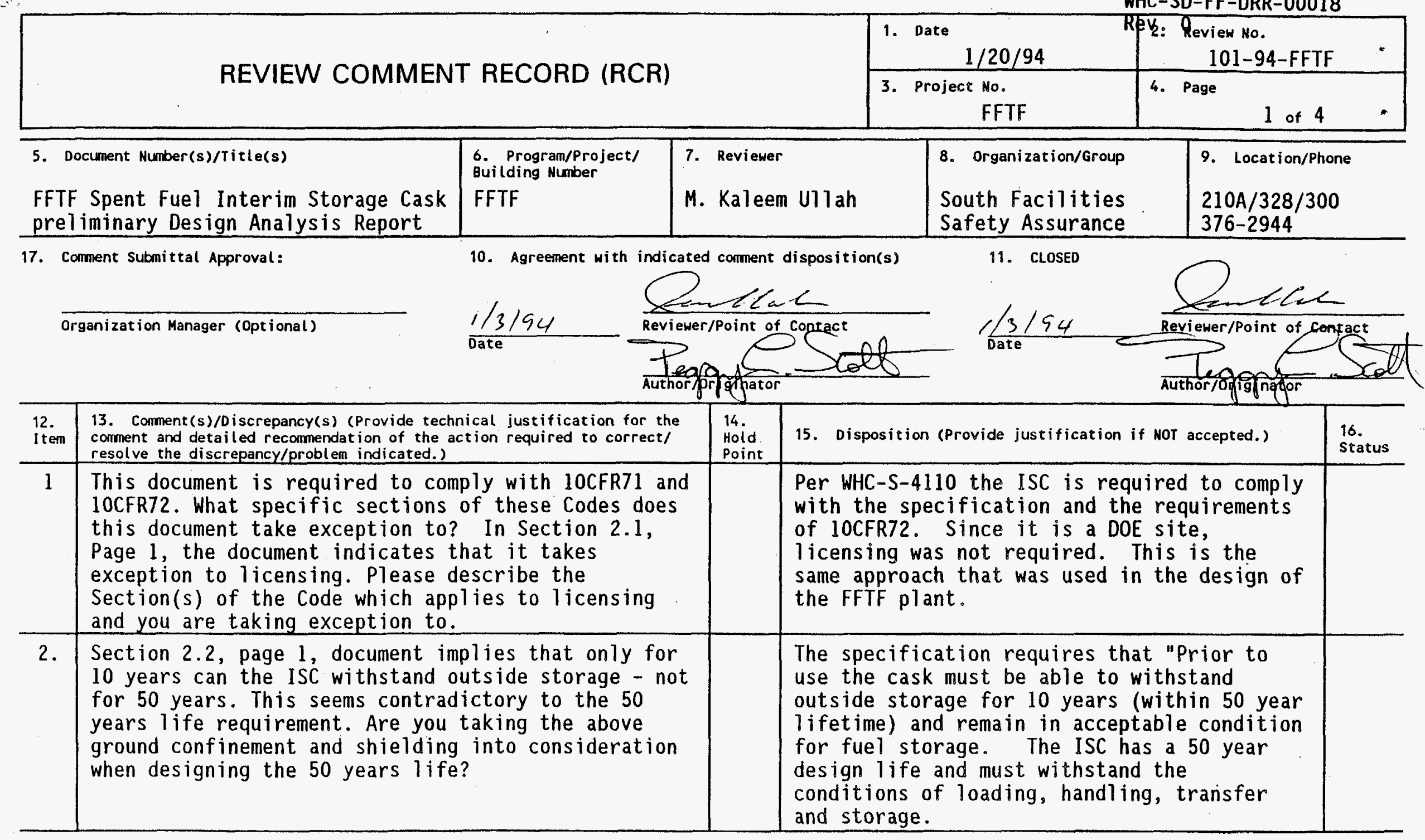




\section{REVIEW COMMENT RECORD (RCR)}

\begin{tabular}{|c|}
\hline $\begin{array}{l}\text { 1. Date } \\
1 / 20 / 94\end{array}$ \\
\hline $\begin{array}{c}\text { 3. Project No. } \\
\text { FFTF }\end{array}$ \\
\hline
\end{tabular}

101-94-FFTF

2 of 4

\begin{tabular}{|c|c|c|c|c|}
\hline $\begin{array}{l}12 . \\
\text { Item }\end{array}$ & $\begin{array}{l}\text { 13. Corment(s)/Discrepancy(s) (Provide technical justification for the } \\
\text { comment and detailed recommendation of the action required to correct/ } \\
\text { resolve the discrepancy/problem indicated.) }\end{array}$ & $\begin{array}{l}14 . \\
\text { Hoid } \\
\text { Point }\end{array}$ & 15. Disposition (Provide justification if Nor accepted.) & $\begin{array}{l}\text { 16. } \\
\text { status }\end{array}$ \\
\hline 3. & $\begin{array}{l}\text { Section 2.3, page } 1 \text {, and Thermal Evaluation Section } \\
4.0 \text {, page 4-6: the calculations are based on time- } \\
\text { averaged temperature of the outside environment of } \\
94 \mathrm{~F} \text {. The 10CFR72, subpart } \mathrm{F}, 72.122(\mathrm{i}) \text {, requires } \\
\text { that "Most severe of the natural phenomena reported } \\
\text { for the site and the surrounding area" be } \\
\text { considered. In this case, WHC-S-4110, page } 21 \text {, Table } \\
1 \text {, gives most severe environment temperature of } 115 \\
\text { F. Although I do not believe that this fits the } \\
\text { "MOST SEVERE" definition, but comes so close that it } \\
\text { would be wise to use it and perform the } \\
\text { calculations. However, Battelle' Meteriological data } \\
\text { report for the Hanford site gives outside most } \\
\text { severe temperature of } 122 \mathrm{~F} \text { or higher. Please check. }\end{array}$ & & $\begin{array}{l}\text { The specification requires } 115^{\circ} \mathrm{F} \text {. As } \\
\text { mandated in Subpart } F \text { of } \\
\text { 10CFR72.122(b)(2)(i) GA will evaluate the } \\
\text { cask for the most severe normal conditions } \\
\text { presented in WHC-S-4110. For the final } \\
\text { analysis GA will perform a transient run is } \\
\text { which the hourly variations of worst-case } \\
\text { ambient conditions (temperature and solar } \\
\text { radiation) given in WHC-S-4110 are included. } \\
\text { The transient will be run for a sufficiently } \\
\text { long time to achieve quasi-steady-state. } \\
\text { This will. provide surface temperature } \\
\text { variations. The large thermal mass of the } \\
\text { cask assures that he liner and interior } \\
\text { concrete temperatures are driven by average } \\
\text { ambient conditions and will not be } \\
\text { influenced by these fluctuations. } \\
\text { GA has also performed a fire analysis per } \\
72.122 \text { (c) which will be combined with worst } \\
\text { case initial conditions for the final } \\
\text { report. }\end{array}$ & \\
\hline
\end{tabular}




\begin{tabular}{|c|c|c|}
\hline & $\begin{array}{l}\text { 1. Date } \\
1 / 20 / 94\end{array}$ & $\begin{array}{l}\text { Rev ReAfew No. } \\
\text { 101-94-FFTF }\end{array}$ \\
\hline REVIEV CUIVIVIENI RELURD IR & $\begin{array}{l}\text { 3. Project Ho. } \\
\text { FFTF }\end{array}$ & $\begin{array}{l}\text { 4. Page } 3 \text { of } 4 \\
\text { n }\end{array}$ \\
\hline
\end{tabular}

\begin{tabular}{|c|c|c|c|c|}
\hline $\begin{array}{l}12 . \\
\text { Item }\end{array}$ & $\begin{array}{l}\text { 13. Corment(s)/Discrepancy(s) (Provide technical justification for the } \\
\text { corment and detailed recormendation of the action required to correct/ } \\
\text { resolve the discrepancy/problem indicated.) }\end{array}$ & $\begin{array}{l}14 . \\
\text { Hold } \\
\text { Point }\end{array}$ & 15. Disposition (Provide justification if NOT accepted.) & $\begin{array}{l}16 . \\
\text { Status } \\
\end{array}$ \\
\hline 4. & $\begin{array}{l}\text { Comment is related to Thermal Evaluation: All heat } \\
\text { dissipation i: based on Natural Convection and } \\
\text { passive cooling. I cannot justify-forced convection } \\
\text { modelling. with constant wall temperature as has been } \\
\text { assumed on Page } 4-6 \text {, of Thermal Evaluation section. } \\
\text { It may also be pointed out that daily average wind } \\
\text { of } 8 \text { mph, does not justify forced convection } \\
\text { modelling either. I hope "Mother Nature" can be used } \\
\text { as a design criteria to assure an } 8 \text { mph wind to cool } \\
\text { the cask. }\end{array}$ & & $\begin{array}{l}\text { The flow rate through the annulus is } \\
\text { calculated on the basis of natural } \\
\text { convection, i.e., a density difference, and } \\
\text { is therefore a passive phenomenon. This } \\
\text { "chimney effect" induces a velocity in the } \\
\text { annulus sufficient to cause the square of } \\
\text { the Reynolds number to exceed the Grashof } \\
\text { number. By the criterion given in Holman, } \\
\text { Heat Transfer, p. } 295 \text {, the. local heat } \\
\text { transfer thus appears as forced convection. } \\
\text { For preliminary design, GA used the average } \\
\text { wind speed of } 8 \text { MPH given in WHC-S-4110 to } \\
\text { calculate the external heat transfer } \\
\text { coefficient. This implies forced convection } \\
\text { since the Reynold's number =300,000. GA is } \\
\text { evaluating the effect of no wind in the } \\
\text { calculations. }\end{array}$ & \\
\hline 5 . & $\begin{array}{l}\text { Leak Testing, Section } 1.2 .3 \text {, page } 4 \text {. The Cask is } \\
\text { known to have or develop an internal pressure of } 50 \\
\text { psig. The document indicates that the integrity of } \\
\text { the seals and the Cask is to be tested only to } 5 \\
\text { psig. I cannot find explanation anywhere why? please } \\
\text { clarify. } \\
\end{array}$ & & $\begin{array}{l}\text { The cask is required to be leak tight per } \\
\text { WHC-S-4110. ANSI N14.5-1987 defines leak } \\
\text { tight as a leakage } 1 \times 10.7 \text { std } \mathrm{cm}^{3} / \mathrm{sec} \\
\text { (air) with an upstream pressure of } 1 \text { atm and } \\
\text { a downstream pressure of } 0.01 \text { atm or less. } \\
\text { Filling the cask to } 5 \text { psig }(1.34 \text { atm) meets } \\
\text { the upstream condition and the mass } \\
\text { spectrometer leak detector pulls a vacuum on } \\
\text { the other side. Each cask will also undergo } \\
\text { a pressure test at } 1.5 \text { times the design } \\
\text { pressure which is } 75 \text { psig. }\end{array}$ & \\
\hline
\end{tabular}

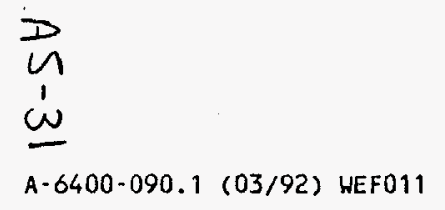




\begin{tabular}{|c|c|c|}
\hline & 1. Date $1 / 20 / 94$ & $\begin{array}{r}\text { Regy.Rdiew No. } \\
101-94-F F T F\end{array}$ \\
\hline REVIEV CUIVIVIEIVI RECUKD (KCK) & $\begin{array}{l}\text { 3. Project No. } \\
\text { FFTF }\end{array}$ & 4. Page \\
\hline
\end{tabular}

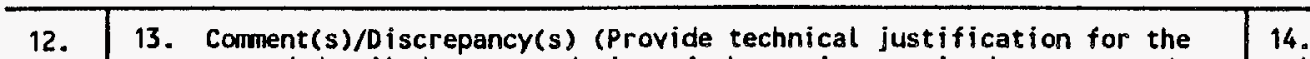

Item comment and detailed recommendation of the action required to correct/ Hold resolve the discrepancy/oroblem indicated.?

5. Section 2.7, Structural Design, is based on Nonreactor Safety $\mathrm{Class} 2$, design criteria. It uses ASME $B$ \& $P V$ code Section III, Subsection NC. However, in Tables 3.4-2 and 3.4-5, the document makes reference to Subsection NB. I think this is conservative detailed calculation methodology adopted in this document, because NB is more severe and stringent than Subsection.NC. Please clarify if different.

6. Pages 12 and 17 , somewhere in the middle of the page, refer to UCRL-15910 Table 4-4 "Recommended Damping Values". The Table 4-4, should be Table 4-6. Please check.

7. The Weight of the Cask has been used $112,0001 \mathrm{~b}$, $120,000 \mathrm{1b}$, and $118,000 \mathrm{1b}$. Fortunately it has been used conservatively in the calculations.

8. In the Natural Phenomena, Floods due to accidental breach of water lines, rain or melting snow are not considered from the point of Criticality etc. Please provide clarify.

Also Tornado is not evaluated in this document, in case the outside casks are picked up and blown away. Whether it is possible or not, please evaluate.

9. Material Properties, Section 3.3.1, does not present the material properties of ASTM A $325, A-82$ or A$185, A-615$ which have been used in the structure of Cask.

Hold
Point

15. Disposition (Provide justification if NOT accepted.)

Subsection NB was used to be conservative, but to be consistent Subsection NC will be referenced.

re

\begin{tabular}{l|l}
16. \\
status
\end{tabular}


WHC-SD-FF-DRR-00018

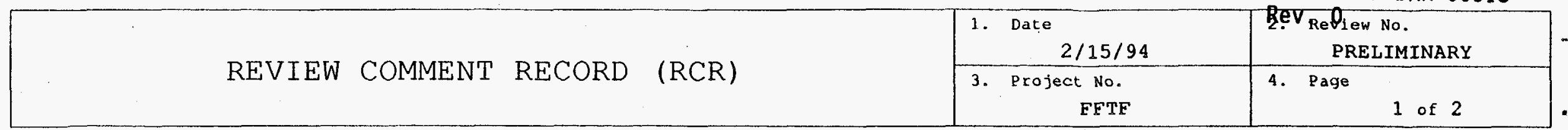

\begin{tabular}{|c|c|c|c|c|}
\hline $\begin{array}{l}\text { 5. Document Number(s)/Title(s) } \\
\text { EFTE SPENT FUEL INTERIM STORAGE CASK } \\
\text { PRELIMINARY DESIGN ANALYSIS REPORT }\end{array}$ & $\begin{array}{l}\text { 6. Program/Project/ } \\
\text { Building Number } \\
\text { FETF }\end{array}$ & $\begin{array}{l}\text { 7. Reviewer } \\
\text { R. L. Simons }\end{array}$ & $\begin{array}{l}\text { 8. Organization/Group } \\
\text { Shielding }\end{array}$ & $\begin{array}{l}\text { 9. Location/Phone } \\
3200 \text { GWW/HO- } \\
35 / 376-8244\end{array}$ \\
\hline 17. Comment Submittal Approval: & 10. Agreement with i & wer/Point of Co & $\begin{array}{l}\text { 11. CLOSED } \\
3-1-94\end{array}$ & ion \\
\hline
\end{tabular}
Ite for the comment and detailed recommendation of the action required $\mathrm{m}$ to correct/ resolve the discrepancy/problem indicated.)

1 The equation 7.10-8 in Schaeffer's text (reference $5.5)$ was developed for neutron scattering through a multi-legged duct. It also will probably work for gamma rays with appropriately chosen parameters; hqwever, this should be demonstrated by comparing it to measured gamma ray data for multi-legged ducts. Schaeffer's text may have the necessary data for this comparisnn.

2 The geometry of the duct allows a direct streaming path to the duct exit as is shown in the attached figure 1. Very little concrete is available for shielding. If a driver fuel assembly is placed adjacent to the duct, rough calculations indicate dose rate at the screen (part 24) location may be as high as $40 \mathrm{rem} / \mathrm{hr}$. The duct dimensions (diameter or length of legs) may be changed to reduce the dose rate This comment is applicable to both the top and bottom ducts.

1

The equation is developed based on albedo theory for both neutrons and gammas. The equations used to derive equation 7.10-8 are independent of particle (neutral particles) type. The particle type (and energy) is taken into account by the albedo $\left(A_{2}\right)$. Shaeffer's text is primarily concerned with neutrons as it is a reactor shielding text. The text however also includes a discussion on gamma scattering through ducts which refers back to the neutron equations but uses the gamma albedo. The albedo used in our analysis we specifically for $1.25 \mathrm{MeV}$ gammas which is what we have in the fuel end fittings. Shaeffer's text also presents experimental results for both neutron and gamma albedo scattering to validate albedo theory.

During final design, we will model the duct and determine the dose rates on the surface of the cask from direct radiation. It the current design provides inadequate shielding, the last leg of the duct will be rotated $90^{\circ}$ so no direct shine is possible. 
WHC-SD-FF-DRR-00018

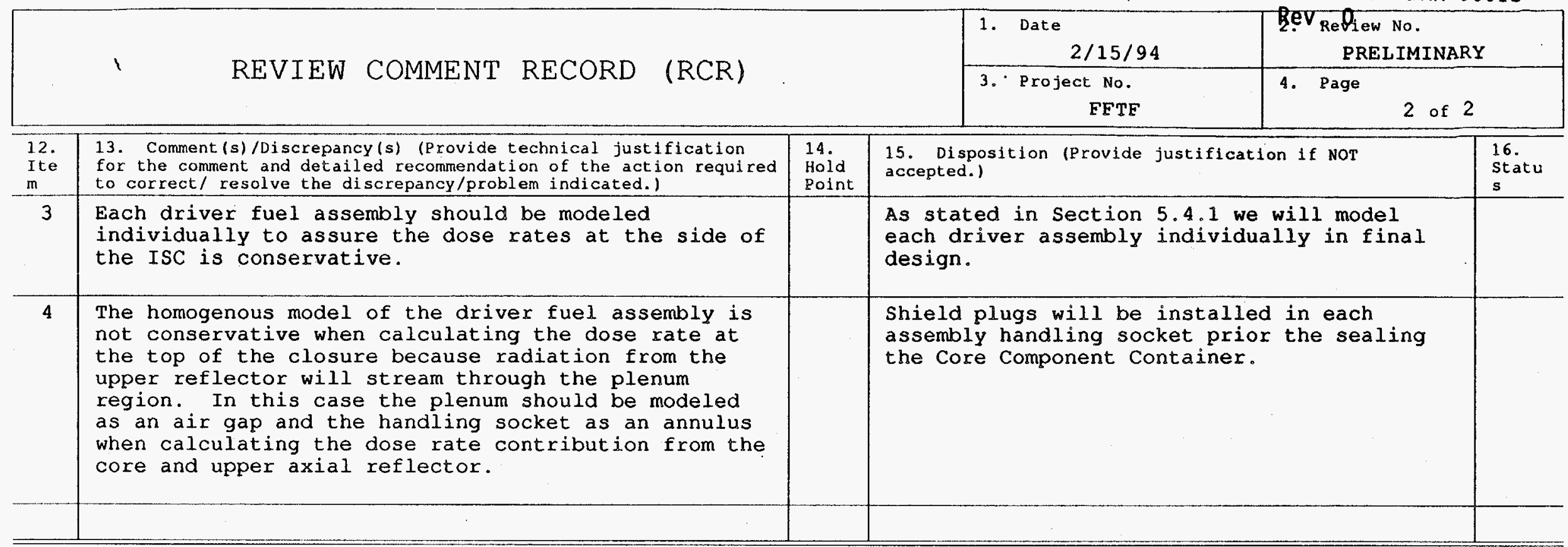


WHC-SD-FF-DRR-00018

\begin{tabular}{|c|c|c|}
\hline \multirow{2}{*}{ REVIEW COMMENT RECORD (RCR) } & $\begin{array}{l}\text { 1. Date } \\
1 / 18 / 94 \\
\end{array}$ & $\begin{array}{l}\text { 2. Review No. } \\
\text { RCR11894 }\end{array}$ \\
\hline & $\begin{array}{l}\text { 3. Project No. } \\
\text { F-027 }\end{array}$ & 4. Page \\
\hline
\end{tabular}

\begin{tabular}{l|l|l|l|l}
\hline 5. Document Number(s)/Title(s) & $\begin{array}{l}\text { 6. Program/Project/ } \\
\text { Building Number } \\
\text { FFTF/F-027 }\end{array}$ & $\begin{array}{l}\text { 7. Reviewer } \\
\text { Paul R. Prevo }\end{array}$ & $\begin{array}{l}\text { South Facilities } \\
\text { Safety Assurance }\end{array}$ \\
\hline
\end{tabular}

9. Location/Phone

10. Agreement with indicated comment disposition(s)

11. CLOSED

17. Comment Submittal Approval:

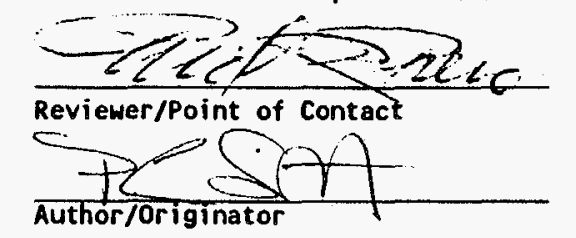

s)ifiy

Date

4702/376-5667

Organization Manager (Optional)
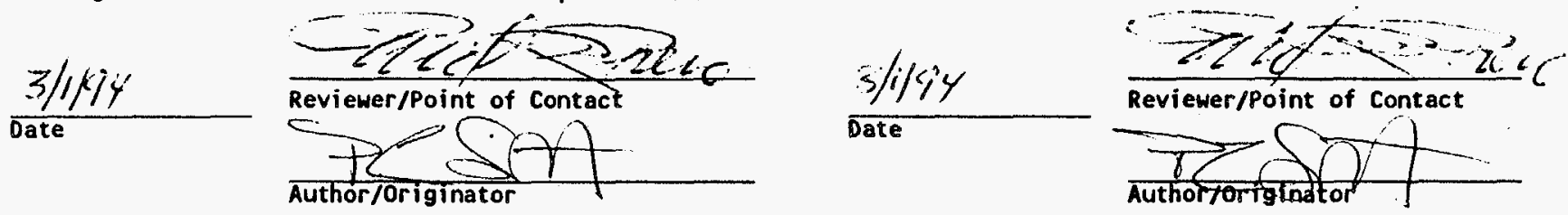

\begin{tabular}{c|l|l|l|l}
\hline $\begin{array}{l}\text { 12. } \\
\text { Item }\end{array}$ & $\begin{array}{l}\text { 13. Comment(s)/Discrepancy(s) (Provide technical justification for the } \\
\text { coment and detailed recommendation of the action required to correct/ } \\
\text { resolve the discrepancy/problem indicated.) }\end{array}$ & $\begin{array}{l}\text { 14. } \\
\text { Hoid } \\
\text { Point }\end{array}$ & 15. Disposition (Provide justification if Nor accepted.). \\
\hline 1 & $\begin{array}{l}\text { Is there quality documentation for the verification } \\
\text { and validation of the two radiation shielding codes } \\
\text { TWODANT AND PATH? }\end{array}$ & PRP & $\begin{array}{l}\text { Yes, GA has submitted the validation reports } \\
\text { status } \\
\text { adequacy. Bob Simons is reviewing them for }\end{array}$ \\
\hline 2 & $\begin{array}{l}\text { As designed the penetration used to leak test and } \\
\text { sample the cavity could permit the uncontrolled } \\
\text { release of particulate contamination. A particulate } \\
\text { filter, such as a sintered metal, would ensure } \\
\text { proper confinement. The filter could be located, } \\
\text { e.g., just beneath the quick disconnect. }\end{array}$ & $\begin{array}{l}\text { Absence of filter plugging could not be } \\
\text { guaranteed for the 50 year life. (This } \\
\text { however, would be a good idea for the } \\
\text { sampling apparatus where the filter could be } \\
\text { replaced if it plugged.) Also, the CCC is } \\
\text { designed to provide the particulate seal. }\end{array}$ \\
$\begin{array}{l}\text { It is now planned that the cask will have a } \\
\text { welded port cover. See discussion below. }\end{array}$
\end{tabular}


WHC-SD-FF-DRR-00018

\begin{tabular}{|l|l|l|}
\hline \multirow{2}{*}{ REVIEW COMMENT RECORD (RCR) } & $\begin{array}{l}\text { i. Date } \\
1 / 18 / 94\end{array}$ & $\begin{array}{c}\text { Rev. Review No. } \\
\text { RCR11894 }\end{array}$ \\
\cline { 2 - 4 } & $\begin{array}{c}\text { 3. Project No. Page } \\
\text { F-027 }\end{array}$ \\
\hline
\end{tabular}

\section{WELDED PORT COVER DISCUSSION}

As agreed in the January 31, 1994, Preliminary Design Review meeting, GA is providing a welded cover over the monitoring port. Attached is a sketch of the design. This design closely parailels the design in the NRC-licensed VSC casks. GA would like to make you aware that the welds are fillet welds and not full penetration welds.

GA believes that this is the best design because it minimizes worker exposure, while meeting the regulations. The NRC has exempted seal welds in closures and port covers from meeting the ASME code requirements because: (1) there are two welds in series for any leak path and this redundancy minimizes any risk to the public and (2) the load on the welds is minimal (pressure is small).

Per the specification, the cask is being designed for a puncture on the top of the cask. The size of the port cover is such that only part of the punch can impact the cover. Most of the punch will be bearing on the rest of the closure. There is always the possibility that, during an angled punch, the punch would hit in such a way as to damage part of the outer cover. Again, the redundancy argument is valid. The primary weld for the inner cover will not be damaged. This hypothetical accident condition comes from a 10CFR71 requirement and is not required per 10CFR72. Double welds are not required in 10CFR71. Therefore, it is GA's opinion that the design does not represent a danger to the public or workers and meets the regulatory requirements and your specification.

Hardcopy being mailed will have the subject figure attached.

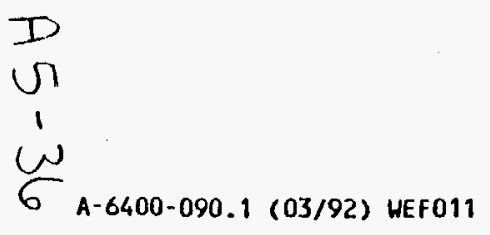




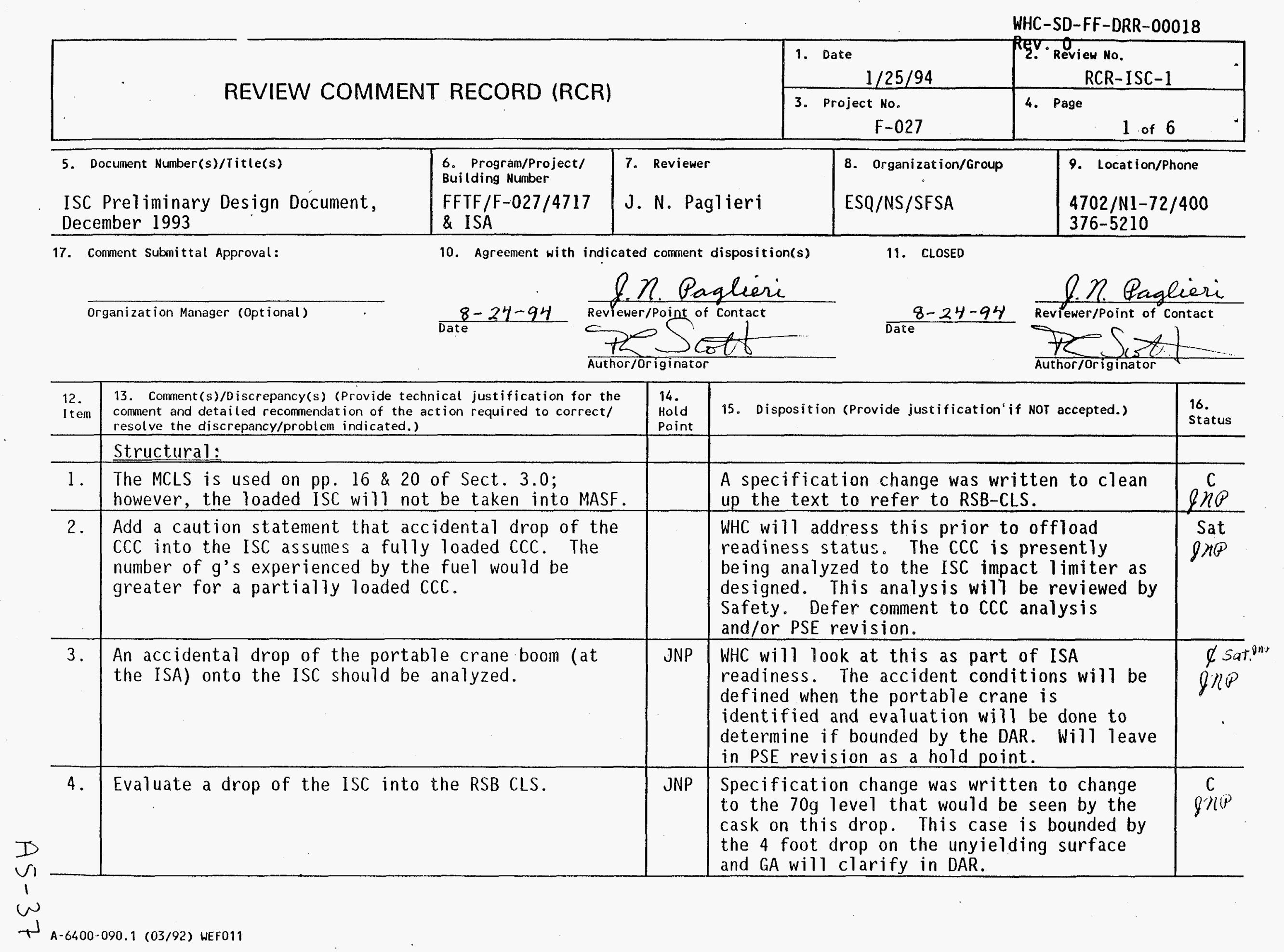


WHC-SD-FF-DRR-00018

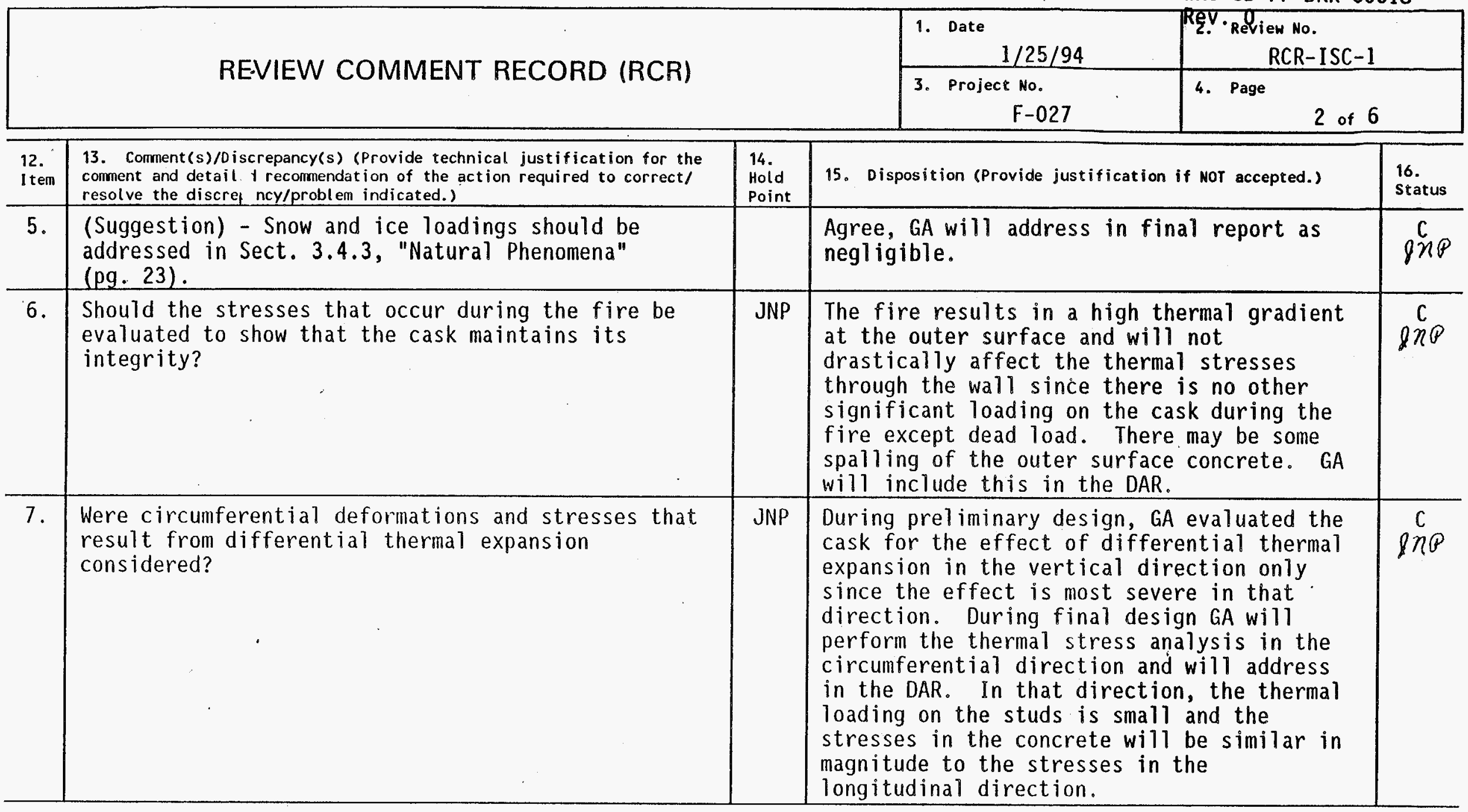


WHC-SD-FF-DRR-00018

\section{REVIEW COMMENT RECORD (RCR)}

$\begin{array}{r}\text { 1. Date } 1 / 25 / 94 \\ \hline 3 .\end{array}$

3. Project No.
Rev Q

$\mathrm{F}-027$ RCR-ISC-1

4. Page

3 of 6

12. 13. Comment( $s$ )/Discrepancy(s) (Provide technical justification for the

Item comment and detailed recommendation of the action required to correct/ resolve the discrepancy/problem indicated.) of thermal loadings together with repeated cycles will cause fatigue failure or extensive accumulations of deformation.

15. Disposition (Provide justification if NOT accepted.)

16.

GA will add a statement in the final design report discussing the expected lack of significant damage on the concrete structure due to thermal cycling, thawing and freezing. Thermal cycling due to daily temperature variations will only affect the outer few inches of the concrete and will not cause any fatigue failure. The temperature variations from winter to summer will only result in a change in the differential temperature between the outside and inside surfaces by approximately

$7^{\circ} \mathrm{F}$ (Delta $\mathrm{T}=470 \mathrm{~F}$ in summer and delta $\mathrm{T}=40$ ${ }^{\circ} \mathrm{F}$ in winter). This change in differential temperature will only change the thermal stresses through the cask wall a small amount. Since there are only one cycle each year, fatigue is not a concern. There will not be any accumulation of deformation due to cycling. The only long term effect is creep which over time will continuously reduce thermal stresses and result in a small amount of axial deformation. Some cracking of the concrete may occur without affecting the structural integrity of the cask. Periodic inspection and maintenance of the cask will be done to monitor cask surface conditions.

9. The adequacy of cooling and temperatures if the ISC report. 


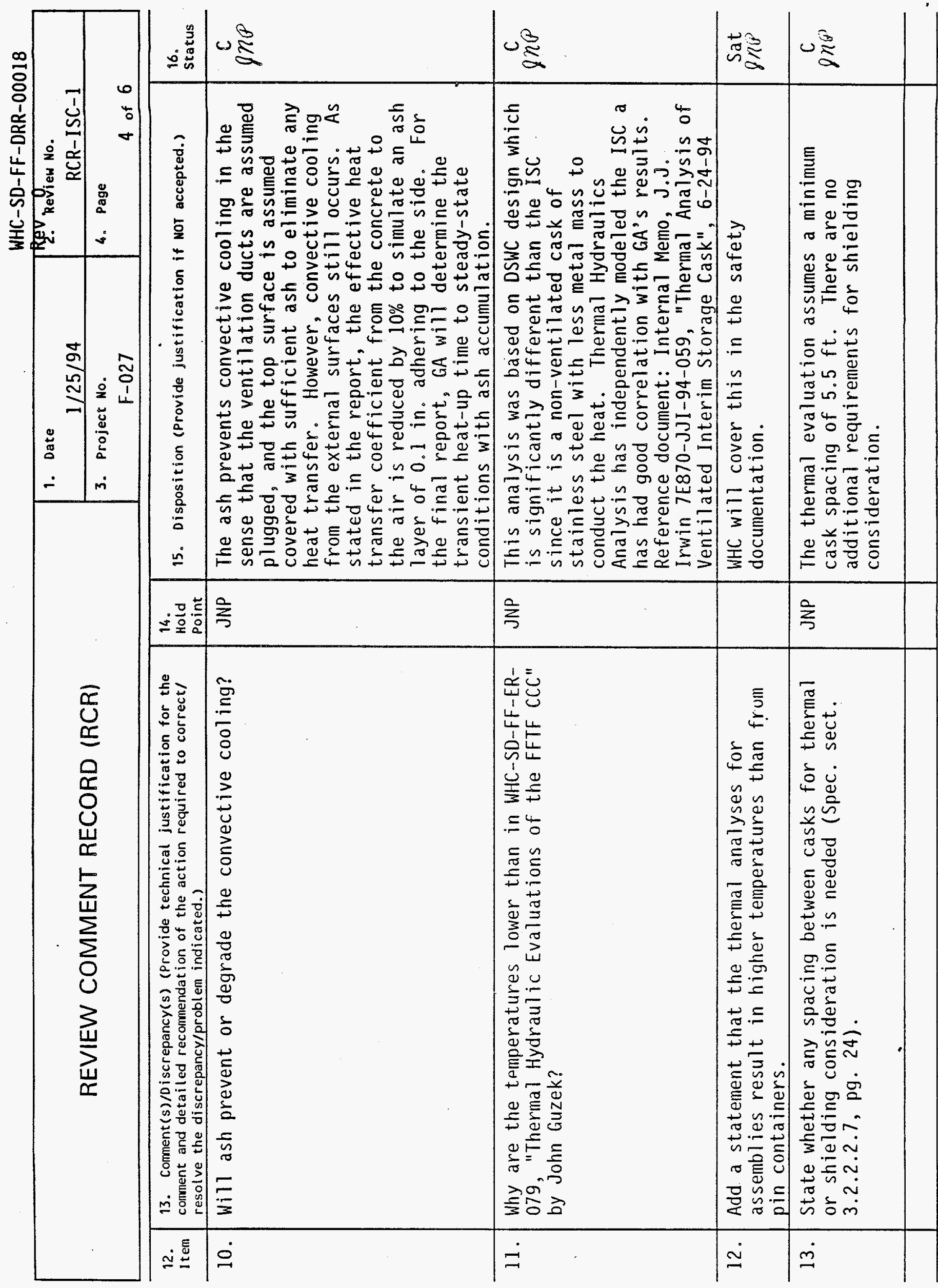


WHC-SD-FF-DRR-00018

\begin{tabular}{|l|l|l|}
\hline \multirow{2}{*}{ REVIEW COMMENT RECORD (RCR) } & $\begin{array}{l}\text { 1. Date } \\
1 / 25 / 94\end{array}$ & $\begin{array}{c}\text { Revi Revi No. } \\
\text { RCR-ISC-1 }\end{array}$ \\
\cline { 2 - 4 } & $\begin{array}{c}3 . \text { Project No. } \\
\text { F-027 Page }\end{array}$ \\
\hline
\end{tabular}

12. 13. Comment( $s$ )/Discrepancy(s) (Provide technical justification for the

Item comment and detailed recomendation of the action required to correct/ : resolve the discrepancy/problem indicated.)

14. Table 5.3-1, "Material Data", should include $\mathrm{Pu}$ in addition to the $U$ in fuel.

15. The loss of water in the concrete over the 50-yr. storage period should be considered in the shielding analysis.

\begin{tabular}{|c|c|c|}
\hline $\begin{array}{l}14 . \\
\text { Hold } \\
\text { Point }\end{array}$ & 15. Disposition (Provide justification if NOT accepted.) & $\begin{array}{l}16 . \\
\text { Status }\end{array}$ \\
\hline & Agree, comment given to $\mathrm{GA}$. & $\stackrel{C}{C}$ \\
\hline JNP & $\begin{array}{l}\text { Loss of water is not expected to be } \\
\text { significant on a massive concrete structure } \\
\text { as the ISC. Any loss will occur in the } \\
\text { outer layer of the concrete and will } \\
\text { fluctuate with the weather. In order to } \\
\text { take into account the loss of water over the } \\
50 \text {-year storage period, we will need time- } \\
\text { dependent neutron and gamma source terms for } \\
\text { the fueled region. It should also be noted } \\
\text { that the neutron contribution to the total } \\
\text { dose rate is minimal. Even a doubling of } \\
\text { the neutron dose rate will not result in a } \\
\text { significant increase int he total dose rate } \\
\text { at the surface of the cask. GA will add } \\
\text { justification tc DAR. }\end{array}$ & $\stackrel{C}{\operatorname{sip}}$ \\
\hline JNP & $\begin{array}{l}\text { The cask used in the shielding calculations } \\
\text { is the } 112,000 \text { ib cask. The total weight of } \\
\text { the shielding model however is much less } \\
\text { than this, since GA used minimum expected } \\
\text { material conditions in their analysis. }\end{array}$ & $\theta \stackrel{c}{n} \rho$ \\
\hline JNP & $\begin{array}{l}\text { WHC changed Specification for consistency on } \\
\text { this requirement. Final design reflects } \\
\text { this. }\end{array}$ & $\begin{array}{c}c \\
g \eta p\end{array}$ \\
\hline & $\begin{array}{l}\text { There are no external impact limiters for } \\
\text { the ISC. }\end{array}$ & grir \\
\hline
\end{tabular}
1

16. State what weight ISC was used for the shielding calculations. Use of a >100,000 weight may be nonconservative.

\section{(}

$\underline{I}_{\mathrm{A}-6400-090.1(03 / 92) \text { WEF } 011}$ 
WHC-SD-FF-DRR-00018

\begin{tabular}{|l|l|l|}
\hline \multirow{2}{*}{ REVIEW COMMENT RECORD (RCR) } & $\begin{array}{l}\text { 1. Date } \\
1 / 25 / 94\end{array}$ & $\begin{array}{l}\text { Rev Review No. } \\
\text { RCR-ISC-1 }\end{array}$ \\
\cline { 2 - 4 } & $\begin{array}{c}3 . \text { Project No. } \\
\text { F-027 Page }\end{array}$ \\
\hline
\end{tabular}

\begin{tabular}{l|l|l|l|l}
\hline $\begin{array}{l}12 . \\
\text { 1tem }\end{array}$ & $\begin{array}{l}\text { 13. Corment(s)/Discrepancy(s) (Provide technical justification for the } \\
\text { coment and detailed recomendation of the action required to correct/ } \\
\text { resolve the discrepancy/problem indicated.) }\end{array}$ & $\begin{array}{l}14 . \\
\text { Hold } \\
\text { Point }\end{array}$ & 15. Disposition (Provide justification if Nor accepted.) \\
\hline 19. & $\begin{array}{l}\text { (Suggestion) - If the computer runs were all put in } \\
\text { appendices at the back, the readability of the } \\
\text { report and the ability to find things would be } \\
\text { significantly improved. }\end{array}$ & $\begin{array}{l}\text { GA has stated that the final report will be } \\
\text { status }\end{array}$ & $\begin{array}{l}\text { C } \\
\text { improved such that readability will be }\end{array}$ \\
\hline
\end{tabular}




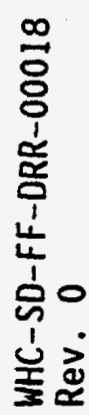

ATTACHMENT 6

FINAL DESIGN REVIEW COMMENT RECORDS

$A 6-1$ 
WHC-SD-FF-DRR-00018

REVIEW COMMENT RECORD (RCR)

\begin{tabular}{rr} 
1. Date \\
$7 / 20 / 94$ \\
\hline 3.
\end{tabular}

3. Project No.

2. Review No. RCR-IS2-2

1 of 3

\section{Document Number(s)/Title(s)}

FFTF Spent Fuel Interim Storage Cask Design Analysis Report by General Atomics, June 1994

17. Comment Submitta! Approval:

6. Program/Project/
Building Number
FFTF/F-027/4717
\&ISA
-

10. Agreement with indicated coment disposition(s)

Organization Manager (Optional)

Reviewer/Point of contact l. R. Paglieri

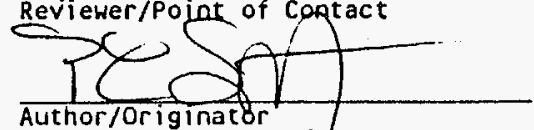

8. Organization/Group

ESQ/TPS/FFFS
9. Location/Phone

$4702 / \mathrm{N} 1-72 / 400$ $376-5210$

\begin{tabular}{|c|c|c|c|c|}
\hline \multicolumn{2}{|c|}{ Organization Manager (Optional) } & & $a-24-04$ & \\
\hline $\begin{array}{l}12 . \\
\text { I ten }\end{array}$ & $\begin{array}{l}\text { 13. Comment(s)/oiscrepancy(s) (Provide technical justification for the } \\
\text { comment and detailed recommendation of the action required to correct/ } \\
\text { resolve the discrepancy/problem indicated.) }\end{array}$ & $\begin{array}{l}14 \\
\text { Hold } \\
\text { Point }\end{array}$ & 15. Disposition (Provide justification if NOT accepted.) & $\begin{array}{l}16 . \\
\text { status }\end{array}$ \\
\hline 1. & $\begin{array}{l}\text { The report refers to MASF and the MASF Cask Loading } \\
\text { Station (MCLS) in a number of places (e.g., pages } \\
2 \times 9-2,6.1-1.6 .2-1,6.3-1 \text { ). Also, sheet } 2 \text { of } \\
\text { drawing } H-4-302134 \text { refers to MASF. Rev. } 3 \text { of the } \\
\text { ISC Spec. (WHC-S-4110) changed the location for } \\
\text { loading the ISC from MASF to the RSB. }\end{array}$ & & $\begin{array}{l}\text { WHC will have GA change all MASF references } \\
\text { to the RSB-CLS including the } 20 \mathrm{ft} \text { drop } \\
\text { condition of } 70 \mathrm{~g} \text {. GA } 1 \mathrm{l}-3 \text { ) }\end{array}$ & $\begin{array}{l}\text { Sat } \\
\ln P\end{array}$ \\
\hline 2. & $\begin{array}{l}\text { Table } 3.4-1, \mathrm{pg}^{3} 3.4-2 \text {. The loading condition "cold } \\
\text { environment: }-27^{\circ} \mathrm{F} \text { ambient temperature" should include } \\
\text { the case of zero decay heat per section } 3.2 .2 .2 .5 . \mathrm{C} \\
\text { (pg. 19) of the ISC Spec. }\end{array}$ & & $\begin{array}{l}\text { GA 3-1) This condition is given in Table } \\
3.4 .1,3^{\text {rd }} \text { Tine. }\end{array}$ & $\stackrel{c}{n} \dot{p}$ \\
\hline 3. & $\begin{array}{l}\text { Section } 4.1 .3, \mathrm{pg} .4 .1-3 \text {. The thermal analysis } \\
\text { should also include hel ium in addition to argon as a } \\
\text { possible inerting gas per sections } 3.2 .2 .1 .9 \text { and } \\
3.2 .2 .2 .2 \text { (pgs. } 17 \& 18 \text { ) of the ISC Spec. }\end{array}$ & JNP & $\begin{array}{l}\text { 4-6) CCC temperatures will be reduced by } \\
\text { helium since its thermal conductivity is } \\
\text { significantly greater than argon. Therefore } \\
\text { the use of argon is conservative. Outside } \\
\text { the CCC envelope, the cask temperatures will } \\
\text { be unaffected by the backfill gas since the } \\
\text { heat generation is fixed at } 1500 \mathrm{~W} \text {. A } \\
\text { statement to this effect will be added to } \\
\text { the DAR. }\end{array}$ & $\stackrel{c}{q \gamma}$ \\
\hline
\end{tabular}

$\frac{1}{6}$

$\grave{\gamma}_{A-6400-090.1}(03 / 92)$ WEF011 


\begin{tabular}{|c|c|c|}
\hline 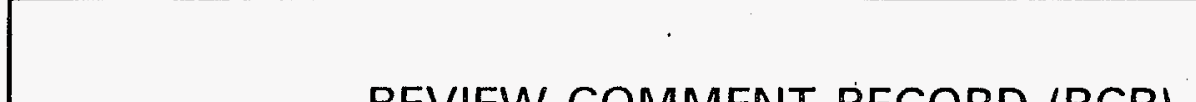 & $\begin{array}{l}\text { 1. Date } \\
7 / 20 / 94 \\
\end{array}$ & $\begin{array}{l}\text { 2. Review No. } \\
\text { RCR-IS2-2 }\end{array}$ \\
\hline 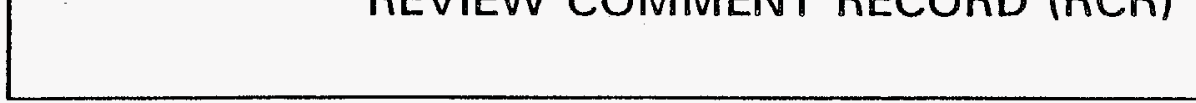 & 3. Project No. & 4. Page \\
\hline
\end{tabular}

\begin{tabular}{|c|c|c|c|c|}
\hline $\begin{array}{l}12 . \\
\text { Item }\end{array}$ & $\begin{array}{l}\text { 13. Comment(s)/Di: :repancy(s) (Provide technical justification for the } \\
\text { conment and detaited recommendation of the action required to correct/ } \\
\text { resolve the discrepancy/problem indicated.) }\end{array}$ & $\begin{array}{l}14 . \\
\text { Hoid } \\
\text { Point }\end{array}$ & 15. Disposition (Provide justification if NOT accepted.) & $\begin{array}{l}16 . \\
\text { Status }\end{array}$ \\
\hline 4. & $\begin{array}{l}\text { Sect. 4.3.2, pg. } 4.3-10 \text {. The thermal analysis } \\
\text { should also address the heavily oxidized paint } \\
\text { condition in accordance with section } 3.2 .2 .2 .9(\mathrm{pg} \text {. } \\
\text { 24) of the ISC Spec. }\end{array}$ & JNP & $\begin{array}{l}\text { GA 4-7) A heavily oxidized surface has a } \\
\text { high emissivity, which is already assumed in } \\
\text { the analysis. The only significant thermal } \\
\text { result that may accompany degradation of the } \\
\text { paint is an increase in the solar } \\
\text { absorptivity. This situation has been } \\
\text { bounded by case } 6 \text { (ash with plugged ducts) } \\
\text { in which the absorptivity was increased to } \\
0.8 \text {. A statement to this effect will be } \\
\text { added to the DAR. Note that the section on } \\
\text { maintenance recommends repainting if the } \\
\text { paint is chipped, spalled, discolored, or } \\
\text { has other surface defects. }\end{array}$ & $\stackrel{c}{\sin p}$ \\
\hline 5. & $\begin{array}{l}\text { Sect. } 5.3 .2, \mathrm{pg} .5 .3-6 \text {. The last sentence of Sect. } \\
5.3 .2 \text { should be revised to read: "The neutron source } \\
\text { term decays with age, in addition, even doubling the } \\
\text { neutron dose rate does not significantly increase } \\
\text { the total surface dose rates on the ISC." }\end{array}$ & & $\begin{array}{l}\text { GA } 5-2) \text { Sentence revised to read as } \\
\text { requested. }\end{array}$ & $\stackrel{c}{\ln \theta}$ \\
\hline 6. & $\begin{array}{l}\text { Sect. } 5.4 .3, \mathrm{pg} .5 .4-2 \text {. The standard ANSI/ANS } \\
6.1 .1-1977 \text { that was used for the flux-to-dose } \\
\text { conversion factors has been replaced by ANSI/ANS } \\
6.1 .1-1991 \text { according to the Hanford Kaiser Library. }\end{array}$ & JNP & $\begin{array}{l}\text { GA 5-3) GA used ANSI/ANS } 6.1 .1-1977 \text { as the } \\
\text { NRC has not yet accepted ANSI/ANS } 6.1 .1- \\
1991 \text {. In addition, based on a review of the } \\
\text { two standards, it is conservative to use } \\
\text { ANSI/ANS } 6.1 .1-1977 \text { as ANSI/ANS } 6.1 .1-1991 \\
\text { would effect lower dose rates for the ISC } \\
\text { cask. }\end{array}$ & $\stackrel{c}{\ln p}$ \\
\hline
\end{tabular}


WHC-SD-FF-DRR-00018

\begin{tabular}{|c|c|c|c|c|c|}
\hline \multirow{2}{*}{\multicolumn{3}{|c|}{ REVIEW COMMENT RECORD (RCR) }} & \multirow{2}{*}{\begin{tabular}{|l|l|} 
& $7 / 20 / 94$ \\
\cline { 2 - 2 } & 3. Project No.
\end{tabular}} & \multicolumn{2}{|c|}{$\begin{array}{l}\text { Rev. Review No. } \\
\text { RCR-IS2-2 }\end{array}$} \\
\hline & & & & \multicolumn{2}{|l|}{ 4. Page } \\
\hline $\begin{array}{l}12 . \\
\text { item }\end{array}$ & $\begin{array}{l}\text { 13. Comment( }(s) / D \text { iscrepancy(s) (Provide technical justification for the } \\
\text { comment and detailed recommendation of the action required to correct/ } \\
\text { resolve the discrepancy/problem indicated.) }\end{array}$ & $\begin{array}{l}14 . \\
\text { Hold } \\
\text { Point }\end{array}$ & \multicolumn{2}{|c|}{ 15. Disposition (Provide justification if NOT accepted.) } & $\begin{array}{l}16 . \\
\text { status }\end{array}$ \\
\hline 7. & $\begin{array}{l}\text { Sect. } 6.1 \text {, pg. } 0.1-1 . \text { The maximum height and } \\
\text { diameter of the ISC to assure interface } \\
\text { compatibility with the RSB and RSB-CLS structure } \\
\text { should be stated in the text (maximum of } 182^{\prime \prime} \text { ht. by } \\
92^{\prime \prime} \text { diameter per pg. } 40 \text { of the ISC Spec.). }\end{array}$ & & \multicolumn{2}{|c|}{$\begin{array}{l}\text { GA } 6-1) \text { The following sentence will be } \\
\text { added to Section } 6.1 \text { : } \\
\text { The ISC is } 84.64 \text { in. diameter } x 180.41 \text { in. } \\
\text { tall without the cover plate, which meets } \\
\text { the limits defined in WHC-S-4110, Sections } \\
3.2 .2 .1 .6 \text { and } 3.2 .4 .1 \text {. }\end{array}$} & $\begin{array}{l}\text { Sat. } \\
\operatorname{gn\rho }\end{array}$ \\
\hline 8. & $\begin{array}{l}\text { Sect. } 6.2 .1, \mathrm{pg} .6 .2-1 \text { The text refers to the MASF } \\
200-\text { ton crane, } 75 \text {-ton Hydraset, and } 85-\text { ton shackle. } \\
\text { According to pgs. } 14,40 \text {, and } 41 \text { of the ISC Spec, } \\
\text { the RSB handling equipment consists of the } 100 \text {-ton } \\
\text { RSB crane, } 75 \text {-ton (or 150-ton) Hydraset, and } 100 \text {-ton } \\
\text { shackle. }\end{array}$ & JNP & \multicolumn{2}{|c|}{$\begin{array}{l}\text { GA 6-2) Will revise Sect } 6.2 .1 \text { to refer to } \\
\text { correct capacities. }\end{array}$} & $\begin{array}{l}\text { Sat. } \\
\ln \beta\end{array}$ \\
\hline 9. & $\begin{array}{l}\text { Sect. } 6.2 .2, \mathrm{pg} .6 .2-1 \text {. A statement should be added } \\
\text { that the weight of the ISC with a } 5000 \mathrm{lb} \text { payload } \\
\text { plus the tiedown equipment does not exceed the } \\
\text { transporter payload limit of } 120,000 \mathrm{lbs} \text { (pg. } 17 \text { of } \\
\text { the ISC Spec.). }\end{array}$ & & \multicolumn{2}{|c|}{ GA 6-3) Will revise write-up. } & $\begin{array}{l}\text { Sat. } \\
\text { gne }\end{array}$ \\
\hline & & & & & \\
\hline
\end{tabular}

$\frac{7}{6}$ 
WHC-SD-FF-DRR-00018

\begin{tabular}{|c|c|c|}
\hline & $\begin{array}{r}\text { 8. Date } \\
7 / 19 / 94 \\
\end{array}$ & $\begin{aligned} \text { 2. Review No. } \\
071994\end{aligned}$ \\
\hline REVIEW COMIMEN I RECOHD (RCR) & $\begin{array}{l}\text { 3. Project No. } \\
\text { ISC }\end{array}$ & 4. Page \\
\hline
\end{tabular}

5. Document Number(s)/Title(s)

ISC Design Analysis Report
6. Program/Project/ Building Number FFTF/ISC

7. Reviewer
P. R. Prevo

i0. Agreement with indicated comment disposition(s)

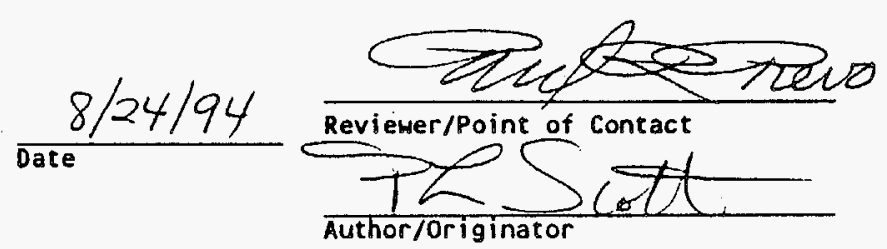

\begin{tabular}{l|l} 
8. Organization/Group & 9. Location/Phone. \\
FFTF and Fuel & Nl-72/376-5667 \\
Facility Safety &
\end{tabular}

11. CLOSED
17. Comment Submittal Approval:

Organization Manager (Optional) Author/originator

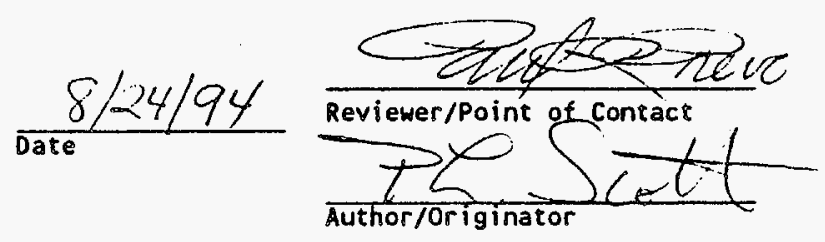

\begin{tabular}{|c|c|c|c|c|}
\hline $\begin{array}{l}12 . \\
\text { Item }\end{array}$ & $\begin{array}{l}\text { 13. Comment(s)/Discrepancy(s) (Provide technical justification for the } \\
\text { corment and detailed recommendation of the action required to correct/ } \\
\text { resolve the discrepancy/problem indicated.) }\end{array}$ & $\begin{array}{l}\text { Ma. } \\
\text { Hold } \\
\text { Point }\end{array}$ & 15. Disposition (Provide justification if NOT accepted.) & $\begin{array}{l}16 . \\
\text { Status }\end{array}$ \\
\hline 1 & $\begin{array}{l}\text { What are the transient radiation levels near the top } \\
\text { of the cask a: the loaded CCC is lowered into the } \\
\text { ISC at the Cask Loading Station? Especially } \\
\text { interested in potential streaming due to the } \\
\text { shielding void created by the ventilation duct at } \\
\text { the top of the cask. }\end{array}$ & PRP & $\begin{array}{l}\text { WHC will evaluate this under normally } \\
\text { unaccessable area transient dose rate } \\
\text { criteria, if required. }\end{array}$ & \\
\hline 2 & $\begin{array}{l}\text { 7-2) Shielding tests - Does this method verify the } \\
\text { dose rate at the vents? }\end{array}$ & & $\begin{array}{l}\text { This method does not verify the dose rate at } \\
\text { the vents because a standard cannot be built } \\
\text { with which to compare the gamma scan } \\
\text { results. There is no gamma scan methodology } \\
\text { which can be used to verify the dose rate at } \\
\text { the vents. The only way to test the vents } \\
\text { is to actually load the fuel into the ISC } \\
\text { and take dose rate measurements around the } \\
\text { vents. }\end{array}$ & \\
\hline
\end{tabular}


WHC-SD-FF-DRR-00018

\begin{tabular}{|l|l|l|}
\hline \multirow{2}{*}{ REVIEW COMMENT RECORD (RCR) } & 1. Date & $\begin{array}{c}\text { Rev Review No. } \\
071994\end{array}$ \\
\cline { 2 - 4 } & 3. Project No. & 4. Page \\
\hline
\end{tabular}

12. 13. Corment(s)/Discrepancy(s) (Provide technical justification for the corment and detailed recommendation of the action required to correct/

There are two concerns with the PATH correction

14. Point factor calculation presented in Section 5.0. First, a ratio of calculated to measured radiation levels for the VSC-24 and MTC casks is reported as 3.1. What assurance do we have that the actual radiation source that was present in the casks during the measurements was actually the maximum as was probably assumed in the calculations? It seems credible that the actual radiation source was much less than assumed in the shielding code calculations. For example, the radiation source specified for the FFTF ISC is larger than most if not all of the actual fuel assemblies. If radiation level measurements were made after fuel assemblies were loaded into the cask, the ratio of calculated to measured radiation levels would probably be substantially greater than one. However, this would not necessarily mean that the shielding code was conservative since other factors, such as, conservatism in the source could also explain the difference. second, what assurance do we have that the radiation energy spectrum of the source is the same or similar between the VSC-24, the MTC and the ISC?

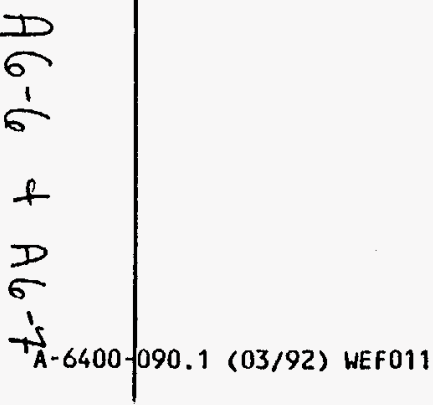

15. Disposition (Provide justification if NOT accepted.)

GA 5.1)- The PATH correction factor calculation presented in Section 5.0 is for the actual fuel loaded in the vSC-24 at the Pal isades Nuclear Station (Ref. 5.6 of Design Analysis Report). The fuel source terns used in the analysis are for $33 \mathrm{GWd} / \mathrm{MTU}$ burnup and 10 year cooled fuel, which represents the average burnup and cooling time of the fuel loaded in the the average burnup and cooling time of the fuel loaded in the
cask. The burnup calculations performed by the reactor owners cask. The burnup calculations performed by the reactor
are used to predict start-up reactivity and the startup reactivity must be within $q\{x$ in keff. This gives high confidence that the burnup predictions are accurate. EPRI/DOE have also measured assembly burnups using the FORK measurement system at the Oconee Nuclear Station of the Duke Power Company (Ewing, R. 1.. "Burnup Verification Using the Fork Measurement System, "High Level Radioactive Waste Management Proceedings vol. 2, 1994). The results of the measurements show that the assembly burnup from the plant records are within $\pm 2.2 \%$ of the measured values. Therefore it may be concluded that the source used to determine the correction factor is consistent with the source in the measured cask. Pages 5.5-17 and 18 of the Design Analysis Report explain hou the correction factor the Design Analysis Report explain how the correction factor factor of 2 used for the ISC and the factor of 3.1 found with factor of 2 used for the USC-24 cask is due to the difference in relative concrete and steel thicknesses in the two cask relative concrete and steel thicknesses in the two cask
designs. The figure (see 5.1) shows that the gamma spectra designs. The figure (see $5-1$ ) shows that the gama spectra
for the two fuel types are very similar. The fFTf spectrum is somewhat harder. However, this will have little effect on the ratio of measured to calculated dose rates because the gamma absorption and scattering cross sections and the flux to dose rate conversion factors are very well behaved.

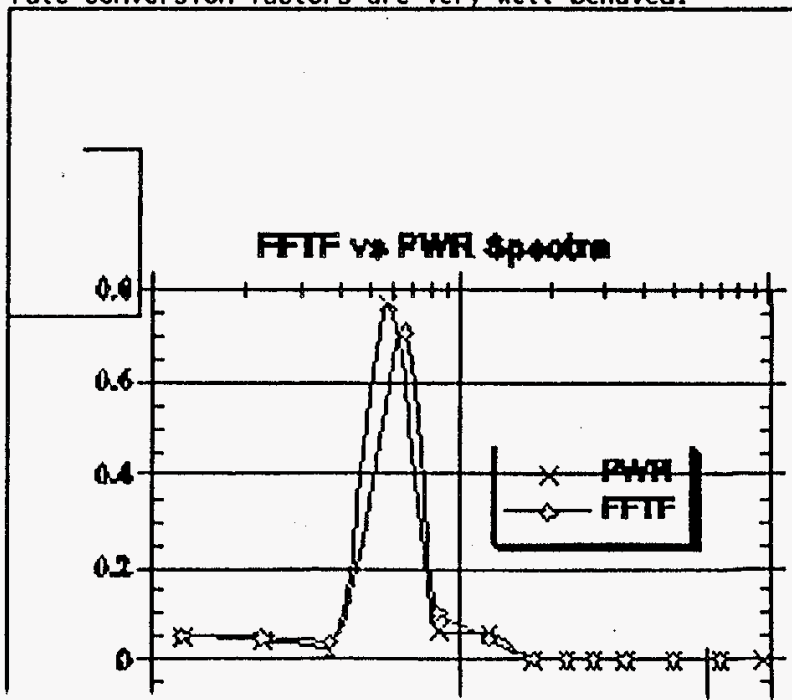

16. Status $\operatorname{tin} \varepsilon$

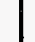

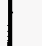


WHC-SD-FF-DRR-00018

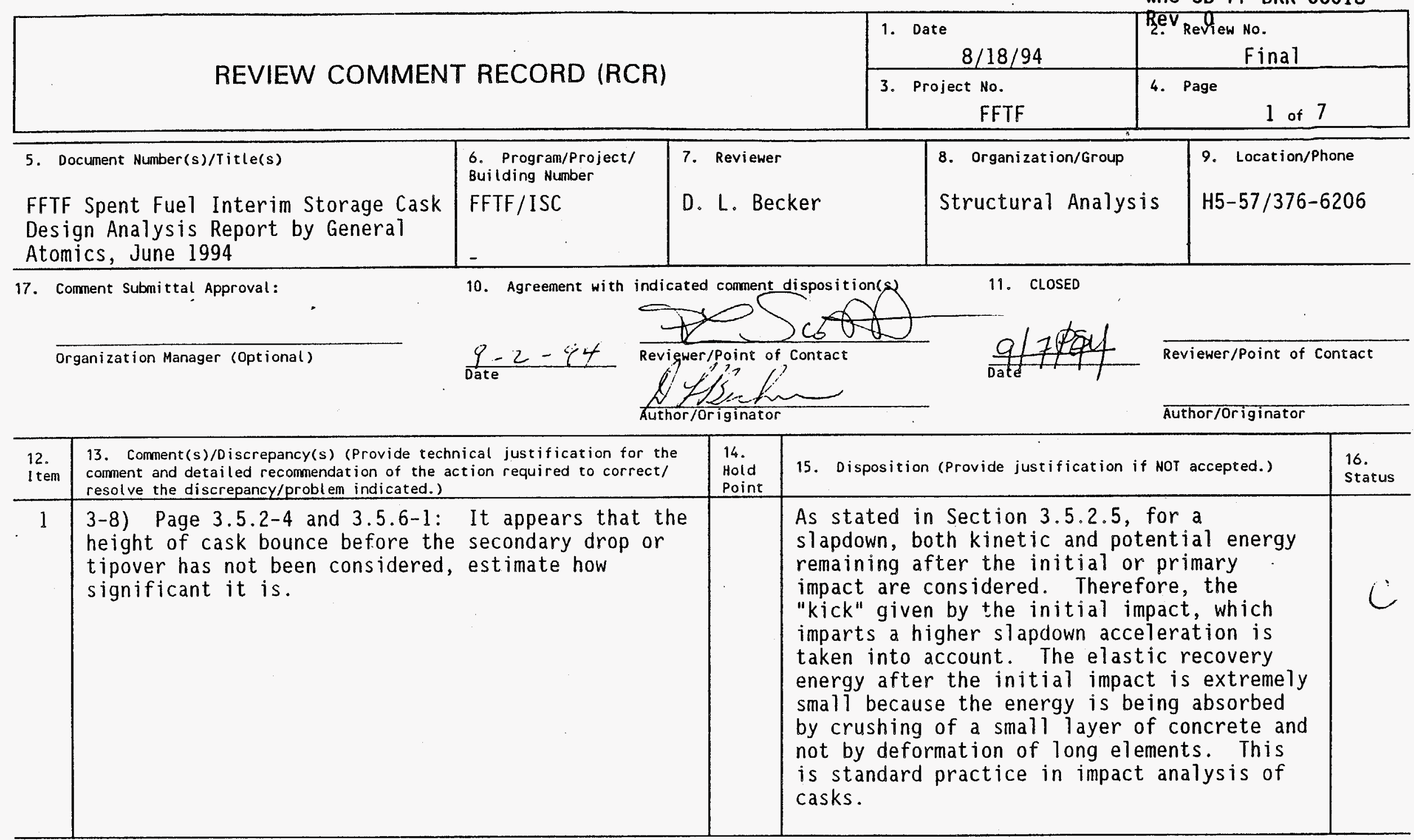




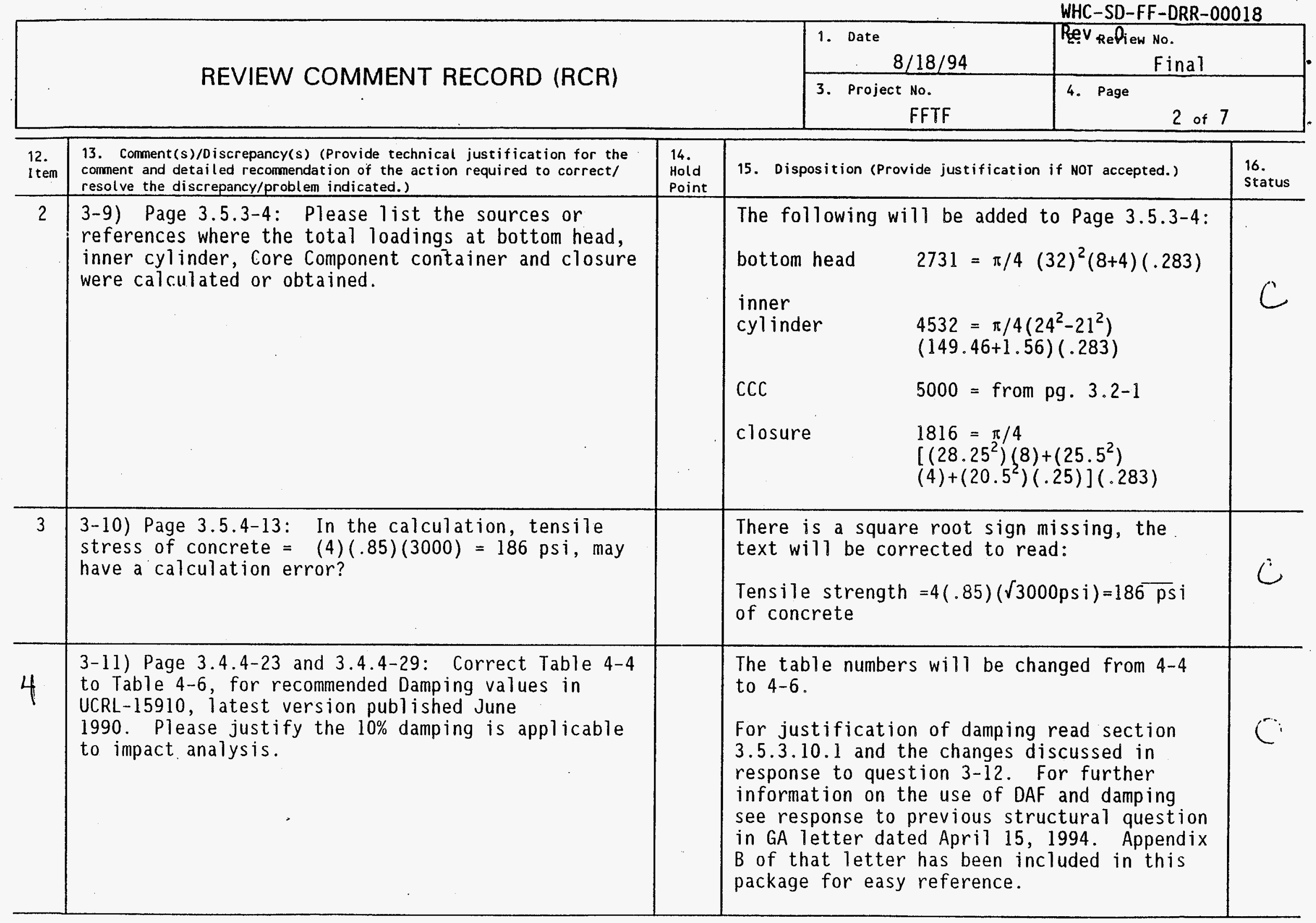




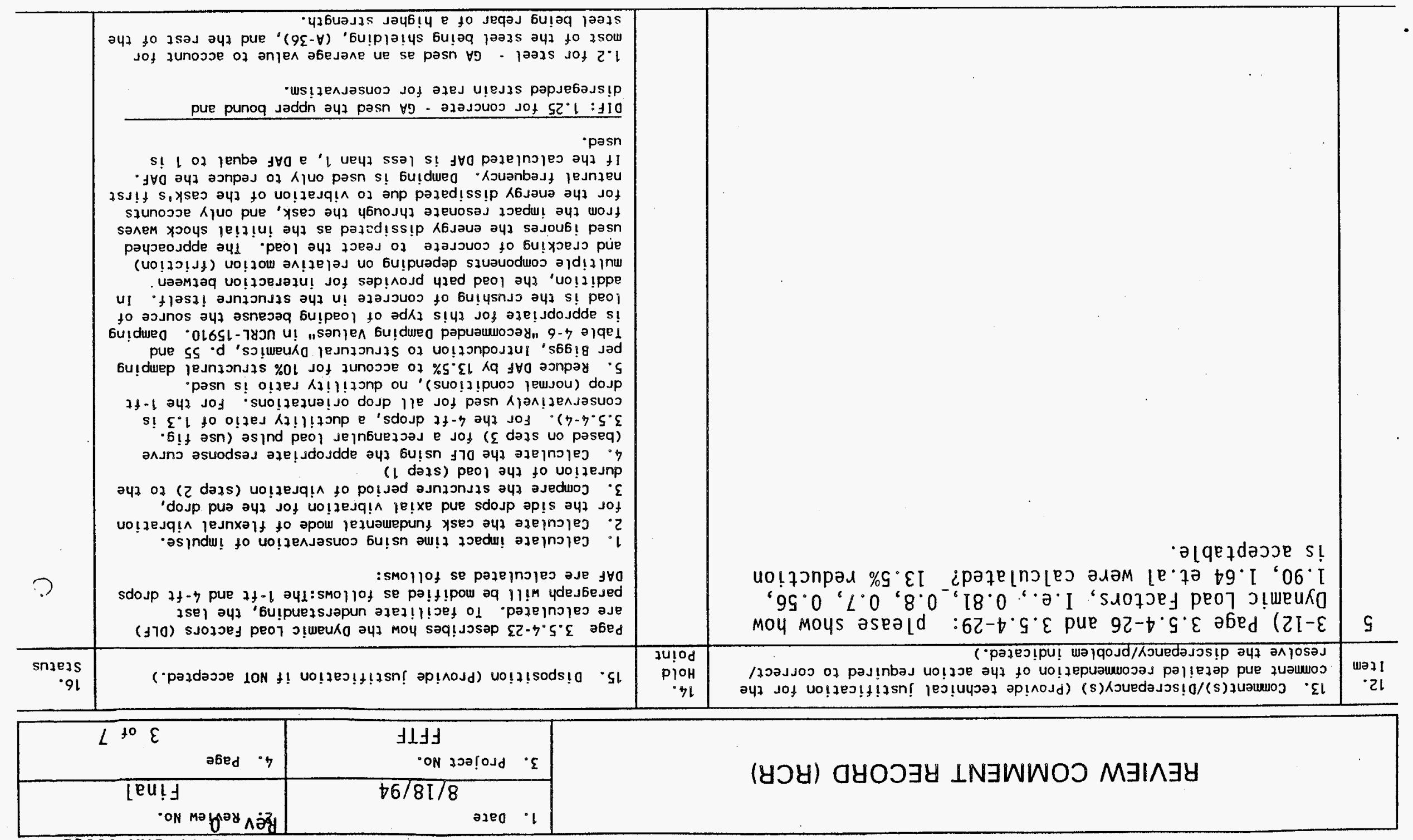




\section{REVIEW COMMENT RECORD (RCR)}

\begin{tabular}{|c|l|}
\hline $\begin{array}{c}\text { 1. Date } \\
8 / 18 / 94\end{array}$ & \multicolumn{2}{|l|}{$\begin{array}{c}\text { Rev } \\
\text { FeV }\end{array}$} \\
\hline $\begin{array}{c}\text { 3. Project No. } \\
\text { FFTF }\end{array}$ & 4. Page \\
\hline
\end{tabular}

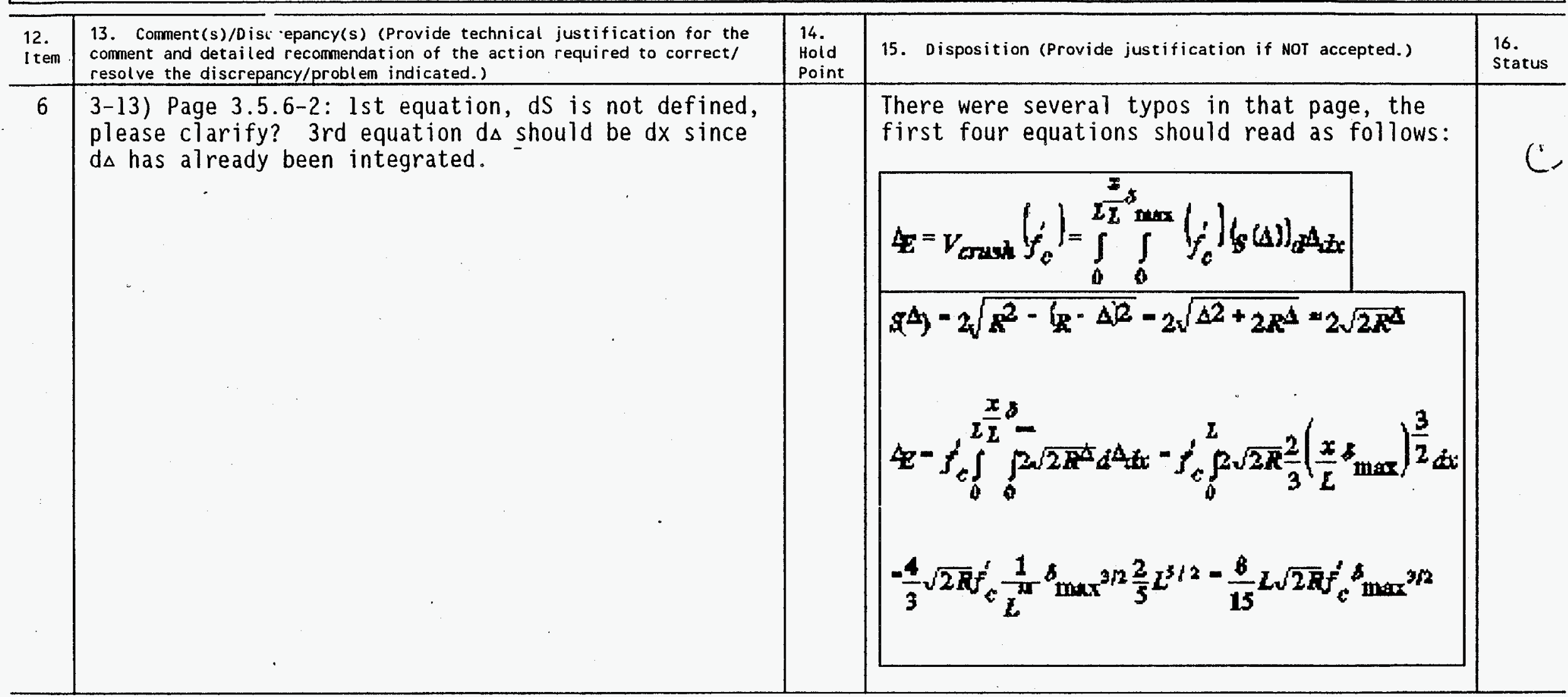




\begin{tabular}{|c|c|c|}
\hline & $\begin{array}{r}\text { 1. Date } \\
8 / 18 / 94 \\
\end{array}$ & $\begin{array}{r}\text { Rẹv }_{\text {Revlew No. }} \\
\text { Final }\end{array}$ \\
\hline 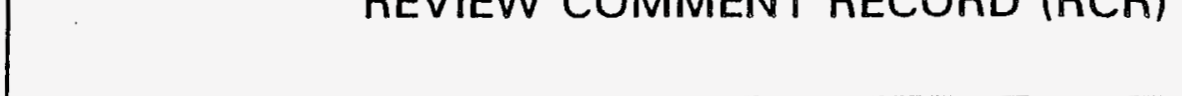 & $\begin{array}{l}\text { 3. Project No. } \\
\text { FFTF }\end{array}$ & 4. Page \\
\hline
\end{tabular}

\begin{tabular}{|c|c|c|c|c|}
\hline $\begin{array}{l}12 . \\
\text { item }\end{array}$ & $\begin{array}{l}\text { 13. Comment(s)/Discrepancy(s) (Provide technical justification for the } \\
\text { comment and detailed recommendation of the action required to correct/ } \\
\text { resolve the discrepancy/problem indicated.) }\end{array}$ & $\begin{array}{l}14 . \\
\text { Hold } \\
\text { Point }\end{array}$ & 15. Disposition (Provide justification if NOT accepted.) & $\begin{array}{l}16 . \\
\text { Status }\end{array}$ \\
\hline 7 & $\begin{array}{l}\text { 3-14) Appendix } C \text { (Computer Code SAC outputs) It } \\
\text { appears that the ring section has sustained a fairly } \\
\text { high stress, i.e. page } C 049,11,848 \text { psi is this } \\
\text { concrete stress or steel stress? Or if this stress } \\
\text { is for steel, ow about buckling effects on thin } \\
\text { shell or at discontinuity section? }\end{array}$ & & $\begin{array}{l}\text { As described in Section } 3.5 .3 \text {, the SAC } \\
\text { analysis was used to analyze the all-steel } \\
\text { confinement boundary. The analysis } \\
\text { represents a bottom end drop. During this } \\
\text { event, the confinement boundary liner } \\
\text { experiences a tensile stress due to the CCC } \\
\text { and bottom plate weight. Page C048 shows } \\
\text { that a tensile membrane stress of } 21.05 \mathrm{ksi} \\
\text { (See also Page } 3.5 .3-10 \text { ) is produced in the } \\
\text { liner wall, even at the discontinuity, } \\
\text { therefore, buckling is not a concern. The } \\
\text { compressive stress on the ring is due to } \\
\text { bending stress as described in page } 3.5 .3- \\
\text { lo, this type of loading is not of concern } \\
\text { from the standpoint of buckling of the thick } \\
\text { ring. }\end{array}$ & \\
\hline 8 & $\begin{array}{l}\text { 3-15) WHC is pleased with the comparison approach } \\
\text { of GACAP to DYNA3D. However, WHC is not yet } \\
\text { satisfied with the data provided for verification of } \\
\text { the GACAP code. WHC would like to see a comparison } \\
\text { between GACAP and DYNA3D for a concrete structure } \\
\text { which responds differently from steel structures } \\
\text { under impact loading. It is believed that a } \\
\text { concrete element behaves quite differentiy from a } \\
\text { general purpose element. }\end{array}$ & & $\begin{array}{l}\text { Additional verification work is out of the } \\
\text { scope of this contract, and can be performed } \\
\text { at additional cost. For a better } \\
\text { understanding of the usage of the codes in } \\
\text { the ISC analyzes please review GA responses } \\
\text { to WHC structural comments in the letters } \\
\text { dated: February } 24 \text {, April } 5 \text {, and June } 20 \text {, } \\
\text { 1994. } \\
\text { GA used GACAP to predict the loads and } \\
\text { forces acting on the concrete structure. } \\
\text { The behavior of the concrete reacting to } \\
\text { these loads is calculated by hand per ACI- } \\
349 \text { criteria. There is no reason to } \\
\text { validate a concrete finite element. }\end{array}$ & \\
\hline
\end{tabular}


WHC-SD-FF-DRR-00018

\begin{tabular}{|c|c|c|}
\hline & $\begin{aligned} & 1 . \text { Date } \\
& 8 / 18 / 94 \\
&\end{aligned}$ & $\begin{array}{r}\text { ReV RevPew No. } \\
\text { Final }\end{array}$ \\
\hline REVIEW CUMIMEN I RELURD (RCK) & $\begin{array}{l}\text { 3. Project No. } \\
\text { FFTF }\end{array}$ & $\begin{array}{l}\text { 4. Page } \\
6 \text { of } 7 \\
\end{array}$ \\
\hline
\end{tabular}

\begin{tabular}{|c|c|c|c|c|}
\hline $\begin{array}{l}12 . \\
\text { I tem }\end{array}$ & $\begin{array}{l}\text { 13. Comment(s)/Discrepancy(s) (Provide technical justification for the } \\
\text { comment and detailed recommendation of the action required to correct/ } \\
\text { resolve the discrepancy/problem indicated.) }\end{array}$ & $\begin{array}{l}14 . \\
\text { Hold } \\
\text { Point }\end{array}$ & 15. Disposition (Provide justification if NOT accepted.) & $\begin{array}{l}16 . \\
\text { status }\end{array}$ \\
\hline 9 & $\begin{array}{l}\text { 3-16) WHC would like to see that ILMOD be verified } \\
\text { against a concrete element of either one of the } \\
\text { following codes: ANSYS, ABAQUS, or DYNA3D. Please } \\
\text { also provide us with the theoretical backgrounds and } \\
\text { approaches used in the ILMOD code. }\end{array}$ & & $\begin{array}{l}\text { ILMOD is a geometry based code. It } \\
\text { calculates areas and multiplies the areas by } \\
\text { a user supplied stress. It cannot be } \\
\text { compared to the above codes. }\end{array}$ & \\
\hline 10 & $\begin{array}{l}\text { 3-17) Please have the SAC code verified against } \\
\text { either one of the following codes: ANSYS or ABACUS. } \\
\text { Show applicability to asymmetrical loading } \\
\text { conditions and discontinuities. }\end{array}$ & & $\begin{array}{l}\text { SAC is an axisymmetric code used to analyze } \\
\text { only axisymmetric loads during the end drop. } \\
\text { There are no asymmetrical loads for this } \\
\text { drop orientation. The SAC code validation } \\
\text { was provided in } 2 / 11 / 94 \text {. GA sees no need or } \\
\text { value in further verification. }\end{array}$ & \\
\hline
\end{tabular}




\begin{tabular}{|l} 
1. \\
8 Date \\
$8 / 18 / 94$
\end{tabular}

FFTF
15. Disposition (Provide justification if Nor accepted.) Point

12. 13. Comment( $s$ )/Discrepancy(s) (Provide technical justification for the item coment and detailed recommendation of the action required to correct/ resolve the discrepancy/problem indicated.)

11 4-8) Page 4.1-3, Section 4.1.3, The discussion of how concrete temperatures meet $A C I-349$ for the various conditions.

For long-term limit condition: Need to define the extent of the local temperatures above $150^{\circ} \mathrm{F}$ in the text, describe specifically what area is affected. ACI-349 does not refer to bulk or average concrete temperature requirements. Clearly define how these are calculated. In earlier correspondence GA provided background information that justified that the concrete does not lose strength below $200^{\circ} \mathrm{F}$.

This information needs to be included in these discussions to back-up the acceptability of localized temperatures above $200^{\circ} \mathrm{F}$.

For off-normal condition: Need to define the extent of the local temperatures above $150^{\circ} \mathrm{F}$.

For the Plugged duct discussion: Need to define the extent of the ocal temperatures above $150^{\circ} \mathrm{F}$. It is questionable whether this can still be considered local but emphasis could be placed on the

justification mentioned above. Also, the case needs to be built that justifies not recommending duct outlet temperature monitoring. Since, per the justification, the concrete does not lose strength at temperatures less than $200^{\circ} \mathrm{F}$ this case could possibly be made based on this accident condition.
As shown in the isotherm plot of Fig. 4.3-6, for long-term normal conditions only a very small portion of the concrete, in the top corner area between the inner and outer shields, is above $150^{\circ} \mathrm{F}$.

Several volume-averaged concrete temperatures are computed, as shown in Table 4.3-2. The "outer shield" average is taken over the length of the outer shield; the "shield" average is over the length of the inner and outer shields; and the "overall" average is over the entire volume of concrete.

Figure 4.3-7 shows the extent of the concrete above $150^{\circ} \mathrm{F}$ for off-normal severe conditions.

Figure 4.3-13 shows the extent of the concrete above $150^{\circ} \mathrm{F}$ for the plugged duct condition.

Appendix 0 will be included to provide information showing that the concrete retains strength at temperatures below $200^{\circ} \mathrm{F}$. For all cases except the fire accident the concrete (overall) average temperature is $\leq 139^{\circ} \mathrm{F}$ and the maximum local temperature is $\leq 177^{\circ} \mathrm{F}$. Outlet duct temperature monitoring is therefore not required.

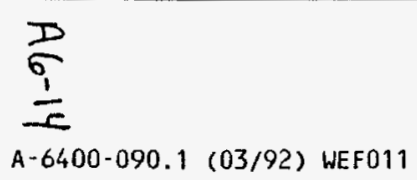




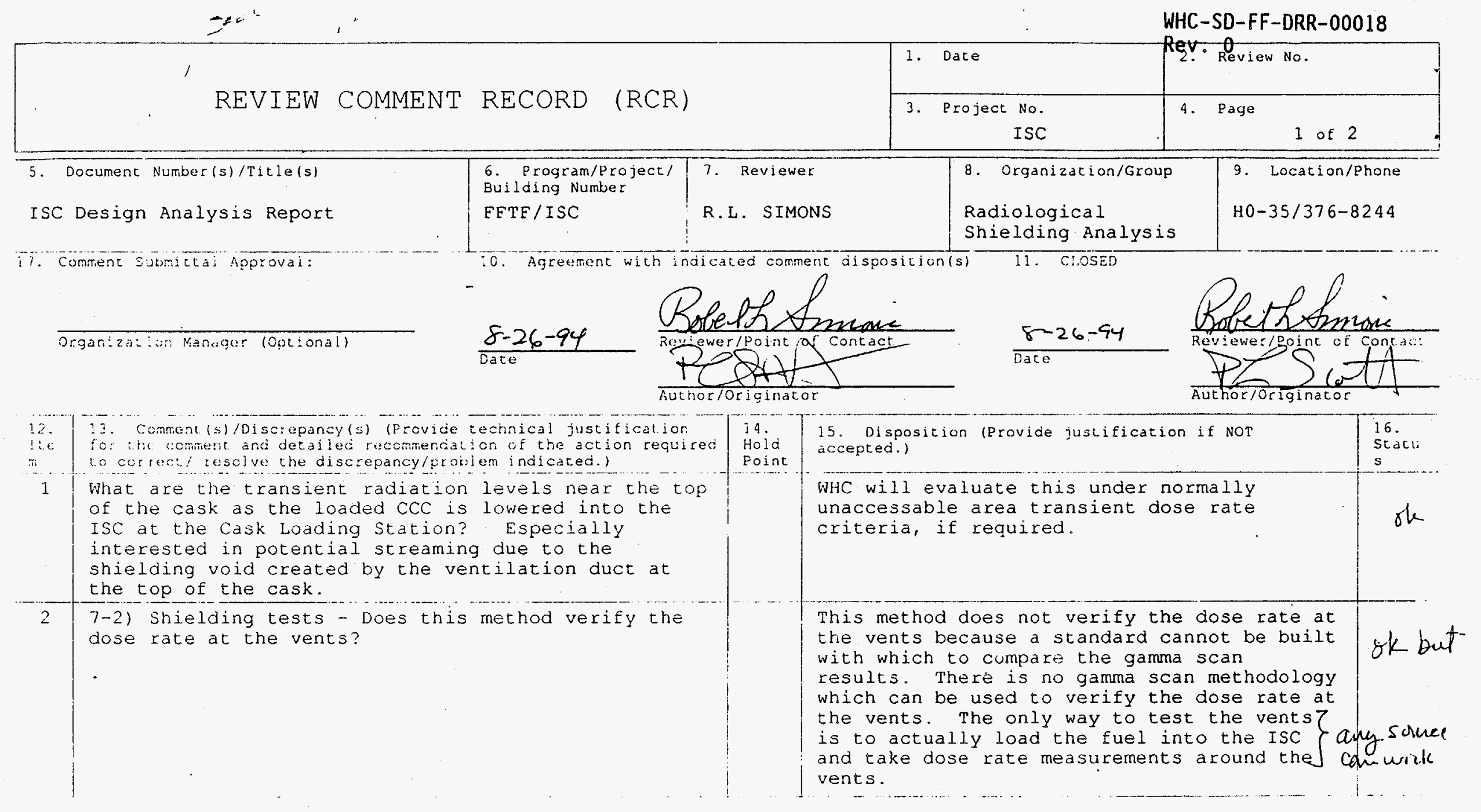


WHC-SD-FF-DRR-00018

\begin{tabular}{|l|l|l|l|l|}
\hline \multirow{2}{*}{ REVIEW COMMENT RECORD } & (RCR) & Date Review No. \\
\cline { 3 - 4 } & $\begin{array}{l}3 . \text { Project No. } \\
\text { ISC }\end{array}$ & 4. Page 2 of 2 \\
\hline
\end{tabular}

12. 13. Comment(s)/Discrepancy (s) (Provide technical justification ite For the comment and detailed recommendation of the action requirec to correct/ resolve the discrepancy/problem indicated.)

$\begin{aligned} & 14 \\ & \text { Hold } \\ & \text { Point }\end{aligned} \mid$

There are two concerns with the PATH correction

factor calculation presented in Section 5.0. First, a ratio of calculated to measured radiation levels for the VSC-24 and MTC casks is reported as 3.1

What assurance do we have that the actual radiation source that was present in the casks during the measurements was actually the maximum as was probably assumed in the calculations? It seems credible that the actual radiation source was much less than assumed in the shielding code

calculations. For example, the radiation source specified for the EFTF ISC is larger than most if not all of the actual fuel assemblies. If radiation level measurements were made after fuel assemblies were loaded into the cask, the ratio of calculated to measured radiation levels would probably be substantially greater than one. However, this would not necessarily mean that the shielding code was conservative since other factors, such as, conservatism in the source could also explain the difference. Second, what assurance do we have that the radiation energy spectrum of the source is the same or similar between the VSC-24, the MTC and the ISC?

GA 5.11- The PATH correction factor calculation

presented in section 5.0 is for the actual fuel loaded in the vSC-2a at che palisades Nuclear station (Ref. $5-6$ co Design hnalysis Report). The fuel source cerms used cooled fuel, which represents the average burnup and cooling lime of the Eue! loaded in the cask. The burnup calculations performec by the reactor caners are burnu: credicr start-uo reactivicy and the startuo reactivicy must be within $\pm 1 \%$ in keff. This gives high confidence that the burnup predictions are accurate. EPRI/DOE have also measured assembly burnups using the FORK

measurement system at the Oconee Nuclear Station of the Duke Power Company Using the Fork Measurement System," High Level Radicactive Waste Management Proceedings Vol. 2, 1994). The results of the measurements show that the assembly burnup from the plant records are. within $\pm 2.2 \%$ of the measured values. Therefore it may be concluded that the scurce used to decermine the correction factor is consistent with the source in the measured cask. Pages. 5.5-17 and 18 of the Design Analys is Report explain how the correction factor is determined for the ISC cask. The difference between the factor of 2 used for the ISC and the factor of 3.1 found with the MCNP code for the VSC-24 cask is due to the difference in relative concrete and steel rhicknesses in the two cask designs. The ficure (see 5-1) show. that the gamma spectra for the two fuel rypes are very similar. The FFTE spectrum is someshat harder. However, this will have little eifecr on the ratio of measured to caiculated dose rates because the gama absorption and scattering cross sections and the flux to dose rate conversion factors are very well behaved.

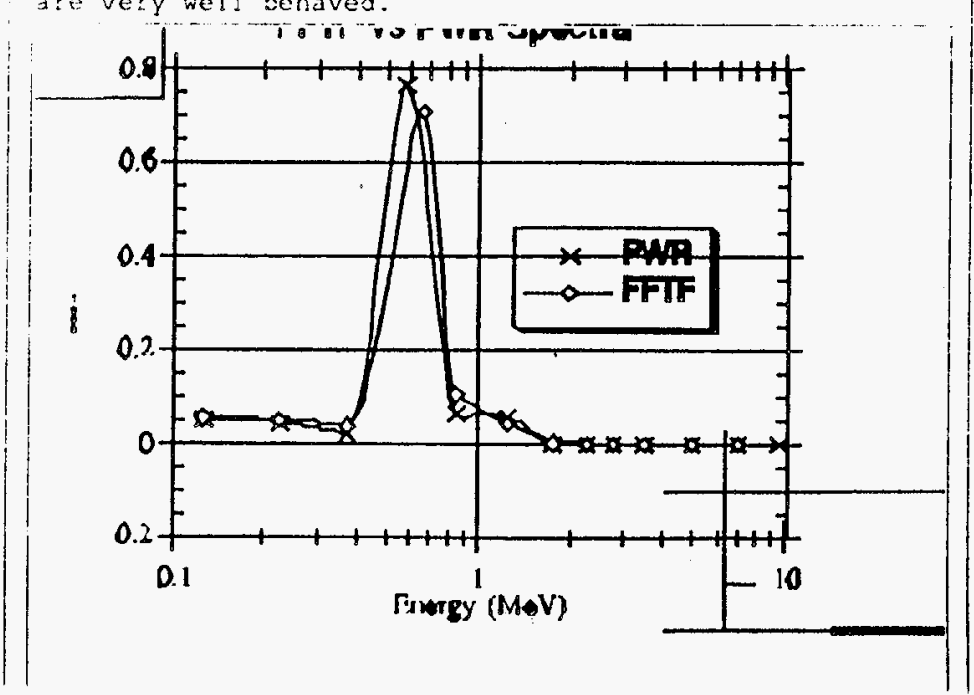


WHC-SD-FF-DRR-00018

\section{REVIEW COMMENT RECORD (RCR)}

1. Date
July 8, 1994

3. Project No.

General Atomics 3682

\section{ReV Review No.}

4. Page

1 of 2

\begin{tabular}{l|l|l|l|l}
\hline 5. Document Number(s)/Title(s) & $\begin{array}{l}\text { 6. Program/Project/ } \\
\text { Building Number } \\
\text { General Atomics } \\
\text { Project 3682 }\end{array}$ & 7. Reviewer & PC Miller & Organization/Group \\
$\begin{array}{l}\text { FFTF Spent Fuel Interim Storage Cask } \\
\text { Design Analysis Report }\end{array}$ & $\begin{array}{l}\text { FFTF Regulatory } \\
\text { Compliance, FFTF } \\
\text { Operations }\end{array}$ \\
\hline
\end{tabular}

17. Comment Submittal Approval: Organization Manager (Opt ional)

10. Agreement with indicated comment disposition(s)

Date

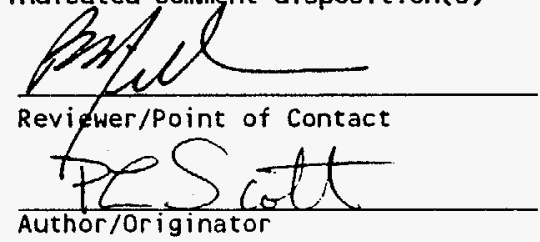

11. CLOSED

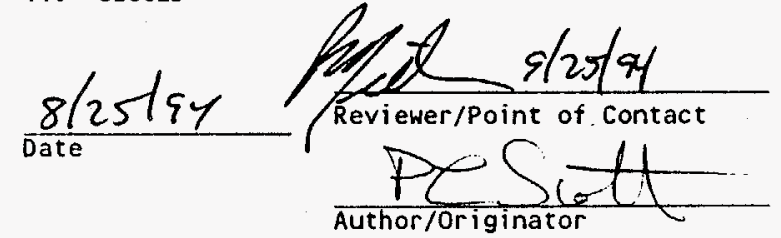




\begin{tabular}{|c|c|c|}
\hline \multirow{2}{*}{ REVIEW COMMENT RECORD (RCR) } & $\begin{array}{l}\text { 1. Date } \\
\text { July } 8,1994\end{array}$ & Rev Rellew no. \\
\hline & $\begin{array}{l}\text { 3. Project No. } \\
\text { General Atomics } 3682\end{array}$ & 4. Page 2 of 2 \\
\hline
\end{tabular}

\begin{tabular}{|c|c|c|c|c|}
\hline $\begin{array}{l}12 . \\
\text { I tem }\end{array}$ & $\begin{array}{l}\text { 13. Comment( }(s) / 0 i s c r e p a n c y(s) \text { (Provide technical justification for the } \\
\text { comment and detailed recommendation of the action required to correct/ } \\
\text { resolve the discrepancy/problem indicated.) }\end{array}$ & $\begin{array}{l}14 . \\
\text { Hold } \\
\text { Point }\end{array}$ & 15. Disposition (Provide justification if NOT accepted.) & $\begin{array}{l}16 . \\
\text { status }\end{array}$ \\
\hline 1 & $\begin{array}{l}\text { Section } 2.10 \text { CRITICALITY CONTROL. This sections } \\
\text { states "Criticality Control is not a part of this } \\
\text { report or the cask design." This section is not } \\
\text { consistent with DOE directives provided below. } \\
\text { RLID } 5820.2 A \text {, Radioactive Waste Management, Chapter } \\
\text { II, Management of Solid Transuranic Waste, Section } \\
\text { 2, POLICY states "Reactor irradiated research } \\
\text { materials, and irradiated fuels that are destined } \\
\text { for disposal which exceed the } 100 \text { nCi/gm TRU limit } \\
\text { shall be handled as TRU waste." Subsection e. of } \\
\text { Section } 2 \text { states "All activities involving TRU waste } \\
\text { shall be controlled with criticality prevention } \\
\text { specifications." } \\
\text { It is my understanding that analysis was performed } \\
\text { during early stages of cask design development. } \\
\text { This analysis, if done, "should be included in } \\
\text { Section } 2.10 \text { of the Design. Report (at least by } \\
\text { reference). } \\
\text { If the intent is to not include criticality control } \\
\text { analysis, then a waiver to RLID 5820.2A, Chapter II, } \\
\text { Section } 2 . e \text { should be obtained. } \\
\text { Disposal of the fuei may be decades away but it does } \\
\text { meet the requirements for classification as TRU } \\
\text { Waste. }\end{array}$ & & $\begin{array}{l}\text { Criticality control has been addressed by } \\
\text { WHC analysts as part of the overall Spent } \\
\text { Fuel offload project. This Design Analysis } \\
\text { Report DAR is only a part of the technical } \\
\text { basis for the ISC/CCC Spent Fuel Offload } \\
\text { system. The WHC critical ity analyses, along } \\
\text { with this DAR, will be included as technical } \\
\text { bases and references when the FSAR is } \\
\text { revised. }\end{array}$ & \\
\hline
\end{tabular}


WHC-SD-FF-DRR-00018

\section{REVIEW COMMENT RECORD (RCR)}

\begin{tabular}{|c|l|}
\hline $\begin{array}{l}\text { 1. Date } \\
7 / 28 / 94\end{array}$ & $\begin{array}{r}\text { ReV Review No. } \\
94-002-S L M\end{array}$ \\
\hline $\begin{array}{c}\text { 3. Project No. } \\
\text { ISC }\end{array}$ & 4. Page \\
\hline
\end{tabular}

5. Document Number(s)/Title(s)

ISC Final Design

17. Comment Submittal Approval:

\section{N/A}

Organization Manager (Optional)

6. Program/Project/

Building Number

FFTF/ISC

10. Agreement with indicated comment disposition(s)

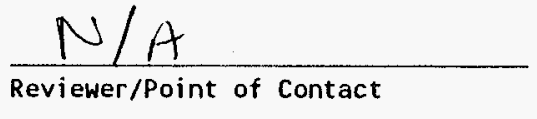

Date
7. Reviewer

S.L. Mischke
8. Organization/Group 38550/FFTF QA
9. Location/Phone

$4702 / \mathrm{Rm} .11$ 376-9143
11. CLOSED

$N / A$

Date Reviewer/Point of Contact

Author/Originator

\begin{tabular}{|c|c|c|c|c|}
\hline $\begin{array}{l}12 . \\
\text { Item }\end{array}$ & $\begin{array}{l}\text { 13. Comment }(s) / D i s c r e p a n c y(s) \text { (Provide technical justification for the } \\
\text { comment and detailed recommendation of the action required to correct/ } \\
\text { resolve the discrepancy/problem indicated.) }\end{array}$ & $\begin{array}{l}14 . \\
\text { Hold } \\
\text { Point }\end{array}$ & 15. Disposition (Provide justification if NOT accepted.) & $\begin{array}{l}16 . \\
\text { Status }\end{array}$ \\
\hline 1 & ISC Design Analysis Report - no comments & & & \\
\hline 2 & H-4-302135, ISC Assembly Drawing - no comments & & & \\
\hline 3 & $\begin{array}{l}\text { H-4-302134, ISC Outline/Interface Drawing - no } \\
\text { comments }\end{array}$ & & & \\
\hline 4 & H-4-302136, ISC Tiedown System Drawing - no comments & & & \\
\hline & & & & \\
\hline & & & & \\
\hline
\end{tabular}

$\frac{1}{5}$ 
WHC-SD-FF-DRR-00018

REVIEW COMMENT RECORD (RCR)

\begin{tabular}{|c|c|}
\hline $\begin{array}{c}\text { 1. Date } \\
7 / 26 / 94\end{array}$ & \multicolumn{2}{|l|}{ Final } \\
\hline $\begin{array}{c}\text { 3. Project No. } \\
\text { FFTF }\end{array}$ & 4. Page \\
\hline
\end{tabular}

\begin{tabular}{l|l|l|}
\hline 5. Document Number(s)/title(s) & $\begin{array}{l}\text { 6. Program/Project/ } \\
\text { Building Number } \\
\text { FFTF/ISC }\end{array}$ & $\begin{array}{l}\text { 7. Reviewer } \\
\text { S. W. Hiller }\end{array}$ \\
\hline
\end{tabular}

17. Comment Submittal Approval:

10. Agreement with indicated comment disposition(s)

9. Location/Phone

IEM Cell \& Refueling

Mechanical

Engineering

N2-02/376-5769

Organization Manager (Optional)

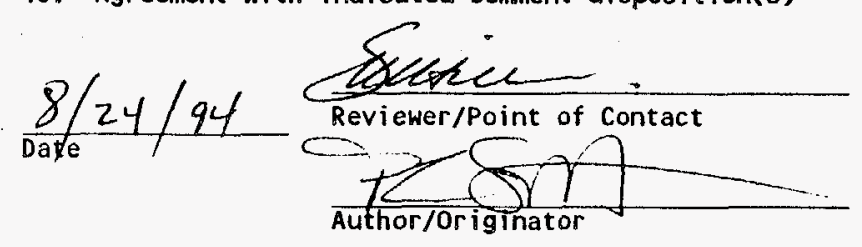

11. CLOSED

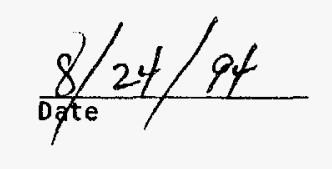

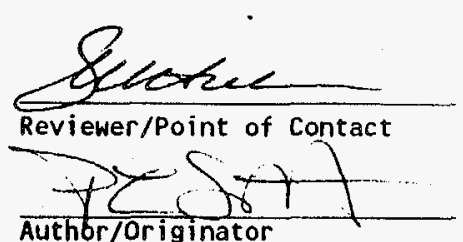
Authbr/ariginator

\begin{tabular}{|c|c|c|c|c|}
\hline $\begin{array}{l}12 . \\
\text { I tem }\end{array}$ & $\begin{array}{l}\text { 13. Comment(s)/Dis repancy(s) (Provide technical justification for the } \\
\text { comment and detailew recommendation of the action required to correct/ } \\
\text { resolve the discrepancy/problem indicated.) }\end{array}$ & $\begin{array}{l}14 \\
\text { Hold } \\
\text { Point }\end{array}$ & 15. Disposition (Provide justification if NOT accepted.) & $\begin{array}{l}16 . \\
\text { Status }\end{array}$ \\
\hline 1 & $\begin{array}{l}\text { 10-1) There is no method defined to } 1 \text { ift the } \\
\text { tie-down equipment for placement on the cask. Need } \\
\text { rigging attachment points. }\end{array}$ & & $\begin{array}{l}\text { Lifting eyes will be added to top x-brace to } \\
\text { provide improved lifting and handling } \\
\text { capability. Tie down system could be fully } \\
\text { assembled and draped over top of cask, or } \\
\text { separated at top or bottom end of item } 6 \\
\text { links. Over-rotation of joints is prevented } \\
\text { by "stop bar" (item } 24 \text { of H-4-302126), } \\
\text { welded to top clevice assy (item 15). }\end{array}$ & fes \\
\hline 2 & 10-2) Item 17 does not fit inside item 26. & & Will revise drawing. & Clade. \\
\hline 3 & $\begin{array}{l}\text { 10-3) Parts } 4 \text { and } 29 \text { do not have lock pins as shown } \\
\text { on the DSWC tie-down equipment so that torquing is } \\
\text { not required to keep nut from coming off - allows } \\
\text { easier assembly. (See H-4-65160 ECN-A53412) }\end{array}$ & & $\begin{array}{l}\text { OK, will incorporate lock pins to be } \\
\text { consistent with WHC design. }\end{array}$ & Close \\
\hline
\end{tabular}

$\frac{7}{1}$ 
WHC-SD-FF-DRR-00018

\begin{tabular}{|c|c|c|}
\hline & $\begin{array}{l}\text { 1. Date } \\
7 / 26 / 94 \\
\end{array}$ & $\begin{array}{l}\text { 2. Review No. } \\
\text { Final }\end{array}$ \\
\hline REVIEW CUMIMEN RECURD (RCK) & $\begin{array}{l}\text { 3. Project No. } \\
\text { FFTF }\end{array}$ & $\begin{array}{l}\text { 4. Page } 2 \text { of } 4 \\
\text { 2 }\end{array}$ \\
\hline
\end{tabular}

\begin{tabular}{|c|c|c|c|c|}
\hline $\begin{array}{l}12 . \\
\text { Item }\end{array}$ & $\begin{array}{l}\text { 13. Comment(s)/Discrepancy(s) (Provide technical justification for the } \\
\text { comment and detailed recommendation of the action required to correct/ } \\
\text { resolve the discrepancy/problem indicated.) }\end{array}$ & $\begin{array}{l}14 . \\
\text { Hold } \\
\text { Point }\end{array}$ & 15. Disposition (Provide justification if NOT accepted.) & $\begin{array}{l}16 . \\
\text { Status }\end{array}$ \\
\hline 4 & $\begin{array}{l}\text { 6-4) ECN } 152263 \text { for drawing } \mathrm{H}-4-65152 \text { shows insert } \\
\text { tubing is used with the } 1 \text { 1/2" HEX Head bolts to } \\
\text { attach the center plate to the DSWC Trailer. Please } \\
\text { add this to the bolt assembly for the ISC center } \\
\text { plate also. }\end{array}$ & & $\begin{array}{l}\text { Will add inserts to ISC plate bolting. } \\
\text { (Note that incorporation of the tightly } \\
\text { toleranced bolts in the existing trailer } \\
\text { bolt holes requires "match-drilling" of the } \\
\text { ISC plate and tiedown mounting lugs per dwg. } \\
\text { note 14) }\end{array}$ & Cloved \\
\hline 5 & $\begin{array}{l}\text { 6-5) 8.0, Tie-down design, ASTM A-514 (Fy }=100 \\
\text { ksi) listed for plates, drawing lists ASTM A-36 as } \\
\text { the material. This affects parts } 17,18 \text { and } 20 \text {. }\end{array}$ & & $\begin{array}{l}\text { Will revise drawing to match design } \\
\text { calculations. }\end{array}$ & Closed \\
\hline 6 & $\begin{array}{l}\text { 10-5) All load bearing welds need mag. particle } \\
\text { inspection. }\end{array}$ & & $\begin{array}{l}\text { This is a new requirement, not presently } \\
\text { included in the WHC specification for } \\
\text { non-safety related handling equipment. The } \\
\text { tiedown system is not safety-related since } \\
\text { the cask can withstand drops if the tiedowns } \\
\text { fail, therefore mag. particle inspection is } \\
\text { not required. Should you wish to add this } \\
\text { requirement, GA will provide a fixed price. }\end{array}$ & Closed \\
\hline 7 & $\begin{array}{l}\text { Concurrence with Appendix A. Re-write of Cask } \\
\text { Handling Operations at RSB-CLS. }\end{array}$ & & & \\
\hline & & & & \\
\hline & & & & \\
\hline & & & & \\
\hline & & & & \\
\hline$\frac{1}{2}$ & & & & \\
\hline
\end{tabular}


WHC-SD-FF-DRR-00018

\begin{tabular}{|l|l|l|l|}
\hline \multirow{2}{*}{ REVIEW COMMENT RECORD (RCR) } & $\begin{array}{l}\text { Date } \\
8 / 17 / 94\end{array}$ & $\begin{array}{l}\text { ReV Review No. } \\
\text { ISC Project No. } \\
\text { ISC }\end{array}$ & $\begin{array}{l}\text { 4. Page } \\
1 \text { of } 3\end{array}$ \\
\hline
\end{tabular}

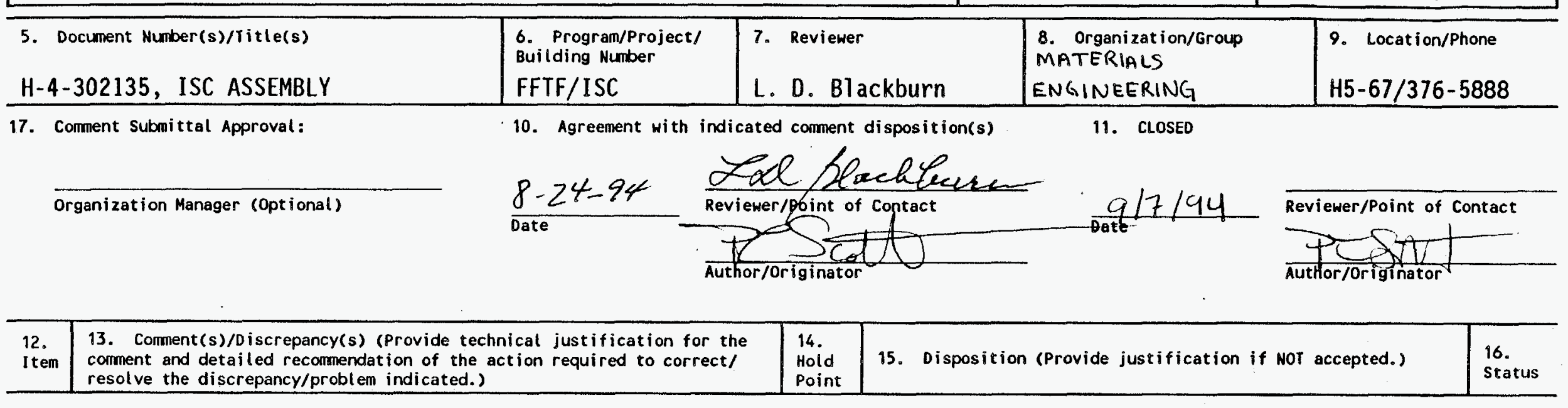

\footnotetext{
$D$

o

n

N
} 


\begin{tabular}{|c|c|c|}
\hline & $\begin{array}{r}\text { 1. Date } \\
8 / 17 / 94 \\
\end{array}$ & $\begin{array}{r}\text { Review No. } \\
1\end{array}$ \\
\hline REVIEW COMIMIN I RECORD (RCK) & $\begin{array}{l}\text { 3. Project No. } \\
\text { ISC }\end{array}$ & $\begin{array}{l}\text { 4. Page } \\
2 \text { of } 3\end{array}$ \\
\hline
\end{tabular}

1 There is insufficient information on the drawings to fully understand the criteria and implementation for brittle fracture protection. Therefore basic

implementation is assumed to be correct.
GA will provide the underlined clarifications to the DAR text as follows:

Page 3.3-3

The 1.5 inch cylinder and $f$ lange will be fabricated from $\mathrm{A}_{203}$ Grade $E$ with NDT $<-87^{\circ} \mathrm{F}$. Per Reg. Guide 7.11 this will meet requirements without performing a flaw-size/configuration versus stress level analysis. (Ref. Reg. Guide 7.11, fig. 3, versus stress level analysis. (Ref. Reg. Guide 7.11, Fig. Design Chart for Category I fracture critical components). Full dynamic loading is assumed for the 1.5 inch cylinder. A reduced loading rate is justified for the flange due to the dynamic response of the structure as demonstrated in sect ion 3.5 .3 of the DAR. SReference: page 15 section 5.1 .2 of NUREG CR-1815.

Second Paragraph

The rest of the confinement barrier (closure item 2 and bottom head item 6) will have a NDT $<-50^{\circ} \mathrm{F}$. These will be

volumetrically examined by both straight and angle beam

ultrasonic method. ASTM A-578/577. Angle beam examination

will show that there are not flaws larger than $0.8 \mathrm{in}$. unless straight beam method shoes the imperfections are laminar in nature and are acceptable in accordance with ASTM A-578. In addition, straight beam examination will show that laminar indications are enconpassed within a circle whose dianter indications are enconpassed within a circle whose dianete one-half of the plate thickness. Ine flaw size of 0.8 inches is based on fracture mechanics calculations showing that fracture propagation from a flaw of this size is not possible (see section 3.5 .5 of DAR) under the hypothet ical accident conditions described in WHC-S-4110.

The port cover plates will have a NDT of $<-40^{\circ} \mathrm{F}$.

GA - Values in Table 3 of NUREG/CR-1815

typically give conservative values because they are based on using the upper bound values to show the material meets toughness criteria without additional testing. Our manufacturer chose A-516 GR 70 given the NDT temperature requirement of $-50{ }^{8} \mathrm{~F}$. 
3 9-16) One of the comments under note 4 imposes special NDT requirements on Items 11 and 12 , but in the Parts List, only Item 12 is marked with the mark of note 4. It would seem to be in error in the Parts list that Item 11 is not marked with the 4.

4 9-17) Along same line as comment 9-16 above, is it really intended that Item 7 in the parts list is not subject to note 4 , or is there an omission? If there is not an error in the Parts List, the implication is that brittle fracture protection is not as important for Item 7 . Is this true?

5 9-18) The use of Note 37 for Item 3 on the Parts List is not clear. The basic selection of $A 516$ is without any restriction on NDT (i.e. could be +30 degrees $F$ ), yet there is requirement for full UT, and the alternate material (A203) is expected to have a much lower NDT.

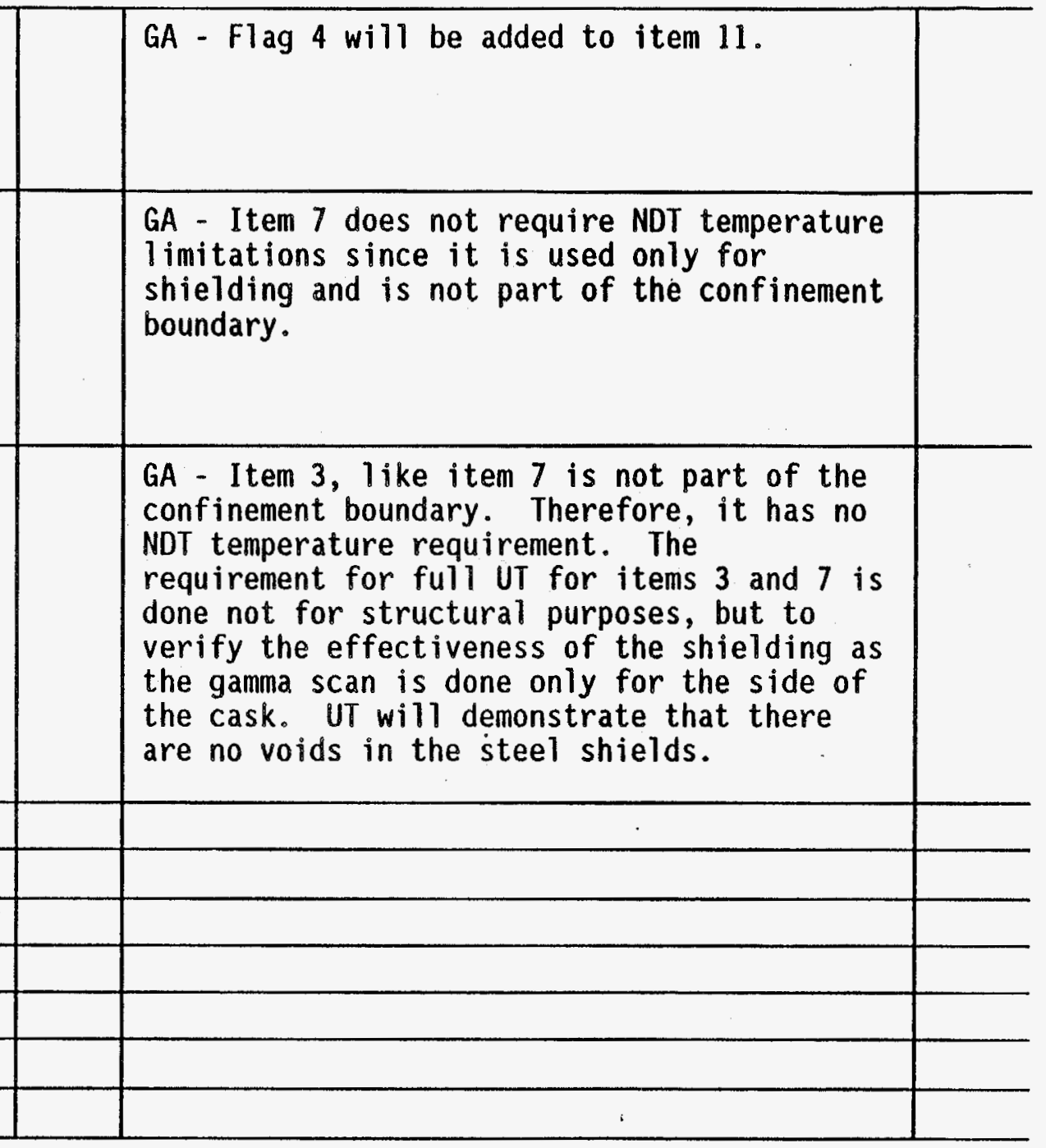

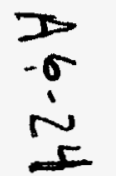




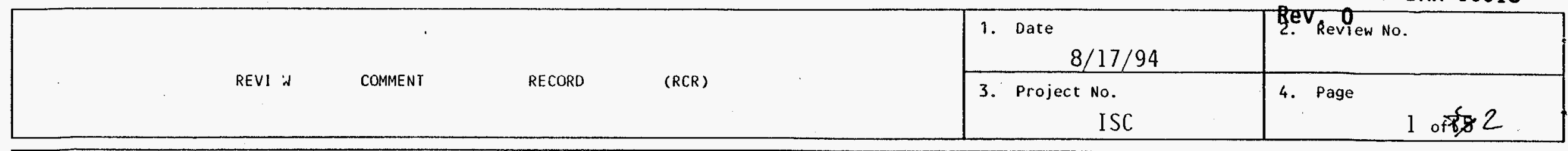

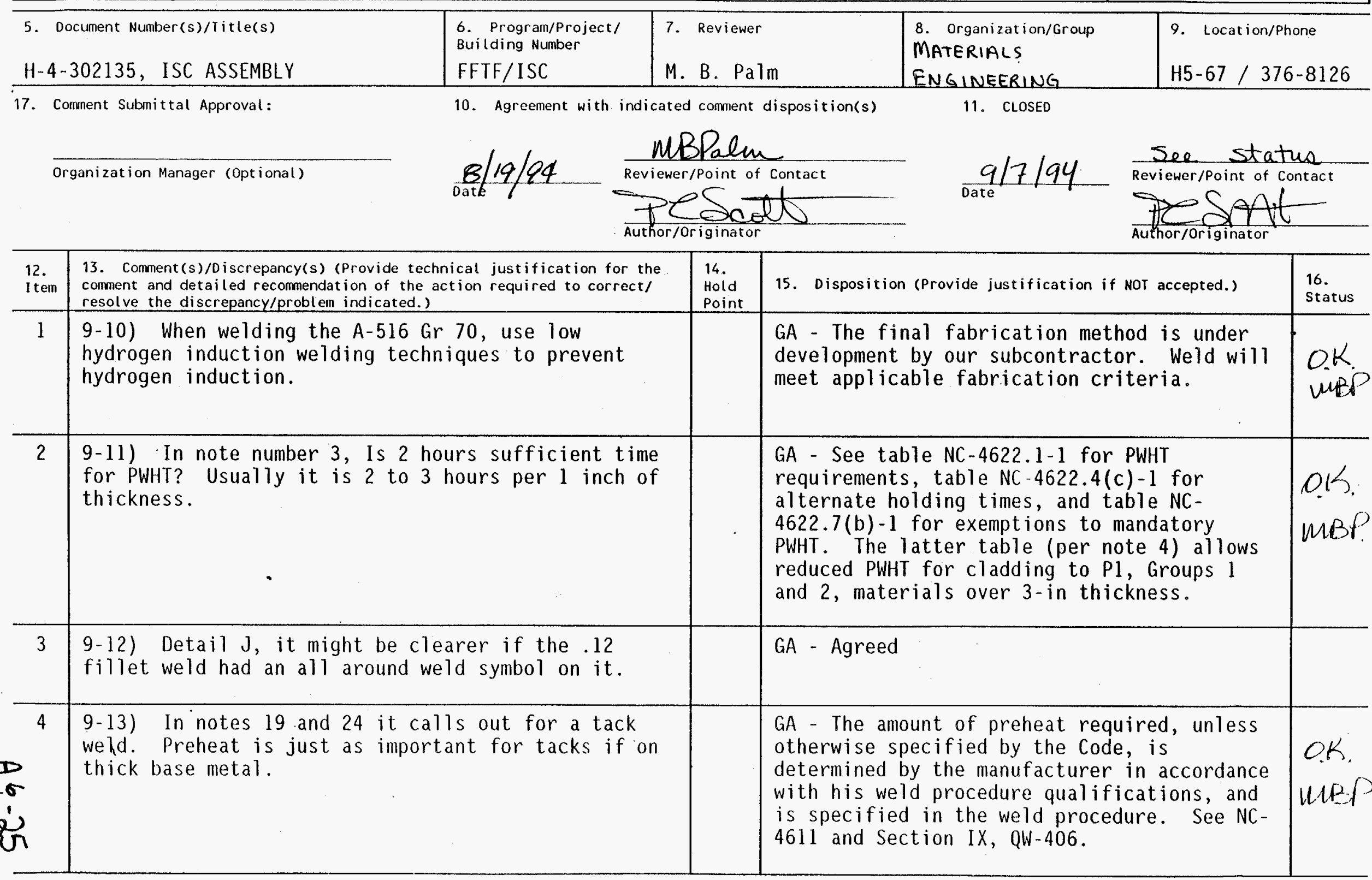


WHC-SD-FF-DRR-00018

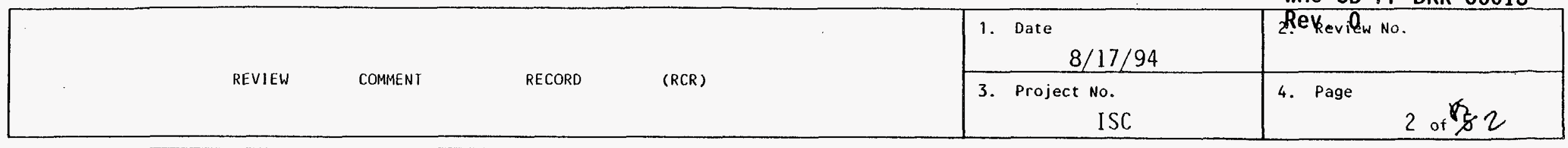

12. 13. Comment(s)/Discrepancy(s) (Provide technical justification for the Item comment and detailed recommendation of the action required to correct/ resolve the discrepancy/problem indicated.)

\begin{tabular}{|c|c|c|}
\hline $\begin{array}{l}14 . \\
\text { Hold } \\
\text { Point }\end{array}$ & 15. Disposition (Provide justification if NOT accepted.) & $\begin{array}{l}16 . \\
\text { Status }\end{array}$ \\
\hline & $\begin{array}{l}\text { GA will provide as soon as subcontractor can } \\
\text { supply them. } \\
\text { WHC/FFTF - We will request your support in } \\
\text { reviewing the fabrication plans and welding } \\
\text { nrocedures These are exnected } 8 / 17 / 94 \text { and }\end{array}$ & 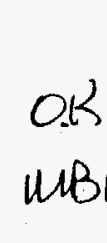 \\
\hline
\end{tabular}

5 9-14) WHC needs to review and approve GA's Welding Procedure Specifications (WPS's), Procedure Qualification ecords (PQR's) and Welder

Qualification Records (WQR's). Will these be provided with the fabrication plan?

will be provided to you as soon as we

receive them. WHC approval for fabrication

is required by $9 / 16 / 94$ to support General

Atomic's Contract schedule. 


\section{REVIEW COMMENT RECORD (RCR)}

\begin{tabular}{|c|l|}
\hline \begin{tabular}{|l|l|} 
1. Date \\
$8 / 2294$
\end{tabular} & \multicolumn{1}{|l|}{ Fiev Review No. } \\
\hline $\begin{array}{c}\text { 3. Project No. } \\
\text { FIF }\end{array}$ & 4. Page 1 of 10 \\
\hline
\end{tabular}

5. Document Number(s)/Title(s)

FFTF Spent Fuel Interim Storage Cask Design Analysis Report by General Atomics, June 1994

17. Comment Submittal Approval:

Organization Manager (Optional)

\begin{tabular}{l|l}
\hline $\begin{array}{l}\text { 6. Program/Project/ } \\
\text { Building Number } \\
\text { FFTF/ISC }\end{array}$ & 7. Reviewer \\
& P.L. SCOTT
\end{tabular}

10. Agreement with indicated comment disposition(s)

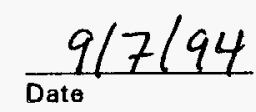

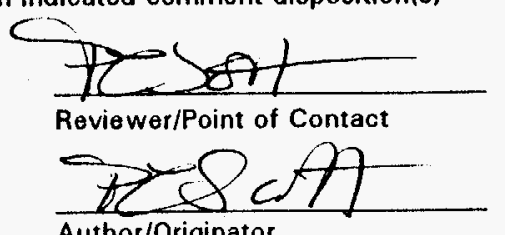

9. Location/Phone

$\mathrm{N} 2-02$

\section{$376-4219$}

Mechanical

Engineering

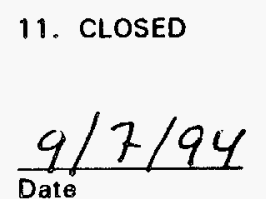

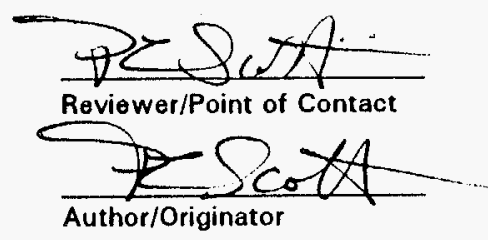

12. 13. Comment(s)/Discrepancy(s) (Provide technical justification for the comment and detailed recommendation of the action required to correct/ resolve the discrepancy/problem indicated.)

1 1-1) 1.2.1 first paragraph - clarify the radiation dose rates are limited to $2 \mathrm{mRem} / \mathrm{hr}$ at ISC surface when the CCC is in the stored position.

2 1-2) 1.2.1 add statement to cover tie-down equipment weight and trailer payload.

\section{4.} Hold Point

15. Disposition (Provide justification if NOT accepted.)

The words "when the CCC is in the stored position" will be added to the last sentence of the first paragraph in Section 1.2.1

The following words have been added to Section 1.2.3:

"The tiedown equipment used in the lowboy to transport the cask weighs $3883 \mathrm{lbs}$. The total lowboy trailer payload including the cask and tiedown equipment is 117,823 lbs."

3 1-3) The operations section is not totally clear. Sketches are needed to facilitate the discussion.

1-4)1.3.1, Need to address the sequence of operation required with the Cask Loading Station shielding and sealing equipment and DSWC plug handling fixture. Include step that allows

I closure to sit on DSWC Floor valve. Describe how the existing

- 6 tooling and interface equipment is used to accomplish closure

installation per 3.2.4.4 of specification. Identify additional

a) tooling required to accomplish the closure installation. Sketches $\rightarrow$ would be useful.

Section 1.3 has been revised as shown in appendix $\mathrm{A}$. 
WHC-SD-FF-DRR-00018

\section{REVIEW COMMENT RECORD (RCR)}

\begin{tabular}{|c|c|}
\hline $\begin{array}{c}\text { 1. Date } \\
8 / 2294\end{array}$ & $\begin{array}{l}\text { Reg. Review No. } \\
\text { Fnd }\end{array}$ \\
\hline $\begin{array}{c}\text { 3. Project No. } \\
\text { FIF }\end{array}$ & 4. Page 2 of 10 \\
\hline
\end{tabular}

12. 13. Comment(s)/Discrepancy(s) (Provide technical justification for the comment and

Item detailed recommendation of the action required to correct/ resolve the discrepancy/problem indicated.)

5 1-5) 1.3.2, Need to address the sequence of operation required with the Cask Loading Station sealing and shielding equipment and DSWC plug handling fixture. Need to demonstrate how the design complies with section 3.2.5.6 of the specification. Identify additional equipment required to accomplish closure removal. Expand on the port cover removal requirements and replacement and if any precautions need to be observed during removal process. Sketches would be useful. How is closure removed if leak of CCC is discovered?

$6 \quad 1-6)$ Expand the Leakage Testing section to include industry accepted evacuation and backfill practice to verify dry inert gas. Recommend what pressures the evacuations and backfills need to be performed at. A recommendation of a method of inter-seal monitoring would also be useful.

7 1-7) 1.3.6, Unclear how tie-down equipment will be hoisted and placed on If $?$. In what state of assembly. Sketch would be useful.

\begin{tabular}{|c|c|c|}
\hline $\begin{array}{l}14 . \\
\text { Hold } \\
\text { Point }\end{array}$ & 15. Disposition (Provide justification if NOT accepted.) & $\begin{array}{l}16 . \\
\text { Status }\end{array}$ \\
\hline & Section 1.3 has been revised as shown in appendix $A$. & C \\
\hline & Section 1.3 has been revised as shown in appendix $A$. & C \\
\hline & $\begin{array}{l}\text { Lifting eyes will be added to top x-brace to provide } \\
\text { improved lifting and handling capability. Tie down } \\
\text { system could be fully assembled and draped over top of } \\
\text { cask, or separated at top or bottom end of item } 6 \text { links. } \\
\text { Over-rotation of joints is prevented by "stop bar" (item } \\
24 \text { of H-4-302126), welded to top clevice assy (item } \\
\text { 15). }\end{array}$ & Sut. \\
\hline & $\begin{array}{l}\text { The text in Section } 1.3 .8 \text { item } 4 \text { has been changed to } \\
\text { read: } \\
4 \text {. Thread wires through two cover bolts to nearby } \\
\text { holes in the cover; crimp wires with tamper-indicating } \\
\text { seals. }\end{array}$ & C \\
\hline & $\begin{array}{l}\text { No, there is no detriment to the cask, thermally or } \\
\text { otherwise. }\end{array}$ & \\
\hline
\end{tabular}

r

1-9) 1.4 , Is there action required to remove snow? otherwise. 


\section{REVIEW COMMENT RECORD (RCR)}

\begin{tabular}{|c|l|}
\hline $\begin{array}{l}\text { 1. Date } \\
8 / 22 / 94\end{array}$ & $\begin{array}{c}\text { Rev Review No. } \\
\text { Fnal }\end{array}$ \\
\hline $\begin{array}{c}\text { 3. Project No. } \\
\text { FIF }\end{array}$ & 4. Page \\
\hline
\end{tabular}

12. 13. Comment(s)/Discrepancy(s) (Provide technical justification for the comment and

Item detailed recommendation of the action required to correct/ resolve the

discrepancy/problem indicated.

10 1-10) Need to include discussion on the recommended annulus boroscope inspection and duct and/or annulus cleaning.

\section{4.}

Hold
Hold

15. Disposition (Provide justification if NOT accepted.)

The following will be added to the end of section 1.4.

As an added precaution, if desired, the ducts and/or annulus can be cleaned by removing the expansion anchor bolts and duct screens and vacuuming and/or blowing air though the ducts. Since the ACI-349 long term temperature limitations are met even with the ducts plugged (see Chapter 4), there is no need to clean the ducts on a regular basis.

WHC may want to inspect the ducts and annulus with a boroscope before the cask is transported after being stored outside for a long period of time. This may be done by removing the duct screens and inserting a boroscope to view the inside of the duct system. This inspection is not required because of the low cask temperatures, as discussed above.

11 1-11) Is there any criteria that $\mathrm{GA}$ would recommend in regards to duct outlet temperature monitoring, if not, discuss the basis for not performing this.

12 1-12) Need to address requirements for cavity sampling. Port cover removal requirements and replacements and any precautions. Address that the port cover removal and installation operations do not affect the closure seals.

13 2-1) 2.2, Closeu CCC reference should be H-4-72005.

There is no need to monitor duct outlet temperature since the ACl-349 long-term temperature limitations are met even with the ducts plugged (see Chapter 4).

See Section 1.3.4 in appendix A. The port cover removal and installation operations if properly performed do not affect the closure seals.

\section{This drawing number is not in the WHC-S-4110} specification. The drawing number will be removed from Section 2.2. 


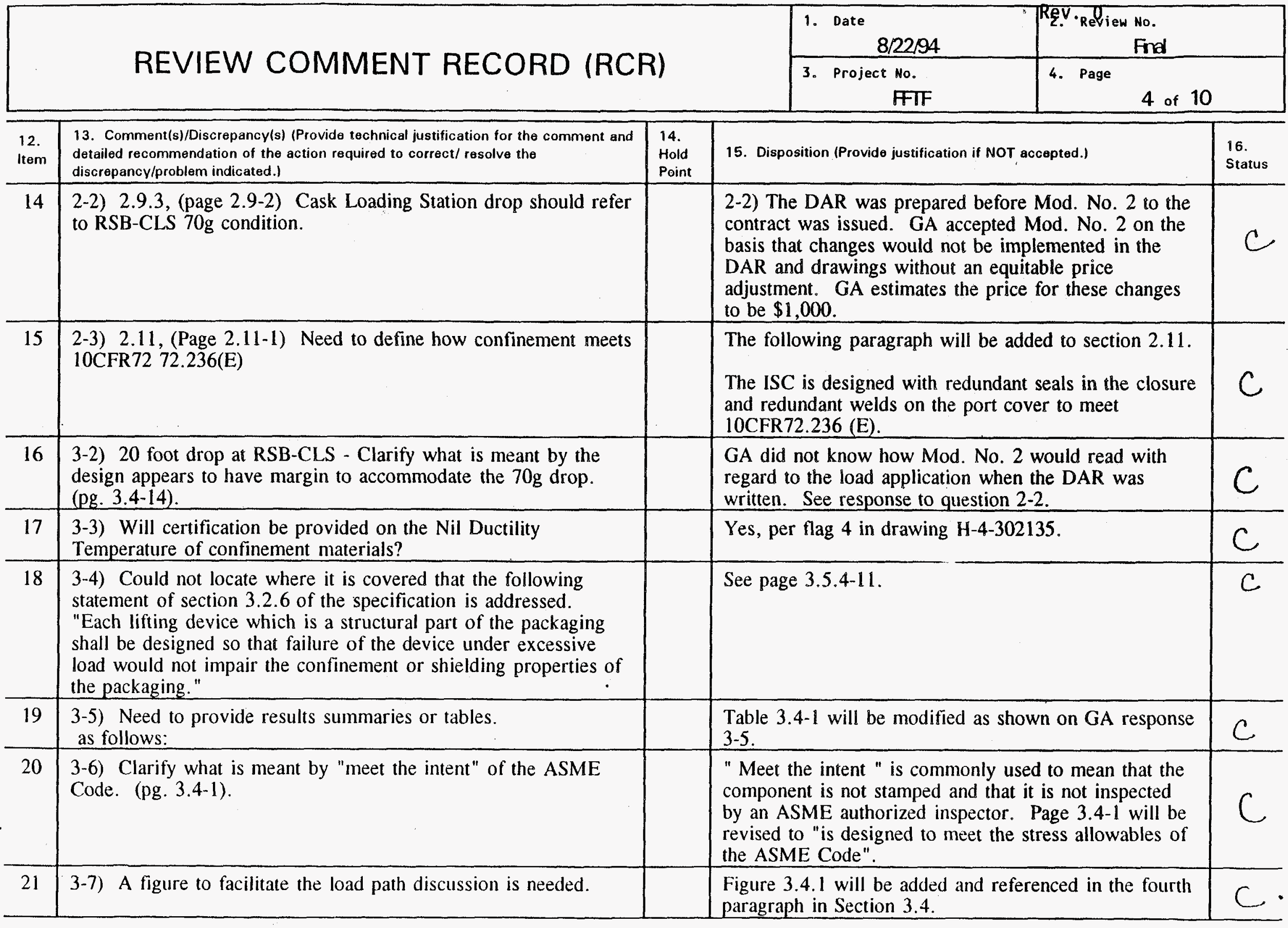




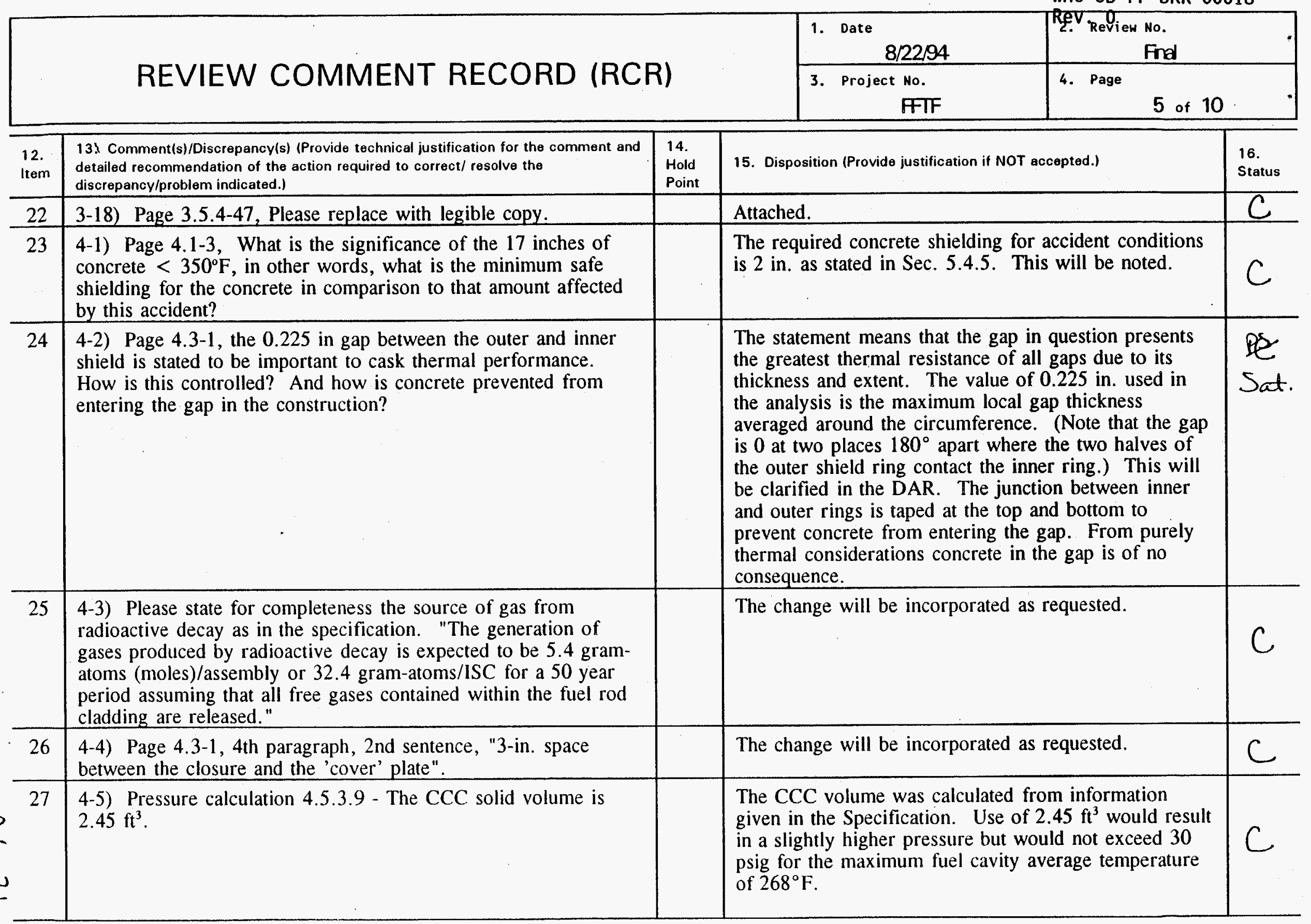


WHC-SD-FF-DRR-00018

\section{REVIEW COMMENT RECORD (RCR)}

\begin{tabular}{|c|l|}
\hline $\begin{array}{l}\text { 1. Date } \\
8 / 2294\end{array}$ & $\begin{array}{l}\text { Rev. Review No. } \\
\text { Fna }\end{array}$ \\
\hline $\begin{array}{c}\text { 3. Project No. } \\
\text { FIF }\end{array}$ & 4. Page \\
\end{tabular}

\begin{tabular}{|c|c|c|c|c|}
\hline $\begin{array}{l}12 . \\
\text { Item }\end{array}$ & $\begin{array}{l}\text { 13. Comment(s)/Discrepancy(s) (Provide technical justification for the comment and } \\
\text { detailed recommendation of the action required to correct/ resolve the } \\
\text { discrepancy/problem indicated.) }\end{array}$ & $\begin{array}{l}14 . \\
\text { Hold } \\
\text { Point }\end{array}$ & 15. Disposition (Provide justification if NOT accepted.) & $\begin{array}{l}16 . \\
\text { Status }\end{array}$ \\
\hline 28 & $\begin{array}{l}\text { 5-4) Shielding - How are you controlling the concrete minimal } \\
\text { radial thicknesses of } 21.25^{\prime \prime} \text { and } 25.25^{\prime \prime} \text {. }\end{array}$ & & $\begin{array}{l}\text { The concrete minimum radial thickness is controlled by } \\
\text { the fabrication drawings. In addition, following } \\
\text { fabrication, the cask will be gamma scanned to ensure } \\
\text { sufficient shielding is provided. }\end{array}$ & C \\
\hline 29 & $\begin{array}{l}5-5) 5.4 .5 \text {, How does the concrete condition assumed for the } \\
\text { accident dose analysis compare to the worst case hypothetical } \\
\text { accident structural results? }\end{array}$ & & $\begin{array}{l}\text { The following sentence will be added to Section 5.4.5: } \\
\text { The maximum crush of the concrete during a free drop } \\
\text { accident is } 6.19 \text { inches in the corner as given in Table } \\
3.5 .2-8 \text {. This leaves approximately } 19 \text { inches more } \\
\text { concrete than is assumed in the shielding calculations. } \\
\text { The maximum local penetration during a puncture drop } \\
\text { accident is } 11.12 \text { inches as shown in Section } 3.5 .7 .2 \text {. } \\
\text { This leaves at least } 10 \text { inches of concrete which is } 8 \\
\text { inches more than was used in the shielding analysis. }\end{array}$ & \\
\hline 30 & $\begin{array}{l}\text { 6-4) ECN } 152263 \text { for drawing H-4-65152 shows insert tubing is } \\
\text { used with the } 11 / 2 " \text { HEX Head bolts to attach the center plate to } \\
\text { the DSWC Trailer. Please add this to the bolt assembly for the } \\
\text { ISC center plate also. }\end{array}$ & & $\begin{array}{l}\text { Will add inserts to ISC plate bolting. (Note that } \\
\text { incorporation of the tightly toleranced bolts in the } \\
\text { existing trailer bolt holes requires "match-drilling" of } \\
\text { the ISC plate and tiedown mounting lugs per dwg. note } \\
\text { 14) }\end{array}$ & \\
\hline 31 & $\begin{array}{l}\text { 6-5) } 8.0 \text {, Tie-down design, ASTM A-514 (Fy }=100 \mathrm{ksi} \text { ) listed } \\
\text { for plates, drawing lists ASTM A-36 as the material. This } \\
\text { affects parts } 17.18 \text { and } 20 \text {. }\end{array}$ & & Will revise drawing to match design calculations. & Sat. \\
\hline 32 & $\begin{array}{l}\text { 6-6) } 8.2 \text {, Tie-down Trailer Bracket, Base Plate Bending, Section } \\
\text { A-A should use } 8 \text { instead of } 12.5 \text { for b. }\end{array}$ & & Will adjust calculations accordingly. & \\
\hline 33 & $\begin{array}{l}\text { 6-7) } 8.3 \text { Strut Bolt Bending - unable to confirm a } 100 \text { psi Fy for } \\
\text { ASTM A-325. }\end{array}$ & & $\begin{array}{l}100 \mathrm{ksi} \text { allowable is too high. Will revise calcs } \\
\text { accordingly. }\end{array}$ & Sat. \\
\hline
\end{tabular}


WHC-SD-FF-DRR-00018

\begin{tabular}{|c|c|c|}
\hline & $\begin{array}{r}\text { 1. Date } \\
8 / 22 / 94 \\
\end{array}$ & $\begin{array}{l}\text { 2. Review No. } \\
\text { Fina } \\
\end{array}$ \\
\hline REVIEV COIVIVIEN I RECURD I & $\begin{array}{l}\text { 3. Project No. } \\
\text { FIF }\end{array}$ & $\begin{array}{l}\text { 4. Page } 7 \text { of } 10 \\
\end{array}$ \\
\hline
\end{tabular}

\begin{tabular}{|c|c|c|c|c|}
\hline $\begin{array}{l}12 . \\
\text { Item }\end{array}$ & $\begin{array}{l}\text { 13. Comment(s)/Discrepancy(s) (Provide technical justification for the comment and } \\
\text { detailed recommendation of the action required to correct/ resolve the } \\
\text { discrepancy/problem indicated.) }\end{array}$ & $\begin{array}{l}14 . \\
\text { Hold } \\
\text { Point }\end{array}$ & 15. Disposition (Provide justification if NOT accepted.) & $\begin{array}{l}16 . \\
\text { Status }\end{array}$ \\
\hline 34 & $\begin{array}{l}\text { 7-1) The specifi ation requires the leak testing to be performed } \\
\text { on the completed shielded ISC. }\end{array}$ & & $\begin{array}{l}\text { Industry practice is consistent with GA's plans to } \\
\text { perform the leak testing of the confinement boundary } \\
\text { when the confinement boundary is completed. This } \\
\text { means that no more fabrication will be performed on } \\
\text { the confinement boundary. At this time, it can be } \\
\text { shown that the leakage requirements are not only met } \\
\text { for the closure seal, but also for the remainder of the } \\
\text { confinement system. }\end{array}$ & $\begin{array}{l}0 \\
*\end{array}$ \\
\hline 35 & $\begin{array}{l}\text { 8-1) The closure alignment pins are long. Has GA considered } \\
\text { the possibility of binding during remote installation of the } \\
\text { closure? }\end{array}$ & & $\begin{array}{l}\text { The alignment pins must be this long for them to } \\
\text { function correctly. The pins provide a } 0.12 \text {-in. radial } \\
\text { clearance with the closure's bolt hole ID during most } \\
\text { of the installation, which allows a tilt of } 1.8^{\circ} \text { before } \\
\text { binding could occur. The clearance reduces to } 0.06 \text {-in. } \\
\text { when the closure is } 0.5 \text {-in. above the flange, where } \\
\text { binding is no longer a serious concern. }\end{array}$ & \\
\hline
\end{tabular}

* 35) Ga will provide shorter alignment pins.

Sat.

* 34) GA will leak test cask after construction. (concrete) Sat. 


\begin{tabular}{|c|l|}
\hline $\begin{array}{c}\text { 1. Date } \\
8 / 22 / 94\end{array}$ & $\begin{array}{l}\text { Rev Reglew No. } \\
\text { Fnal }\end{array}$ \\
\hline $\begin{array}{c}\text { 3. Project Ho. } \\
\text { FIF }\end{array}$ & 4. Page 8 of 10 \\
\hline
\end{tabular}

12. 13. Comment(s)/Discrepancy(s) (Provide technical justification for the comment and 14

Item detailed recommendation of the action required to correct/ resolve the discrepancy/problem indicated.)

36 9-4) The environmental cover does not protect the lifting attachments from accumulation of dust, dirt, and moisture per section 3.2.2.1.10 of specification. The proposed ISC's environmental cover did.

\begin{tabular}{l}
\hline 4. \\
Hold \\
Point
\end{tabular}

15. Disposition (Provide justification if NOT accepted.)

16.

The attachment anchor tapped holes are filled with lubricated cover bolts, preventing dust, dirt and moisture from entering them. In addition, the tops and exposed sides of the anchors are galvanized and painted. The anchors are fully protected from the environment, certainly at least as protected as they were in the proposed ISC concept. The proposed design is better than putting the gasket outboard of the bolts. The outboard gasket design would require that some method be used to seal the hole around the cover bolts. If for some reason, water were to leak through these holes, then moisture would be trapped inside the cover. In the present design, water is prevented from being trapped inside the cover. In the present design, the only exposed surface is the concrete, which will not degrade in the presence of dust, dirt or moisture. As specified in 3.2.2.1.10, the concrete surface is sloped to minimize accumulation of dust, dirt, and moisture.

9-6) Notes 30 and 36 appear to conflict. Some tack welds of parts $38 / 39$ require, preheat while others do not.

Parts not identified by manufacturer are either raw materials or non-safety related equipment that can be sourced by the fabricator.

The first sentence of note 30 will be deleted to eliminate the weld size conflict. Pre-heat is only required for welds to the confinement boundary; notes will be modified to clarify this requirement.

A view of the ducts from the bottom is just a mirror image of the ducts as seen from above. There is no 
WHC-SD-FF-DRR-00018

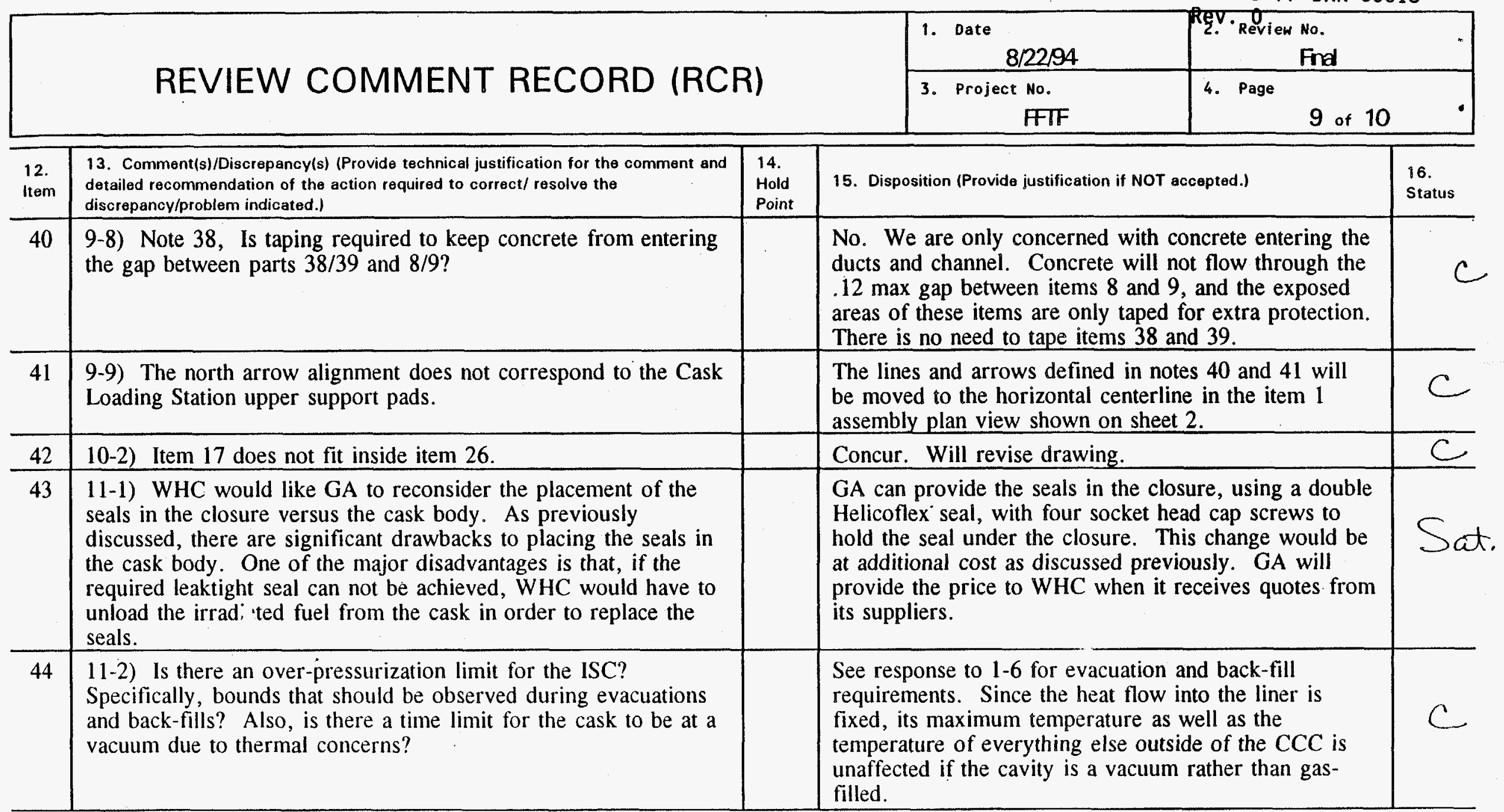




\section{REVIEW COMMENT RECORD (RCR)}

\begin{tabular}{|c|c|}
\hline $\begin{array}{c}\text { 1. Date } \\
8 / 2294\end{array}$ & $\begin{array}{c}\text { RęV. Rgview No. } \\
\text { Find }\end{array}$ \\
\hline $\begin{array}{c}\text { 3. Project No. } \\
\text { FTF }\end{array}$ & 4. Page 10 of 10 \\
\hline
\end{tabular}

\begin{tabular}{|c|c|c|c|c|}
\hline $\begin{array}{l}12 . \\
\text { Item }\end{array}$ & $\begin{array}{l}\text { 13. Comment(s)/Discrepancy(s) (Provide technical justification for the comment and } \\
\text { detailed recommendation of the action required to correct/ resolve the } \\
\text { discrepancy/problem indicated.) }\end{array}$ & $\begin{array}{l}14 . \\
\text { Hold } \\
\text { Point }\end{array}$ & 15. Disposition (Provide justification if NOT accepted.) & $\begin{array}{l}16 . \\
\text { Status }\end{array}$ \\
\hline 45 & $\begin{array}{l}\text { 12-1) An information sketch is provided that shows the desired } \\
\text { cask configuration on the storage pad. Is the ISC thermally } \\
\text { limited to the } 5.5 \text { foot minimum spacing or is this configuration } \\
\text { feasible? }\end{array}$ & & $\begin{array}{l}\text { We calculate that the proposed configuration will } \\
\text { increase temperatures by approximately } 5-10^{\circ} \mathrm{F} \text {. This } \\
\text { is due partly to the restricted radiant heat transfer to } \\
\text { the sky and partly to the increase in ambient } \\
\text { temperature at the interior of the array. While the } \\
\text { configuration is feasible in that temperatures would still } \\
\text { be below allowable limits, we do not recommend it } \\
\text { since margins are decreased. For example, in case } 2 \text {, } \\
\text { off-normal severe hot conditions, the overall average } \\
\text { concrete temperature could increase from } 135^{\circ} \text { to } \\
145^{\circ} \mathrm{F} \text {, decreasing the margin from } 15^{\circ} \text { to } 5^{\circ} \mathrm{F} \text {. }\end{array}$ & Sat. \\
\hline 46 & $\begin{array}{l}\text { 12-4) Closure Seal Test Port. WHC would like GA to consider } \\
\text { a standard, straight-thread O-ring fitting plug or quick-disconnect } \\
\text { in lieu of the teflon sealed } 1 / 4 \text {-inch NPT plug. }\end{array}$ & & $\begin{array}{l}\text { It is feasible to change this plug as desired. GA will } \\
\text { inform WHC of the added price if any after it receives } \\
\text { quotes from its suppliers. }\end{array}$ & \\
\hline & & & & \\
\hline & & & & \\
\hline & & & & \\
\hline & & & & \\
\hline
\end{tabular}

* GA will add to DAR. 
WHC-SD-FF-DRR-00018

\begin{tabular}{|c|c|c|}
\hline & $\begin{array}{l}\text { 1. Date } \\
7 / 26 / 94\end{array}$ & $\begin{array}{l}\text { Re. } \cdot \text { Review No. } \\
\text { Final }\end{array}$ \\
\hline REVIEW COMMENT RECORD (RCR) & $\begin{array}{l}\text { 3. Project No. } \\
\text { FFTF }\end{array}$ & $\begin{array}{l}\text { 4. Page } \\
1 \text { of } 4\end{array}$ \\
\hline
\end{tabular}

\section{Document Number(s)/Title(s)}

FFTF Spent Fuel Interim Storage Cask Design Analysis Report by General Atomics, June 1994

H-4-302134 ISC Out 1 ine/Interface System

H-4-302135 ISC Assembly H-4-302136 ISC Tiedown System

17. Comment Submittal Approval:

Organization Manager (Optional)

\begin{tabular}{|l|l|}
$\begin{array}{l}\text { 6. Program/Project/ } \\
\text { Building Number } \\
\text { FFTF/ISC }\end{array}$ & 7. Reviewer \\
R. B. Packard
\end{tabular}

8. Organization/Group
IEM Cell \& Refueling
Mechanical
Engineering

9. Location/phone

9. Location/Phone

N2-02/376-4219

Mechanical

Eng ineering

(n)

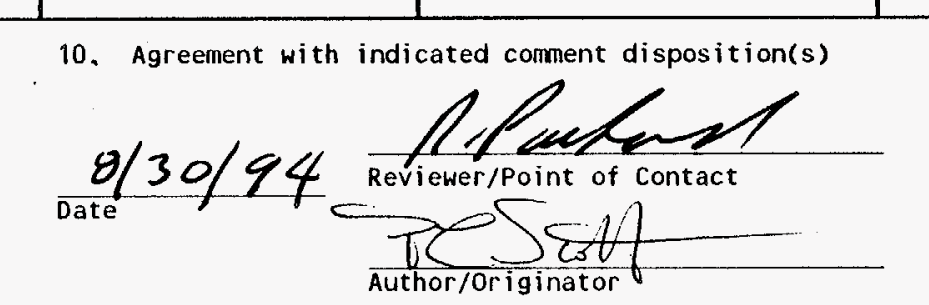

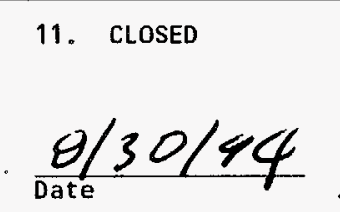

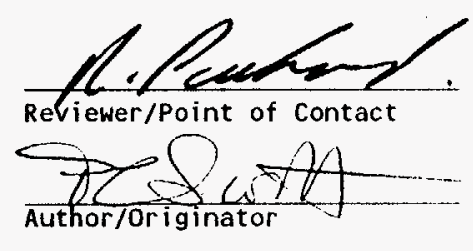
comment and detailed recommendation of the act
resolve the discrepancy/problem indicated.)

14.

Hoid Point
15. Disposition (Provide justification if NOT accepted.)

i 
WHC-SD-FF-DRR-00018

REVIEW COMMENT RECORD (RCR)

Reviretiew No.

\begin{tabular}{|c|l|}
\hline $\begin{array}{l}\text { 1. Date } \\
7 / 26 / 94\end{array}$ & $\begin{array}{r}\text { ReV }{ }_{\text {Reliew No. }}^{\text {Final }} \\
\hline \begin{array}{c}\text { 3. Project No. } \\
\text { FFTF }\end{array}\end{array}$ \\
\hline
\end{tabular}

1 9-1)The cask perpendicularity is controlled per note 38 to the O.D. of items 8 and 9 . How are items 8 and 9 controlled to the I.D. of the cask (item 5) so that the drawing requirement of the I.D. perpendicular to the base is assured? Will this be measured directly at final inspection?

so

To avoid the additional tolerance by taking measurements from the outside of items 8 and 9 , note 38 will be revised as follows;

With the cask in a vertical position, and prior to installing items 22,38 and 39 , the steel vendor shall hang three plumb lines $120^{\circ}$ apart from the top of the cask.

Permanently shim item 7 at two places $120^{\circ}$ apart such that the distance from item 5 , measured through the 2.0 square openings in items 8 and 9 , does not vary by more than .06 at each of the three locations. (First assure that the surface under item 7 is level within .015.) Datum $B$ is the plane at the bottom of the shims. The portion of each shim under item 7 shall be at least 10 $\mathrm{in}^{2}$.

The measurement and shim adjustment will be made while access is still available to the 2.0-in. square holes, so inspection will be made during fabrication and not at final inspection.

WHC- These methods are still under development GA's subcontractor. Therefore, final tolerance review is deferred to fabrication plan approval.

2 9-2) How is the 0.0 . of the cask controlled to the WHC- Final tolerance review is deferred to I.D.? How will final inspection be performed? fabrication plan approval. 


\begin{tabular}{|l|l|l|l|}
\hline \multirow{2}{*}{ REVIEW COMMENT RECORD (RCR) } & $\begin{array}{l}\text { 1. Date } \\
7 / 26 / 94\end{array}$ & $\begin{array}{l}\text { Re. Refiew No. } \\
\text { Final }\end{array}$ & $\begin{array}{l}\text { 3. Project No. Page } \\
\text { FFTF }\end{array}$ \\
\cline { 2 - 4 }
\end{tabular}

3 9-3) Per note 38 the shims under item 7 establish datum B. Therefore, is the hole in item 7, which per the drawing is located to datum $B$, drilled after shimming? Also, how is this hole located to the I.D. of the cask (datum A)? How will final inspection be performed?

12-2) An information sketch is also provided that shows the discussed cask alignment feature. WHC realizes that there may be constraints in GA's design that WHC has not recognized and is open for further discussion of this feature.
The tolerance callout was intended to apply to the $\emptyset 1.5-6$ tapped hole, not the $\emptyset 1.562$ clearance hole; this will be corrected. Datum B will be deleted as a secondary datum.

How the tapped hole is located and inspected is up to the fabricator. However, the tapped hole will be hidden after installation of items 7 and 18 , so inspection of the hole's location must be performed prior to such installation.

WHC- These methods are still under development GA's subcontractor. Therefore, final tolerance review is deferred to fabrication plan approval.

GA can provide the alignment feature. This change will increase the dose rate on the bottom of the cask to approximately 100 $\mathrm{mrem} / \mathrm{h}$. If a drop onto the 6 -inch centering post is considered an accident, the load limit shall be less than that shown in Section $3 \cdot 5 \cdot 7.3 .3$ of the DAR during a puncture drop (1,330 kips). This change would be at additional cost as discussed previously. GA will. inform WHC of the added. price after it receives quotes from its suppliers.

WHC- GA will provide the alignment feature. 
WHC-SD-FF-DRR-00018

\begin{tabular}{|l|l|l|l|}
\hline \multirow{2}{*}{ REVIEW COMMENT RECORD (RCR) } & \begin{tabular}{l} 
1. Date \\
\cline { 2 - 3 }
\end{tabular} & $\begin{array}{l}7 / 26 / 94 \\
\text { 3. Project No. RQview No. } \\
\text { FFTF }\end{array}$ \\
\hline
\end{tabular}

5 12-3) WHC requested GA to consider a flatness of 5 mils on the ISC upper 0 -ring seal plate.

Even though the specification has no

criteria (pressure, allowable leakage, etc.) regarding the seal interface, GA has two

concerns with WHC's seal design. First, the WHC mating flange has an implied flatness of $.060 \mathrm{in}$. Thus, a flatness of $.005 \mathrm{in}$. for the GA mating surface will not ensure the surfaces are in close contact. Second, the Parker Handbook does not specify a flatness tolerance but relies instead on bolts to provide a uniform clamping force and contact between the mating surfaces. There is no uniform clamping force around the periphery in the WHC design.

Notwithstanding the above, it is feasible to change the design to provide an improved flatness on the upper 0 -ring seal plate.

Our supplier has recommended against a $5 \mathrm{mil}$ flatness tolerance but is investigating a 10 and $15 \mathrm{mil}$ flatness tulerance. GA will inform WHC of the added price after it receives quotes from its suppliers.

WHC - GA will provide a 5 mil flatness. 
WHC-SD-FF-DRR-00018

Rev. 0

\section{ATTACHMENT 7}

THERMAL ANALYSIS EVALUATION AND VERIFICATION ANALYSIS 


\section{DON'T SAY IT - - WRITE IT!}

To: P. L. Scott $(\mathrm{N} 2-02)$

cc: T. B. McCall

From: John Irwin

Date: July 26, 1994

HO-33 $376-0615$

\section{Subject: REVIEW OF GA INTERIM STORAGE CASK THERMAL ANALYSIS}

References: . GA, 1994, FFTF Spent Fuel Interim Storage Cask - Design Analysis Report, GA Report No. 910683/0, General Atomics Co., San Diego CA.

WHC, 1993, Thermal Analysis Methods for Safety Analysis Reports For Packaging, WHC-SD-TP-RPT-005, Westinghouse Hanford Co., Richland, Wa.

Based on GA report $910683 / 0$, I offer my comments to the General Atomics thermal hydraulic analysis concepts for the Interim Storage Cask (ISC).

\section{Summary}

GA performed an excellent thermal analysis for the proposed design of the ISC. Their modelling techniques, defined thermal boundary conditions and material thermal properties were all properly defined. GA did an exemplary analysis of the various normal and hypothetical accident conditions specified for the ISC. Where there were disagreements between this reviewer and the GA analysis, GA's assumptions were on the conservative side.

\section{Specific Comments}

Material Properties:

The thermophysical material properties were conservatively defined by GA in their repont. The tabulated properties for carbon steel, concrete, air and argon were reviewed against WHC 1993 and there was good agreement. The properties (thermal conductivity) listed by GA for volcanic ash were an order of magnitude lower than those 1 isted in WHC 1993. A lower conductivity is conservative. The properties for the aluminum honeycomb could not be verified but this material has a negligible influence on the thermal response of the ISC. The solar absorptivity and thermal emissivity for the painted concrete surface were also conservatively stated. The CCC/DFA effective thermal conductivities were reasonably defined (the GA stated conductivity for the FFTF DFA is within $15 \%$ of the values "sed by this reviewer).

Thermal Boundary Conditions:

The external and internal convection coefficients were reasonably determined for both the forced flow and natural convection conditions. The convection correlations utilized by GA were verified against WHC 1993 and 
WHC-SD-FF-DRR-00018

Rev. 0

other published reports. The techniques used are those that are commonily accepted for safety analysis of shipping casks. The only area of disagreement was that the convection correlation used for the center tube of the CCC is for horizontal cylinders. A vertical enclosed cylinder correlation should have been utilized, the impact on the predicted thermal response of the ISC is negligible.

\section{Heat Generation:}

The internal heat generation due to decay heat within the DFA's was properly calculated. The specified decay heat of 250 Watts per DFA and 1500 Watts total were utilized. For the $r-z$ thermal models (longitudinal axisymmetric), the decay heat was modelled as a volumetric heat source uniform over a $3 \mathrm{ft}$. Tength of the DFA centered at the fueled region of the DFA. This is proper and per the design specification. For the r-theta (plain slice) models the decay heat was modelled as a uniform heat flux to the inside surface of the ISC Iiner. This was also proper and utilized a heat flux calculated from the design specification.

\section{Thermal Radiation:}

The thermal radiation view factors were properly calculated utilizing standard methods from heat transfer text books. The thermal emissivity values were conservatively estimated for painted steel and concrete and for the stainless steel surfaces of the DFA's and CCC.

\section{Solar Heating:}

The GA analysis utilized the solar insolation values as provided by the design specification. The solar absorptivity of the painted concrete surface of the ISC was conservatively estimated. The solar insolation averaging techniques utilized by GA were proper for the steady state analyses as for determining the thermal response of the interior portions of the ISC. GA performed a transient analysis that modelled the diurnal solar insolation and ambient temperature. This latter analysis used the $r$-theta model of the ISC.

Ambient Temperature:

The ambient temperatures were applied properly as per the design specification.

\section{Contact Resistance:}

The thermal contact resistance between the ISC and the concrete pad was modelled in a conservative manner. The heat loss to the concrete pad will have a negligible influence on the thermal response of the ISC. 


\section{Advection:}

Advection pertains to the air flow through the ISC annulus. This boundary condition could not be directly verified by this reviewer. Prior thermal analyses of preliminary ISC designs using GA defined boundary conditions but utilizing WHC finite element based software has shown good agreement with $G A$ results. An independent finite element based analysis of the Final ISC design will be completed shortly. The current GA results appear. to be reasonable.

\section{Flow Coefficients:}

The flow coefficients used to calculate the air flow rate through the ISC annulus were determined properly by GA. This reviewer utilized standard references in performing an independent assessment of GA's methods. The actual flow rate of air through the ISC should be measured during acceptance testing and correlated with cask temperatures also recorded during the test. The measured air flow rate can then be used in a final assessment of the thermal response of the ISC.

Geometry Used in Thermal Model:

The thermal model geometry matched dimensions listed on the drawings contained in the design analys is report. GA did not model every nut and bolt in the ISC design but had sufficient detail to adequately model the proposed ISC design. The modelling of the various air gaps within the ISC was conservative.

\section{Mode11ing Techniques - Events:}

Normal conditions of storage (Steady State) with site specific maximum solar insolation and ambient temperatures were modelled. The events included a site specific average wind condition as well as a no wind condition. This latter event meet the 10CFR71 requirements for normal conditions.

A normal condition event with diurnal solar and ambient temperature transients was also modelled. Both longitudinal and circumferential models were used. The solar transient has no effect on the interior of the cask. There are temperature fluctuations in the outer regions of the cask that could not be determined by the steady state case. These results should be used in the structural assessments of the cask. The temperature fluctuations are of a minor magnitude.

The hypothetical accident condition assuming a $1475^{\circ} \mathrm{F}$ fire, lasting 30 minutes was properly performed in accordance with the 10CFR71 requirements. The emissivity used for the fire event was conservatively applied. GA used an emissivity of 0.9 versus 0.8 from 10CFR71. GA also properly applied an thermal energy term for the ISC's paint combustion resulting from the hypothetical firs event. 
The hypothetical accident condition assuming an volcanic ashfall was conservatively performed. GA's assumed a conservative value for the thermat conductivity of the ash. GA's analysis also assumed blockage of the ventilation ducts.

The modelling of the above events resolves all comments pertaining to design events that this reviewer documented during the preliminary design review of the ISC.

Modelling Techniques - Application:

The mesh sizing utilized by GA in the thermal models was conservatively applied. Thermal modelling techniques were properly utilized to model all of the important physical phenomena associated with the ISC at its final storage site. I could find no oversights.

Verification/Validation of Software:

The verification/validation of the software used by GA has been previously reviewed by this reviewer. GA's thermal analysis was within the capabilities of the software.

Temperature Predictions:

The temperature predictions for the ISC for the various events appear to be reasonable and consistent. The temperature predictions are similar to results of the preliminary analys is that have been independently verified by this reviewer. 
WHC-SD-FF-DRR-00018

Rev. 0

Westinghouse

Internal Hanford Company

Memo

From: $\quad$ Thermal Hydraulic Analysis

7E870-JJI -94-059

Phone: $\quad 376-0615$ HO-33

Date: June 24, 1994

Subject: THERMAL ANALYSIS OF VENTILATED INTERIM STORAGE CASK

To:

P. L. Scott

$\mathrm{N} 2-02$

cc:

J. L. Marshall

$\mathrm{N} 2-02$

T. B. McCal1

$\mathrm{HO}-33$

JJI File/LB

REFERENCES: 1) GA, 1993, FFTF Spent Fuel Interim Storage Cask

Preliminary Design Analysis Report, December 1993, General Atomics, San Diego, California.

2) WHC, 1993, Environmental Conditions for On-Site Hazardous Material Packages, WHC-SD-TP-RPT-004, Rev. 0, Westinghouse Hanford Company, Richland, Washington.

3) WHC, 1994, Thermal Analysis Methods for Safety Analysis Reports for Packaging, WHC-SD-TP-RPT-005, Rev. 0 , Westinghouse Hanford Company, Richland, Washington.

4) PATRAN 1991, P/THERMAL User Manua7, Release 2.5, PDA Engineering, Costa Mesa, Cal ifornia.

5) PNL, 1992, Performance Testing and Analyses of the VSC17 Ventilated Concrete Cask, PNL-7839, Pacific Northwest Laboratories, Richland, Washington.

6) WHC, 1994, THERMAL ANALYSIS OF NON-VENTILATED INTERIM STORAGE CASK, Internal Memo 7E870-JJI-94-054, Westinghouse Hanford Company, Richland, Washington.

\section{PURPOSE}

A thermal analysis of the ventilated Interim Storage Cask (ISC) was performed. The non-ventilated ISC is described in reference 1 . The analysis.assumed that 1500 Watts of decay heat from six FFTF driver fuel assemblies (DFAs) were in the cask. Normal conditions of storage (ie., nonaccident conditions) were also assumed. The normal conditions assumed the peak solar and ambient temperature conditions as defined in reference 2 for the Hanford site. The ventilated ISC, as proposed in reference 1 , is depicted in Figure 1.

The purpose of this work was to verify the maximum temperatures of the cask structural and shielding materials for the proposed cask design. A comparison was also made to the non-ventilated cask design. 
WHC-SD-FF-DRR-00018

Rev. 0

P. L. Scott

7E870-JJI-94-059

Page 2

June 24, 1994

\section{THERMAL MODEL}

The thermal model of the ISC is shown in Figure 2. This figure depicts the ISC with the applied thermal boundary conditions as specified by GA in reference 1 . The cask was modelled as a 20 axisymmetric surface of revolution with uniform boundary conditions at the top and around the circumference of the cask vertical side.

Four cases were performed to verify the GA thermal analysis. Case 1 consisted of repeating the GA analysis based upon the reference 1 configuration, material properties, thermal boundary conditions and performing a steady state analysis. Case 2 is a repeat of the steady state case with the same configuration but with revised material properties and thermal boundary conditions as specified in reference 3 . Case 3 was run to determine the effect of increased heat loss from the cask by thermal radiation from the cask side. A view factor of 0.15 was used, whereas GA utilized a zero view factor per reference 1 . Case 4 is a repeat of Case 2 but with the ventilation ducts blocked.

For the steady state thermal analyses, the solar insolation was determined as a 24 hour average of the peak Hanford site insolation (for the month of July). The solar absorptivity of the ISC was specified in reference 1 as 0.3 with a thermal emissivity of 0.9 . These values are acceptable and similar values for white paint are tabulated in reference 3 . The thermal emissivity for unpainted carbon steel was 1 isted at 0.8 in reference 1 and this value was used for all cases.

The ambient temperature of $94^{\circ} \mathrm{F}$ was specified in reference 1 for the 24 hour average of the peak Hanford site ambient temperature. This value is within $0.5^{\circ} \mathrm{F}$ of the average specified in reference 2 and therefore is acceptable. The above-average insolation and ambient temperature were used for a 11 cases. 
Page 3

June 24,1994

Figure 1. Ventilated ISC.

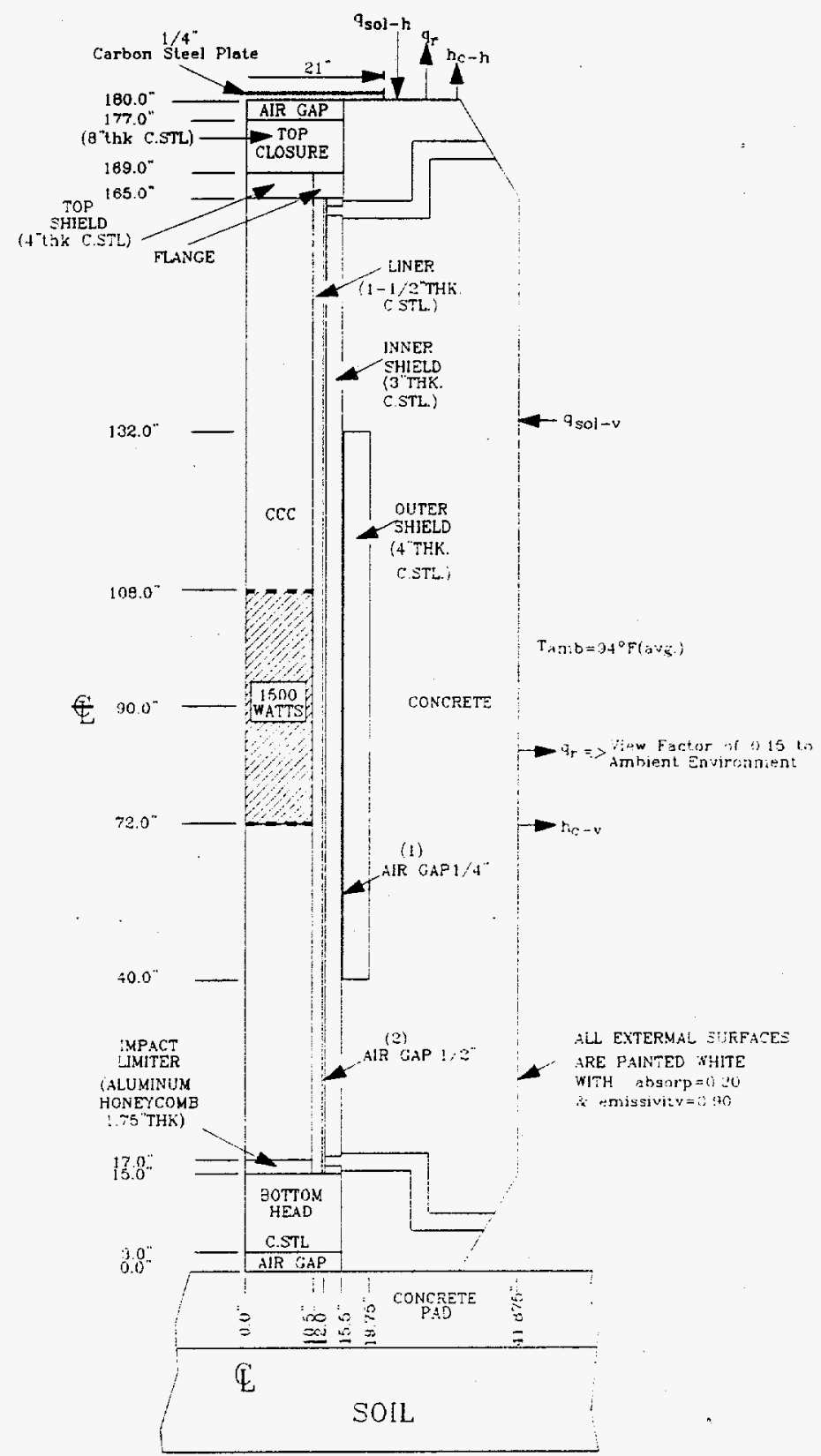

(1) Gas Gap With air Conduction \& Thermal Radiation Heat Transfer $\in 0.81$

(2) Gas Gap With Advection \& Thermal Radiation Heat Transfer if 0 gi 
P. L. Scott

Page 4

June 24,1994

\section{Figure 2. Ventilated ISC Thermal Model.}

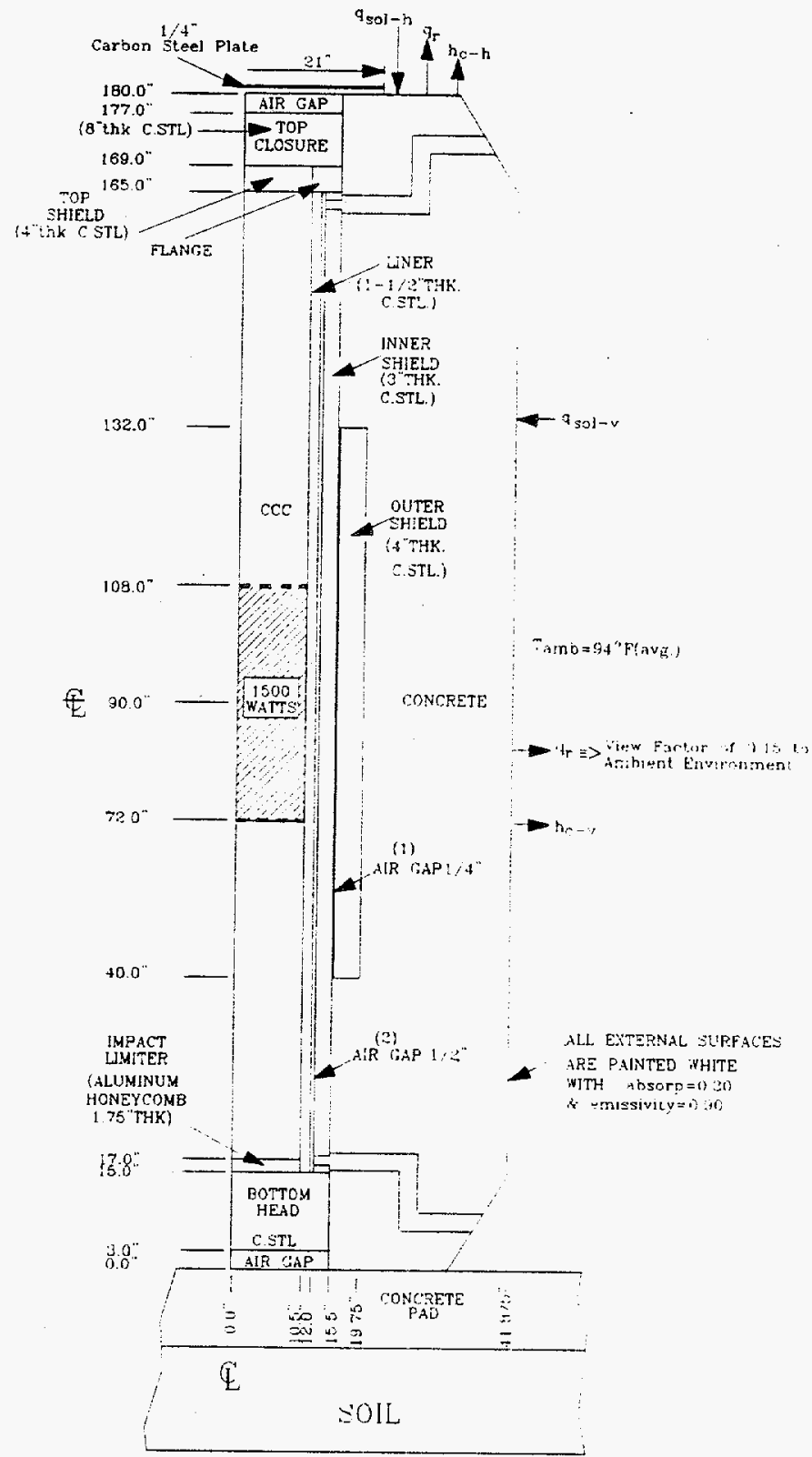

(1) Gas Gap With Air Conduction \& Thermai Radiation Heat Fransfer (e of 4 )

(2) Gas Gap With Advection \& Thermal Faciation Heat Pransfer $(E ⿰ 冫)$ 
WHC-SD-FF-DRR-00018

Rev. 0

P. L. Scott

7E870-JJI-94-059

Page 5

June 24,1994

The GA model assumed an $8 \mathrm{mph}$ wind speed which results in an enhanced thermal heat rejection from the cask by thermal convection. For case 1 the convection coefficients specified by GA were used. For cases 2, 3 and 4 , a zero wind speed was assumed resulting in convection coefficients that are approximately $50 \%$ of the GA values.

The material thermal properties specified by GA were used in case 1 and are given in Table 1. These included constant thermal conductivities for concrete, carbon steel, aluminum honeycomb and the smeared mass Core Component Container model with six DFAs installed. GA used variable conductivities for air. The thermal emissivity for carbon steel was specified as 0.8 . For cases 2,3 and 4 , thermal. conductivities as a function of temperature were used as shown in Table 2. The thermal property values for the CCC and DFAs were the same for all cases.

The cask thermal model assumed an adiabatic condition on its lower surface, that is, no heat loss from the cask to the concrete pad, which is conservative. No thermal radiation heat loss from the side of the cask was assumed for cases 1, 2 and 4, while a thermal radiation heat loss from the top of the cask was assumed for all cases. The assumption of no thermal radiation heat loss for the cask side is probably overly conservative as thermal radiation heat loss at the predicted temperatures is about twice that of heat loss by natural convection. Therefore, case 3 was performed to evaluate this effect. A thermal radiation view factor of 0.15 was used for this case, this factor represents the fraction of energy lost to the environment from the cask side. This view factor was specified in reference 1 , the actual view factor depends on the final cask siting arrangement. The larger the spacing between cask, the larger will this factor be.

Cases 1,2 and 3 utilized the GA determined air flow rate through the cask ventilation ducts. This flow rate was specified in reference 1 as $501 \mathrm{~b}$ per hour with an internal flow velocity of $1 \mathrm{ft}$ per sec. The air flow was modelled as an advection term in the thermal model. The thermal model also utilized the GA internal heat convection value for the annular ventilation gap which was specified as $1.5 \mathrm{Btu} / \mathrm{hr}$-sq. $\mathrm{ft}-{ }^{\circ} \mathrm{F}$. This value is reasonable for the specified air flow velocity and flow configuration. Case 4 had the advection flow turned off to model the case where the ventilation intake or exhaust ducts are blocked for any reason.

The Patran and P/THERMAL finite element computer programs (Reference 4) were utilized to create and analyze the thermal model of the ISC. Version 3.0 of Patran and version 2.6 of P/THERMAL were used for this analysis. 
WHC-SD-FF-DRR-00018

Rev。 0

P. L. Scott

7E870-JJI-94-059

Page 6

June 24, 1994

Table 1a. Material Properties for ISC Thermal Analysis (GA 1993).

\begin{tabular}{|c|c|c|c|c|}
\hline Material & $\begin{array}{c}\text { Thermal } \\
\text { Conductivity } \\
\left.\text { (BTU/Hr-Ft- }{ }^{\circ} \mathrm{F}\right)\end{array}$ & $\begin{array}{c}\text { Specific } \\
\text { Heat } \\
\left.\text { (BTU/Lbm- }{ }^{\circ} \mathrm{F}\right)\end{array}$ & $\begin{array}{c}\text { Density } \\
\left(1 \mathrm{~b} / \mathrm{ft}^{3}\right)\end{array}$ & Emissivity \\
\hline \hline Carbon Steel & 25 & 0.11 & 490 & 0.8 \\
\hline Concrete & 1.0 & 0.156 & 146 & 0.9 \\
\hline Air & Table 1b. & Table 1b. & Table 1b. & NA \\
\hline Al Hcomb. & $0.64 / 4.8^{(1)}$ & NA & 11.5 & 0.5 \\
\hline CCC/DFA & $0.5 / 3.35^{(1)}$ & 0.090 & 169.7 & NA \\
\hline
\end{tabular}

1) Radial/Axial thermal Conductivity.

Table 1b. Material Properties of Air at 1 atm.

\begin{tabular}{|c|c|c|c|}
\hline $\begin{array}{c}\text { Temperature } \\
\left({ }^{\circ} \mathrm{F}\right)\end{array}$ & $\begin{array}{c}\text { Thermal } \\
\text { Conductivity } \\
\left.\text { (BTU/Hr-Ft- }{ }^{\circ} \mathrm{F}\right)\end{array}$ & $\begin{array}{c}\text { Thermal } \\
\text { Conductivity } \\
\text { (BTU/Sec-Inch- } \\
{ }^{\circ} \mathrm{F} \text { ) }\end{array}$ & $\begin{array}{c}\text { Specific } \\
\text { Heat } \\
\text { (BTU/Lbm- }{ }^{\circ} \mathrm{F} \text { ) }\end{array}$ \\
\hline-110 & 0.0118 & 0.000000273 & 0.2393 \\
\hline 40 & 0.0143 & 0.000000331 & 0.2396 \\
\hline 90 & 0.0156 & 0.000000361 & 0.2399 \\
\hline 240 & 0.0191 & 0.000000442 & 0.2416 \\
\hline 440 & 0.0237 & 0.000000549 & 0.2458 \\
\hline 640 & 0.0280 & 0.000000648 & 0.2516 \\
\hline 840 & 0.0320 & 0.000000741 & 0.2579 \\
\hline 1040 & 0.0370 & 0.000000856 & 0.2642 \\
\hline 1240 & 0.0022 & 0.000000049 & 0.2698 \\
\hline 1440 & 0.0450 & 0.000001042 & 0.2750 \\
\hline 1640 & 0.0480 & 0.000001111 & 0.2704 \\
\hline
\end{tabular}

Density of $0.000047\left(1 \mathrm{bm} / \mathrm{in}^{3}\right), 0.0812(1 \mathrm{bm} / \mathrm{cu}$. ft.) at STP. 
WHC-SD-FF-DRR-00018

Rev. 0

P. L. Scott

7E870-JJI-94-059

Page 7

June 24, 1994

Table 2a. Material Properties of Mild Carbon Steel.

\begin{tabular}{|c|c|c|c|}
\hline $\begin{array}{c}\text { Temperature } \\
\left({ }^{\circ} \mathrm{F}\right)\end{array}$ & $\begin{array}{c}\text { Thermal } \\
\text { Conductivity } \\
\left(\mathrm{BTU} / \mathrm{Hr}-\mathrm{Ft}-{ }^{\circ} \mathrm{F}\right)\end{array}$ & $\begin{array}{c}\text { Thermal } \\
\text { Conductivity } \\
\text { (BTU/Sec-Inch- } \\
{ }^{\circ} \mathrm{F} \text { ) }\end{array}$ & $\begin{array}{c}\text { Specific } \\
\text { Heat } \\
\left(\mathrm{BTU} / \mathrm{Lbm}-{ }^{\circ} \mathrm{F}\right)\end{array}$ \\
\hline-100 & 24.91 & 0.0005767 & 0.120 \\
\hline 0 & 24.91 & 0.0005767 & 0.120 \\
\hline 399 & 24.43 & 0.0005655 & 0.124 \\
\hline 800 & 22.33 & 0.0005168 & 0.148 \\
\hline 1198 & 18.62 & 0.0004311 & 0.180 \\
\hline 1450 & 14.99 & 0.0003471 & 0.200 \\
\hline 1600 & 15.60 & 0.0003611 & 0.140 \\
\hline
\end{tabular}

Density of $0.284\left(1 \mathrm{bm} / \mathrm{in}^{3}\right), 490(\mathrm{lbm} / \mathrm{cu} . \mathrm{ft})$.

Table 2b. Material Properties of Concrete (PNL- 7839).

\begin{tabular}{|c|c|c|c|}
\hline $\begin{array}{c}\text { Temperature } \\
\left({ }^{\circ} \mathrm{F}\right)\end{array}$ & $\begin{array}{c}\text { Thermal } \\
\text { Conductivity }^{(1)} \\
\left(\mathrm{BTU} / \mathrm{Hr}-\mathrm{Ft}^{\circ}{ }^{\circ} \mathrm{F}\right)\end{array}$ & $\begin{array}{c}\text { Thermal } \\
\text { Conductivity }\end{array}$ & $\begin{array}{c}\text { Specific } \\
\text { Heat } \\
\left(\mathrm{BTU} / \mathrm{Sec}-{ }^{(2)}\right. \\
\left.{ }^{\circ} \mathrm{F}\right)\end{array}$ \\
\hline \hline 86 & 1.15 & 0.00002662 & 0.20 \\
\hline 149 & 1.11 & 0.00002569 & 0.20 \\
\hline 212 & 1.07 & 0.00002477 & 0.20 \\
\hline 302 & 1.02 & 0.00002361 & 0.20 \\
\hline 392 & 0.96 & 0.00002222 & 0.20 \\
\hline 482 & 0.91 & 0.00002106 & 0.20 \\
\hline
\end{tabular}

Density of $0.085\left(1 \mathrm{bm} / \mathrm{in}^{3}\right), 145.3(1 \mathrm{bm} / \mathrm{cu} . \mathrm{ft})$.

1) After Conditioning at $257^{\circ} \mathrm{F}$ for 48 hours.

2) Data from WHC 1994. 
Page 8

June 24,1994

\section{RESULTS}

This conservative analysis showed that the ISC with up to 1500 Watts of heat generation from six DFAs will reach a maximum temperature of $446^{\circ} \mathrm{F}$ in the center of the cask for the worst case normal storage assumptions, Case 1. Figure 3 is a fringe plot of the ISC temperatures for Case 1 . Figures 4, 5, and 6 provide the fringe plots of the temperature results for Cases 2,3 , and 4 , respectively.

Table 3 lists the maximum temperatures at discrete points through the cask at a horizontal plane coinciding with the fuel midplane. The results from reference 1 are also included for comparison. A plot of results from the General Atomics analysis (reference 1) and for Case 1, 2, 3, and 4 is depicted in Figure 7 .

Table 3. Ventilated Cask Thermal Analysis Results

\begin{tabular}{|c|c|c|c|c|c|c|}
\hline Location & $\begin{array}{l}\text { Radial } \\
\text { Dist., } \\
\text { Inches }\end{array}$ & Case $1^{(1)}$ & $\begin{array}{l}\text { Maximum } \\
\text { Case } 9(2) \\
\end{array}$ & $\begin{array}{l}\text { ady State } \\
\text { Case } 2^{(2)}\end{array}$ & $\begin{array}{l}\text { eratures, }{ }^{\circ} \mathrm{F} \\
\text { Case } 3^{(2)}\end{array}$ & Case $4^{(2)}$ \\
\hline CCC/Fuel-center & 0.0 & NA & 428 & 446 & 440 & 502 \\
\hline CCC/Fuel-mid & 3.5 & NA & 399 & 418 & 412 & 474 \\
\hline Ccc/Fuel-outer & 7.0 & NA & 329 & 348 & 342 & 407 \\
\hline CCC/Liner & 10.5 & 242 & 208 & 226 & 220 & 289 \\
\hline Liner-outside & 12.0 & 241 & 207 & 225 & 219 & 288 \\
\hline Inner Shld-inside & 12.5 & 184 & 187 & 206 & 200 & 220 \\
\hline Inner Shld-outside & 15.5 & 182 & 186 & 205 & 199 & 219 \\
\hline Outer Shld-inside & 15.75 & 158 & 153 & 175 & 168 & 188 \\
\hline Outer Shld/Conc & 19.75 & 157 & 152 & 174 & 167 & 187 \\
\hline Concrete-inner & 23.86 & 148 & 142 & 165 & 158 & 177 \\
\hline Concrete & 27.79 & 138 & 134 & 158 & 150 & 168 \\
\hline Concrete-mid & 31.55 & 130 & 127 & 152 & 144 & 161 \\
\hline Concrete & 35.15 & 124 & 121 & 147 & 139 & 155 \\
\hline Concrete & 38.59 & 119 & 117 & 143 & 135 & 150 \\
\hline Concrete-outside & 41.875 & 115 & 113 & 140 & 131 & 146 \\
\hline
\end{tabular}

1) Analys is by GA, reference 1

2) Analys is by WHC;

a Case 1 utilized GA'S Thermal Boundary Conditions

- Case 2 utilized WHC recommended Thermal Boundary Conditions

- Case 3 utilized thermal radiation from the cask side,

view factor of 0.15

- Case 4 utilized blocked ventilation ducts. 
WHiC-SD-FF-DRR-00018

Rev. 0

P. L. Scott

7E870-JJI-94-059

Page 9 .

June 24,1994

Figure 3. Ventilated ISC Temperature Fringe Plot, Case 1.

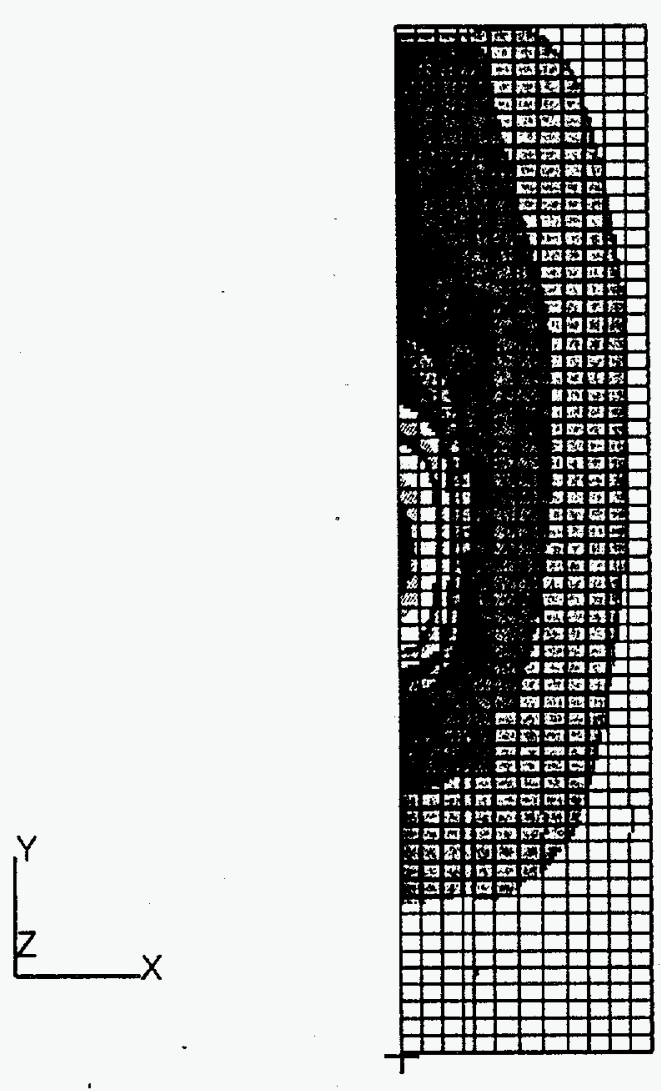

427.7

405.4

383.2

360.9

338.7

316.4

294.2

272.0

249.7

227.5

205.2

183.0

160.7

138.5

116.2

94.00 
WHC-SD-FF-DRR-00018

Rev. 0

P. L. Scott

7E870-JJI-94-059

Page 10

June 24,1994

Figure 4. Ventilated ISC Temperature Fringe Plot, Case 2.

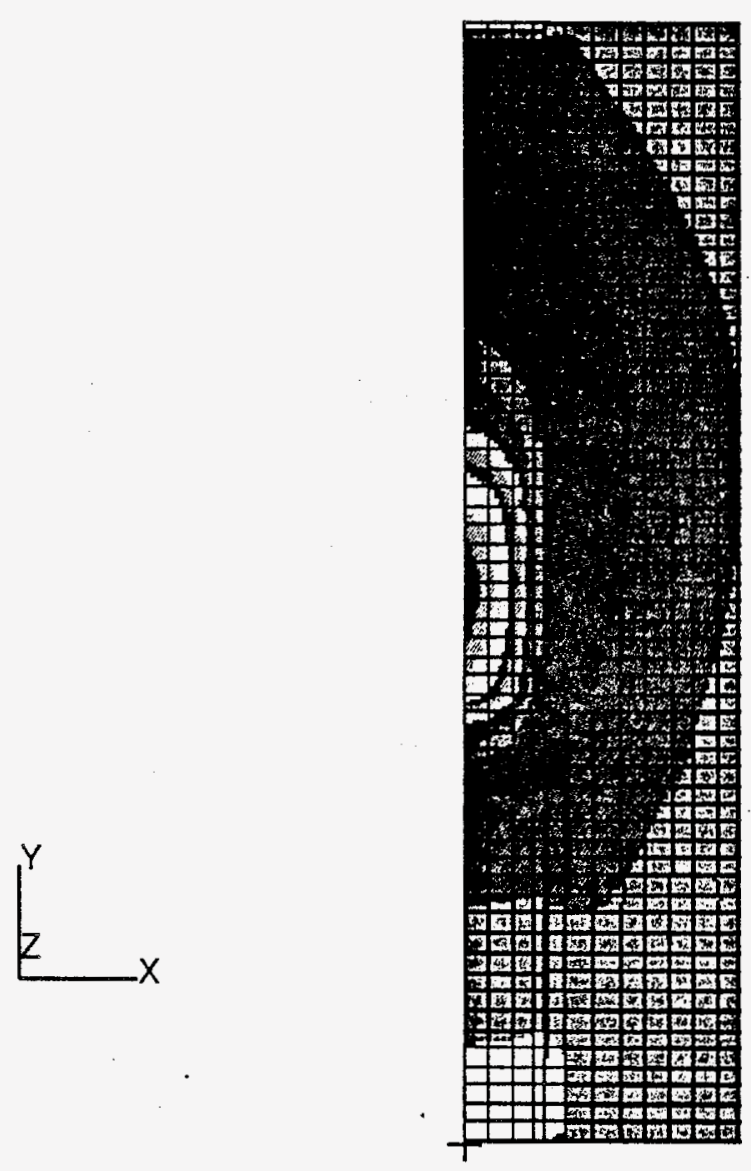

446.1

422.7

399.2

375.7

352.2

328.8

305.3

281.8

258.3

234.9

211.4

187.9

164.4

141.0

117.5

94.00

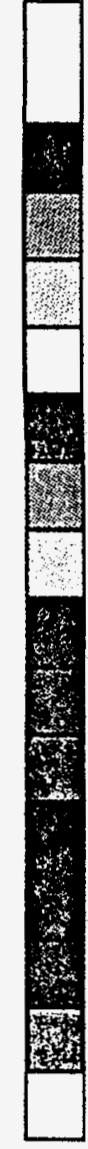

A $7-15$ 
WHC-SD-FF-DRR-00018

Rev. 0

P. L. Scott

7E870-JJ1-94-059

Page 11

June 24, 1994

Figure 5. Ventilated ISC Temperature Fringe Plot, Case 3.

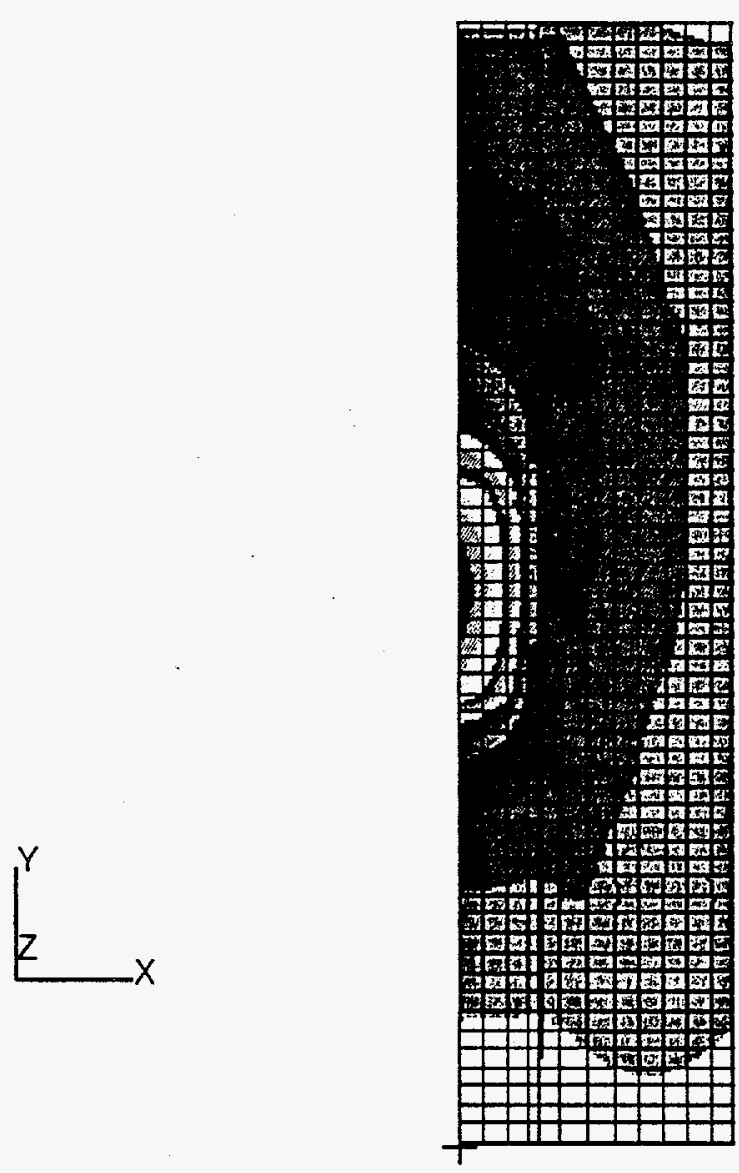

440.3

417.2

394.1

371.0

348.0

324.9

301.8

278.7

255.6

232.5

209.4

186.3

163.3

140.2

117.1

94.00

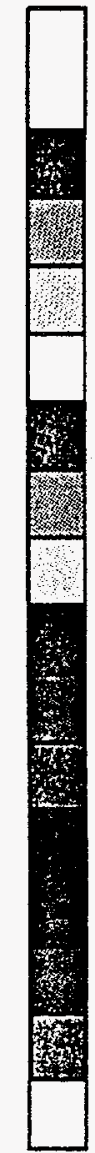

A $7-16$ 
WHC-SD-FF-DRR-00018

Rev. 0

P. L. Scott

Page 12

7E870-JJI-94-059

June 24,1994

Figure 6. Ventilated ISC Temperature Fringe Plot, Case 4.

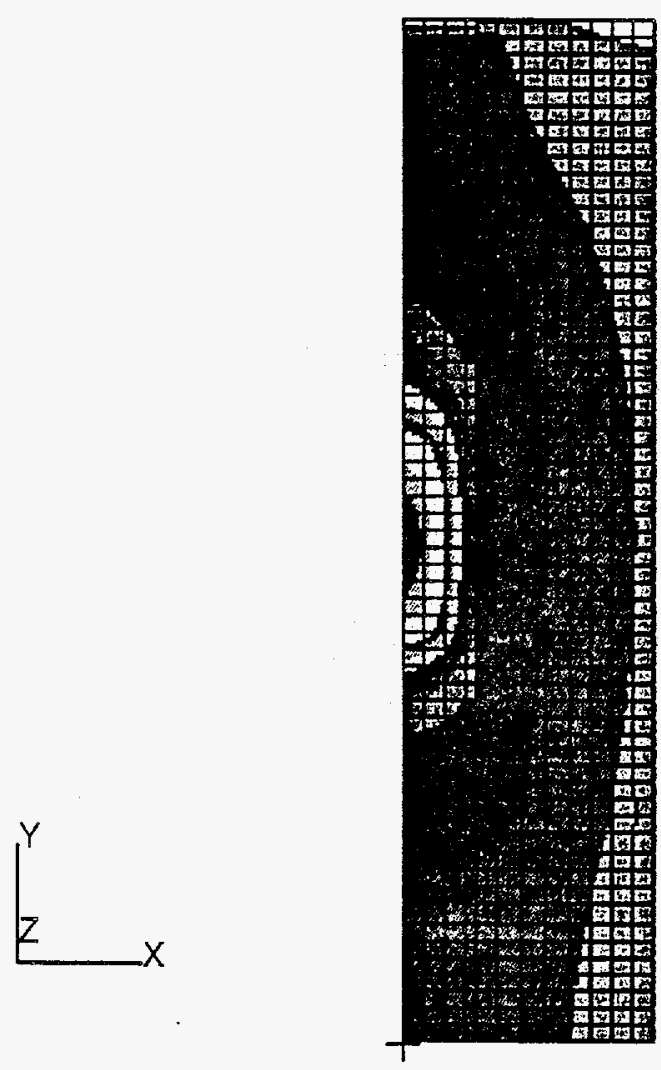

502.9

475.6

448.4

421.1

393.9

366.6

339.3

312.1

284.8

257.6

230.3

203.0

175.8

148.5

121.3

94.00

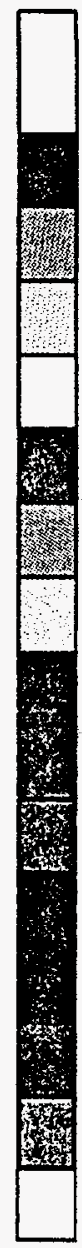

A7-17 
WHC-SD-FF-DRR-00018

Rev. 0

P. L. Scott

7E870-JJI-94-059

Page 13

June 24, 1994

Figure 7. Ventilated ISC Temperature PTot Comparison.

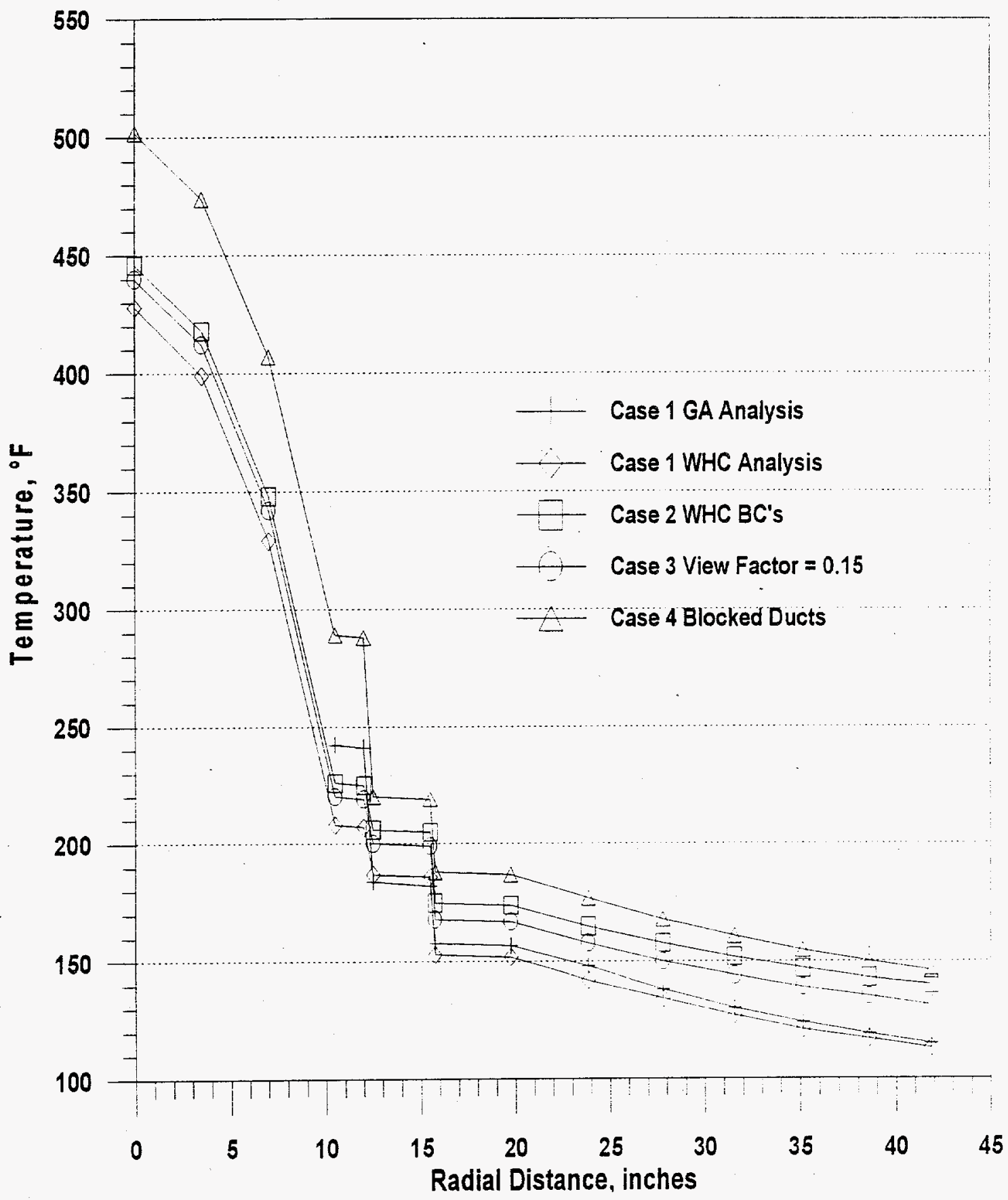

$A 7-18$ 
WHC-SD-FF-DRR-00018

Rev. 0

P. L. Scott

7E870-JJI-94-059

Page 14

June 24,1994

\section{DISCUSSION}

From Figure 7 and Table 3 it can be seen that the GA ISC temperatures from Reference 1 match very closely those predicted by this author in Case 1 . However, there is a discrepancy for the temperatures within the CCC region. As noted above, Case 1 used the same configuration, material properties, boundary conditions and modelling techniques as reference 1 . The temperatures from Case 2 are approximately 20 to $25^{\circ} \mathrm{F}$ higher than Case 1 or the GA analysis. This is attributable entirely to the assumed natural convection boundary condition where no external wind was assumed. GA assumed an $8 \mathrm{mph}$ wind speed.

Case 3 determined the effect of allowing heat rejection from the side of the cask by thermal radiation. Assuming a view factor of 0.15 reduced the internal cask temperatures by $6^{\circ} \mathrm{F}$ and the outer cask temperatures were reduced by $9^{\circ} \mathrm{F}$. Larger viewfactors will allow for more heat rejection and thus lower temperature distributions in the cask. The viewfactors are dependent on cask siting arrangements.

Case 4 determined the effect of isolating the ISC internal ventilation. Total blockage of the ventilation ducts will increase the temperatures by approximately $56^{\circ} \mathrm{F}$ at the center and $6^{\circ} \mathrm{F}$ at the exterior surface. This case is an off normal situation.

In all normal cases the maximum concrete temperature is approximately $175^{\circ} \mathrm{F}$. Case 2 should be considered the baseline case until the final siting arrangement is determined. Once final siting is determined, then the thermal radiation viewfactors can be calculated and the resulting temperature distributions determined.

The non-ventilated cask design was evaluated reference 6 . This analysis determined that the peak fuel and concrete temperatures were 482 and $198^{\circ} \mathrm{F}$, respectively. These temperatures are 25 to $35^{\circ} \mathrm{F}$ hotter than the ventilated cask assuming the same thermal boundary conditions. Therefore the ventilated cask appears to have some merit.

It is this author's recommendation that the no-wind condition be accepted as the baseline normal condition case. Even with this condition, the ventilated ISC should be acceptable. The CCC, DFA, and steel liner temperatures are all acceptable. The concrete temperatures are acceptable based upon past experience at Hanford, but this analysis should be reviewed by materials and structural analysts.

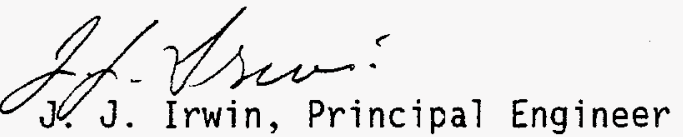

TWRS Thermat Hydraulics

CONCURRENCE:

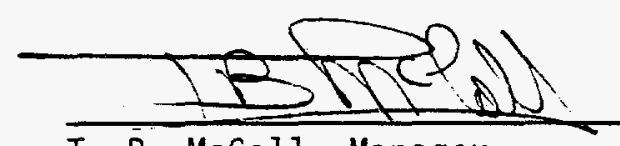

T. B. McCall, Manager

TWRS Thermal Hydrautics 
WHC-SD-FF-DRR-00018

Rev. 0

\section{ATTACHMENT 8}

TOTAL COMMENT PACKAGE WITH GENERAL ATOMIC'S DISPOSITIONS

A $8-1$ 
Mr. Curt E. Briggs, MSIN G1-64

Advanced Procurement Specialist

Westinghouse Hanford Company

2355 Stevens Drive

Richland, WA 99352

\section{SUBJECT: FINAL DESIGN REVIEW COMMENT RESPONSES \\ - WHC Purchase Order MDV-SXP-09735 I \\ GA Project 3682}

Dear Mr. Briggs:

Attached are General Atomics' (GA) responses to the final design review comments contained in your letters of July 29 and August 8, 1994 and the issues discussed at the July $21-22$ meeting in San Diego. Also enclosed is a computer disc of the text.

A few of the comments request work beyond the scope of our contract. GA has estimated the price of such items where possible in the attachment. In cases where the added scope affects cask construction, the price impact, if any, is being determined by GA's subcontractors. GA will provide any price increase for these items once it receives quotes from the subcontractors.

GA believes these responses resolve all of the WHC comments. Additionally, GA believes the cask design is sound and meets all of WHC's specification requirements. We look forward to closing out the comments prior to the design review meeting on August 24th.

If you have any questions regarding the attached responses, please contact ine at (619) 455-3422 or Jim Ruggles at (619) 455-2125 [fax: (619)455-3545].

$$
r
$$
Enclosures (2)
$\begin{array}{ll}\text { cc: } & \text { R. Grenier } \\ \text { M. Koploy } \\ \text { J. Ruggles }\end{array}$

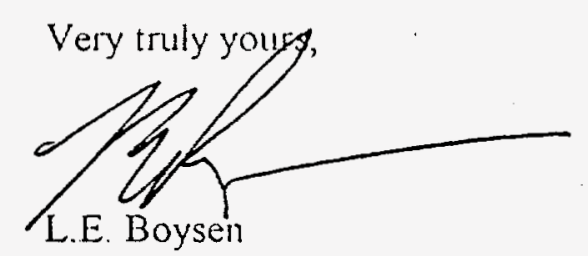

Director, Contracts and Purchasing

A8-2 
WHC-SD-FF-DRR-00018

Rev. 0

\section{ISC FINAL DESIGN REVIEW COMMENTS}

\section{DESIGN ANALYSIS REPORT}

\section{SECTION 1.0 GENERAL DESCRIPTION}

1-1) 1.2.1 first paragraph - clarify the radiation dose rates are limited to $2 \mathrm{mRem} / \mathrm{hr}$ at ISC surface when the CCC is in the stored position.

Response: The words "when the CCC is in the stored position" will be added to the last sentence of the first paragraph in Section 1.2.1

1-2) 1.2.1 add statement to cover tie-down equipment weight and trailer payload.

Response: The following words have been added to Section 1.2.3: "The tiedown equipment used in the lowboy to transport the cask weighs $3883 \mathrm{lbs}$. The total lowboy trailer payload including the cask and tiedown equipment is 117,823 lbs."

1-3) The operations section is not totally clear. Sketches are needed to facilitate the discussion.

Response: Section 1.3 has been revised as shown in appendix $\mathrm{A}$.

1-4) 1.3.1, Need to address the sequence of operation required with the Cask Loading Station shielding and sealing equipment and DSWC plug handling fixture. Include step that allows closure to sit on DSWC Floor valve. Describe how the existing tooling and interface equipment is used to accomplish closure installation per 3.2.4.4 of specification. Identify additional tooling required to accomplish the closure installation. Sketches would be useful.

Response: Section 1.3 has been revised as shown in appendix A.

1-5) 1.3.2, Need to address the sequence of operation required with the Cask Loading Station sealing and shielding equipment and DSWC plug handling fixture. Need to demonstrate how the design complies with section 3.2.5.6 of the specification. Identify additional equipment required to accomplish closure removal. Expand on the port cover removal requirements and replacement and if any precautions need to be observed during removal 
process. Sketches would be useful. How is closure removed if leak of CCC is discovered?

Response: Section 1.3 has been revised as shown in appendix A.

1-6) Expand the Leakage Testing section to include industry accepted evacuation and backfill practice to verify dry inert gas. Recommend what pressures the evacuations and backfills need to be performed at. A recommendation of a method of inter-seal monitoring would also be useful.

Response: Section 1.3 has been revised as shown in appendix A.

1-7) 1.3.6, Unclear how tie-down equipment will be hoisted and placed on ISC. In what state of assembly. Sketch would be useful.

Response: Lifting eyes will be added to top $x$-brace to provide improved lifting and handling capability. Tie down system could be fully assembled and draped over top of cask, or separated at top or bottom end of item 6 links. Overrotation of joints is prevented by "stop bar" (item 24 of H-4-302126), welded to top clevice assy (item 15).

1-8) 1.3.8, U-bolts not on drawing.

Response: The text in Section 1.3.8 item 4 has been changed to read:

4. Thread wires through two cover bolts to nearby holes in the cover; crimp wires with tamper-indicating seals.

1-9) 1.4, Is there action required to remove snow?

Response: No, there is no detriment to the cask, thermally or otherwise.

1-10) Need to include discussion on the recommended annulus boroscope inspection and duct and/or annulus cleaning. .

Response: The following will be added to the end of section 1.4 .

As an added precaution, if desired, the ducts and/or annulus can be cleaned by removing the expansion anchor bolts and duct screens and vacuuming and/or blowing air though the ducts. Since the ACI-349 long 
term temperature limitations are met even with the ducts plugged (see Chapter 4), there is no need to clean the ducts on a regular basis.

WHC may want to inspect the ducts and annulus with a boroscope before the cask is transported after being stored outside for a long period of time. This may be done by removing the duct screens and inserting a boroscope to view the inside of the duct system. This inspection is not required because of the low cask temperatures, as discussed above.

1-11) Is there any criteria that GA would recommend in regards to duct outlet temperature monitoring, if not, discuss the basis for not performing this.

Response: There is no need to monitor duct outlet temperature since the ACI-349 long-term temperature limitations are met even with the ducts plugged (see Chapter 4).

1-12) Need to address requirements for cavity sampling. Port cover removal requirements and replacements and any precautions. Address that the port cover removal and installation operations do not affect the closure seals.

Response: See Section 1.3.4 in appendix A. The port cover removal and installation operations if properly performed do not affect the closure seals. 
WHC-SD-FF-DRR-00018

Rev. 0

SECTION 2.0 DESIGN CRITERIA

2-1) 2.2, Closed CCC reference should be H-4-72005.

Response: This drawing number is not in the WHC-S-4110 specification. The drawing number will be removed from Section 2.2 .

2-2) 2.9.3, (page 2.9-2) Cask Loading Station drop should refer to RSB-CLS $70 g$ condition.

Response: The DAR was prepared before Mod. No. 2 to the contract was issued. GA accepted Mod. No. 2 on the basis that changes would not be implemented in the DAR and drawings without an equitable price adjustment. GA estimates the price for these changes to be $\$ 1,000$.

2-3) 2.11, (page 2.11-1) Need to define how confinement meets 10CFR72 72.236(e)

Response: The following paragraph will be added to section 2.11 .

The ISC is designed with redundant seals in the closure and redundant welds on the port cover to meet 10CFR72.236 (e). 


\section{SECTION $3.0 \quad$ STRUCTURAL}

3-1) Table 3.4-1, pg. 3.4-2. The loading condition "cold environment:-270 F ambient temperature" should include the case of zero decay heat per section 3.2.2.2.5.c (pg. 19) of the ISC Spec.

Response: This condition is given in Table $3.4 .1,3^{\text {rd }}$ line.

3-2) 20 foot drop at RSB-CLS - Clarify what is meant by the design appears to have margin to accommodate the $70 \mathrm{~g}$ drop. (pg. 3.4-14).

Response: GA did not know how Mod. No. 2 would read with regard to the load application when the DAR was written. See response to question 2-2.

3-3) Will certification be provided on the Nil Ductility Temperature of confinement materials?

Response: Yes, per flag 4 in drawing H-4-302135.

3-4) Could not locate where it is covered that the following statement of section 3.2.6 of the specification is addressed. "Each lifting device which is a structural part of the packaging shall be designed so that failure of the device under excessive load would not impair the confinement or shielding properties of the packaging."

Response: See page 3.5.4-11.

3-5) Need to provide results summaries or tables.

Response: Table 3.4-1 will be modified as follows: 
WHC-SD-FF-DRR-00018

Rev. 0

TABLE 3.4-1

SUMMARY OF LOAD COMBINATIONS FOR NORMAL HANDLING LOADS

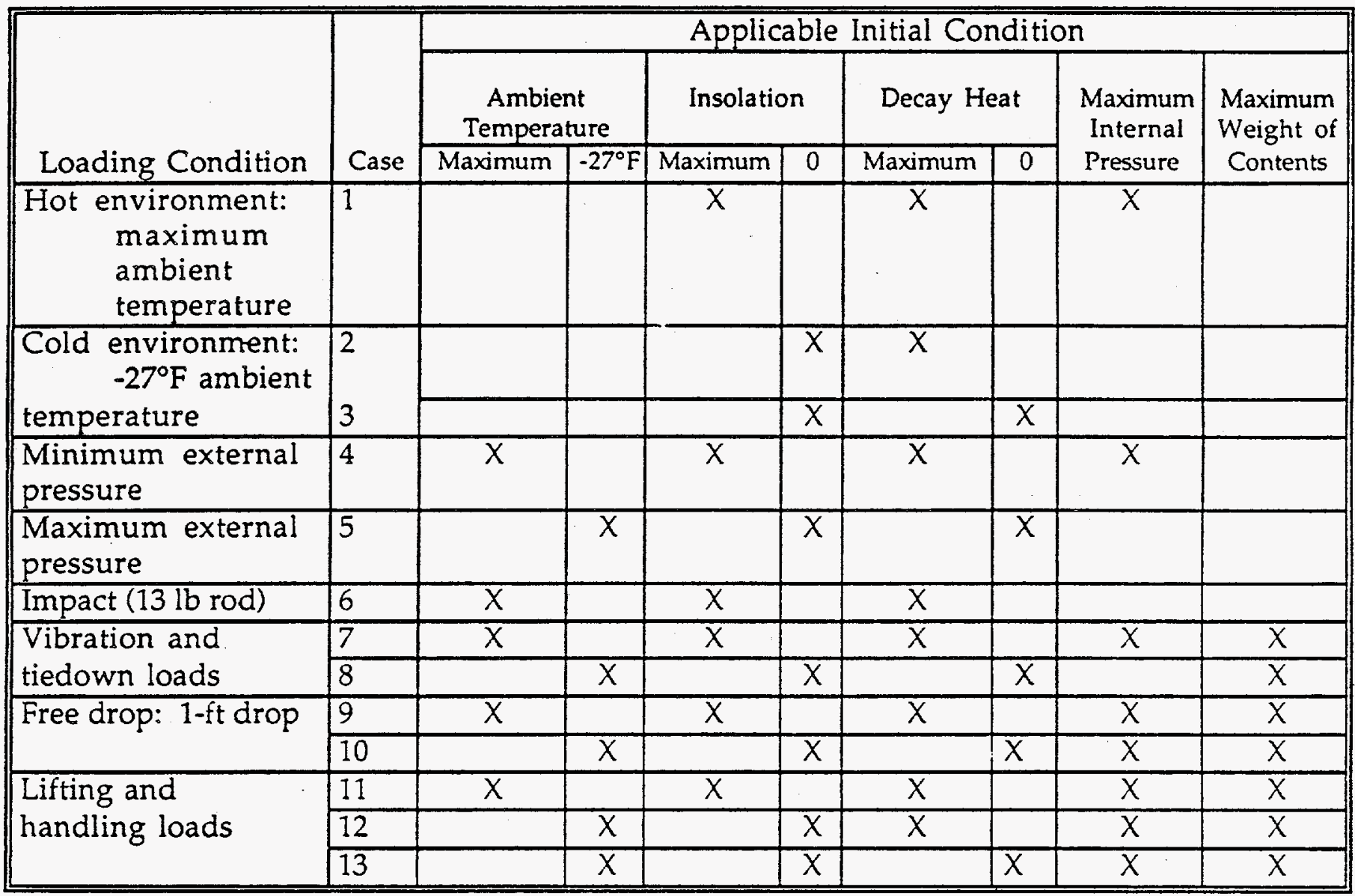

The following will be added to Section 3.4.1.1:

Confinement Boundary Stress Summary. Table 3.4-4 summarizes the highest stresses in the confinement boundary during the normal handling loads described in Table 3.4-1. All stresses are well below the allowables. The following sections explain how these stresses where computed and references the section where the stresses for the non-confinement boundary components were computed. 
WHC-SD-FF-DRR-00018

Rev. 0

TABLE 3.4-4

SUMMARY OF CONFINEMENT BOUNDARY STRESSES DURING NORMAL HANDLING LOADS

\begin{tabular}{|c|c|c|c|c|c|c|}
\hline Loading Condition & Case & Section & Component & $\begin{array}{l}\text { Stress } \\
\text { Type }\end{array}$ & $\begin{array}{l}\text { Stress } \\
(\mathrm{ksi})\end{array}$ & $\begin{array}{l}\text { Allowable } \\
\text { (ksi) }\end{array}$ \\
\hline $\begin{array}{l}\text { Hot } \\
\text { environment: } \\
\text { maximum } \\
\text { ambient } \\
\text { temperature }\end{array}$ & 1 & $\begin{array}{l}3.4 .1 .2 \\
3.5 .3 .4\end{array}$ & $\begin{array}{l}\text { liner } \\
\text { bolts }\end{array}$ & $\begin{array}{l}\text { Pm } \\
P_{m} \\
\text { (preload) }\end{array}$ & $\begin{array}{l}.217 \\
52.72\end{array}$ & $\begin{array}{l}21.1 \\
80\end{array}$ \\
\hline \multirow{2}{*}{$\begin{array}{l}\text { Cold } \\
\text { environment: } \\
-27^{\circ} \mathrm{F} \text { ambient } \\
\text { temperature }\end{array}$} & 2 & 3.4 .1 .3 & all & (a) & (a) & (a) \\
\hline & 3 & 3.4 .1 .3 & all & (a) & (a) & (a) \\
\hline $\begin{array}{l}\text { Minimum externa } \\
\text { pressure }\end{array}$ & 4 & 3.4 .1 .4 & all & all & negligible & - \\
\hline $\begin{array}{l}\text { Maximum external } \\
\text { pressure }\end{array}$ & 5 & 3.4 .1 .4 & all & ail & negligible & - \\
\hline Impact (13 lb rod) & 6 & 3.4 .1 .5 & all & all & negligible & - \\
\hline \multirow{2}{*}{$\begin{array}{l}\text { Vibration and } \\
\text { tiedown loads }\end{array}$} & 7 & 3.4 .1 .6 & all & all & negligible & 10.6 \\
\hline & 8 & 3.4 .1 .7 & all & all & (a) & (a) \\
\hline $\begin{array}{l}\text { Free drop: } 1-\mathrm{ft} \\
\text { drop ( } 3000 \text { psi } \\
\text { concrete)(end } \\
\text { drop) }\end{array}$ & 9 & $\begin{array}{l}3.5 .3 .4 \\
(3.5 .4 .10 .1 \\
\text { b) }\end{array}$ & $\begin{array}{l}\text { liner } \\
\text { liner }\end{array}$ & $\begin{array}{l}P_{m} \\
P_{m+b} \\
\text { (g level } x \\
\text { DLF) }\end{array}$ & $\begin{array}{l}16.54 \\
45.47 \\
(84.3 * 1.64= \\
138.3 g)\end{array}$ & $\begin{array}{l}21.1 \\
63.3 \\
(450 \mathrm{~g})\end{array}$ \\
\hline \multirow[t]{2}{*}{$\begin{array}{l}\text { Free drop: } 1-\mathrm{ft} \\
\text { drop ( } 4500 \text { psi } \\
\text { concrete) (end } \\
\text { drop) }\end{array}$} & 9 & $\begin{array}{l}3.5 .3 .4 \\
(3.5 .4 .10 .1 \\
\text { b) } \\
\end{array}$ & $\begin{array}{l}\text { liner } \\
\text { finer } \\
\text { bolts }\end{array}$ & $\begin{array}{l}P_{m} \\
P_{m+b} \\
P_{m} \\
\text { (g level } x \\
\text { DLF) } \\
\end{array}$ & $\begin{array}{l}19.18 \\
53.85 \\
61.8 \\
(126 * 1.27= \\
160 \mathrm{~g}) \\
\end{array}$ & $\begin{array}{l}21.1 \\
63.3 \\
80 \\
(450 \mathrm{~g})\end{array}$ \\
\hline & 10 & (a) & all & (a) & (a) & (a) \\
\hline \multirow{3}{*}{$\begin{array}{l}\text { Lifting and } \\
\text { handling loads }\end{array}$} & 11 & 3.4 .1 .9 & all & all & negligible & - \\
\hline & 12 & (a) & all & (a) & (a) & (a) \\
\hline & 13 & (a) & all & (a) & (a) & (a) \\
\hline
\end{tabular}

(a) The cold condition produces higher design margins than the hot conditions primarily because of the higher allowables and therefore is not recomputed. 
WHC-SD-FF-DRR-00018

Rev. 0

Current Table 3.4-4 (changed to 3.4-5 due to added table) will be changed as follows:

TABLE 3.4-5

SUMMARY OF LOAD COMBINATIONS FOR

HYPOTHETICAL ACCIDENT HANDLING LOAD

\begin{tabular}{|c|c|c|c|c|c|c|c|c|c|}
\hline \multirow[b]{3}{*}{ Accident Condition } & \multirow[b]{3}{*}{ Case } & \multicolumn{8}{|c|}{ Applicable Initial Condition } \\
\hline & & \multicolumn{2}{|c|}{$\begin{array}{c}\text { Ambient } \\
\text { Temperature }\end{array}$} & \multicolumn{2}{|c|}{ Insolation } & \multicolumn{2}{|c|}{ Decay Heat } & \multirow{2}{*}{$\begin{array}{l}\text { Maximum } \\
\text { Internal } \\
\text { Pressure }\end{array}$} & \multirow{2}{*}{$\begin{array}{l}\text { Maximum } \\
\text { Weight of } \\
\text { Contents }\end{array}$} \\
\hline & & \begin{tabular}{|l} 
Maximum \\
\end{tabular} & $-27^{\circ} \mathrm{F}$ & Maximum & $\overline{0}$ & Maximum & 0 & & \\
\hline \multirow{2}{*}{$\begin{array}{c}\text { Free drops:8-ft, } \\
4 \mathrm{ft}, \\
\text { onte MCLS, } \\
\text { tipover }\end{array}$} & 1 & $\bar{x}$ & & $\bar{x}$ & & $\bar{x}$ & & $\bar{x}$ & $\bar{x}$ \\
\hline & 2 & & $x$ & & $\bar{x}$ & & $\bar{X}$ & & \\
\hline \multirow{2}{*}{$\begin{array}{l}\text { Puncture: drop onto } \\
\text { bar }\end{array}$} & 3 & $\bar{x}$ & & $\bar{x}$ & & $\bar{x}$ & & $\bar{x}$ & $\bar{x}$ \\
\hline & $\longdiv { 4 }$ & & $\bar{X}$ & & $\bar{x}$ & $\bar{X}$ & & $\bar{x}$ & $\bar{x}$ \\
\hline \multirow[t]{2}{*}{ Dropped CCC } & 5 & $\bar{X}$ & & $\bar{X}$ & & $\bar{x}$ & & & $\bar{x}$ \\
\hline & $\overline{6}$ & & $\bar{X}$ & & $\bar{x}$ & & $x$ & & $\bar{x}$ \\
\hline $\begin{array}{l}\text { Thermal: fire, } \\
\text { plugged ducts }\end{array}$ & 7 & $\bar{x}$ & & $\bar{x}$ & & $\bar{x}$ & & $\bar{x}$ & \\
\hline
\end{tabular}

The following will be added to Section 3.4.2.1:

Confinement Boundary Stress Summary. Table 3.4-8 summarizes the highest stresses in the confinement boundary during the hypothetical accident handling loads described in Table 3.4-5. All stresses are well below the allowables. The following sections explain how these stresses where computed and references the section where the stresses for the nonconfinement boundary components were computed. 
TABLE 3.4-8

SUMMARY OF CONFINEMENT BOUNDARY STRESSES DURING HYPOTHETICAL ACCIDENT HANDLING LOADS

\begin{tabular}{|c|c|c|c|c|c|c|}
\hline Loading Condition & Case & $\overline{\text { Section }}$ & Component & $\begin{array}{l}\text { Stress } \\
\text { Type }\end{array}$ & $\begin{array}{l}\begin{array}{l}\text { Stress } \\
(\mathrm{ksi})\end{array} \\
\end{array}$ & $\begin{array}{l}\begin{array}{l}\text { Allowable } \\
\text { (ksi) }\end{array} \\
\end{array}$ \\
\hline \multirow{3}{*}{ 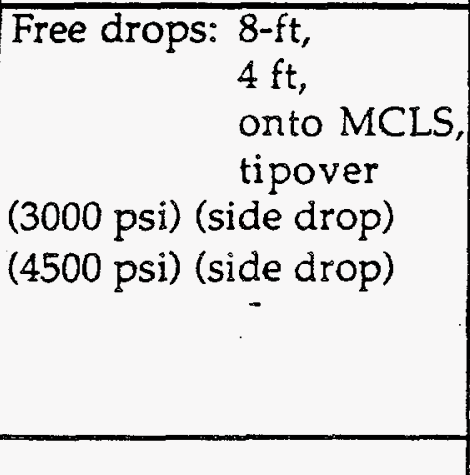 } & 1 & $\begin{array}{l}3.4 .2 .2 \\
(3.5 .4 .10 .1 \\
\text { b) }\end{array}$ & liner & $\begin{array}{l}\mathrm{Pm} \\
\text { (g level) }\end{array}$ & $\begin{array}{l}17.4 \\
(81.8)\end{array}$ & $\begin{array}{l}44.3 \\
(440 \mathrm{~g})\end{array}$ \\
\hline & 1 & $\begin{array}{l}3.4 .2 .2 \\
(3.5 .4 .10 .1 \\
\text { b) }\end{array}$ & liner & $\begin{array}{l}P_{m} \\
\text { (g level) }\end{array}$ & $\begin{array}{l}23.9 \\
(112.3)\end{array}$ & $\begin{array}{l}44.3 \\
(440 \mathrm{~g})\end{array}$ \\
\hline & 2 & (a) & all & (a) & (a) & (a) \\
\hline \multirow{2}{*}{$\begin{array}{l}\text { Puncture: drop onto } \\
\text { bar }\end{array}$} & 3 & 3.5 .7 .3 .3 & closure & $P \mathrm{Pm}+\mathrm{b}$ & 2 & 63.3 \\
\hline & $\sqrt{4}$ & (a) & all & (a) & (a) & (a) \\
\hline \multirow[t]{2}{*}{ Dropped CCC } & 5 & 3.4 .2 .4 & $\operatorname{CCC}$ & $\begin{array}{l}\text { (max.g } \\
\text { level) }\end{array}$ & $(350 \mathrm{~g})$ & $(440)$ \\
\hline & 6 & (a) & $\overline{C C C}$ & (a) & (a) & (a) \\
\hline $\begin{array}{l}\text { Thermal: fire, } \\
\text { plugged ducts }\end{array}$ & 7 & 3.5 .4 .11 & all & Secondary & negligible & - \\
\hline
\end{tabular}

3-6) Clarify what is meant by "meet the intent" of the ASME Code. (pg. 3.4-1).

Response: "Meet the intent " is commonly used to mean that the component is not stamped and that it is not inspected by an ASME authorized inspector. Page 3.4-1 will be revised to "is designed to meet the stress allowables of the ASME Code".

3-7) A figure to facilitate the load path discussion-is needed.

Response: Figure 3.4.1 will be added and referenced in the fourth paragraph in Section 3.4. 


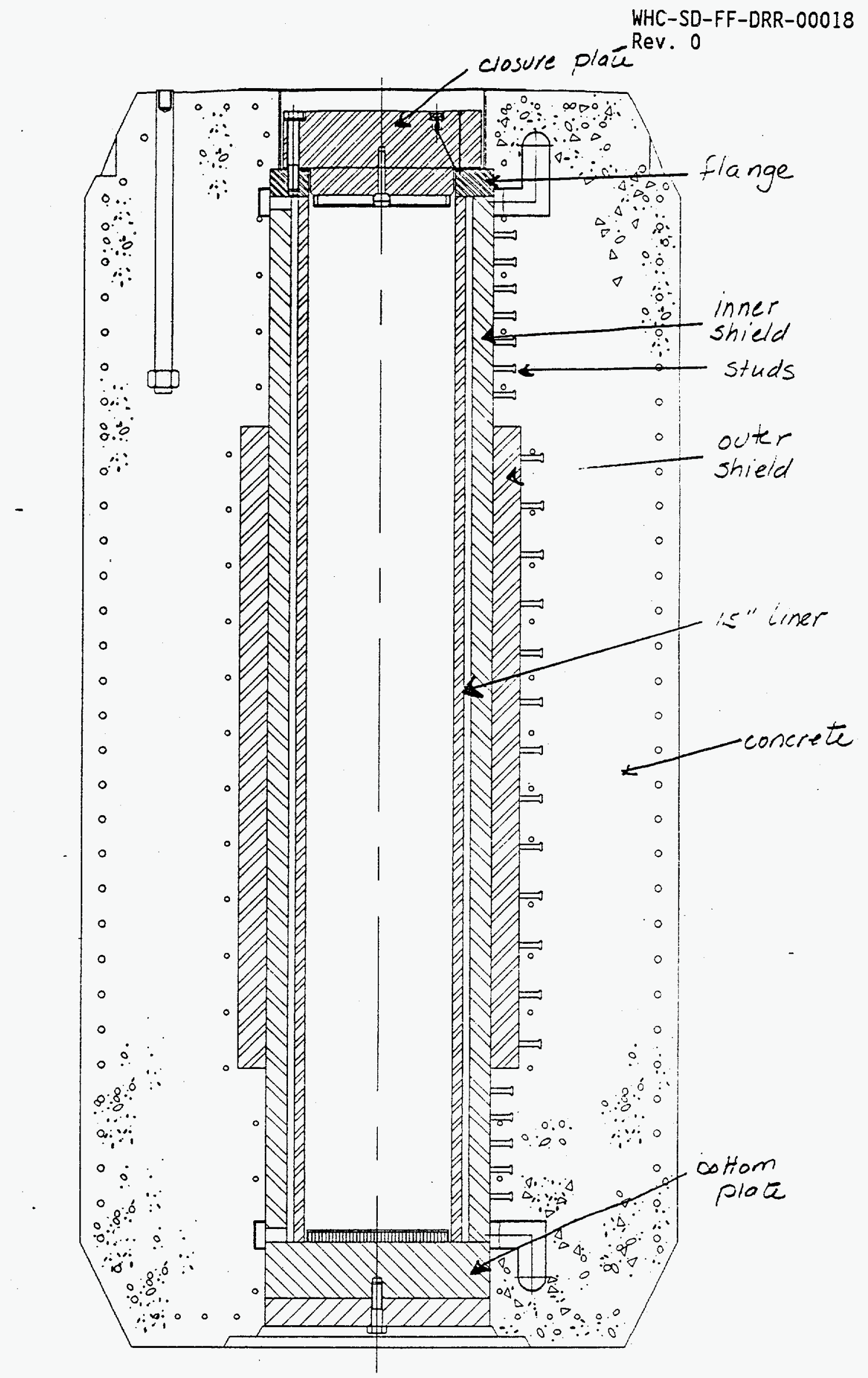

Fig. 3.4.1. ISC major componerts

$A 8-12$ 
WHC-SD-FF-DRR-00018.

Rev. 0

3-8) Page 3.5.2-4 and 3.5.6-1: It appears that the height of cask bounce before the secondary drop or tipover has not been considered, estimate how significant it is.

Response: As stated in Section 3.5.2.5, for a slapdown, both kinetic and potential energy remaining after the initial or primary impact are considered. Therefore, the "kick" given by the initial impact, which imparts a higher slapdown acceleration is taken into account. The elastic recovery energy after the initial impact is extremely small because the energy is being absorbed by crushing of a small layer of concrete and not by deformation of long elements. This is standard practice in impact analysis of casks.

3-9) Page 3.5.3-4: Please list the sources or references where the total loadings at bottom head, inner cylinder, Core Component container and closure were calculated or obtained.

Response: The following will be added to Page 3.5.3-4:

bottom head

inner cylinder

CCC

closure

$$
\begin{aligned}
& 2731=\pi / 4(32)^{2}(8+4)(.283) \\
& 4532=\pi / 4\left(24^{2}-21^{2}\right)(149.46+1.56)(.283) \\
& 5000=\text { from pg. 3.2-1 } \\
& 1816=\pi / 4\left[\left(28.25^{2}\right)(8)+\left(25.5^{2}\right)(4)+\left(20.5^{2}\right)(.25)\right](.283)
\end{aligned}
$$

3-10) Page 3.5.4-13: In the calculation, tensile stress of concrete $=$ $(4)(.85)(3000)=186$ psi, may have a calculation error?

Response: There is a square root sign missing, the text will be corrected to read:

$$
\begin{aligned}
\text { Tensile strength of concrete } & =4(.85)(\sqrt{3000} \mathrm{psi}), \\
& =186 \mathrm{psi} .
\end{aligned}
$$

3-11) Page 3.4.4-23 and 3.4.4-29: Correct Table 4-4 to Table 4-6, for recommended Damping values in UCRL-15910, latest version published June 1990. Please justify the $10 \%$ damping is applicable to impact analysis.

Response: The table numbers will be changed fr- 1 4-4 to 4-6.

For justification of damping read section 3.5.3.10.1 and the changes discussed in response to question 3-12. For further information on the use of DAF and damping see response to previous structural question in GA letter dated April 
WHC-SD-FF-DRR-00018

Rev. 0

15, 1994. Appendix B of that letter has been included in this package for easy reference.

3-12) Page 3.5.4-26 and 3.5.4-29: please show how Dynamic Load Factors, I.e., 0.81, 0.8, $0.7,0.56,1.90,1.64$ et.al were calculated? $13.5 \%$ reduction is acceptable.

Response: Page 3.5.4-23 describes how the Dynamic Load Factors (DLF) are calculated. To facilitate understanding, the last paragraph will be modified as follows:

The 1-ft and 4-ft drops DAF are calculated as follows:

1. Calculate impact time using conservation of impulse.

2. Calculate-the cask fundamental mode of flexural vibration for the side drops and axial vibration for the end drop,

3. Compare the structure period of vibration (step 2) to the duration of the load (step 1)

4. Calculate the DLF using the appropriate response curve (based on step 3) for a rectangular load pulse (use fig. 3.5.4-4). For the 4-ft drops, a ductility ratio of 1.3 is conservatively used for all drop orientations. For the 1-ft drop (normal conditions), no ductility ratio is used.

5. Reduce DAF by $13.5 \%$ to account for $10 \%$ structural damping per Biggs, Introduction to Structural Dynamics, p. 55 and Table 4-6 "Recommended Damping Values" in UCRL-15910. Damping is appropriate for this type of loading because the source of load is the crushing of concrete in the structure itself. In addition, the load path provides for interaction between multiple components depending on relative motion (friction) and cracking of concrete to react the load. The approached used ignores the energy dissipated as the initial shock waves from the impact resonate through the cask, and only accounts for the energy dissipated due to vibration of the cask's first natural frequency.

Damping is used only to reduce the DAF. If the calculated DAF is less than 1 , a DAF equal to 1 is used.

3-13) Page 3.5.6-2: 1st equation, dS is not defined, please clarify? 3rd equation d $\Delta$ should be $d x$ since $d \Delta$ has already been integrated.

Response: There were several typos in that page, the first four equations should read as follows:

$\Delta E=V_{\text {crush }}\left(\dot{f}_{c}^{\prime}\right)=\int_{0}^{\frac{x}{L} \delta} \int_{0}^{\max }\left(f_{c}^{\prime}\right)(S(\Delta)) d \Delta d x$ 
WHC-SD-FF-DRR-00018

ReY. 0

$$
\begin{aligned}
& S(\Delta)=2 \sqrt{R^{2}-(R-\Delta)^{2}}=2 \sqrt{\Delta^{2}+2 R \Delta}=2 \sqrt{2 R \Delta} \\
& \Delta E=f_{c} \int_{0}^{L} \frac{x}{L} \delta_{0} 2 \sqrt{2 R \Delta} d \Delta d x=f_{c}^{1} \int_{0}^{L} 2 \sqrt{2 R} \frac{2}{3}\left(\frac{x}{L} \delta_{\max }\right)^{\frac{3}{2}} d x \\
& =\frac{4}{3} \sqrt{2 R} f_{c}^{\prime} \frac{1}{L^{1 / 2}} \delta_{\max ^{3 / 2}} \frac{2}{5} L^{5 / 2}=\frac{8}{15} L \sqrt{2 R} f_{c} \delta_{\max ^{3 / 2}}
\end{aligned}
$$

3-14) Appendix $C$ (Computer Code SAC outputs) It appears that the ring section has sustained a fairly high stress, i.e. page C $049,11,848$ psi is this concrete stress or steel stress? Or if this stress is for steel, how about buckling effects on thin shell or at discontinuity section?

Response: As described in Section 3.5.3, the SAC analysis was used to analyze the all-steel confinement boundary. The analysis represents a bottom end drop. During this event, the confinement boundary liner experiences a tensile stress due to the CCC and bottom plate weight. Page C048 shows that a tensile membrane stress of $21.05 \mathrm{ksi}$ (See also Page 3.5.3-10) is produced in the liner wall, even at the discontinuity, therefore, buckling is not a concern. The compressive stress on the ring is due to bending stress as described in page 3.5.3-10, this type of loading is not of concern from the standpoint of buckling of the thick ring.

3-15) WHC is pleased with the comparison approach of GACAP to DYNA3D. However, WHC is not yet satisfied with the data provided for verification of the GACAP code. WHC would like to see a comparison between GACAP and DYNA3D for a concrete structure which responds differently from steel structures under impact loading. It is believed that a concrete element behaves quite differently from a general purpose element.

General response to 3-15, 3-16 and 3-17. Additional verification work is out of the scope of this contract, and can be performed at additional cost. For a better understanding of the usage of the codes in the ISC analyzes please review GA responses to WHC structural comments in the letters dated: February 24, April 5, and June 20, 1994.

Specific response to 3-15: GA used GACAP to predict the loads and forces acting on the concrete structure. The behavior of the concrete reacting to these loads is 
WHC-SD-FF-DRR-00018

Rev. 0

calculated by hand per ACI-349 criteria. There is no reason to validate a concrete finite element.

3-16) WHC would like to see that ILMOD be verified against a concrete element of either one of the following codes: ANSYS, ABAQUS, or DYNA3D. Please also provide us with the theoretical backgrounds and approaches used in the ILMOD code.

Response: ILMOD is a geometry based code. It calculates areas and multiplies the areas by a user supplied stress. It cannot be compared to the above codes.

3-17) Please have the SAC code verified against either one of the following codes: ANSYS or ABACUS. Show applicability to asymmetrical loading conditions and discontinuities.

Response: SAC is an axisymmetric code used to analyze only axisymmetric loads during the end drop. There are no asymmetrical loads for this drop orientation. The SAC code validation was provided in $2 / 11 / 94$. GA sees no need or value in further verification.

3-18) Page 3.5.4-47, Please replace with legible copy.

Response: Attached. 
4-1) Page 4.1-3, What is the significance of the 17 inches of concrete $<350^{\circ} \mathrm{F}$, in other words, what is the minimum safe shielding for the concrete in comparison to that amount affected by this accident?

Response: The required concrete shielding for accident conditions is 2 in. as stated in Sec. 5.4.5. This will be noted.

4-2) Page 4.3-1, the 0.225 in gap between the outer and inner shield is stated to be important to cask thermal performance. How is this controlled? And how is concrete prevented from entering the gap in the construction?

Response: The statement means that the gap in question presents the greatest thermal resistance of all gaps due to its thickness and extent. The value of $0.225 \mathrm{in}$. used in the analysis is the maximum local gap thickness averaged around the circumference. (Note that the gap is 0 at two places $180^{\circ}$ apart where the two halves of the outer shield ring contact the inner ring.) This will be clarified in the DAR. The junction between inner and outer rings is taped at the top and bottom to prevent concrete from entering the gap. From purely thermal considerations concrete in the gap is of no consequence.

4-3) Please state for completeness the source of gas from radioactive decay as in the specification. "The generation of gases produced by radioactive decay is expected to be 5.4 gram-atoms (moles)/assembly or $32.4 \mathrm{gram}$-atoms/iSC for a 50 year period assuming that all free gases contained within the fuel rod cladding are released."

Response: The change will be incorporated as requested.

4-4) Page 4.3-1, 4th paragraph, 2nd sentence, "3-in. space between the closure and the 'cover' plate".

Response: The change will be incorporated as requested.

4-5) Pressure calculation 4.5.3.9 - The CCC solid volume is $2.45 \mathrm{ft}^{3}$.

Response: The CCC volume was calculated from information given in the Specification. Use of $2.45 \mathrm{ft}^{3}$ would result in a slightly higher pressure but would not exceed 3: $\mu$ sig for the maximum fuel cavity average temperature of $268^{\circ} \mathrm{F}$.

4-6) Section 4.1.3, pg. 4.1-3. The thermal analysis should also include helium in addition to argon as a possible inerting gas per sections 3.2.2.1.9 and 3.2.2.2.2 (pgs. $17 \& 18$ ) of the ISC Spec. 
WHC-SD-FF-DRR-00018

Rev. 0

Response: CCC temperatures will be reduced by helium since its thermal conductivity is significantly greater than argon. Therefore the use of argon is conservative. Outside the CCC envelope, the cask temperatures will be unaffected by the backfill gas since the heat generation is fixed at $1500 \mathrm{~W}$. A statement to this effect will be added to the DAR.

4-7) Sect. 4.3.2, pg. 4.3-10. The thermal analysis should also address the heavily oxidized paint condition in accordance with section 3.2.2.2.9 (pg. 24) of the ISC Spec.

Response: A heavily oxidized surface has a high emissivity, which is already assumed in the analysis. The only significant thermal result that may accompany degradation of the paint is an increase in the solar absorptivity. This situation has been bounded by case 6 (ash with plugged ducts) in which the absorptivity was increased to 0.8 . A statement to this effect will be added to the DAR. Note that the maintenance recommends repainting if the paint is chipped, spalled, discolored, or has other surface defects.

4-8) Page 4.1-3, Section 4.1.3, The discussion of how concrete temperatures meet ACI-349 for the various conditions.

For long-term limit condition: Need to define the extent of the local temperatures above $150^{\circ} \mathrm{F}$ in the text, describe specifically what area is affected. ACI-349 does not refer to bulk or average concrete temperature requirements. Clearly define how these are calculated. In earlier correspondence GA provided background information that justified that the concrete does not lose strength below $200^{\circ} \mathrm{F}$. This information needs to be included in these discussions to back-up the acceptability of localized temperatures above $200^{\circ} \mathrm{F}$.

For off-normal condition: Need to define the extent of the local temperatures above $150^{\circ} \mathrm{F}$.

For the Plugged duct discussion: Need to define the extent of the local temperatures above $150^{\circ} \mathrm{F}$. It is questionable whether this can still be considered local but emphasis could be placed on the justification mentioned above. Also, the case needs to be built that justifies not recommending duct outlet temperature monitoring. Since, per the justifi-mion, the concrete does not lose strength at temperatures less than $200^{\circ} \mathrm{F}$ this case could possibly be made based on this accident condition.

Response: As shown in the isotherm plot of Fig. 4.3-6, for long-term normal conditions only a very small portion of the concrete, in the top corner area between the inner and outer shields, is above $150^{\circ} \mathrm{F}$. 
Several volume-averaged concrete temperatures are computed, as shown in Table 4.3-2. The "outer shield" average is taken over the length of the outer shield; the "shield" average is over the length of the inner and outer shields; and the "overall" average is over the entire volume of concrete.

Figure $4.3-7$ shows the extent of the concrete above $150^{\circ} \mathrm{F}$ for off-normal severe conditions.

Figure 4.3-13 shows the extent of the concrete above $150^{\circ} \mathrm{F}$ for the plugged duct condition.

Appendix $D$ will be included to provide information showing that the concrete retains strength at temperatures below $200^{\circ} \mathrm{F}$. For all cases except the fire accident the concrete (overall) average temperature is $\leq 139^{\circ} \mathrm{F}$ and the maximum local temperature is $\leq 177^{\circ} \mathrm{F}$. Outlet duct temperature monitoring is therefore not required. 
5-1) There are two concerns with the PATH correction factor calculation presented in Section 5.0. First, a ratio of calculated to measured radiation levels for the VSC-24 and MTC casks is reported as 3.1. What assurance do we have that the actual radiation source that was present in the casks during the measurements was actually the maximum as was probably assumed in the calculations? It seems credible that the actual radiation source was much less than assumed in the shielding code calculations. For example, the radiation source specified for the FFTF ISC is larger than most if not all of the actual fuel assemblies. If radiation level measurements were made after fuel assemblies were loaded into the cask, the ratio of calculated to measured radiation levels would probably be substantially greater than one. However, this would not necessarily mean that the shielding code was conservative since other factors, such as, conservatism in the source could also explain the difference. Second, what assurance do we have that the radiation energy spectrum of the source is the same or similar between the VSC-24, the MTC and the ISC?

Response: The PATH correction factor calculation presented in Section 5.0 is for the actual fuel loaded in the VSC-24 at the Palisades Nuclear Station (Ref. 5-6 of Design Analysis Report). The fuel source terms used in the analysis are for 33 GWd/MTU burnup and 10 year cooled fuel, which represents the average burnup and cooling time of the fuel loaded in the cask. The burnup calculations performed by the reactor owners are used to predict start-up reactivity and the startup reactivity must be within $\pm 1 \%$ in $k_{\text {eff }}$. This gives high confidence that the burnup predictions are accurate. EPRI/DOE have also measured assembly burnups using the FORK measurement system at the Oconee Nuclear Station of the Duke Power Company (Ewing, R. I., "Burnup Verification Using the Fork Measurement System," High Level Radioactive Waste Management Proceedings Vol. 2, 1994). The results of the measurements show that the assembly burnup from the plant records are within $\pm 2.2 \%$ of the measured values. Therefore it may be concluded that the source used to determine the correction factor is consistent with the source in the measured cask. Pages 5.5-17 and 18 of the Design Analysis Report explain how the correction factor is determined for the ISC cask. The difference between the factor of 2 used for the ISC and the factor of 3.1 found with the MCNP code for the VSC-24 cask is due to the difference in relative concrete and steel thicknesses in the two cask designs.

The figure below shows that the gamma spectra for the two fuel types are very similar. The FFTF spectrum is somewhat harder. However, this will have little effect on the ratio of measured to calculated dose rates because the 
WHC-SD-FF-DRR-00018

Rev. 0

gamma absorption and scattering cross sections and the flux to dose rate conversion factors are very well behaved.

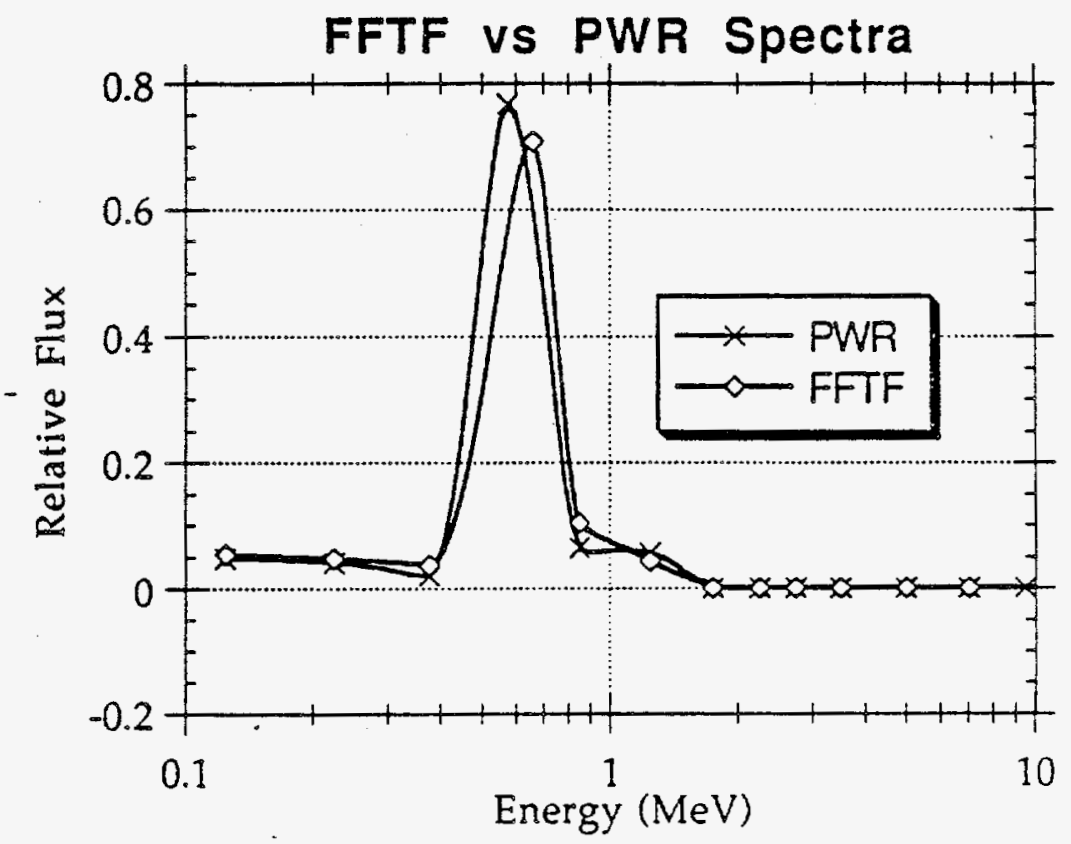

5-2) Sect. 5.3.2,pg: 5.3-6. The last sentence of Sect. 5.3.2 should be revised to read: "The neutron source term decays with age, in addition, even doubling the neutron dose rate does not significantly increase the total surface dose rates on the ISC."

Response: Sentence revised to read as requested.

5-3) Sect. 5.4.3,pg. 5.4-2. The standard ANSI/ANS 6.1.1-1977 that was used for the flux-to-dose conversion factors has been replaced by ANSI/ ANS 6.1.1-1991 according to the Hanford Kaiser Library.

Response: GA used ANSI/ANS 6.1.1-1977 as the NRC has not yet accepted A. viI/ANS 6.1.1-1991. In addition, based on a review of the two standards, it is conservative to use ANSI/ANS 6.1.1-1977 as ANSI/ANS 6.1.1-1991 would effect lower dose rates for the ISC cask. 
5-4) Shielding - How are you controlling the concrete minimal radial thicknesses of $21.25^{\prime \prime}$ and $25.25 "$.

Response: The concrete minimum radial thickness is controlled by the fabrication drawings. In addition, following fabrication, the cask will be gamma scanned to ensure sufficient shielding is provided.

5-5) 5.4.5, How does the concrete condition assumed for the accident dose analysis compare to the worst case hypothetical accident structural results?

Response: The following sentence will be added to Section 5.4.5:

The maximum crush of the concrete during a free drop accident is 6.19 inches in the corner as given in Table 3.5.2-8. This leaves approximately 19 inches more concrete than is assumed in the shielding calculations. The maximum local penetration during a puncture drop accident is 11.12 inches as shown in Section 3.5.7.2. This leaves at least 10 inches of concrete which is 8 inches more than was used in the shielding analysis.

5-6) A results table would be helpful.

Response: The following paragraph and Table 5-1 has been added to the Design Report at the end of Section 5.1.

A summary of the results of the analyses are shown in Table 5-1. These results show that the radiation levels outside the cask are all within the dose rate limits defined in the specification (Ref. 5-1). 
Table 5-1

Summary of ISC Dose Rates

\begin{tabular}{|c|c|c|c|c|}
\hline & \multicolumn{3}{|c|}{$\begin{array}{l}\text { Dose Rates } \\
\qquad(\mathrm{mR} / \mathrm{h})\end{array}$} & $\begin{array}{r}\text { Ref. } \begin{array}{r}5-1 \\
(\mathrm{mR} \\
/ \mathrm{h})\end{array}\end{array}$ \\
\hline \multicolumn{5}{|c|}{ Normal Conditions } \\
\hline ISC Surface & $\gamma$ & $\mathrm{n}$ & Total & Limit \\
\hline Top (max.) & 1.99 & $<0.01$ & 1.99 & 2.0 \\
\hline Side (max.) & 1.35 & 0.02 & 1.55 & 2.0 \\
\hline $\begin{array}{l}\text { Bottom } \\
\text { (max.) }\end{array}$ & 1.96 & $<0.01$ & 1.96 & 2.0 \\
\hline $\operatorname{TR}^{(1)}(\max )$. & 0.62 & $<0.01$ & 0.62 & 2.0 \\
\hline Top (Avg.) & 0.95 & $<0.01$ & 0.95 & 2.0 \\
\hline Side (Avg.) & 0.81 & 0.05 & 0.86 & 2.0 \\
\hline $\operatorname{TR}^{(1)}$ (Avg.) & 0.31 & $<0.01$ & 0.31 & 2.0 \\
\hline \multicolumn{5}{|c|}{ Hypothetical Accident Conditions } \\
\hline $1 \mathrm{~m}$ from ISC & $\gamma$ & $\mathrm{n}$ & Total & Limit \\
\hline Side Peak & 250 & 250 & 500 & 1000 \\
\hline
\end{tabular}

(1) $T R=$ tapered region

* Agreed in Final Design review
to correct to $0.2 \mathrm{mR} / \mathrm{m}$ 
6-1) Sect. 6.1, pg. 6.1-1. The maximum height and diameter of the ISC to assure interface compatibility with the RSB and RSB-CLS structure should be stated in the text (maximum of 182" ht. by 92 " diameter per pg. 40 of the ISC Spec.).

Response: The following sentence will be added to Section 6.1:

The ISC is $84.64 \mathrm{in}$. diameter $\times 180.41 \mathrm{in}$. tall without the cover plate, which meets the limits defined in WHC-S-4110, Sections 3.2.2.1.6 and 3.2.4.1.

6-2) Sect. 6.2.1, pg. 6.2-1. The text refers to the MASF 200-ton crane, 75-ton Hydraset, and 85-ton shackle. According to pgs. 14, 40, and 41 of the ISC Spec, the RSB handling equipment consists of the 100-ton RSB crane, 75-ton (or 150-ton) Hydraset, and 100-ton shackle.

Response: Will revise Sect 6.2.1 to refer to correct capacities.

6-3) Sect. 6.2.2, pg. 6.2-1. A statement should be added that the weight of the ISC with a $5000 \mathrm{lb}$ payload plus the tiedown equipment does not exceed the transporter payload limit of $120,000 \mathrm{lbs}$ (pg. 17 of the ISC Spec.)

Response: Will revise write-up.

6-4) ECN 152263 for drawing H-4-65152 shows insert tubing is used with the $11 / 2$ " HEX Head bolts to attach the center plate to the DSWC Trailer. Please add this to the bolt assembly for the ISC center plate also.

Response: Will add inserts to ISC plate bolting. (Note that incorporation of the tightly toleranced bolts in the existing trailer bolt holes requires "matchdrilling" of the ISC plate and tiedown mounting lugs per dwg. note 14)

6-5) 8.0, Tie-down design, ASTM A-514 (Fy = $100 \mathrm{ksi})$ listed for plates, drawing lists ASTM A-36 as the material. This affects parts 17, 18 and 20.

Response: Will revise drawing to match design calculations.

6-6) 8.2, Tie-down Trailer Bracket, Base Plate Bending, Section A-A should use 8 instead of 12.5 for $b$. 
Response: Will adjust calculations accordingly.

6-7) 8.3 Strut Bolt Bending - unable to confirm a 100 psi Fy for ASTM A-325.

Response: $100 \mathrm{ksi}$ allowable is too high. Will revise calcs accordingly. 


\section{SECTION $7.0 \quad$ ACCEPTANCE TESTS}

7-1) The specification requires the leak testing to be performed on the completed shielded ISC.

Response: Industry practice is consistent with GA's plans to perform the leak testing of the confinement boundary when the confinement boundary is completed. This means that no more fabrication will be performed on the confinement boundary. At this time, it can be shown that the leakage requirements are not only met for the closure seal, but also for the remainder of the confinement system.

7-2) Shielding tests - Does this method verify the dose rate at the vents?

Response: This method does not verify the dose rate at the vents because a standard cannot be built with which to compare the gamma scan results. There is no gamma scan methodology which can be used to verify the dose rate at the vents. The only way to test the vents is to actually load the fuel into the ISC and take dose rate measurements around the vents. 


\section{DRAWINGS}

\section{H-4-302134 ISC OUTLINE/INTERFACE SYSTEM}

8-1) The closure alignment pins are long. Has GA considered the possibility of binding during remote installation of the closure?

Response: The alignment pins must be this long for them to fuction correctly. The pins provide a 0.12 -in. radial clearance with the closure's bolt hole ID during most of the installation, which allows a tilt of $1.8^{\circ}$ before binding could occur. The clearance reduces to 0.06 -in. when the closure is 0.5 -in. above the flange, where binding is no longer a serious concern.

\section{H-4-302135 ISC ASSEMBLY}

9-1) The cask perpendicularity is controlled per note 38 to the O.D. of items 8 and 9. How are items 8 and 9 controlled to the I.D. of the cask (item 5) so that the drawing requirement of the I.D. perpendicular to the base is assured? Will this be measured directly at final inspection?

Response: To avoid the additional tolerance by taking measurements from the outside of items 8 and 9 , note 38 will be revised as follows;

With the cask in a vertical position, and prior to installing items 22,38 and 39 , the steel vendor shall hang three plumb lines $120^{\circ}$ apart from the top of the cask. Permanently shim item 7 at two places $120^{\circ}$ apart such that the distance from item 5 , measured through the 2.0 square openings in items 8 and 9, does not vary by more than .06 at each of the three locations. (First assure that the surface under item 7 is level within 075 . $)$ Datum $B$ is the plane at the bottom of the shims. The portion of each shim under item 7 shall be at least $10 \mathrm{in}^{2}$.

The measurement and shim adjustment will be made while access is still available to the 2.0 -in. square holes, so inspection will be made during fabrication and not at final inspection.

9-2) How is the O.D. of the cask controlled to the I.D.? How will final inspection be performed?

$$
\text { Q corrected } 91221940.15 \text { PCS }
$$


Response: The final fabrication method is under development by our subcontractor. The purpose of the drawing concentricity requirements is to assure adequate concrete thickeness for shielding. This will be confirmed by the gamma scans.

9-3) Per note 38 the shims under item 7 establish datum B. Therefore, is the hole in item 7, which per the drawing is located to datum B, drilled after shimming? Also, how is this hole located to the I.D. of the cask (datum A)? How will final inspection be performed?

Response: The tolerance callout was intended to apply to the Ø1.5-6 tapped hole, not the $\varnothing 1.562$ clearance hole; this will be corrected. Datum $B$ will be deleted as a secondary datum.

How the tapped hole is located and inspected is up to the fabricator. However, the tapped hole will be hidden after installation of items 7 and 18 , so inspection of the hole's location must be performed prior to such installation.

9-4) The environmental cover does not protect the lifting attachments from accumulation of dust, dirt, and moisture per section 3.2.2.1.10 of specification. The proposed ISC's environmental cover did.

Response: The attachment anchor tapped holes are filled with lubricated cover bolts, preventing dust, dirt and moisture from entering them. In addition, the tops and exposed sides of the anchors are galvanized and painted. The anchors are fully protected from the environment, certainly at least as protected as they were in the proposed ISC concept. The proposed design is better than putting the gasket outboard of the bolts. The outboard gasket design would require that some method be used to seal the hole around the cover bolts. If for some reason, water were to leak through these holes, then moisture would be trapped inside the cover. In the present design, water is prevented from being trapped inside the cover. In the present design, the only exposed surface is the concrete, which will not degrade in the presence of dust, dirt or moisture. As specified in 3.2.2.1.10, the concrete surface is sloped to minimize accumulation of dust, dirt, and moisture.

9-5) Some parts are not identified by manufacturer.

Response: Parts not identified by manufacturer are either raw materials or nonsafety related equipment that can be sourced by the fabricator. 
9-6) Notes 30 and 36 appear to conflict. Some tack welds of parts $38 / 39$ require preheat while others do not.

Response: The first sentence of note 30 will be deleted to eliminate the weld size conflict. Pre-heat is only required for welds to the confinement boundary; notes will be modified to clarify this requirement.

9-7) A bottom duct view would be helpful.

Response: A view of the ducts from the bottom is just a mirror image of the ducts as seen from above. There is no significant benefit in providing additional views.

9-8) Note 38, Is taping required to keep concrete from entering the gap between parts $38 / 39$ and $8 / 9$ ?

Response: No. We are only concerned with concrete entering the ducts and channel. Concrete will not flow through the .12 max gap between items 8 and 9 , and the exposed areas of these items are only taped for extra protection. There is no need to tape items 38 and 39.

9-9) The north arrow alignment does not correspond to the Cask Loading Station upper support pads.

Response: The lines and arrows defined in notes 40 and 41 will be moved to the horizontal centerline in the item 1 assembly plan view shown on sheet 2 .

9-10) When welding the A-516 Gr 70, use low hydrogen induction welding techniques to prevent hydrogen induction.

Response: The final fabrication method is under development by our subcontractor. Welds will meet applicable fabrication criteria.

9-11) In note number 3, Is 2 hours sufficient time for PWHT? Usually it is 2 to 3 hours per 1 inch of thickness.

Response: See table NC-4622.1-1 for PWHT requirements, table NC-4622.4(c)-1 for alternate holding times, and table NC-4622.7(b)-1 for exemptions to mandatory PWHT. The latter table (per note 4) allows reduced PWHT for cladding to P1, Groups 1 and 2, materials over 3-in. thickness`.

PWHT = Post Weld Heat Treat 
9-12) Detail J, it might be clearer if the .12 fillet weld had an all around weld symbol on it.

Response: Agreed.

9-13) In notes 19 and 24 it calls out for a tack weld. Preheat is just as important for tacks if on thick base metal.

Response: The amount of preheat required, unless otherwise specified by the Code, is determined by the manufacturer in accordance with his weld procedure qualifications, and is specified in the weld procedure. See NC-4611 and Section IX, QW-406.

9-14) WHC needs to review and approve GA's Welding Procedure Specifications (WPS's), Procedure Qualification Records (PQR's) and Welder Qualification Records (WQR's). Will these be provided with the fabrication plan?

Response: Will provide as soon as subcontractor can supply them.

9-15 Nil Ductility Temperature (NDT) less than -50 degrees $F$ is pretty low for A516 in the 4-8 in. thickness range. (e.g. NUREG / CR-1815 gives NDT range of -30 degrees $F$ to +30 degrees $F$ ).

Response: Values in Table 3 of NUREG/ CR-1815 typically give conservative values because they are based on using the upper bound values to show the material meets toughness criteria without additional testing. Our manufacturer chose A-516 GR 70 given the NDT temperature requirement of $-50^{\circ} \mathrm{F}$.

9-16) One of the comments under note 4 imposes special NDT requirements on Items 11 and 12, but in the Parts List, only Item 12 is marked with the mark of note 4. It would seem to be in error in the Parts list that Item 11 is not marked with the 4 .

Response: Flag 4 will be added to item 11.

9-17) Along same line as comment 9-16 above, is it really intended that Item 7 in the parts list is not subject to note 4 , or is there an omission? If there is not an error in the Parts List, the implication is that brittle fracture protection is not as important for Item 7 . Is this true?

Response: Item 7 does not require NDT temperature limitations since it is used only for shielding and is not part of the confinement boundary.

9-18) The use of Note 37 for Item 3 on the Parts List is not clear. The basic selection of A516 is without any restriction on NDT (i.e. could be +30 degrees F), yet 
there is requirement for full UT, and the alternate material (A203) is expected to have a much lower NDT.

Response: Item 3, like item 7 is not part of the confinement boundary. Therefore, it has no NDT temperature requirement. The requirement for full UT for items 3 and 7 is done not for structural purposes, but to verify the effectiveness of the shielding as the gamma scan is done only for the side of the cask. UT will demonstrate that there are no voids in the steel shields.

\section{H-4-302136 ISC TIEDOWN SYSTEM}

10-1) There-is no method defined to lift the tie-down equipment for placement on the cask. Need rigging attachment points.

Response: See response to comment 1-7.

10-2) Item 17 does not fit inside item 26.

Response: Concur. Will revise drawing.

10-3) Parts 4 and 29 do not have lock pins as shown on the DSWC tie-down equipment so that torquing is not required to keep nut from coming off allows easier assembly. (See H-4-65160 ECN-A53412)

Response: OK, will incorporate lock pins to be consistent with WHC design.

10-4) See comment $6-5$ for parts 17,18 and 20.

Response: $O K$

10-5) All load bearing welds need mag. particle inspection.

Response: This is a new requirement, not presently included in the WHC specification for non-safety related handling equipment. The tiedown system is not safety-related since the cask can withstand drops if the tiedowns fail, therefore mag. particle inspection is not required. Should you wish to add this requirement, GA will provide a fixed price. 
WHC-SD-FF-DRR-00018

Rev. 0

\section{GENERAL COMMENTS}

11-1) WHC would like GA to reconsider the placement of the seals in the closure versus the cask body. As previously discussed, there are significant drawbacks to placing the seals in the cask body. One of the major disadvantages is that, if the required leaktight seal can not be achieved, WHC would have to unload the irradiated fuel from the cask in order to replace the seals.

Response: GA can provide the seals in the closure, using a double Helicoflex Theal, $^{2}$ with four socket head cap screws to hold the seal under the closure. This change would be at additional cost as discussed previously. GA will provide the price to WHC when it receives quotes from its suppliers.

11-2) Is there an over-pressurization limit for the ISC? Specifically, bounds that should be observed during evacuations and back-fills? Also, is there a time limit for the cask to be at a vacuum due to thermal concerns?

Response: See response to 1-6 for evacuation and back-fill requirements. Since the heat flow into the liner is fixed, its maximum temperature as well as the temperature of everything else outside of the CCC is unaffected if the cavity is a vacuum rather than gas-filled.

11-3) The report refers to MASF and the MASF Cask Loading Station (MCLS)in a number of places (e.g., pages 2.9-2, 6.1-1. 6.2-1, 6.3-1). Also, sheet 2 of drawing H-4-302134 refers to MASF. Rev. 3 of the ISC Spec. (WHC-S-4110) changed the location for loading the ISC from MASF to the RSB.

Response: See response to question 2.2.

\section{MEMORANDUM OF UNDERSTANDING RESPONSES}

12-1) An information sketch is provided that shows the desired cask configuration on the storage pad. Is the ISC thermally limited to the 5.5 foot minimum spacing or is this configuration feasible?

Response: We calculate that the proposed configuration will increase temperatures by approximately $5-10^{\circ} \mathrm{F}$. This is due partly to the restricted radiant heat transfer to the sky and partly to the increase in ambient temperature at the interior of the array. While the configuration is feasible in that temperatures would still be below allowable limits, we do not recommend it since margins

$$
\text { Helicoflex is a trademark of Le Carbone - Lorraine. }
$$




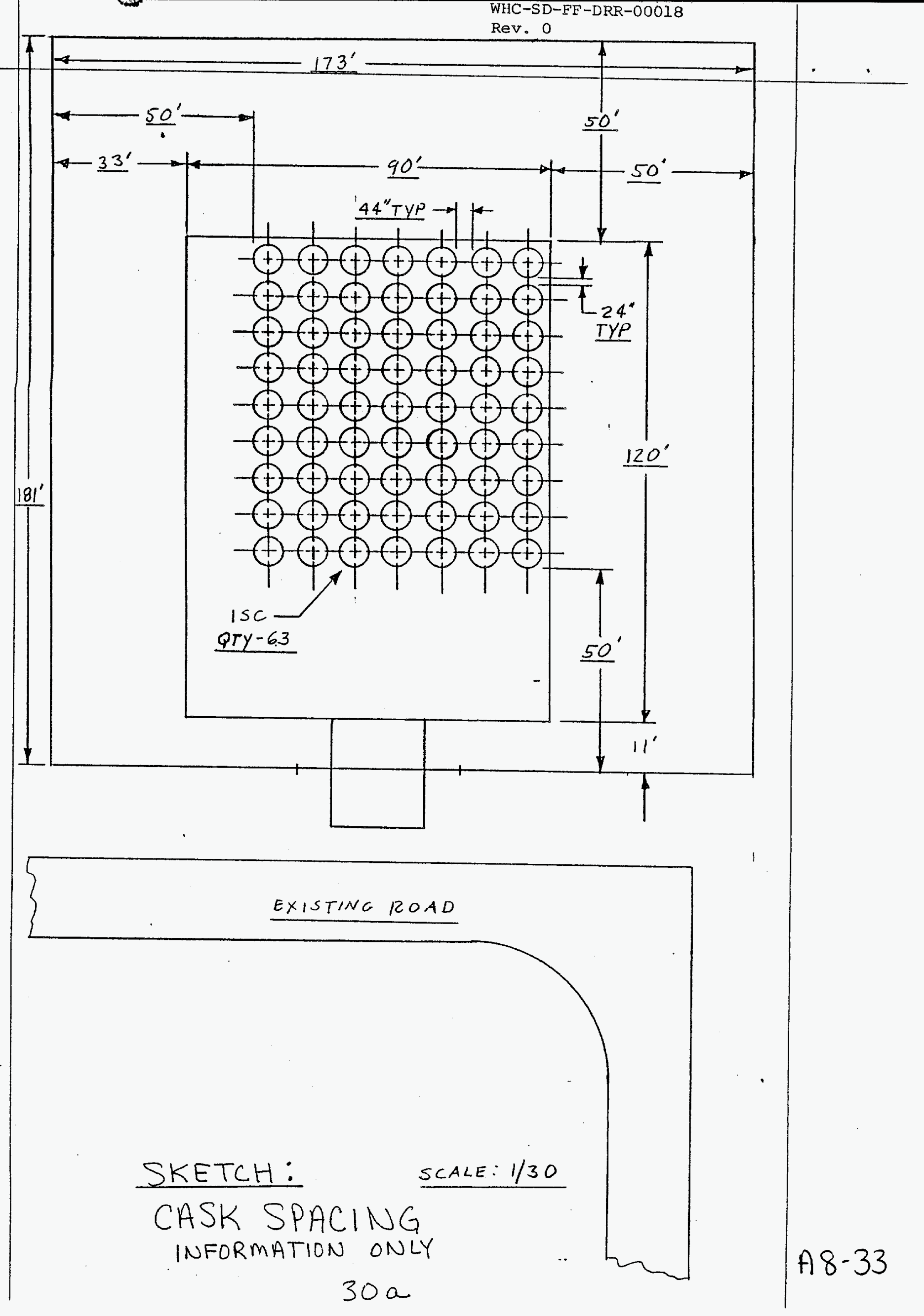


WHC-SD-FF-DRR-00018

Rev. 0

are decreased. For example, in case 2, off-normal severe hot conditions, the overall average concrete temperature could increase from $135^{\circ}$ to $145^{\circ} \mathrm{F}$, decreasing the margin from $15^{\circ}$ to $5^{\circ} \mathrm{F}$.

12-2) An information sketch is also provided that shows the discussed cask alignment feature. WHC realizes that there may be constraints in GA's design that WHC has not recognized and is open for further discussion of this feature.

Response: GA can provide the alignment feature. This change will increase the dose rate on the bottom of the cask to approximately $100 \mathrm{mrem} / \mathrm{h}$. If a drop onto the 6-inch centering post is considered an accident, the load limit shall be less than that shown in Section 3.5.7.3.3 of the DAR during a puncture drop (1,330 kips). This change would be at additional cost as discussed previously. GA will inform WHC of the added price after it receives quotes from its suppliers.

12-3) WHC requested GA to consider a flatness of 5 mils on the ISC upper O-ring seal plate.

Response: Even though the specification has no criteria (pressure, allowable leakage, etc.) regarding the seal interface, GA has two concerns with WHC's seal design. First, the WHC mating flange has an implied flatness of $.060 \mathrm{in}$. Thus, a flatness of $.005 \mathrm{in}$. for the GA mating surface will not ensure the surfaces are in close contact. Second, the Parker Handbook does not specify a flatness tolerance but relies instead on bolts to provide a uniform clamping force and contact between the mating surfaces. There is no uniform clamping force around the periphery in the WHC design.

For this type of application, GA suggests that WHC consider an inflatable seal which is commonly used to interface a cask with a facility loading port.

Notwithstanding the above, it is feasible to change the design to provide an improved flatness on the upper O-ring seal plate. Our supplier has recommended against a 5 mil flatness tolerance but is investigating a 10 and 15 mil flatness tolerance. GA will inform WHC of the added price after it receives quotes from its suppliers.

12-4) Closure Seal Test Port. WHC would like GA to consider a standard, straightthread O-ring fitting plug or quick-disconnect in lieu of the teflon sealed 1/4inch NPT plug.

Response: It is feasible to change this plug as desired. GA will inform WHC of the added price if any after it receives quotes from its suppliers. 


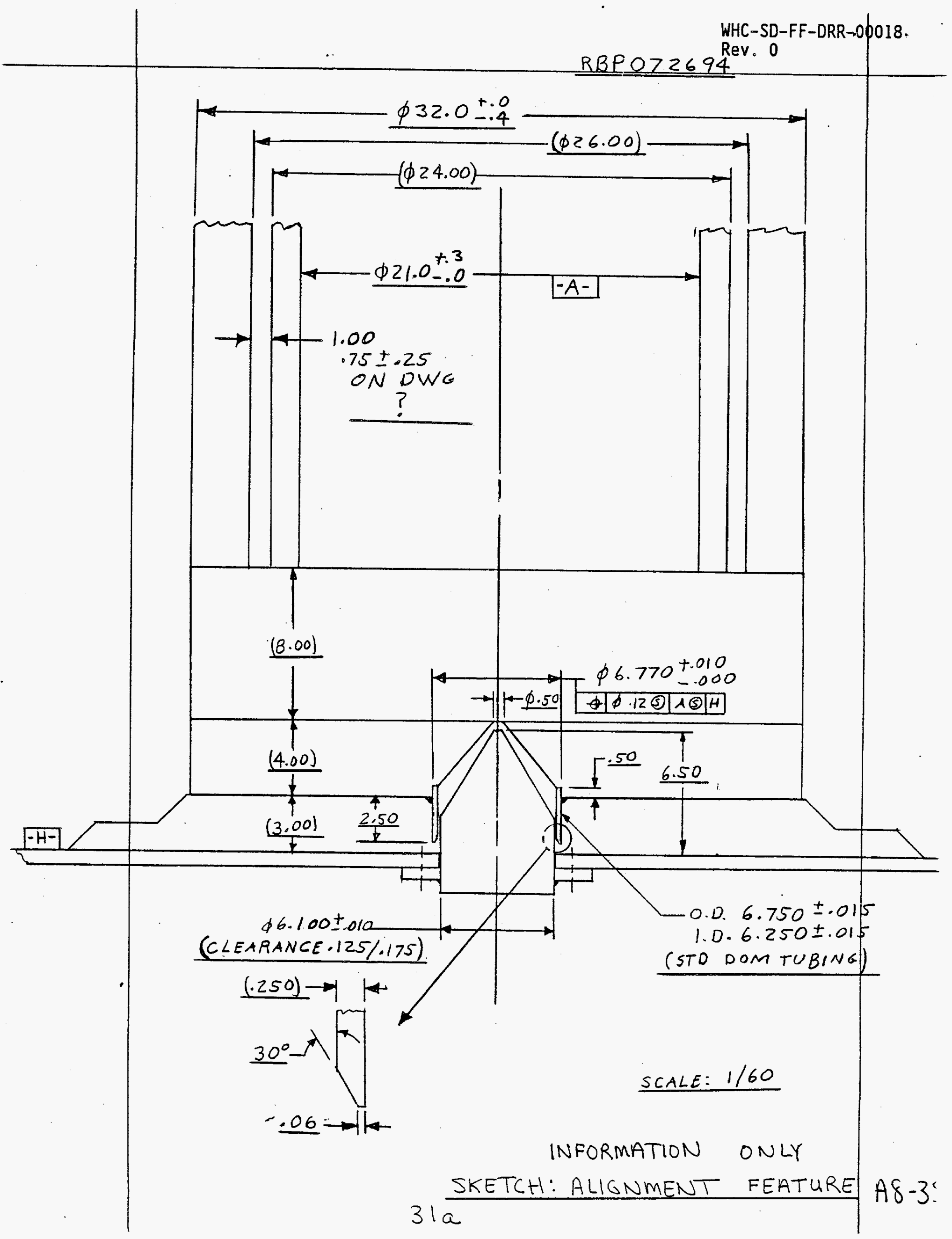




\begin{tabular}{|c|c|}
\hline Table 3.5 . & \\
\hline Spacing outer rebar curtain, SVRO & 4.0 \\
\hline Spacing inner rebar curtain SVRI & 8 \\
\hline Area vertical outer rebar curtain, AVRO & 0.79 \\
\hline Area vertical inner rebar curtain, AVRI & 0.44 \\
\hline $\begin{array}{l}\text { Area of inner shield section (60 sections), } \\
=\left(\mathrm{Pi} / 4^{*} \mathrm{NMR}\right)\left(\left(2^{*} R 3\right)^{\wedge} 2 \cdot\left(2^{*} R 4\right)^{\wedge} 2\right)\end{array}$ & 4.52 \\
\hline $\begin{array}{l}\text { Area of liner section (60 sections), } \\
=\left(\mathrm{Pi} / 4^{*} \mathrm{NMR}\right)\left(\left(2^{\star} R 5\right)^{\wedge} 2-\left(2^{\star} R 6\right)^{\wedge} 2\right)\end{array}$ & 1.72 \\
\hline Angle between rebar, $A O R$, radians, $=2^{*} \mathrm{Pi} / \mathrm{NOR}$ & 0.1 \\
\hline Constant, $A=e 2^{*} E s 1 / S N A$, tension & 1815.6 \\
\hline Constant, $\mathrm{B}=\mathrm{e} 1^{*} \mathrm{E} \mathrm{s} 1 / \mathrm{c}$, compression & 1815.6 \\
\hline$e=R 7-c$ & 5.9 \\
\hline $\begin{array}{l}\text { Outer rebar force (tension side of N.A.), } \\
=A V R O^{*}\left(15^{*} F y+2^{*} A^{*}\left(\left(R 1^{*} \cos \left(8^{*} A O R\right)+e\right)\right) \ldots+\left(R 1^{*} C\right.\right. \\
\left.\left.\left.\text { OS }\left(15^{*} A O R\right)+e\right)\right)\right)\end{array}$ & $1.22 E+06$ \\
\hline $\begin{array}{l}\text { Outer rebar force (compression side of N.A.), =- } \\
\text { AVRO }\left(B^{*}(R 1-e)+2^{*} B^{*}\left(\left(R 1^{*} \cos \left(9^{*} A O R\right)-\right.\right.\right. \\
\left.\text { e) }+\ldots . . .\left(R 1^{*} \cos \left(15^{*} A O R\right)-e\right)\right)\end{array}$ & $-8.71 E+05$ \\
\hline NIR, number of rebar in inner curtain & 20 \\
\hline NMR, number of pieces of middle and inner shells & 60 \\
\hline $\begin{array}{l}\text { Angle between middle shell pieces, AMR, } \\
=2^{*} \text { PiNMR }\end{array}$ & 0.10 \\
\hline Angle between inner shell sections, ACS, $=2$ & 0.10 \\
\hline Angle between inner rebar, AIR, radians, $=2^{*} \mathrm{Pi} / \mathrm{NIR}$ & 0.31 \\
\hline $\begin{array}{l}\text { Inner rebar curtain force (tension side of neutral } \\
\text { axis }=A V R I^{*}\left(2^{*} A^{*}\left(\left(R 2^{*} \cos \left(.5^{*} A \mid R\right)+e\right)+\ldots \ldots+\right.\right. \\
\left.\left.\left(R 2^{*} \cos \left(4.5^{*} A \mid R\right)+e\right)\right)\right)\end{array}$ & $1.43 E+05$ \\
\hline $\begin{array}{l}\text { Inner rebar curtain force compression side of N.A. = } \\
\text {-AVRI* }\left(2^{*} B^{*}\left(\left(R 2^{*} \cos \left(.5^{*} A \mid R\right)-\right.\right.\right. \\
\left.\left.\text { e) }+\ldots .+\left(R 2^{*} \cos \left(4.5^{*} A I R\right)-e\right)\right)\right)\end{array}$ & $-5.74 E+04$ \\
\hline $\begin{array}{l}\text { Inner shield force (tension side of N.A. }= \\
\text { AMS* }\left(2^{*} A^{*}\left(\left(R 8^{*} \cos \left(.5^{*} A M R\right)+e\right)+\ldots .+\left(R 8^{*} \cos (14.5\right.\right.\right. \\
\left.\left.\left.\left.{ }^{*} A M R\right)+e\right)\right)\right)\end{array}$ & $3.75 E+06$ \\
\hline $\begin{array}{l}\text { Inner shield force (compression side of N.A. = } \\
\text { AMS }^{*}\left(2^{*} B^{*}\left(\left(R 8^{*} \cos \left(.5^{*} A M R\right)-\right.\right.\right. \\
\left.\left.\text { e) }+\ldots+\left(R 8^{*} \cos \left(14.5^{*} \text { AMR }\right)-e\right)\right)\right)\end{array}$ & $-8.40 E+05$ \\
\hline $\begin{array}{l}\text { Liner force (tensio }- \text { ide of N.A. }= \\
A C S^{*}\left(2^{*} A^{*}\left(\left(R 9^{*} \cos \left(.5^{*} A C R\right)+e\right)+\ldots .+\left(R 9^{*} \cos \left(14.5^{*}\right.\right.\right.\right. \\
A C R)+e)))\end{array}$ & $1.23 E+06$ \\
\hline $\begin{array}{l}\text { Liner force (compression side of N.A. = } \\
A C S^{*}\left(2^{*} B^{*}\left(\left(R 9^{*} \cos \left(.5^{*} A C R\right)-\right.\right.\right. \\
\left.\left.\text { e) }+\ldots .+\left(R 9^{*} \cos \left(14.5^{*} A C R\right)-e\right)\right)\right)\end{array}$ & $-1.21 E+05$ \\
\hline
\end{tabular}




\section{APPENDIX A}

\subsection{OPERATIONS}

The following operations are typical of spent fuel storage casks. Every utility modifies the procedures depending on the site safety requirements and the fuel characteristics. WHC shall modify these operations accordingly based on the FFTF fuel characteristics and WHC safety requirements.

\subsubsection{Closure Installation. Refer to Figure 1.3-1}

1. While the ISC is stationed at the Cask Loading Station and prior to configuring the ISC to the DSWC Floor and Cover Assembly:

1.a Install (two) closure guide pins with an anti-seize lubricant, taking care not to damage the cask sealing surface.

1.b Clean seal surfaces until free of dust and debris. Install new flange seals.

1.c Install the DSWC Floor valve and Cover Assembly per facility procedures.

2. After the ISC has been loaded with a CCC and while it is still configured to DSWC floor Valve and Cover Assembly:

2.a Place dessicant in dessicant canister and attach canister to closure with nut. Clean and inspect closure seal surfaces.

2.b Attach closure to DSWC Plug Handling Equipment, H4-65153, item 4. Set closure assembly on DSWC floor valve.

2.c Using the normal RSB-CLS operating procedures, lower closure onto the ISC and closure guide pins.

3. After closure placement, remove DSWC Floor Valve per facility operating procedures.

4. Remove closure guide pins.

5. Install bolts with an anti-seize lubricant.

6. Torque bolts to $1500 \mathrm{ft}-\mathrm{lb}$. 
WHC-SD-FF-DRR-00018

Rev. 0

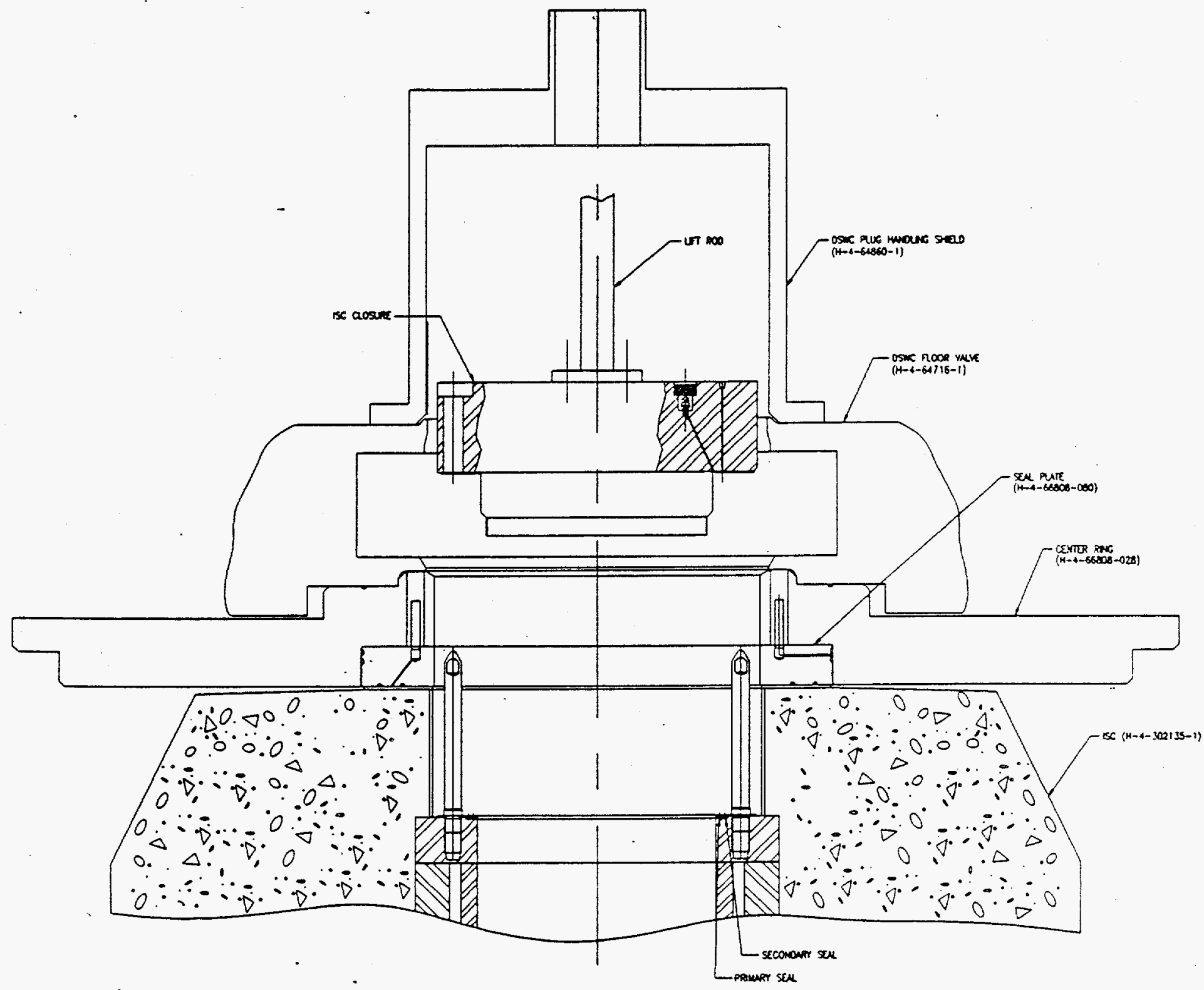

Fig. $1.3^{-1}$ closure InStallation 
WHC-SD-FF-DRR-00018.

Rev. 0

7. Leak Test Closure per Section 1.3.3.

\subsubsection{Closure removal.}

1. Remove the two port covers on closure and sample cask internal atmosphere per steps 1 to 5 of the cavity sampling procedure.

2. If there is no leak in the CCC connect ISC to inert gas supply (if desired) at atmospheric pressure.

3. Loosen and remove closure bolts. This can be done either by personnel or remotely.

4. Attach closure to DSWC Plug Handling Equipment, H4-65153, item 4 and install Cover assembly and DSWC Floor Valve per facility operating procedures. (See figure for closure installation.)

5. Remove closure per facility operating procedures.

\subsubsection{Leakage Testing.}

1. Install closure (see closure installation, above).

2. Attach female half of a 0.25 in. Snaptite fitting to ISC male half. Evacuate ISC to $0.05 \mathrm{~atm}$ or less and fill with helium to $1 \mathrm{~atm}$.

3. Disengage female half of Snaptite fitting .

4. Connect leak testing equipment (helium mass spectrometer) to leak testing port that connects to annulus between inner and outer helicoflex seals. Evacuate annulus to $0.01 \mathrm{~atm}$ or less.

5. Measure helium leakage rate. The ISC maximum permissible leakage rate shall be leaktight as defined in the American National Standard for Leakage Tests on Packages of Shipment of Radioactive Materials, ANSI N14.5. Leaktight is less than $1 \times 10^{-7} \mathrm{std}-\mathrm{cm}^{3} / \mathrm{s}$ air $\left(1.96 \times 10^{-7} \mathrm{~cm}^{3} / \mathrm{s}\right.$ helium $)$. The test procedure must have a minimum sensitivity of $5 \times 10^{-8} \mathrm{std}-\mathrm{cm}^{3} / \mathrm{s}$ (air). 
Argon may be used instead of helium if appropriate mass spectrometer and test procedures are used.

\subsubsection{Cavity Sampling.}

Cavity sampling is typically performed inside a decontamination area, hot cell or confinement building where any potential release can be controlled.

1. Cutoff upper port closure. This can be done using a carbon arc air gouger, plasma cutter, portable lathe, etc.

2. - Cutoff lower port closure. Using same method as above.

3. Determine if there is leakage through the port (Snaptite fitting) by using a sniffer. If a leak is found, go to step 5.

4. Attach female half of a 0.25 in. Snaptite fitting to ISC male half. Sample cask internal atmosphere to determine if there is a leak in the CCC.

5. Follow site procedures to deal with CCC leak.

\subsubsection{Welding of Port Closure.}

1. Install lower port cover plate over port. Weld and inspect per H-4-302135 requirements.

2. Install upper port cover plate. Weld and inspect per H-4-302135 requirements.

\subsubsection{Lifting.}

1. Fully screw the three lugs, using an anti-seize lubricant, into the anchors located in the top of the cask, located on a $62.0 \mathrm{in}$. diameter circle. Back out each lug $180^{\circ}$ maximum, such that the 1.75 in. thick plate is inline with the ISC centerline.

2. Attach the cask lifting assembly, H-4-65150, item A2 (without items 10 through 13), to the lugs, using the $1.5 \mathrm{in}$. diameter bolts and nuts (H-4-65150, items 14 and 15). 
3. Lift ISC.

\subsubsection{Installation on Trailer.}

1. Place cask on trailer.

2. Remove the three ISC lifting lugs; store properly for reuse.

3. Set the tiedown fixture on top of the ISC; align with the trailer tie down lugs.

4. Install the four tiedowns.

5. Tighten tiedowns equally using the ratchets in progressive sequence.

[Response to comment, not to be included in text: Will provide sketch of tiedown assembly at ISC installation.

As noted in note 5 of DWG $\mathrm{H}-4-302136$, ratchet binders are torqued to an approximate preload of $200 \mathrm{ft}-\mathrm{lb}$. This is based on ratchet binder manufacturer's recommended torque to remove slack in the tie down linkage. Per manufacturer's test, this torque results in approximately 5-10 kips of load in a typical tie down strut. Section 6.0 stress calcs have adequate margin and conservatism to account for this nominal pre load.]

\subsubsection{Off Loading the Trailer.}

1. Loosen tiedowns equally using the ratchets in progressive sequence.

2. Remove the four tiedowns and store properly for reuse.

3. Remove the tiedown fixture from the ISC and store properly for reuse.

4. Lift ISC following the instructions provided in paragraph 1.2.4, Lifting.

\subsubsection{Cover Installation.}

1. Lift cover using center eyebolt.

2. Install cover with holes in line with ISC lifting anchors. 
WHC-SD-FF-DRR-00018

Rev. 0

3. Bolt cover to ISC with 1.75-5 UNC-2A cover bolts and washers, using an antiseize lubricant.

4. Thread wires through two cover bolt to nearby holes in the cover; crimp wires with tamper indicating seals. 
WHC-SD-FF-DRR-0,0018

Rev。 0

Appendix B

\section{Dynamic Amplification Factor}

The dynamic load factor (DLF, also referred to as a dynamic amplification factor DAF) is the ratio of the dynamic deflection at any time to the deflection which would have resulted from the static application of the load (Ref. Biggs, Section 2.2d, p39). In general, the time dependency is unimportant and the DLF is simply defined as the ratio of the maximum dynamic deflection to the deflection from a statically applied load.

The DLF can be computed by representing the structure as a spring-mass system (with or without damping) and numerically integrating to determine the time history of the motion due the dynamically applied load. However, defining the damping for a spring-mass system is very subjective and using numerical integration to determine the motion of a large spring-mass system is expensive. Fortunately for most problems (e.g., the dynamic impact of a cask or the seismic response of a building), virtually all of the dynamic amplification is due to the response of the first fundamental mode of the system, which means that the analysis can be reduced to a one degree-offreedom modal analysis.

To do this type of analysis, the structure (e.g., cask or building) is represented by a one degree-of-freedom spring-mass system (with or without damping), where the mass and stiffness are the generalized mass stiffness of the first fundament mode of the system. If damping is included, the generalized damping is computed as follows:

$$
C=2 \zeta(K M)^{0.5}
$$

where

$\zeta=$ percent critical damping for the first mode

$\mathrm{K}=$ generalized stiffness

$M=$ generalized mass

The percent critical damping is determined from test and is a function of the type of structure (e.g., welded steel, reinforced concrete, wood, etc.) and the level of loading in the structure (e.g., very small defections or defections approaching yield loads). In general, the larger the deflections, the greater the damping; particularly for reinforced concrete structures where micro-cracking of thconcrete and motion (friction) between the concrete and steel occur. Note that the damping is a function of the deformation of the structure and not of what caused the deformation. 
The response of the system is them computed by solving the following differential equation:

$$
F(t)=M a(t)+C v(t)+K x(t)
$$

where

$F(t)=$ force time history (e.g., seismic or impulse (impact) time history) $a(t)=$ acceleration time history

$v(t)=$ velocity time history

$x(t)=$ displacement time history

GA computed the DLF using the modal response procedure described above. We selected the damping value from UCRL-15910 because these data are for deformations similar to those that would occur during a cask drop and are a result of many years of study (the references go back to 1978) and were selected by some of the nations leading experts in structural damping (i.e., Robert Kennedy and Steven Short).

This approach is very conservative since it ignores the energy dissipated as the initial shock waves from the impact resonate through the cask and only accounts for the energy dissipated due to the vibration of the cask's first natural frequency. Test data from NAC-LWT cask drop tests demonstrated the conservatism of this approach since the measured DLF was much less than the calculated DLF (The measured data showed a DLF essentially equal to 1.0 versus a calculated value of almost 2.0 ). 


\section{APPENDIX D \\ CONCRETE TEMPERATURE ALLOWABLES}

GA analyzed the ISC more conservatively than has been done for other NRC licensed casks, meeting the requirements of 10CFR72.122(b)(2)(i).

For normal, long-term conditions GA conservatively uses the maximum temperature day (average temperature $=94^{\circ} \mathrm{F}$ ) given in the WHC specification and uses the provided average wind speed and solar load. This is conservative because in the NRC-licensed casks' Safety Analyses Reports (SAR), a temperature of $75^{\circ} \mathrm{F}$ is used to bound most average temperatures across the United States. In addition, no solar load is used. Our analysis is further conservative because the convective heat transfer coefficient used in the calculations for the licensed casks is higher than the value calculated from the wind speed given by the WHC specification.

Fluctuations about this condition are bounded by the severe ambient case were evaluate as off-normal situation. For this we used the maximum temperature day in the WHC specification, without wind, and with solar loads. Our analysis is extremely conservative in that the NRC licensed casks use for this case a convective heat transfer coefficient higher than the value calculated from the wind speed given by the WHC specification.

ACI-349 allows temperatures higher than $150^{\circ} \mathrm{F}$ in localized areas, up to $200^{\circ} \mathrm{F}$. At these temperatures, no structural degradation of the concrete is expected. As shown in the following pages (excerpts of the safety analysis report for the Ventilated Storage Cask (VSC)) the NRC licensed this cask with concrete temperatures much higher than those for the ISC cask during the accident condition of ashfall and plugged ducts. The VSC license allows the inner concrete surface to be $225^{\circ} \mathrm{F}$ where as the ISC temperature is only $177^{\circ}$.

Attached are also excerpts of the NUHOMS Safety Analysis Report (Appendix D). This other cask was also licensed by the NRC with operating temperatures higher than those in the ISC cask with blocked ducts. This appendix discusses different references that show that concrete properties at $200^{\circ} \mathrm{F}$ are essentially the same as at $150^{\circ} \mathrm{F}$.

Therefore, the allowables used in this report meet the ACI-349 requirements. 
WHC-SD-FF-DRR-00018

Rev. 0

$910683 \mathrm{~N} / \mathrm{C}$

PSN.91-001

Revision 0A

SAFETY ANALYSIS REPORT

FOR THE

VENTILATED STORAGE CASK SYSTEM

Prepared by:

\section{PACIFIC SIERRA NUCLEAR ASSOCLATES AND \\ SIERRA NUCLEAR CORPORATION SCOTTS VALLEY, CALIFORNIA}

December 1993

$D-2$

$A 8-46$ 
WHC-SD-FF-DRR-00018

Rev. 0

\subsection{THERMAL EYALUATION}

\section{1 \\ DISCUSSION}

This section presents the thermal analysis of the VSC system for normal operation. The significant thermal design feature of the VSC system is the air flow path used to remove the $24 \mathrm{kw}$ (maximum) of decay heat. This antural circulation of air inside the VCC allows the concrete temperatures to be maintained below the design limits and keeps the fuel cladding temperatures below limits where damage might cocur.

The base calculation was performed asuming $75 \%$ ambient conditions to model the average long term temperatures expected over the life of the cask No solar bad was used bere because the exclusion of solar loads for this case gives a more severe temperature gradient through the concrete wall and, hence, represents a worse case normal operating thermal stress condition. Aiso, as shown in Figure 4.1-1, recent cask tests have shown little or no impact of solar load on fuel temperatures (43). Even if solar loads are assumed to affect the cask for 12 to 14 day-light bours they will only modestly affect the outer concrete temperatures for the period the sun is shining. The temperatures of the bulk of the concrete and the MSB will never see the transient effects This is further discussed in Section 112

To bound the expected temperature ranges in which the VSC system might operate two off-normal severe environmental temperature conditions were evaluated. These calculations are presented in detail in Section 11.1 (Off-Normal Events). The cases considered are $40^{\circ} \mathrm{F}$ with no solar bads and $100^{\circ} \mathrm{F}$ with maximum solar bads. The maximum solar load was calculated to be the 24hour average solar load (from 10CFR71) so as to more accurately model the steady state temperature expected from long term (four to five days) exposure to $1000 \mathrm{~F}$ air. Inclusion of any solar bads in this calculation is considered to be conservative based on the findings of recent cask tests at INEL which show essentially no solar effect on cask or fuel temperatures (see Figure 4.1-1) (4.1).

The $75^{\circ} \mathrm{F}$ ambient conditions are utilized to determine long term storage temperatures, and the -40 and $100^{\circ} \mathrm{F}$ ambient temperatures are used to model extreme environmental conditions. In addition to these three cases, three thermal analyses of offnormal and accident conditions are presented in Section 11.0. The first off-nomal case considers a $125^{\circ} \mathrm{F}$ ambient condition with maximum solar loads and a maximum decay heat payload. This condition is analyzed to show the temperature for the worse case heat load that due to decay of the heat source, could only happen once over the life of the cask The next off-normal condition considers blockage of the air inlets on one side of the cask (one-half of the inlets). The final analysis, an accident condition, considers the complete blockage of all air inlets.

Although the cask has been analyzed for an average long term temperature of $75^{\circ} \mathrm{F}$, higher average long term temperatures could easily be accommodated. The limiting general/ocal concrete temperature $\left(150 / 225^{\circ} \mathrm{F}\right)$ is not reached even at an average long term temperature of $100^{\circ} \mathrm{F}$. Since this average long term temperature is not exceeded anywhere in the United States, the ambient temperature requirement is met at any site. Also, the maximum 

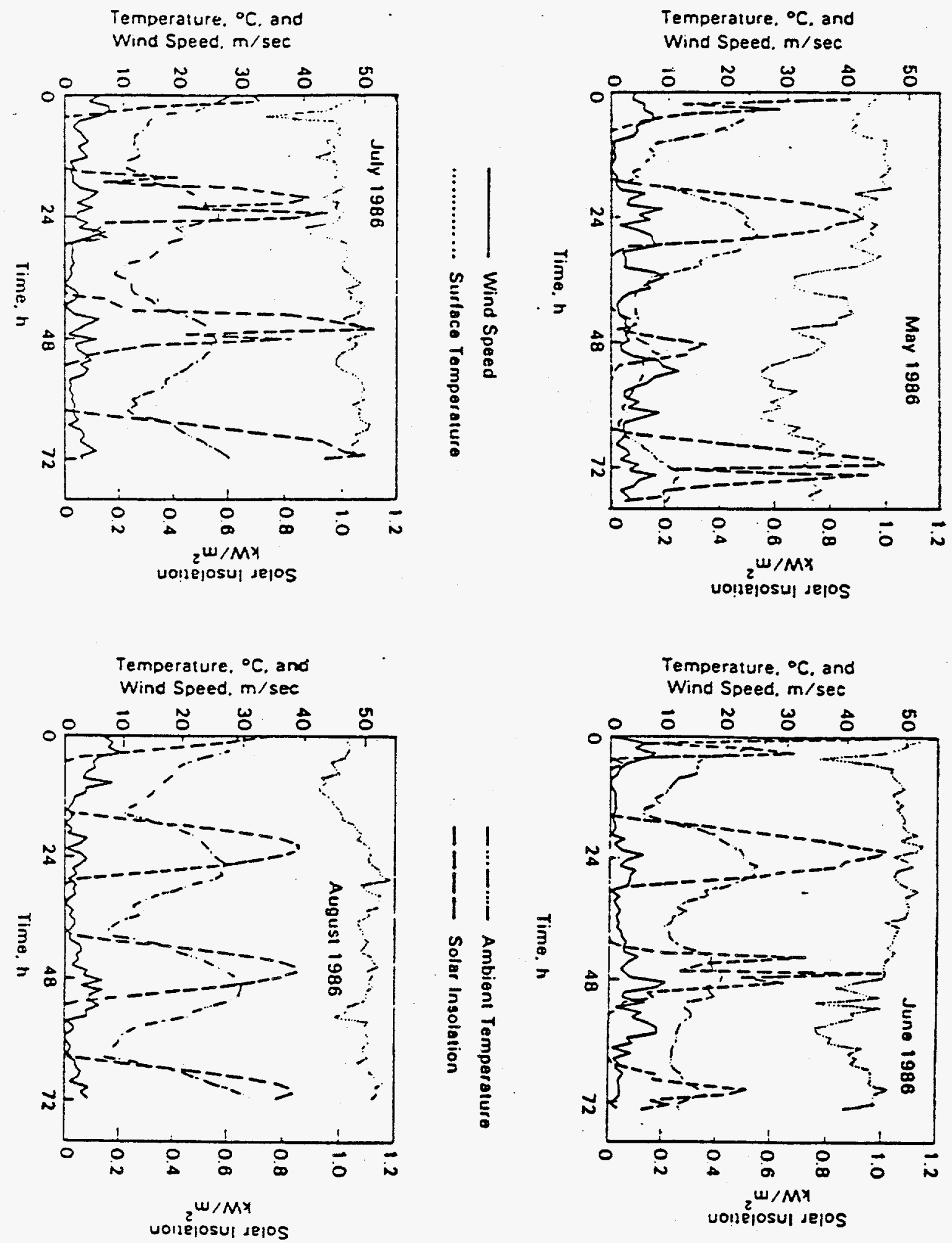

uonéosul delos

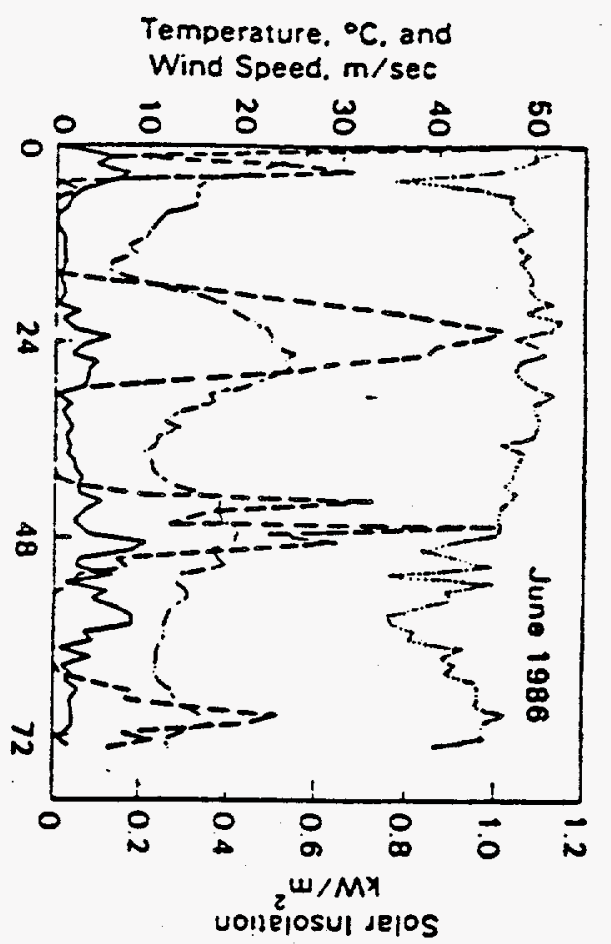


WHC-SD-FF-DRR-00018

Rev。O

temperature for the 50 percent probability level (two year recurrence) less than $125^{\circ} \mathrm{F}$, which has been analyzed, does not restrict the use of the VSC system at any U.S. site.

Table 4.1-1 summarizes the results of the thermal calculations. As can be seen from this table, the conservatively calculated temperatures are below the temperature specifications listed in sections 20 and 4.3.

\section{SUMMARY OF THERMAL PROPERTIES OF MATERIALS}

The thermal properties used in the thermal bydraulic analyses are shown in Table 4.2-1. The derived parameters (effective conductivities) are discussed in Section 4.4. Temperature invariant properties were used for the concrete, steel, fuel, and helium. Low values derived from the open literature and conservative calculations were used. If temperature dependent properties (especially for concrete and fuel) were used, the maximum temperatures reported in this section would be slightly reduced.

\subsection{TECHNICAL SPECIFICATION OF COMPONENTS}

Temperature limits were established for all the materials used in the VSC system. Specifically, these limits are for concrete, fuel cladding, steel, RX-277 and coatings. The limits were established in accordance with the following codes, standards, and manufacturers recommendations in order of precedence:

\section{Code or Standard}

ASME Section III Division I

ACI 349 and NRC Guidance

ANS 57.9

ASTM

Manufacturers Recommendations

\section{Component}

Steel

Concrete

Steel and Concrete

Steel and Concrete

Coatings

Based upon evaluation of these limits it was determined that the fuel cladding and concrete temperature limits were the limiting conditions (steel temperatures well above $1000^{\circ} \mathrm{F}$ and coating temperatures up to $1300^{\circ} \mathrm{F}$ being acceptable).

The normal, long-term (weeks to months) limits for concrete were established as $150^{\circ} \mathrm{F}$ generally and $225^{\circ} \mathrm{F}$ locally. Tab!e $43-1$ presents more details on the long-term and short-term temperature limits for the concrete. This table is based on ACI-349, Appendix A and NRC guidance.

The fuel cladding temperature limit is actually a complex function of temperature versus time, and internal rod pressurization (4.1). As such, it should be calculated in accordanc ith the methodology presented in Appendix 7 (4.1) for each specific site. As this appendix shows the allowables range from $712^{\circ} \mathrm{F}$ to $752^{\circ} \mathrm{F}$ depending on fuel type. The $712^{\circ} \mathrm{F}$ could be used for all sites on a generic basis witbout further evaluation $A$ shortterm (days) limit of $1058^{\circ} \mathrm{F}$ was established for the vacuum drying, transfer and other short term off-normal and accident conditions. This temperature was establisbed based on experimental results for high temperature induced failure of Zircaloy 
WHC-SD-FF-DRR-00018

Rev. 0

TABLE \&1-1

SUMMARY OF VSC SYSTEM

THERMAL HYDRAULICS EVALUATION

\section{SUMMARY OF LONG TERM \\ VSC SYSTEM THERMAL HYDRAULIC EVALUATION}

\section{CASE}

Generic Limits

Steady State

Normal-Long

Term Storige

Steady State

Severe Cold

Steady State

Severe Hot

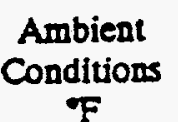

$F$

N/A

75

$-40$

100
Air Solar

N/A

no

164

85

30

no

yes

193

135

.32

45

220

299
$\operatorname{Max}$

Clad

712

688

598

708

SUMMARY OF SHORT TERM

VSC SYSTEM THERMAL HYDRAULIC EVALUATION

Generic Limits

N/A

N/A N/A

200

350

N/A

1058

12 hour Maximum

125

yes

222

187

255

325

730

Thermal Load Transient

$1 / 2$ of Inlets Bloctred

75

no

173

86

194

279

692

All Inlets Blocked

75

no 22

87

201

293

703

MSB in MTC

with $\mathrm{He}$

75

N/A N/A N/A

N/A

463

848

with vacuum

75

N/A N/A

N/A

N/A

463

882 
WHC-SD-FF-DRR-00018

Rev. 0

\section{APPENDIX D \\ A REVIEH OF CONCRETE BEHAVIOR \\ UNDER SUSTAINED ELEVATED TEMPERATURES}

D. 0

Revision 1

$$
A 8-51
$$


WHC-SD-FF-DRR-00018

Rev. 0

D.1 Review of Concrete Behavior Under Sustained Elevated Temperatures

The effects of elevated short and long term temperatures on concrete structures have been a subject of much research in the U.S.A. and european communities, and findings of these studies and tests are reported in a number of publications. A number of these publications and test reports, particularly those in references $D .1$ through $D .10$ were searched for characteristics of concrete under sustained elevated temperatures. Concrete characteristics as it relates to its physical/chemical reactions and subsequent effect on the mechanical properties are established and are documented herewith.

Changes in concrete properties under elevated temperatures and under atmospheric pressure are primarily attributable to the loss of free water. In ordinary saturated concrete 28 to 107 of its volume is occupied by evaporable free water. Upon heating, a portion or all of this water could be removed. Lankard et al. (D.4) identified five types of evaporable water which differ in the degree of attraction to the solid materials present as follows:

1. Water in capillary pores

2. Water in gel pores

3. Water adsorbed on crystal surfaces

4. Adsorbed water confined between adjacent crystal surfaces

5. Zeolitic intracrystalline water

When concrete is subjected to elevated temperatures the free water would be removed in approximately the order listsd above, i.e., capillary and large pore water would be the first to come off, gel waters next and so on. At a temperature of $175^{\circ} \mathrm{F}$ some of the capillary water will be lost, however, hydration of cement will continue. R. D. Allen (D.5) reports that the capillary water is evaporated and released by heating to $100^{\circ} \mathrm{C}\left(212^{\circ} \mathrm{F}\right)$. However the loss of adsorbed water occurs over a broader temperature range, with all evaporable water having driven off by $300^{\circ} \mathrm{C}\left(572^{\circ} \mathrm{F}\right)$. At this temperature changes are seen in the microstructures.

Degradation or deterioration of concrete as it relates to greater crack formation and subsequent spalling is generally attributed to the loss of chemically combined or nonevaporable water. Lankard et al., reports that the results of tests on unsealed concrete specimens indicate: "An increase in chemically combined water content of the cement phase at $175^{\circ} \mathrm{F}$ and $10,20,40$ percent loss of this water at 250,375 , and $500^{\circ} \mathrm{F}$ respectively." The loss of chemically combined water. will cause dehydration of concrete. $R$. D. Allen concludes that the principle dehydration reactions are:

1. Decomposition of cement gel into dicalcium silicate, beta wallastanite and water,

NUH -003

D. 1-1

Revision 1

$A 8-52$ 
WHC-SD-FF-DRR-00018

Rev. 0

2. decomposition of calcium hydroxide into lime and water.

The actual effect of this dehydration reaction is weakening of the bond between cement gel phases, which in turn affects its mechanical strength, and may cause microcrack formation and shrinkage of the cement. It is interesting to note that these dehydration reactions with reduced strength phases are reversible if water is reintroduced into the concrete.

From the above observation and given the fact that the NUHOMS HSM concrete will not reach temperatures beyond $186^{\circ} \mathrm{F}$ for the maximum summer average ambient temperature of $100^{\circ} \mathrm{F}$, it can be concluded that no adverse effect as it relates to degradation or deterioration of concrete can be anticipated under normal storage conditions. The adequacy of the BSM concrete is further substantiated by the fact that the maximum concrete temperature of $150^{\circ} \mathrm{F}$ for the lifetime average ambient temperature of $70^{\circ} \mathrm{F}$ is within the ACI 349-85 Code, Paragraph A.4.1 long term temperature, IImit of $150^{\circ} \mathrm{F}$. Indeed, the maximum HSM concrete temperatures for the $100^{\circ} \mathrm{F}$ ambient temperature case are below the $150^{\circ} \mathrm{F}$ temperature limit at all module locations except the local areas near the center of the roof and floor slabs which are well within the ACI 349-85 Code, Paragraph A.4.1 local temperature limit of $200^{\circ} \mathrm{F}$.

The physical changes, i.e., loss of evaporable water, and also the chemical changes, $i . e .$, dehydration and formation of other hydrated cemert phase associated with loss of nonevaporable or chemically combined water, at sustained elevated temperatures will effect concrete mechanical properties. Mechanical properties most affected by elevated temperatures are compressive strength, modulus of elasticities, tensile strength, poisson ratio and creep. As stated earlier, in recent years extensive amounts of test on concrete mechanical properties at elevated short and long term temperatures have been performed and published. The results of the majority of these tests indicate that compressive strength of sample specimens heated up to (and occasionally above) $250^{\circ} \mathrm{F}$ and exposed to ambient humidities have changed very little, and frequently exhibit an increase in strength when compared to similar samples stored at room temperature.

Based on the results of tests performed, $V . V$. Bertero and $M$. Polvika (D.6) report that: "If the free moisture is allowed to escape during heating to $300^{\circ} \mathrm{F}$, the mechanical characteristics of the concrete are very little affected by the heat treatnent. This is true regardless of the number of cycles or duration of the thermal treatment." other tests which include long term effects have also indicated a simliar conclusion. $K$. W. Nasser (D.7) concludes from the results of tests performed on 500 specimens at temperature range from $70^{\circ} \mathrm{F}$ to $205^{\circ} \mathrm{F}$, that the gain in strength beyond the age of 14 days is independent of temperature range of 70 to $205^{\circ} \mathrm{F}$. The duration of this test was one year. The result of this test is presented in Figure D.1-1. In another test performed

NUH -003

D. 1-2

Revision 1 


$$
\begin{aligned}
& \text { WHC-SD-FF-DRR-00018 } 910683 \mathrm{~N} / \mathrm{C} \\
& \text { Rev. } 0
\end{aligned}
$$

by Construction Technology Laboratories, Portland Cement Association (D.8) on Hanford concrete, specimens were tested at temperatures of $250^{\circ} \mathrm{F}, 350^{\circ} \mathrm{F}$ and $450^{\circ} \mathrm{F}$ for durations as long as 920 days. The results of these tests further verify the above conclusion. It is interesting to note that even at $450 \circ \mathrm{F}$ the concrete compressive strength did not fall below the original mix designs of 4,500 psi and $3,500 \mathrm{psi}$. The results of this particular test are presented in Figure D.1-2.

In general, the increase in compressive strength at moderate elevated temperatures (below $250^{\circ} \mathrm{F}$ ) is attributable to the removal of the evaporable water. Other tests performed by H. S. Abrams $(D .3)$, A. Weber et al. (D.10), Ranazu at al. (D.9) and a number of other tests have all indicated sinilar flndings that the concrete compressive strength is very little effected by elevated temperatures up to $250^{\circ} \mathrm{F}$. At temperatures above $250^{\circ} \mathrm{F}$ concrete begins to loose some strength. This is attributed to the chemical changes, i.e., dehydration, that occurs in the cement phase as described earlier.

For the purpose of design, the NUEOMS HSM concrete strength is very conservatively reduced by $10 \%$ at $500 \cdot \mathrm{F}$ for all normal, offnormal, and accident load combinations. This reduction is based on the curves presented by Hark Fintel (D.2) as shown in Figure $0.1-3$. Other mechanical properties that are affected by elevated concrete temperatures are tensile strength and podulus of elasticity. Since the design of NUHOMS does not rely on the tensile strength of concrete due to the use of reinforcement, any loss of this strength under elevated temperatures does not affect the NuHOMs design. The reinforcing bar tensile strength, however, is conservatively selected at $500^{\circ} \mathrm{F}$ for the $125^{\circ} \mathrm{F}$ off-normal, and accident load combinations.

The modulus of elasticity also decreases with the increased temperature of concrete. Again, the loss of water explains the reduction in modulus of elasticity. According to Lankard, the absence of free water in heated concrete means that in essence an incompressible phase has been removed and the closer approach due to application of an external stress of solid surfaces formally contacting the same volume of water is to be expected. As shown in Figure D.1-4 the 1088 in the modulus of elasticity due to elevated temperatures up to $200^{\circ} \mathrm{F}$ is expected to be approximately 10 t $^{\circ}$ of the original value. The modules of elasticity determines the flexural rigidity of the structure, and at the same time affects the magnitude of the thermal stresses induced under constrained conditions. A substantial reduction in this property will cause excessive flexural deformation in long span beams. Since the NUHOMS walls and roof slabs are deep, short span members, the added deflections in these members under iot 1058 of modulus of elasticity is considered negligible.

NuHoms ${ }^{\top}$ is a trademark of Pacific Nuclear.

NUT -003

D. 1-3

Revision 1

$$
D-10
$$


WHC-SD-FF-DRR-00018

Rev. 0

other mechanical properties such as creep and Poisson ratio are also considered and their effects under elevated temperatures investigated and found to have insignificant impact on the design of the NUHOKS modules. Although the loss in the concrete's modulus of elasticity reduces the thermal stresses, this loss is not considered in the design of HSMs for sake of conservatism.

In conclusion, given the maximum concrete design temperatures of the NUHOMS ${ }^{\circ}$ HSM i.e., $150^{\circ} \mathrm{F}$ for the $70^{\circ} \mathrm{F}$ lifetime normal ambient case and less than $200^{\circ} \mathrm{F}$ for the maximum normal summer ambient case of $100^{\circ} \mathrm{F}$, the concrete integrity is unaffected and is in compliance with the ACI 349-85 Code. In addition, the maximum HSM concrete temperature of $222^{\circ} \mathrm{F}$ for the $125^{\circ} \mathrm{F}$ short term extreme ambient temperature case are well within the ACI 349-85 Code, Paragraph A.4.2 short term temperature of $350^{\circ} \mathrm{F}$. The same can be said for the worst case accident condition with the HSY vents assumed to be blocked with an extreme ambient temperature of $125^{\circ} \mathrm{F}$ for which the maximum HSM concrete temperatures are less than $350^{\circ} \mathrm{F}$, except at localized areas near the center of the roof, wall, and floor slab. At these locations the maximum concrete tenperatures are $441^{\circ} \mathrm{F}$, $414^{\circ} \mathrm{F}$, and $479^{\circ} \mathrm{F}$ respectively, which are well below the ACI 349-85 Code, Paragraph A.4.2 short term local temperature limit of $650^{\circ} \mathrm{F}$. It is also noted that the average temperatures through the thickness of the roof and loor slabs are less than $350^{\circ} \mathrm{F}$ for this worst case. Therefore, the NUHOMS HSM design is in full compliance with the ACI 349-85 Code requirenents. Nevertheless, the concrete compressive strength and rebar yield stress given in Table $8.1-2$ at $500^{\circ} \mathrm{F}$ were used in calculating the concrete section capacities for the $125^{\circ}$ extreme off-normal and accident load cases to provide a conservative result. The conservatism on the concrete properties and temperatures which meet the ACI 349-85 requirements eliminates the need for surveillance inspection of the interior concrete surfaces following DSC emplacement.

NUH -003

D. 1-4

Revision 1 
WHC-SD-FF-DRR-00018

Rev. 0

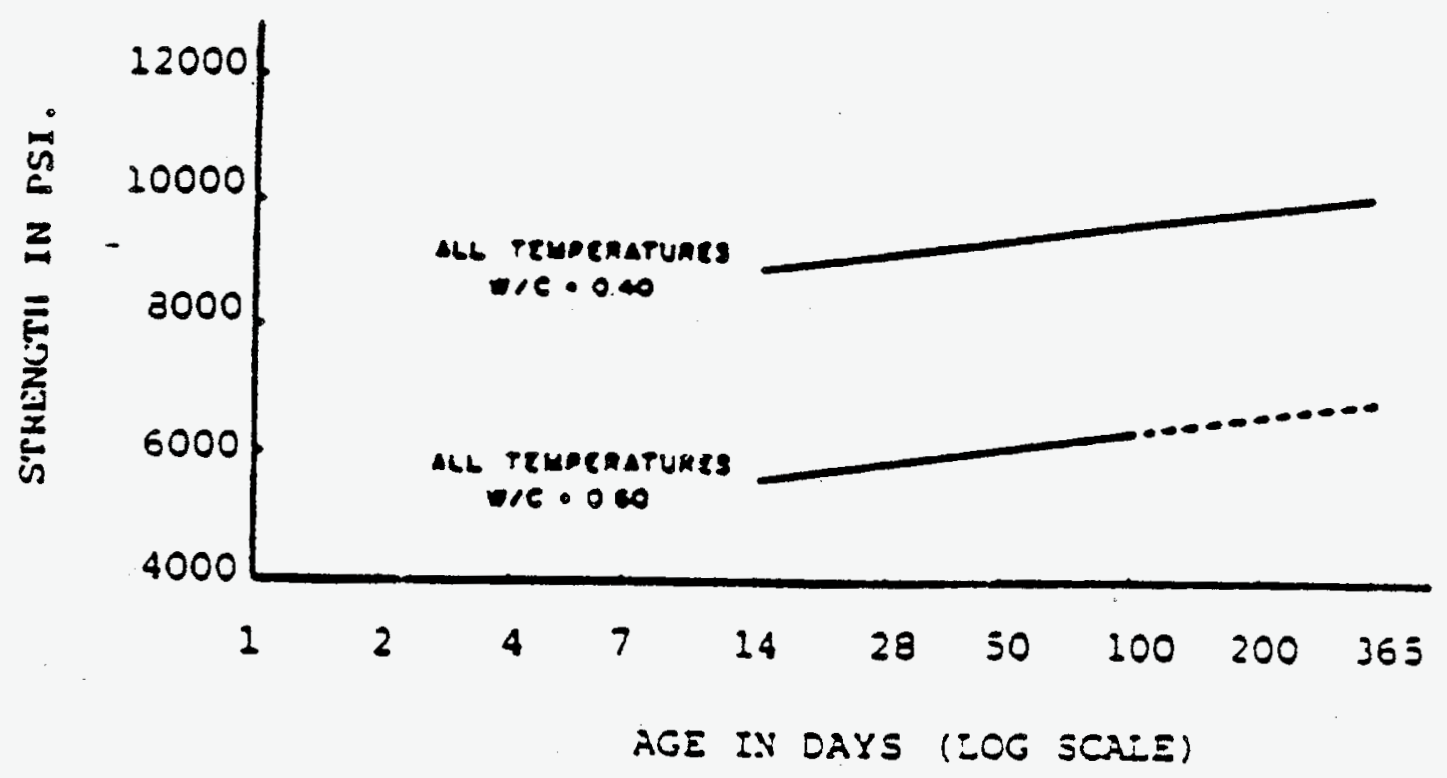

$($ Ref. D. T)

Figure $0.1-1$

Strength ys Age in Days liog scalel for $W / C$ Ratios of 0,40 and 0.60 at all Temeratures us to $205^{\circ} \mathrm{F}$

NUK-003

Revision 1

$$
\text { D. } 1-5
$$


WHC-SD-FF-DRR-00018

Rev. 0

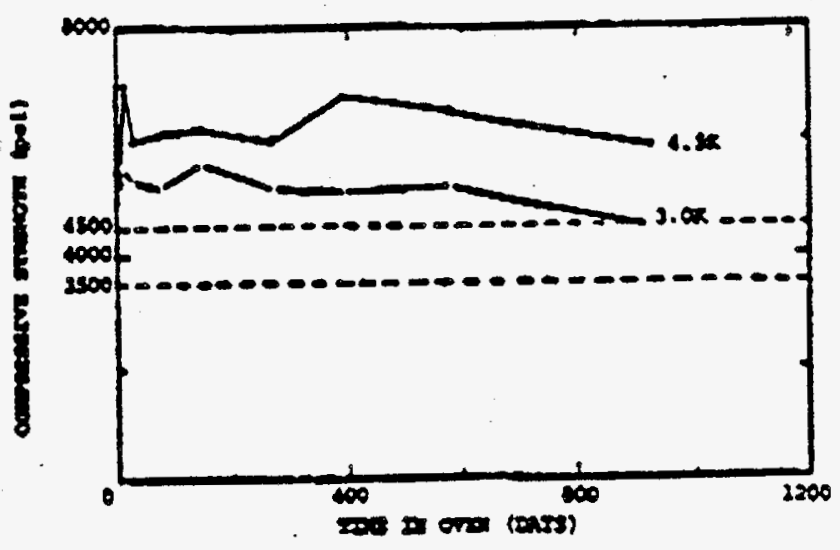

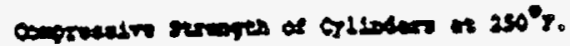

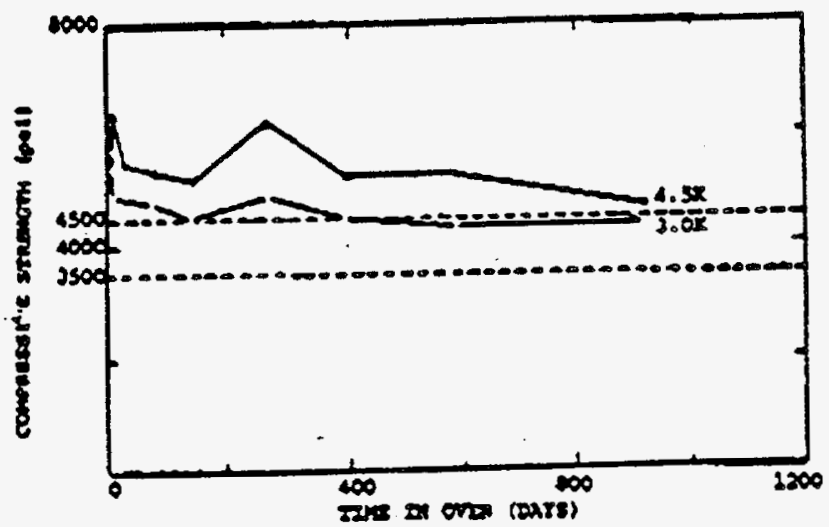

copresuiv serengeh of oyllosers at $390^{\circ} \mathrm{z}$.

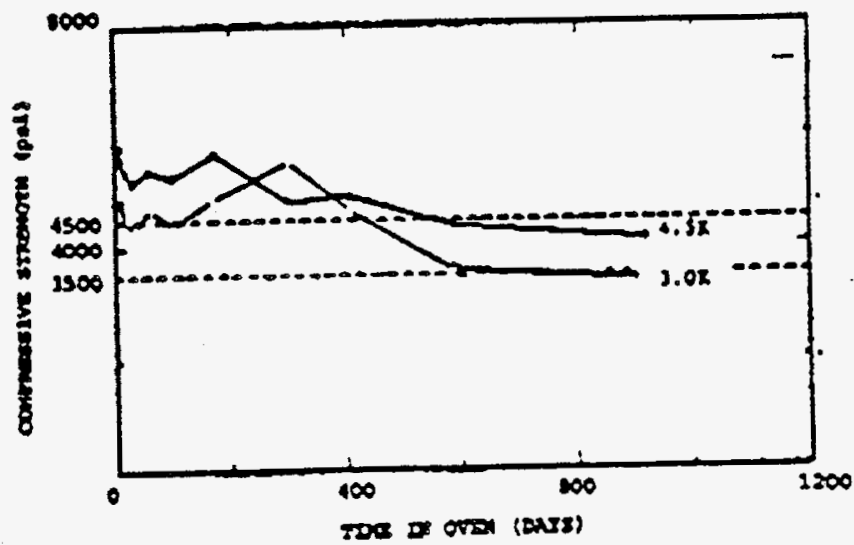

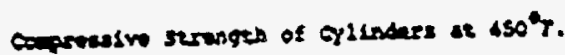

(Ref. 0.8 )

E1gure D.1-2

Concrate Comeressive strength at Various Temperatures 
WHC-SD-FF-DRR-00018

Rev. 0

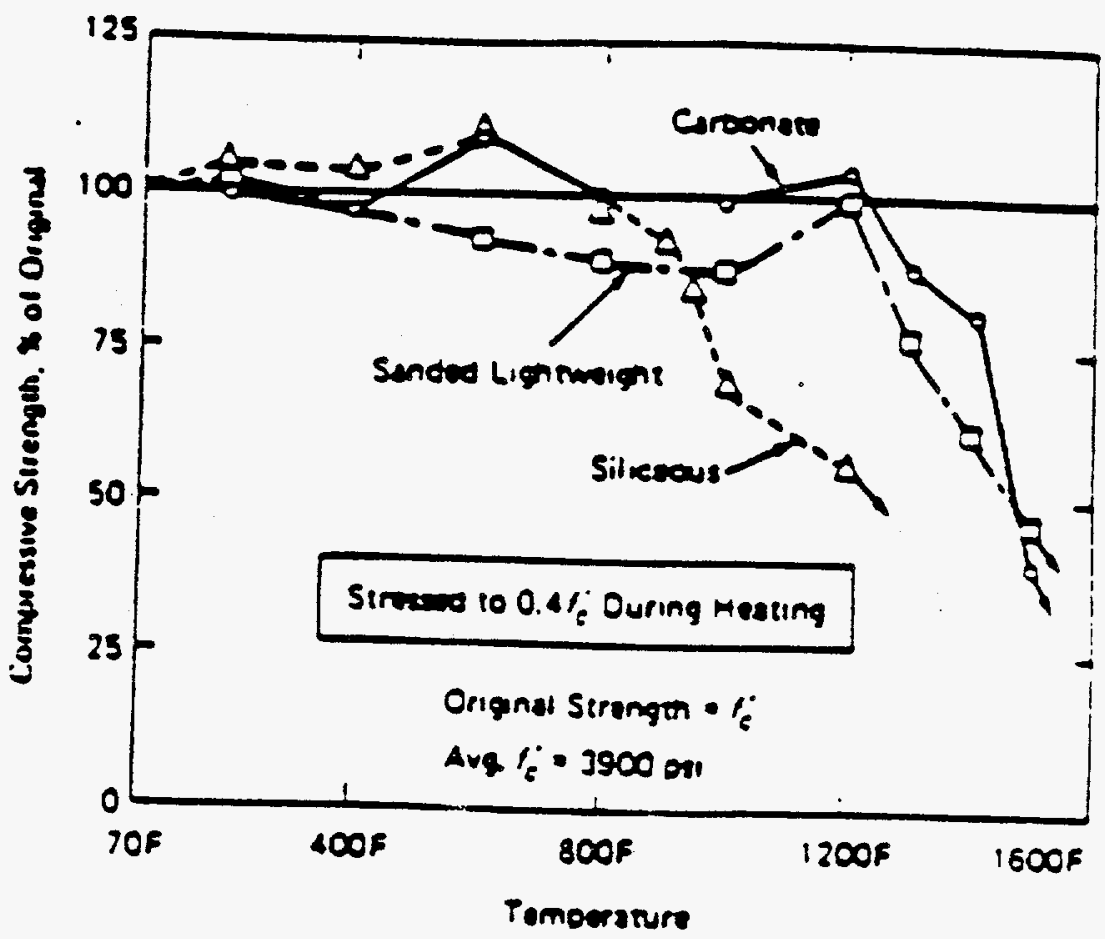

(Ref. D.2)

Figure $0.1-3$

compressive strength of concrete at high Temperatures

NUH -003

Revision 1

D. 1-7

A $8-58$ 

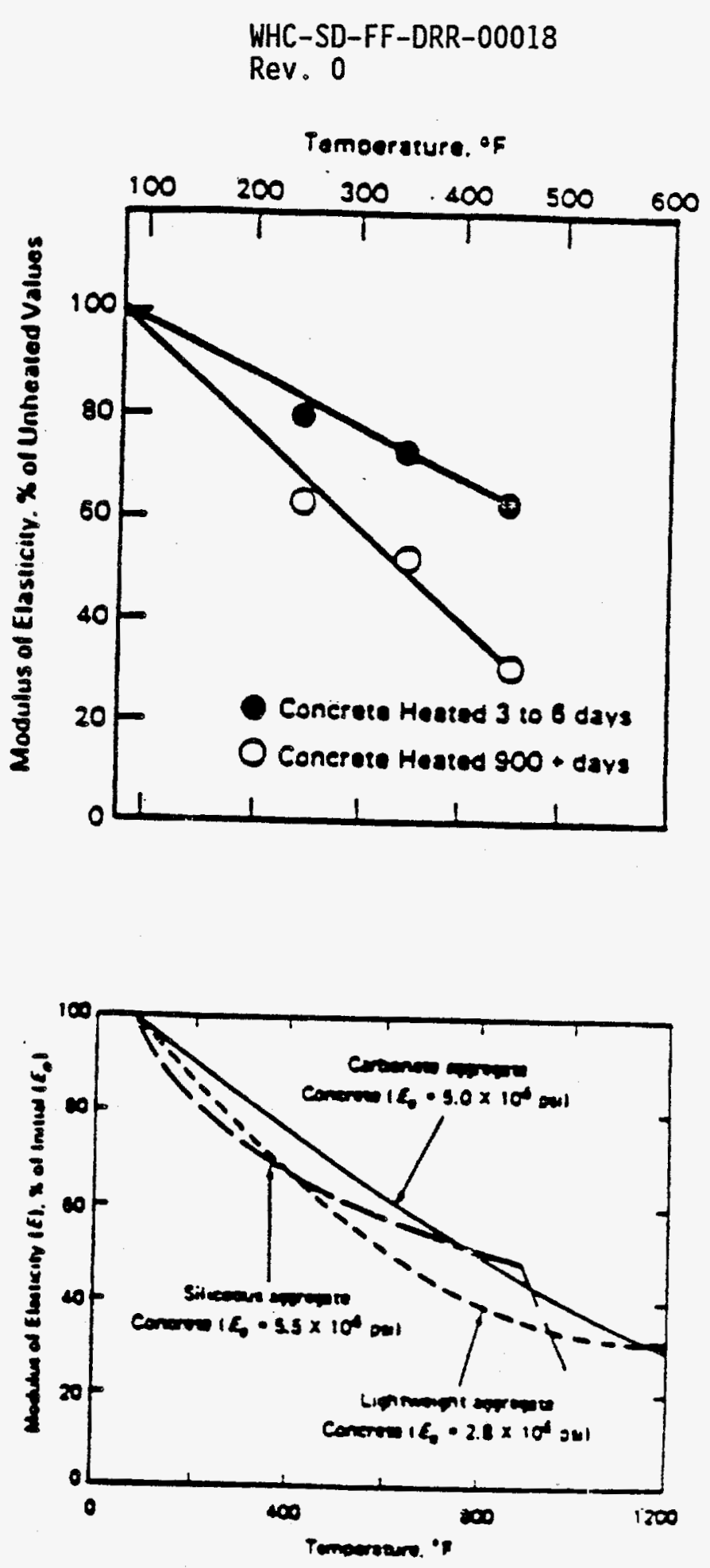

(Ref. D. 3)

Figure D.1-4

Modulus of Fiasticity of concrete at High Iemperatures

$\mathrm{NUH}-003$

Revision 1

D. 1-8

A8- 59 
WHC-SD-FF-DRR-00018

Rev. 0

D. 1 References

D. 1 N. G. Zoldners: Thermal properties of concrete Under Sustained Elevated remperatures, ACI Publication, paper SP25-1, American Concrete Institute, Detroit, MI (1970).

D.2 H. Fintel, Handbook of concrete Enqineering, Van Nostrand Reinhold Co., New York, N.Y., (1974).

D.3 M. S. Abrams, M. P. Gillen, and D. H. Campbell, Elastic and Strength Properties of Hanford concrete Kixes at Room and Elevated Temperatures, Construction Technologies Laboratories, Portland Cement Association, Skokie, Il (1979).

D.4 D. R. Lankard et al." Effects of Mojsture content on the Structural Properties of portland cement concrete Exposed to Temperatures Up to $500^{\circ} \Sigma$, ACI Special Publication, SP25, American Concrete Institute, Detroit, MI (1970).

D.5 R. D. Allen, High Temperature Properties of Concrete Relevant to Monitored Retrievable storage Application, Battelle, Pacific Northwest Laboratories (1984).

D.6 V. V. Bertero, M. Polvika, Influence of Thermal Exposures on Mechanical characteristies of concrete, ACI special Publication, SP.34, Concrete for Nuclear Reactors volume 1, American Concrete Institute, Detroit, MI (1972).

D.7 K. W. Nasser, greep of Concrete at Low Stress Strength Ratios and Elevated Temperatures, ACI Special Publication SP25, American Concrete Institute, Detroit, MI (1970).

D.8 Rockwell International, Effect of Long-Term Exposure to Elevated Temperature on the Mechanical Properties of Hanford Concrete, Construction Technology Laboratories, Portland Cement Association Report RHO-C-54.

D.9 T. Kanazu, et al, Hechanical Behavior of Concrete and Reinforced concrete at Elevated Tepperature Up to $500^{\circ} \mathrm{C}$, Transactions of the 8 th International conference on Structural Mechanics in Reactor Technology (SMiRT), Volume H, North-Holland for CEC (1985).

D. 10 A. Weber, G. Becker, Effects of Long Term Exposure on the Behavior of HTR Concrete, Transactions of the $8 \mathrm{th}$ International Conference on Structural Kechanics in Reactor Technology, Volume H, North-Holland for CEC (1985).

NUH-003

D. 2-1

Revision 1 